\title{
Pontifícia Universidade Católica

Daniel Milagres Nascimento

Entre Muros, Restos e Furos: errâncias como prática de atualização no dispositivo muro do ramal ferroviário Santa Cruz - Rio de Janeiro

\section{Dissertação de Mestrado}

Dissertação de Mestrado apresentada como requisito parcial para obtenção do grau de Mestre pelo Programa de Pós-Graduação em Arquitetura do Departamento de Arquitetura e Urbanismo da PUC-Rio.

Orientador: Prof. Marcos Favero 


\section{Pontifícia Universidade Católica $_{\text {a }}$

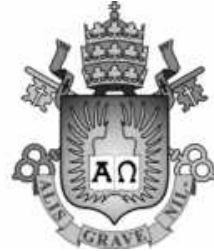

Daniel Milagres Nascimento

Entre Muros, Restos e Furos: errâncias como prática de atualização no dispositivo muro do ramal ferroviário Santa Cruz - Rio de Janeiro

Dissertação apresentada ao Programa de PósGraduação em Arquitetura da PUC-Rio como requisito parcial para a obtenção do grau de Mestre em Arquitetura. Aprovada pela Comissão Examinadora abaixo assinada.

\section{Prof. Marcos Favero} Orientador Departamento de Arquitetura e Urbanismo - PUC-Rio

Prof. João Masao Kamita Departamento de História e PPGArq - PUC-Rio

Profa. Fabíola do Valle Zonno UFRJ

Prof. Michel Nunes Lopes Masson Departamento de Arquitetura e Urbanismo - PUC-Rio

Profa $^{a}$. Monah Winograd

Coordenadora Setorial do Centro de Teologia e Ciências Humanas

Rio de Janeiro, 30 de agosto de 2018 
Todos os direitos reservados. É proibida a reprodução total ou parcial do trabalho sem a autorização da universidade, do autor e do orientador.

Daniel Milagres Nascimento

Graduou-se em Arquitetura e Urbanismo na PUC-Rio (2012). Tem extensão acadêmica na Universidade Técnica de Lisboa.

Ficha Catalográfica

Nascimento, Daniel Milagres

Entre muros, restos e furos : errâncias como prática de atualização no dispositivo muro do ramal ferroviário Santa Cruz - Rio de Janeiro / Daniel Milagres Nascimento ; orientador: Marcos Favero. - 2018.

128 f. : il. ; $30 \mathrm{~cm}$

Dissertação (mestrado)-Pontifícia Universidade Católica do Rio de Janeiro, Departamento de Arquitetura e Urbanismo, 2018.

Inclui bibliografia

1. Arquitetura - Teses. 2. Arquitetura e Urbanismo - Teses. 3. Muro. 4. Dispositivo. 5. Errância urbana. 6. Condição entre. 7. Ramal ferroviário Santa Cruz. I. Favero, Marcos. II. Pontifícia Universidade Católica do Rio de Janeiro. Departamento de Arquitetura e Urbanismo. III. Título. 


\section{Agradecimentos}

A Exu, por abrir e proteger todos os meus caminhos.

Ao meu orientador Professor Doutor Marcos Favero pelas conversas preciosas e pela leitura atenciosa deste trabalho.

À PUC-Rio pelos auxílios concedidos, sem os quais este trabalho não poderia ter sido realizado.

Aos Professores Doutores Fabíola do Valle Zonno, João Masao Kamita e Michel Masson, participantes na banca intermediária e final, pelas contribuições valiosas para o crescimento deste trabalho e por todo o apoio.

A minha mãe e meu pai, Tereza e Orlando, e à minha irmã, Mariana, por todo incentivo, sustentação e amor incondicional.

A Leandro Cunha por seu amor, por sua escuta preciosa, por sonhar e percorrer junto comigo todos os caminhos deste trabalho.

À minha amiga Professora Flaviana Raynaud pelas contribuições valiosas, pela leitura das narrativas, pelo incentivo e pelo carinho em todas as horas.

Às amigas de mestrado Laura Rosenbusch, Manuela Müller e Marina Piquet, por todas as trocas instigantes, apoio e incentivo ao longo deste percurso.

À mãe Carmem, por sua fé, seu amor e seu apoio inabaláveis.

A todos os meus amigos pelo incentivo, afeto e amor de sempre.

A Oxóssi e a Iansã, por tudo. 


\section{Resumo}

Daniel Nascimento, Daniel. Marcos Favero, Marcos (Orientador). Entre Muros, Restos e Furos: errâncias como prática de atualização no dispositivo muro do ramal ferroviário Santa Cruz - Rio de Janeiro. Rio de Janeiro, 2018. 128p. Dissertação de Mestrado - Departamento de Arquitetura e Urbanismo, Pontifícia Universidade Católica do Rio de Janeiro.

A pesquisa "Entre Muros, Restos e Furos" busca discutir a atualização no dispositivo muro do ramal ferroviário Santa Cruz no Rio de Janeiro através da realização de errâncias urbanas. O trabalho parte de certa invisibilidade deste dispositivo urbano, entendendo esta invisibilidade como resultado de seu processo histórico de estratificação. A prática de errâncias emerge como via possível de atualização neste dispositivo, na medida em que se constitui como experiência corporal de alteridade agindo, portanto, em uma condição estética específica, uma condição Entre. Ao desemaranhar este dispositivo por meio de três linhas de relações estabelecidas nesta investigação - Muros, Restos e Furos -, o trabalho discute modos de operar conceitualmente e empiricamente que podem arrastá-las de suas estratificações para suas atualizações. Assim, serão desenvolvidas narrativas de experiências, como escritas afetivas, de errâncias realizadas ao longo de três trechos do ramal ferroviário Santa Cruz: Engenho de Dentro, Engenho Novo e Encantado. Estas narrativas expõem Muros, Restos e Furos desdobrando reflexões acerca da potência estética e crítica das errâncias para a discussão sobre dispositivos urbanos e de condições Entre na cidade contemporânea.

\section{Palavras-chave}

Muro; dispositivo; errância urbana; condição entre; ramal ferroviário Santa Cruz; Rio de Janeiro. 


\section{Abstract}

Daniel Nascimento, Daniel. Marcos Favero, Marcos (Advisor). InBetween Walls, Rests and Holes: wanderings as actualizing practice in the wall dispositif of railway branch Santa Cruz - Rio de Janeiro. Rio de Janeiro, 2018. 128p. Dissertação de Mestrado - Departamento de Arquitetura e Urbanismo, Pontifícia Universidade Católica do Rio de Janeiro.

The research "In-Between Walls, Rests and Holes" seeks to discuss the actualization in the wall dispositif of the Santa Cruz railway branch in Rio de Janeiro through the realization of urban wanderings. The work starts from certain invisibility of this urban dispositif, understanding it as a result of its historical process of stratification. The practice of wanderings emerges as a possible way of actualizing this dispositif, inasmuch as it constitutes a body experience of alterity and therefore acts in a specific aesthetical condition, an "In-Between" condition. Untangling this dispositif through three lines of relationships established in this research - Walls, Rests and Holes -, this work discusses which modes of operation can conceptually and empirically drag them from their stratifications to their actualizations. Thus, narratives of the experiences will be developed as affective writings of wanderings carried out along three parts of the Santa Cruz railway branch: Engenho de Dentro, Engenho Novo and Encantado. These narratives, expose Walls, Rests and Holes unfolding reflections to the aesthetical and critical potenciality of the wanderings to the discussion about urban dispositifs and "In-Between" conditions in the contemporary city.

\section{Keywords}

Wall; dispositif; urban wanderings; in-between condition; wanderings; Santa Cruz railways branch; Rio de Janeiro. 


\section{Sumário}

1. Introdução: atualizar no dispositivo muro 11

2. Muros 20

2.1. Aberto para o estranhamento 20

2.2. Do caminhar entre o deambular: embaçando limites 27

2.3. Muros do Estranho: atualizações no Engenho de Dentro 35

3. Restos 46

3.1. Atento à sobrevivências 46

3.2. Do deambular entre o derivar: ativando restos 52

3.3. Restos sobreviventes: atualizações no Engenho Novo 61

4. Furos $\quad 81$

4.1. Imerso em encruzilhadas $\quad 81$

4.2. Do derivar entre o transurbar: encantando furos 88

4.3. Furos de Encruzilhada: atualizações no Encantado 94

5. Considerações Finais: sobre a condição Entre 110

6. Referências bibliográficas 115

7. Anexo: outros fragmentos errantes 119 


\section{Lista de Figuras}

Figura 1. Deambulação ao longo dos muros do ramal ferroviário Santa Cruz. Engenho de Dentro, Rio de Janeiro.

Figura 2. Muros no Engenho de Dentro, Rio de Janeiro. 21

Figura 3. Muros no Engenho de Dentro, Rio de Janeiro. 21

Figura 4. Muros no Rocha, Rio de Janeiro. 22

Figura 5. Muros em Quintino, Rio de Janeiro. 22

Figura 6. Deambular no meio. Engenho de Dentro, Rio de Janeiro. $\quad 35$

Figura 7. Deambulação e fluxos. Engenho de Dentro, Rio de Janeiro. 37

Figura 8. Deambulação na terceira margem. Engenho de Dentro, Rio de Janeiro. $\quad 40$

Figura 9. Cascas do deambular. Engenho de Dentro, Rio de Janeiro. 42

Figura 10. Deambulação e o ventre. Engenho de Dentro, Rio de Janeiro.

Figura 11. Movimentos do deambular. Engenho de Dentro, Rio de Janeiro.

Figura 12. Deriva entre muros e trilhos do ramal ferroviário Santa Cruz. Engenho Novo, Rio de Janeiro. 46

Figura 13. Restos em Deodoro, Rio de Janeiro. 48

Figura 14. Restos em Madureira, Rio de Janeiro. 48

Figura 15. Restos em Magalhães Bastos, Rio de Janeiro. 49

Figura 16. Restos em Bangu, Rio de Janeiro. 49

Figura 17. The Naked city, illustration de l'hypothése des plaques tournantes de Guy Debord, 1957.

Figura 18. Map of Venise de Ralph Rumney, 1957.

Figura 19. Derivar no meio. Engenho Novo, Rio de Janeiro. 61

Figura 20. Vergalhões. Engenho Novo, Rio de Janeiro. 64 
Figura 21. Guarda-chuva. Engenho Novo, Rio de Janeiro.

Figura 22. Escurecendo o chão. Engenho Novo, Rio de Janeiro. 66

Figura 23. Saco plástico. Engenho Novo, Rio de Janeiro. 66

Figura 24. Estruturas de madeira, Engenho Novo, Rio de Janeiro. $\quad 68$

Figura 25. Embalagem de Coca-cola, Engenho Novo, Rio de Janeiro. 69

Figura 26. Tênis, Engenho Novo, Rio de Janeiro. 70

Figura 27. Garrafa de Pepsi, Engenho Novo, Rio de Janeiro. 71

Figura 28. Copos e garrafas de vidro, Engenho Novo, Rio de Janeiro. 72

Figura 29. Cabo de borracha, Engenho Novo, Rio de Janeiro. 73

Figura 30. Produzindo vibrações, Engenho Novo, Rio de Janeiro. 74

Figura 31. Jornal, Engenho Novo, Rio de Janeiro. 75

Figura 32. Cacos de louça, Engenho Novo, Rio de Janeiro. 76

Figura 33. Vaso de louça, Engenho Novo, Rio de Janeiro. 76

Figura 34. Piso antiderrapante, Engenho Novo, Rio de Janeiro. 77

Figura 35. Palmilha, Engenho Novo, Rio de Janeiro. 78

Figura 36. Descobrindo os pés, Engenho Novo, Rio de Janeiro. 79

Figura 37. Homem carregando vassouras, Engenho Novo,

Rio de Janeiro.

Figura 38. Transurbância através dos muros do ramal ferroviário Santa Cruz, Encantado, Rio de Janeiro. 81

Figura 39. Furo de passagem em Magalhães Bastos, Rio de Janeiro. 82

Figura 40. Furo em Campo Grande, Rio de Janeiro. 83

Figura 41. Furo em Santíssimo, Rio de Janeiro. 83

Figura 42. Furo em Senador Camará, Rio de Janeiro. 84

Figura 43. Mapa da ação "Stalkers através dos territórios atuais" realizada pelo grupo Stalker $\quad 89$

Figura 44. Transurbar no meio, Encantado, Rio de Janeiro. 94 
Figura 45. Alianças de apoio no transurbar, Encantado, Rio de Janeiro. 95 Figura 46. Produzir o vazio no transurbar, Encantado, Rio de Janeiro. 97 Figura 47. Vertigem no transurbar, Encantado, Rio de Janeiro. 98 Figura 48. Embolando falas no transurbar, Encantado, Rio de Janeiro. 99 Figura 49. Experimentando desequilíbrios, Encantado, Rio de Janeiro. 100 Figura 50. Lançando o corpo no vazio, Encantado, Rio de Janeiro. 101 Figura 51. Imitando os estratos do muro, Encantado, Rio de Janeiro. 102 Figura 52. Seguindo o fluxo da rua, Encantado, Rio de Janeiro. 103 Figura 53. Produzindo uma síncope, Encantado, Rio de Janeiro. 104 Figura 54. Símbolo da errância [Ka], Encantado, Rio de Janeiro. 105 Figura 55. Arriscando outros ritmos, Encantado, Rio de Janeiro. 106 Figura 56. Palavras ao vento, Encantado, Rio de Janeiro. 106 Figura 57. Fluxos à pele, Encantado, Rio de Janeiro. 108 Figura 58. Salto no ar, Encantado, Rio de Janeiro. 109 


\section{Introdução: atualizar no dispositivo muro}

Reproduzir implica a permanência de um ponto de vista fixo, exterior ao reproduzido: ver fluir, estando na margem. Mas seguir é coisa diferente do ideal de reprodução. Não melhor, porém outra coisa. Somos de fato forçados a seguir quando estamos à procura de "singularidades" de uma matéria ou, de preferência, de um material, e não tentando descobrir uma forma (DELEUZE; GUATTARI, 2012, p. 42).

As caminhadas que realizo cotidianamente para alcançar a estação do Engenho de Dentro, seja para iniciar ou terminar os deslocamentos pela ferrovia, são sofridas. Em qualquer horário do dia, algo de árido entra em cena quando caminho por ali. A escassez de cruzamentos ao longo destas margens ferroviárias - fato cotidiano - se reflete internamente como uma escassez de escolhas e de possibilidades que beiram à ausência.

A estação inexoravelmente configura-se como referência de cruzamento e é o guia de meu desejo de movimento. Entretanto, incômodo é o caminho até lá. $\mathrm{Na}$ busca de um maior entendimento sobre esta sensação tão presente nestas margens ferroviárias, surgem, pela primeira vez, os muros que conformam os seus limites. Eles materializam-se quase como confessionários de todo o incômodo que me é gerado ao passar pelos ambientes que se desenvolvem ao longo destas margens - tão características - do subúrbio carioca, porém sendo, ao mesmo tempo, praticamente invisíveis.

Mais do que sua aparência, seu poder psicológico e energético foi preponderante na construção da minha experiência nestas margens. A sensação é de total estranhamento. Familiares e, ao mesmo tempo, estranhos, os muros apareceram. A certeza de que eles têm este poder de influência direta em minha experiência com estas margens ferroviárias e mesmo assim se abstiveram de sua visualidade é, repito, a de estranhamento integral. Parece-me desafiador realizar aqui o movimento contrário, isto é, lê-los e ouvi-los partindo do que me perturba, do que está fora de minha zona de conforto perceptiva, do que ainda não conheço integralmente.

É partindo deste estranhamento frente a este muro que guarda um alto grau de "expectância", como se estivesse à espera de outros desvelamentos, que 
pretendo traçar uma discussão relativa à construção de narrativas a partir de errâncias e sua potência de atualização deste muro enquanto dispositivo urbano. Nesta construção singular ao longo do ramal ferroviário Santa Cruz no Rio de Janeiro - entre estações de parada -, foram mobilizados afetos que construíram relações de alteridade entre corpo e cidade que mostram possibilidades de engendrar outras leituras para este muro e, assim, gerar reflexão sobre a cidade.

$\mathrm{O}$ fato de viver no subúrbio e conviver diariamente com a presença do ramal ferroviário Santa Cruz é fundamental para se entender a posição a partir da qual este trabalho se inicia. A cidade que acontece próxima a estes limites da ferrovia, cruzando diversas zonas suburbanas do Rio de Janeiro, é, pessoalmente, familiar. A presença da ferrovia, para muitos, tornou-se um fator limitador para o caminhar dentro dos bairros, principalmente quando construiu os muros em suas margens e gerou estes limites, estas barreiras aparentemente intransponíveis. Este fato influenciou diretamente nas dinâmicas socioeconômicas e culturais e, consequentemente, na circulação de pessoas por estes locais que têm, em sua maioria, vias de transporte rodoviário os acompanhando lateralmente.

Como resultado deste processo, identifico que foi construída certa invisibilidade destes muros em relação à discussão sobre dispositivos urbanos, fenômeno que se confirma na minha experiência como morador da área. $\mathrm{O}$ fato de entendê-los, no senso comum, como parte intrínseca à ferrovia, associa-os exclusivamente ao discurso da necessidade de controle e segurança dos fluxos de pessoas nestas margens, não negado neste trabalho, mas que, inegavelmente, produz relações de afastamento, de medo, de insegurança e de aridez que são, por fim, desdobradas em uma sensação de invisibilidade.

Ao reconhecer isto, flagrei a urgência de se pensar, de forma mais cuidadosa, sobre este elemento tão definidor das dinâmicas nestes trechos que margeiam o segundo ramal ferroviário mais longo (aproximadamente $60 \mathrm{~km}$ ), com maior circulação de pessoas no Rio de Janeiro e, ao mesmo tempo tão ausente nas discussões sobre a cidade. Como seria possível construir outras formas de apreender e compreender estes muros?

Pareceu-me inevitável me aproximar do entendimento deste muro como dispositivo. Ele é mediador da experiência corporal tanto nas áreas extramuros, onde se pode oficialmente caminhar, quanto nas intramuros, que entendo aqui, através da discussão de Ignasi Solà-Morales, como terrain vagues. Eles impedem, 
filtram e permitem que relações sejam estabelecidas. Para tanto, aproximei-me de Michel Foucault, que trabalha este conceito de dispositivo quando vai pensar as relações entre "Saber", "Poder" e os "processos de subjetivação" em prisões. As prisões operam como dispositivos que, segundo ele, configuram-se como:

Um conjunto decididamente heterogêneo, que engloba discursos, instituições, organizações arquitetônicas, decisões regulamentares, leis, medidas administrativas, enunciados científicos, proposições filosóficas, morais, filantrópicas. Em suma, o dito e o não dito são os elementos do dispositivo. O dispositivo é a rede que se pode tecer entre estes elementos (FOUCAULT, 2000, p. 244).

Gilles Deleuze, já nos anos 1970, atualiza a discussão iniciada por Foucault sobre esta noção e diz:

Mas o que é um dispositivo? Em primeiro lugar, é uma espécie de novelo ou meada, um conjunto multilinear. É composto por linhas de natureza diferente e essas linhas do dispositivo não abarcam, nem delimitam sistemas homogêneos por sua própria conta, mas seguem em direções diferentes, formam processos sempre em desequilíbrio, e essas linhas tanto se aproximam quanto se afastam uma das outras [...] Desemaranhar as linhas de um dispositivo é, em cada caso, traçar um mapa, cartografar, percorrer terras desconhecidas [...] (DELEUZE, publicação eletrônica)

O muro é entendido aqui como dispositivo que, assim como o novelo descrito por Deleuze, constrói e é construído por um emaranhamento de linhas ligadas às três dimensões foucaultianas (Saber, Poder, Subjetividade), sendo suas principais: (1) as de visibilidade, que constroem, a partir de seus regimes de visibilidade, formas de ver e não ver; (2) as de enunciação, que compõem, a partir de seus regimes de enunciação, formas de falar e não falar - duas linhas que constituem formas do "Saber" no dispositivo; (3) as de força, que são indistinguíveis das duas primeiras, atravessando-as e, assim, construindo o que se pode e não pode, constituindo formas de "Poder" no dispositivo; (4) as de subjetividade, que são as linhas ligadas aos processos de subjetivação que acontecem no dispositivo, vinculando-se, assim, a dimensão da "Subjetividade".

Entendendo um pouco melhor de sua estrutura, as linhas que compõem um dispositivo são entendidas como "vetores" ou "tensores", pois não possuem contornos definitivos "são antes cadeias de variáveis relacionadas entre si" (DELEUZE, publicação eletrônica). Este aspecto permite pensar que alterando a minha posição, historicamente estabelecida, de afastamento com relação a este muro, é possível gerar outras formas de apreendê-lo e compreendê-lo. 
Sobre esta mudança de posição, há que se considerar dois outros aspectos fundamentais para esta investigação que dividem todas as linhas de qualquer dispositivo: (1) as linhas de estratificação ou sedimentação, ligadas àquilo que é a história, o "arquivo", o que se fala e se vê, historicamente, sobre tal dispositivo e, por esta razão, o que os separa de nós mesmos, pois assume uma condição fixa; (2) as linhas de atualização ou criatividade, que estão ligadas ao devir, ao atual, ao que atualiza este dispositivo, àquilo que faz com que tal linha se aproxime de nós mesmos, pois assume uma condição de movimento, de produção constante de diferença.

Neste sentido, entendo que as linhas de estratificação do dispositivo muro estão relacionadas com aquilo que atravessa a minha experiência cotidiana de morador destas margens ferroviárias, isto é, com a invisibilidade destes muros associada ao discurso que os entende enquanto parte do ramal ferroviário e necessários para o controle e segurança dos fluxos na cidade do Rio de Janeiro.

No entanto, é exatamente nas linhas de atualização em que encontro a possibilidade de produzir outras formas de "Saber" e de "Poder" no dispositivo muro, pois nelas há a produção do novo, do atual. Este atual "não é aquilo que somos, mas aquilo em que vamos nos tornando, o que chegamos a ser, o outro" (DELEUZE, publicação eletrônica) configurando, assim, a possibilidade de imergir nos devires que atravessam e constituem este muro, para além de sua concretude e de seu pertencimento à ferrovia. Atualizar no dispositivo muro.

O caminhar é a via escolhida de reposicionamento corporal e de imersão nos devires. Porém, um outro caminhar: a partir da leitura de Francesco Careri em Walkscapes: o caminhar como prática estética, e de Paola Berenstein Jacques, em Elogio aos Errantes, em que se discutem ações de caminhadas erráticas realizadas no campo da arte ao longo do século XX, entendo e pratico, nesta investigação, o caminhar não somente como leitura e escrita do território (CARERI, 2015), mas sobretudo como uma prática de apreensão e compreensão da cidade de intenso viés crítico, como errância urbana, conforme define Jacques (JACQUES, 2014).

A errância urbana "afirma-se como uma possibilidade de crítica, resistência ou insurgência contra a ideia de empobrecimento, perda ou destruição da experiência a partir da modernidade" (JACQUES, 2014, p. 27). Esta prática opera sobre as linhas de fuga nos dispositivos, isto é, operam no escape, no desvio às linhas de força que os constituem. Entendendo melhor este modo de operação, 
Jacques vincula a errância à noção de alteridade, aproximando o principio da diferença - que funda a noção de devir e atualização de Deleuze e Guattari:

[a experiência errática] como ferramenta, é um exercício de afastamento voluntário do lugar mais familiar e cotidiano, em busca de uma condição de estranhamento, em busca de uma alteridade radical. O errante vai de encontro à alteridade na cidade, ao Outro, aos vários outros, à diferença, aos vários diferentes (JACQUES, 2014, 31, grifo meu).

Assim, as errâncias urbanas, enquanto experiência de alteridade, estão diretamente ligadas ao que Michel De Certau chama em $A$ invenção do Cotidiano, de táticas desviatórias, como a busca por uma "ausência de poder", em contraposição às estratégias, que são organizadas pelo "postulado do poder" (CERTAU, 1998, p. 101). Jacques aponta três tipos de táticas em que as errâncias operam: (1) a desorientação, que é a experiência do perder-se; (2) a lentidão, que é a experiência de recusa ao tempo acelerado da cidade contemporânea; (3) a incorporação, que é a experiência de corporificação das energias e afetos que foram atravessados ao longo do percurso.

Esta prática urbana tem uma ligação direta com o que Deleuze e Guattari desenvolvem no Tratado de Nomadologia, sobre as relações entre o nomos e a polis, a máquina de guerra e o aparelho do Estado, o espaço liso dos nômades ao espaço estriado dos sedentários:

O espaço liso e o espaço estriado - o espaço nômade e o espaço sedentário [...] não são da mesma natureza. Por vezes podemos marcar uma oposição simples entre os dois tipos de espaço. Outras vezes devemos indicar uma diferença muito mais complexa, que faz com que os termos sucessivos das oposições consideradas não coincidam inteiramente. Outras vezes ainda devemos lembrar que os dois espaços só existem de fato graças às misturas entre si: o espaço liso não para de ser traduzido, transvertido num espaço estriado; o espaço estriado é constantemente revertido, devolvido a um espaço liso. (DELEUZE; GUATTARI, 2017, p. 192)

As errâncias são, portanto, entendidas como uma forma de "alisar" os espaços estriados gerados no dispositivo muro do ramal ferroviário Santa Cruz, na medida operam neste nomadismo, a partir destas táticas desviatórias. Isto é, as errâncias atuam sobre as linhas de fuga no dispositivo.

Partindo deste princípio, as errâncias serão aqui investigadas, realizadas e apresentadas através de narrativas que foram delas desdobradas. Em O Narrador, Walter Benjamin já apontava que o problema da realização destas experiências corporais urbanas não estaria propriamente em sua efetuação na cidade, mas 
sobretudo, em sua transmissão, na "faculdade de intercambiar experiências" (BENJAMIN, 2014, p. 213-214). Assim, as narrativas que foram construídas e serão apresentadas neste trabalho serão a forma de dar continuidade a este "alisamento" realizado nas errâncias ao longo dos muros do ramal, entendendo este lugar de narração como um lugar ocupado e não fixo, para, desta forma, produzir as atualizações no dispositivo muro.

Tendo em vista que esta investigação busca produzir outras formas de apreender e compreender este dispositivo urbano, os modos de errância que serão trabalhados parecem possibilitar uma abertura para a complexidade que a cidade e, especificamente neste caso, as margens do ramal ferroviário Santa Cruz podem apresentar. Tal busca acontecerá exatamente através da possibilidade que estas práticas engendram de imersão no movimento dos fluxos e forças do ambiente urbano, por meio da alteridade, permitindo que seus esvaecimentos, sobreposições, misturas (que mostram tais complexidades) construam outras leituras urbanas. Este processo, fundamental para esta investigação, opera na chave do que Deleuze e Guattari definem como uma condição Entre:

Entre as coisas não designa uma correlação localizável que vai de uma para outra e reciprocamente, mas uma direção perpendicular, um movimento transversal que carrega uma e outra, riacho sem início nem fim, que rói suas duas margens e adquire velocidade no meio. (DELEUZE; GUATTARI, 2017, p. 49, grifo meu)

O Entre, para os autores, é o meio. Meio como via de acesso às coisas e meio como espaço entre termos.

Imersos nesta condição deleuze/guattariana, cada modo de errância escolhido - deambulação, deriva e transurbância - terá seus "arrastamentos" localizados, ou seja, seus momentos de "erosão", que pressupõem atualização como forma de pensar para além das definições, apontando também suas zonas de instabilidade, de mistura, de indefinição entre cada um deles. Esta escolha acontece primeiramente por um reconhecimento pessoal de que não há, de fato, purismo nestas definições, pelo contrário, foram assumidas, historicamente, as suas influências e, em segundo lugar, por uma busca de dissolução de certa rigidez de fronteiras metodológicas em direção a um movimento de abertura ao afeto como fonte potente de crítica urbana, fator que parece imprescindível para se construir uma prática de atualização, que é o objetivo desta investigação. 
Entender as errâncias como práticas que reivindicam um tipo de experiência que tem se mostrado rara nas cidades contemporâneas, a de alteridade, é uma escolha de abrir-se para o acaso, para o desconhecido, para os acontecimentos que escapam nestes locais, mas que falam intensamente sobre os outros sentidos que este muro pode ganhar. Assim como Deleuze diz, "o acontecimento não é o que acontece (acidente), ele é no que acontece o puro expresso que nos dá sinal, e nos espera. [...] $\mathrm{O}$ brilho, o esplendor do acontecimento, é o sentido" (DELEUZE, 2011, p. 152).

Assim sendo, as narrativas que serão apresentadas são entendidas como aquilo que, ao acontecerem, podem fazer emergir outros sentidos, mais incorporados, que possam, através de sua capacidade de imergir nos fluxos da cidade, sair do registro do que os muros são para o que os muros podem devir.

Entendendo, assim, que o dispositivo muro do ramal ferroviário Santa Cruz é, neste trabalho, muito mais do que o elemento concreto muro, os três capítulos que, somados à introdução, às considerações finais e às referencias bibliográficas, compõem o corpo desta dissertação foram construídos a partir de experiências erráticas que para serem apresentadas foram desemaranhadas em três tipos de relação de alteridade estabelecida nele: (1) com os muros (2) com os restos (3) com os furos.

O capítulo 2, Muros, é montado a partir da seguinte questão: como o estranhamento produzido no corpo que deambula diante dos muros, dos limites, das fronteiras do ramal ferroviário Santa Cruz, pode atualizar o dispositivo muro? $\mathrm{Na}$ primeira seção do capítulo discuto sobre a condição de abertura ao estranhamento no ambiente urbano a partir de articulações teóricas de Deleuze/Guattari, Solà-Morales, Anthony Vidler e Sigmund Freud, na tentativa de refletir sobre o estranhamento como uma categoria estética que pode arrastar o muro de seu estriamento e estratificação para seu alisamento e atualização. $\mathrm{Na}$ segunda, investigo a deambulação, com seus arrastamentos do caminhar dadaísta, a partir de articulações teóricas engendradas sobre os surrealistas e o artista Flávio de Carvalho, a fim de refletir sobre a potência de uma errância movida, em sua dimensão estética, pelo estranhamento. Na última seção, apresentarei a narrativa da deambulação realizada no ramal ferroviário Santa Cruz, no trecho do bairro do Engenho de Dentro, desdobrando certo "murar", que chamo de Muros do Estranho, como atualização no dispositivo muro. 
O capítulo 3, Restos, tem como questão central: como o afeto, gerado pelas sobrevivências encontradas no corpo que deriva ao longo destes muros atualiza o dispositivo muro? Para traçar esta reflexão. aproximo-me inicialmente da discussão sobre as sobrevivências a partir de articulações teóricas de SolàMorales, Jacques, na tentativa de refletir sobre um outro "restar" e sobre sua potência para arrastar os estratos e estriamentos do dispositivo muro para possibilidades de alisamentos e atualizações. Na segunda seção, investigo a deriva, com seus arrastamentos da deambulação, a partir de articulações teóricas engendradas sobre os situacionistas e o artista Hélio Oiticica, a fim de pensar sobre a potência de encontro e ativação de sobrevivências que este tipo de errância possui. Na terceira seção, mostrarei uma narrativa da deriva realizada no ramal ferroviário Santa Cruz no trecho do bairro Engenho Novo, desdobrando certo "restar", que chamo, como atualização no dispositivo muro, de Restos sobreviventes.

O capítulo 4, Furos, é construído a partir da seguinte questão: como as encruzilhadas produzidas como furos do corpo que transurba nestes muros, pode atualizar o dispositivo muro? Na primeira seção, discuto sobre o movimento de imersão em síncopes e encruzilhadas a partir da aproximação teórica de Simas e Rufino dialogando com Solà-Morales e Deleuze/Guattari, na tentativa de refletir sobre como mover os furos engendrados no muro de seus estriamentos e estratificações para um outro "furar", movido pela abertura ao desconhecido, aos dribles e encantamentos. Na segunda, investigo a transurbância, com os arrastamentos entre o derivar e a prática de Transurbância a partir de articulações teóricas engendradas por Careri no grupo Stalker e atravessamentos com a obra Noticias de América, do artista Paulo Nazareth, a fim de pensar sobre a potência de encantamento de furos do espaço que esta errância guarda. Na última seção, apresentarei a narrativa da transurbância realizada no ramal ferroviário Santa Cruz, no trecho do bairro do Encantado, desdobrando certo "furar", que chamo de Furos de Encruzilhada, como atualizações no dispositivo muro.

As narrativas que serão apresentadas em cada capítulo foram realizadas como um acompanhamento do fluxo afetivo que se realizou nas errâncias, como escritas afetivas e poéticas.

Nas considerações finais, discutirei sobre como a atualização no dispositivo muro, através das errâncias, ajuda a tentar compreender o que seria 
uma condição Entre Muros, Restos e Furos nestas margens urbanas. Apontarei alguns desdobramentos para a reflexão sobre o lugar do narrador na relação com o dispositivo muro, assim como para algumas reverberações que o trabalho pode ter para pensar outros dispositivos e relações de complexidade produzidos pela condição Entre no corpo, cidade e paisagem contemporâneos.

Após estas considerações, reunirei alguns movimentos, ações, sobrevivências, sensações e percepções movidas por esta investigação como um convite aberto ao "perder-se" pelo mundo.

Em anexo, apresentarei um conjunto de fragmentos errantes com experiências de narrativa feitas a partir dos inúmeros percursos que realizei no ramal ferroviário Santa Cruz ao longo da construção deste trabalho. São experiências do meu processo de entrada em outros modos de escrita que, associados ao corpo principal deste trabalho, ampliam o que pode haver de singular e múltiplo neste percurso de investigação. 


\section{Muros}

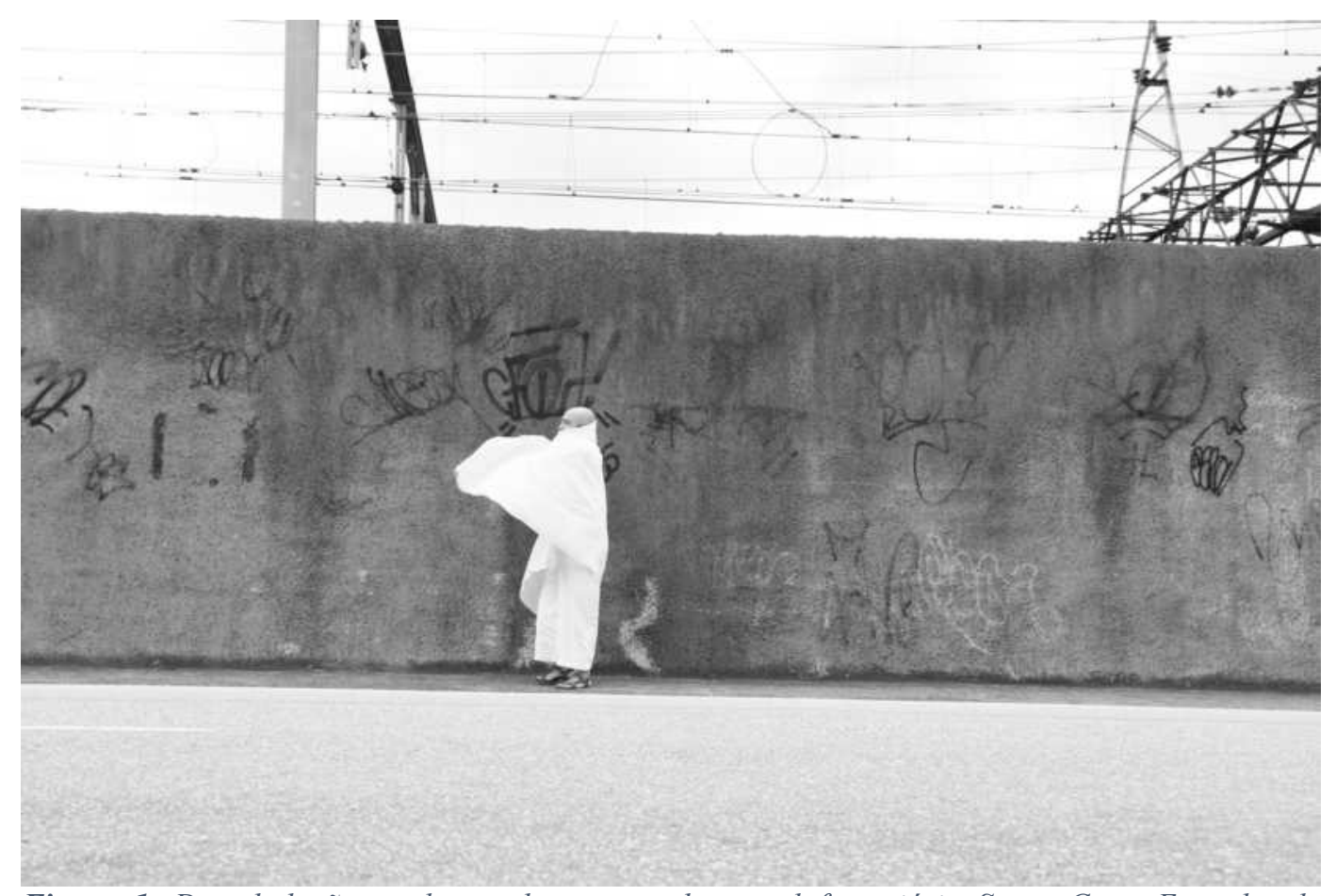

Figura 1. Deambulação ao longo dos muros do ramal ferroviário Santa Cruz. Engenho de Dentro, Rio de Janeiro.

O entusiasmo por esses espaços vazios, expectantes, imprecisos, flutuantes é, em código urbano, a resposta à nossa estranheza ante o mundo, ante a nossa cidade, ante nós mesmos (SOLÀ-MORALES, 2002, p. 191).

\subsection{Aberto para o estranhamento}

Os muros que margeiam o ramal ferroviário Santa Cruz começaram a ser construídos a partir de 1858 (ABREU, 2010, p. 50). O intuito era o impedimento da passagem de pedestres ao longo dos ramais ferroviários da cidade do Rio de Janeiro que passaram, neste período, do sistema operacional mecânico para o sistema elétrico, aumentando a velocidade dos trens e o risco de acidentes. Tal ação configurou limites claros nestas margens ferroviárias que, até a contemporaneidade, permanecem marcando estes locais. 


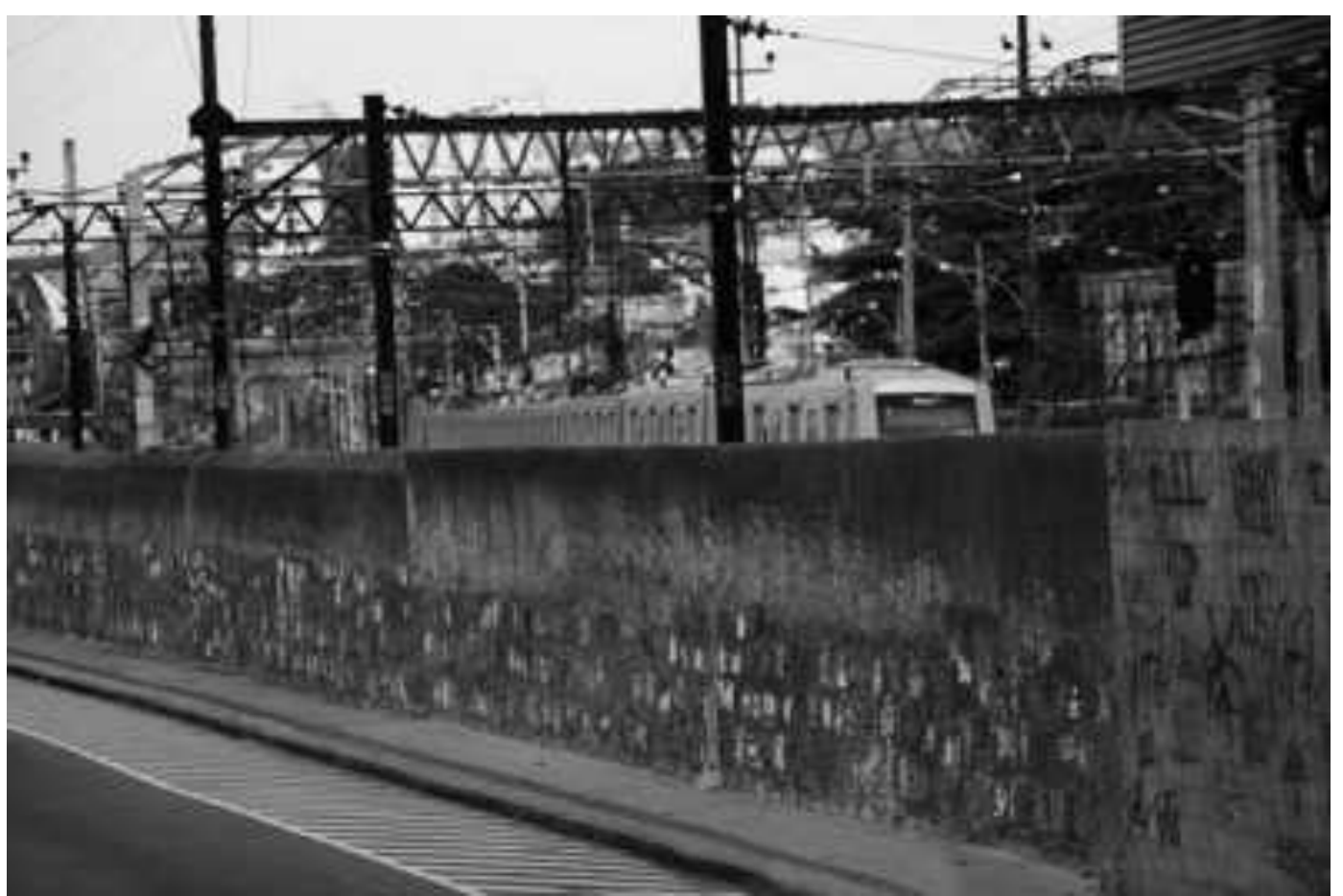

Figura 2. Muros no Engenho de Dentro, Rio de Janeiro.

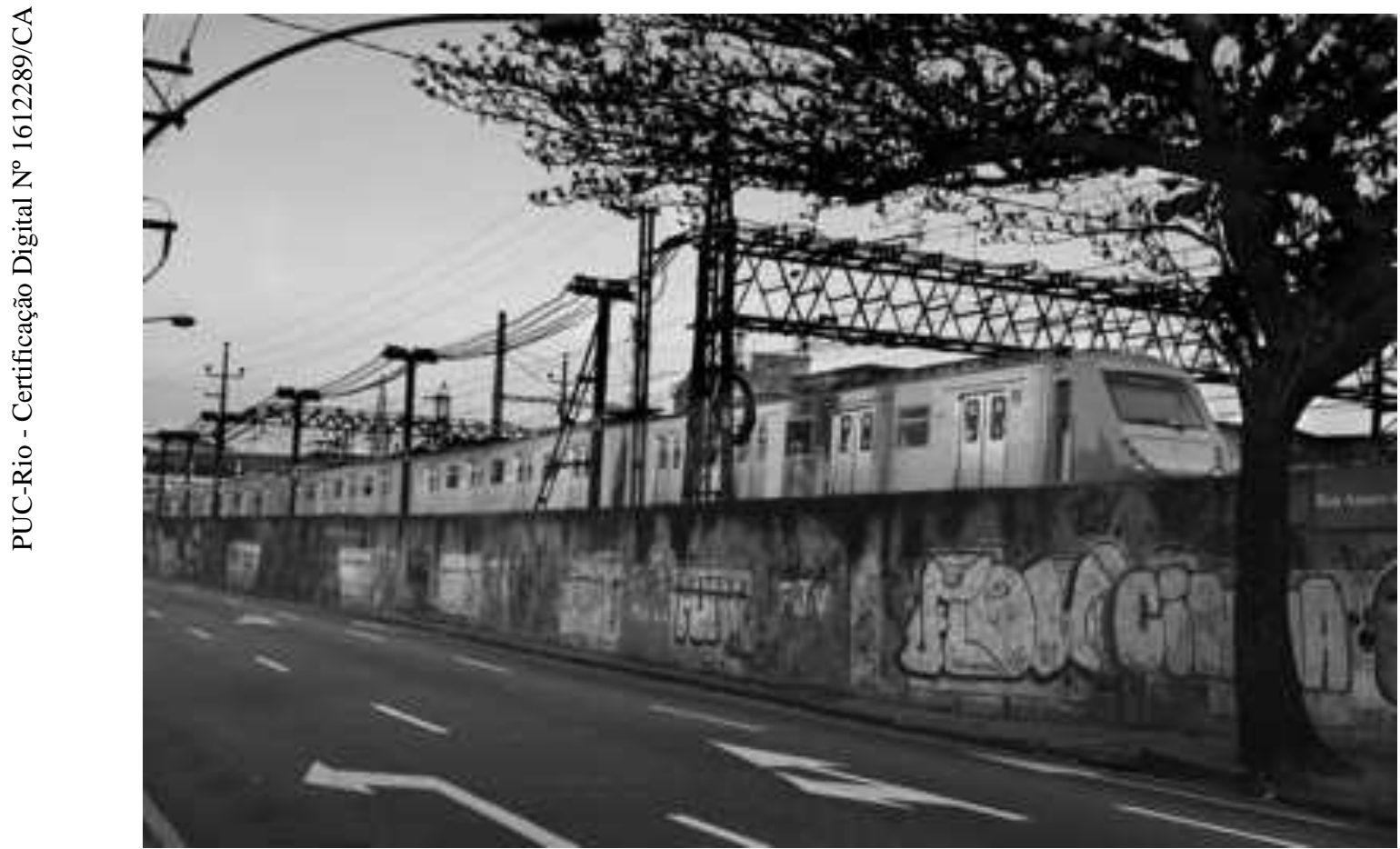

Figura 3. Muros no Engenho de Dentro, Rio de Janeiro. 


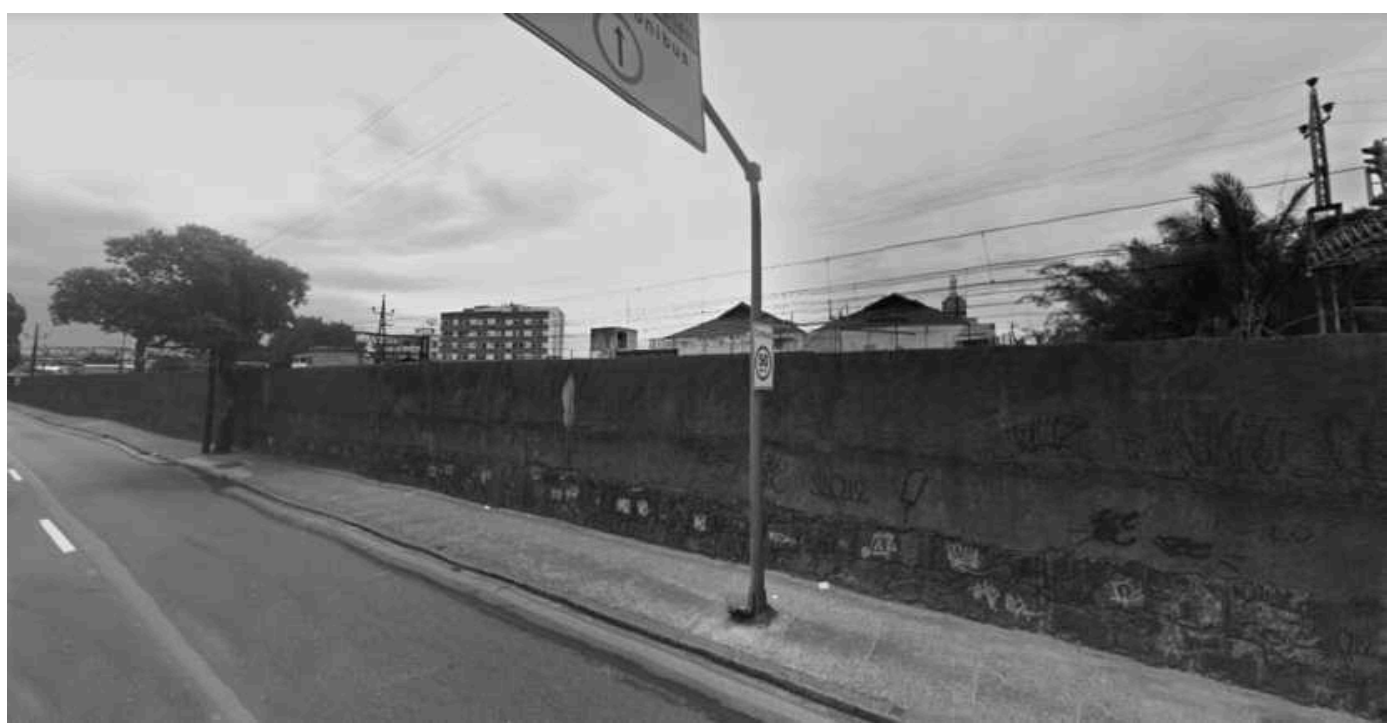

Figura 4. Muros no Rocha, Rio de Janeiro.

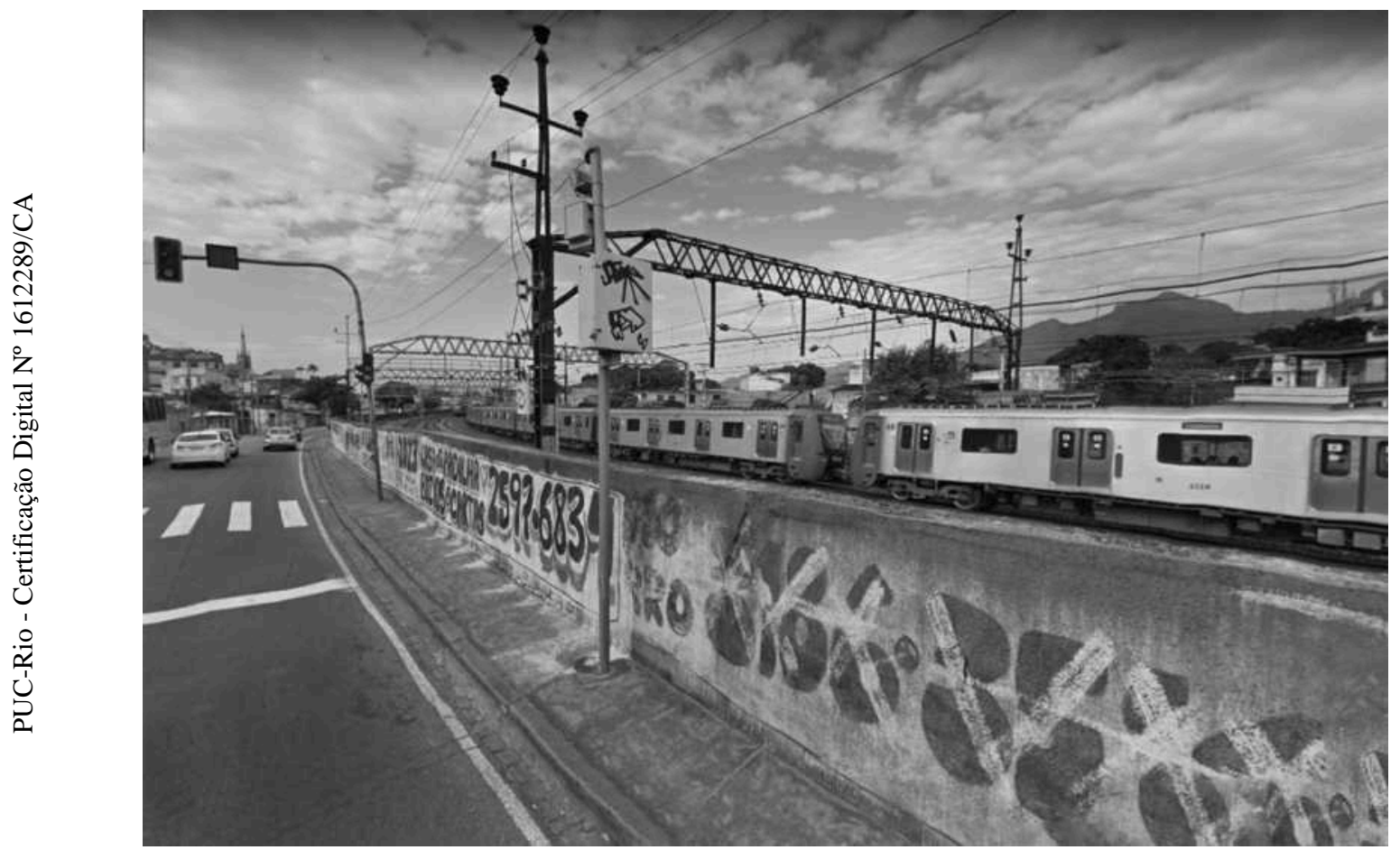

Figura 5. Muros em Quintino, Rio de Janeiro.

Estes limites são configurados por muros que acontecem em longos trechos do ramal ferroviário Santa Cruz e marcam dinâmicas socioeconômicas e culturais, a paisagem e o imaginário dos habitantes nestas margens urbanas. No que se refere às dinâmicas socioeconômicas, há, nestes trechos que acompanham os muros, uma predominância de fábricas, em sua maioria inativas, galpões de estacionamento, oficinas e residências. Claramente, há um processo de afastamento de investimentos e, consequentemente, de segurança nestes imóveis e espaços imediatos aos muros do ramal ferroviário Santa Cruz, fato que se 
apresenta de forma bem diferente nos pontos imediatos às estações de parada, onde podemos ver os centros econômicos e de serviços (Méier, Madureira, Bangu, etc) (ABREU, 2010, p. 50). No entanto, há no discurso hegemônico sobre o subúrbio carioca certo caráter bucólico no que se refere à cultura do transporte ferroviário. Embora os muros estejam altamente presentes na construção da paisagem, o trem é que assume o protagonismo no imaginário dos habitantes da cidade.

É possível identificar também que as relações estabelecidas entre estes muros e estas margens são mediadas pela presença de rodovias ao longo de grande parte de seu desenvolvimento territorial em direção ao subúrbio e a zona oeste carioca, fato que intensifica o seu sentido longitudinal de deslocamento. A ferrovia exerce um papel importante no que se refere a este processo de invisibilidade. Relaciono o seu modo de operação com o que Deleuze e Guattari colocam como regime de estriamento, onde "as linhas, os trajetos têm tendência a ficar subordinados aos pontos: vai-se de um ponto a outro" (DELEUZE; GUATTARI, 2017, p. 197). Este regime de funcionamento reflete a lógica da otimização e controle dos fluxos, em que prevalecem os pontos (as estações de parada) sobre as linhas (o percurso trilhado), fato que se reverbera para a construção destes muros.

Tal modo de operar nos ajuda a entender a invisibilidade percebida deste dispositivo muro e possibilita ainda uma aproximação com o que Deleuze e Guattari colocam como processo de formação de estratos:

Os estratos são fenômenos de espessamento no Corpo da terra [...] acumulações, coagulações, sedimentações, dobramentos [...] Apesar de suas distintas formas de organização e desenvolvimento, nem por isso um estrato qualquer deixa de ter uma unidade de composição (ibid., p. 230).

O muro parece operar como dispositivo de estratificação em conjunto com a ferrovia, na medida em que produz certo espessamento destas áreas, certa sedimentação de modos de deslocamento que tendem a formar unidades de composição bem definidas. É possível verificar nos discursos da historiografia hegemônica que as linhas ferroviárias geram uma divisão nos bairros onde passa (LINS, 2010, p. 151), reduzindo estes espaços estratificados mais finos, como o próprio muro, à nomenclatura "ferrovia". Tal fato torna-se sintomático, pois 
revela um resultado deste processo de estratificação que nos parece oportuno: sua invisibilidade.

Realizando um primeiro movimento para lançar luz sobre tal elemento, o muro enquanto mediador, enquanto dispositivo destas relações estabelecidas na experiência corporal com estas margens ferroviárias, é possível pensar que tal caráter de invisibilidade, paradoxalmente, abre uma oportunidade de construir outras formas de ver, de falar e de poder nestes elementos. Como operam estes estratos? Realizo uma aproximação com a reflexão que Ignasi Solà-Morales elabora em 1995 acerca de espaços abandonados nas grandes cidades, os quais nomeia de terrain vague:

São suas bordas carentes de uma incorporação eficaz, são ilhas interiores esvaziadas de atividades, são olvidos e restos que permanecem fora da dinâmica urbana. Convertendo-se em áreas simplesmente des-habitadas, in-seguras, improdutivas. Em definitiva, lugares estranhos ao sistema urbano, exteriores mentais no interior físico da cidade, que aparecem como contraimagem da mesma, tanto no sentido de sua crítica como no sentido de sua possível alternativa (SOLÀ-MORALES, 2002, p. 188).

Considerando que os espaços entre os muros e a ferrovia operam dentro de uma lógica que se aproxima desta categorização, o único momento em que o autor menciona as bordas destes espaços como parte dos fatores que contribuem para a definição deles como tais é quando diz "suas bordas carentes de uma incorporação eficaz [...]". Este fato me parece problemático, na medida em que as bordas são, a meu ver, fundamentais para a instauração destas condições espaciais na cidade contemporânea, pois são elas que permitem e impedem acessos, que guardam e liberam fluxos, sendo fundamentais no delineamento das dinâmicas que podem ocorrer nestes espaços. Ao considerar isto, é possível perguntar: em que medida tais espaços se configuram como espelhos de suas bordas e vice-versa?

Solà-Morales utiliza a noção de borda para falar deste encontro do terrain vague com a cidade, termo que insere maior flexibilidade e permeabilidade para estes elementos de delimitação de seus contornos. A meu ver, porém, os muros ao longo do ramal não operam como bordas, mas sim como limites que geram estratos bem definidos. Mesmo com esta diferenciação, os limites urbanos, assim como as bordas de terrain vague, carecem de incorporação, isto é, carecem de uma relação de flexibilidade e permeabilidade com os fluxos da cidade e da experiência corporal, eles tornam-se elementos de estriamento que, assim como os 
estratos que o cercam e o sedimentam como tal, podem produzir, de tempos em tempos e por diferentes motivos, a sensação de estranhamento no ambiente urbano. É o que os faz oscilar.

Diante deste fato, surgem uma questão: como pensar os muros para além de sua forma, embaçar seus limites e encontrar suas possibilidades de devir?

Penso que me apropriar da sensação de estranhamento que eles produzem ajuda a construir uma forma de atualização no dispositivo muro.

Sigmund Freud, em $O$ inquietante ${ }^{1}$, investiga as condições de aparecimento do estranhamento na percepção humana. Ao sair da dicotomia estranho/familiar, discute que, de maneira geral, este sentimento guarda sua raiz no retorno de um conteúdo reprimido no inconsciente, independentemente de sua origem afetiva. A estranheza é dada neste retorno em si e caracteriza-se por sua secreta familiaridade, desconstruindo, portanto, tal dicotomia. Ou seja, trata-se de algo que não é novo internamente - como pode muitas vezes parecer -, mas que foi afastado pela repressão. Algo que é, no limite, estranhamente familiar.

Já Anthony Vidler, em The Architectural Uncanny, transpõe este tema, assim como Solà-Morales em Terrain Vague, construindo importante contribuição para o pensamento sobre a arquitetura e a condição urbana contemporânea. Se por um lado o autor afirma que o estranhamento mostra, "sua estrutura profunda de um modo mais que analógico, demonstrando um deslizamento inquietante entre o que parece familiar e o que definitivamente é ao mesmo tempo estranho e familiar" (VIDLER, 2006, p. 620), por outro, coloca a dificuldade de se pensar um "estranho arquitetural", pois o estranhamento não se configura como uma propriedade do espaço em si, ou algo que é provocado por conformações espaciais específicas, mas é, em sua dimensão estética, uma representação de um estado mental de projeção que, precisamente, apaga as fronteiras entre o real e o irreal de forma a provocar uma ambiguidade perturbadora, um deslizamento entre acordar e sonhar (VIDLER, 2015, p. 621).

\footnotetext{
${ }^{1}$ Do original Das Unheimlich, é um texto produzido em 1919 por Sigmund Freud na discussão psicanalítica sobre as condições de aparecimento deste sentimento, o inquietante ou o estranho. Cf. FREUD, 2010, p. 329-376.

2 "Se construções ou espaços de fato são interpretadas por estas lentes, não é porque eles próprios possuem propriedades estranhas, mas sim porque eles agem, histórica e culturalmente, como representações do estranhamento. Se existe uma premissa única a ser derivada do estudo do estranho na cultura moderna, é que não existe tal coisa como uma arquitetura estranha, mas simplesmente uma arquitetura que, de tempos em tempos, por razões distintas, são investidas de qualidades estranhas" (VIDLER, 1992, p. 12).
} 
Tendo este fator em vista, entendo que, a partir desta discussão, Vidler coloca exatamente o fato de que o estranho não está somente no "Outro", isto é, não são somente os muros; mas ele está aqui, em nós mesmos, em um estado mental de projeção interna construído nesta relação. Tal fenômeno, a meu ver, possivelmente coloca que a abertura para uma operação estética do estranhamento, na medida em que engendra uma relação de alteridade, possivelmente produz processos de subjetivação específicos.

Solà-Morales desdobra sua reflexão em Terrain Vague neste sentido, colocando-se diante da possibilidade de pensar que estes espaços refletem ou podem produzir outras subjetividades na cidade dialogando, sobretudo, com reflexões engendradas por dois filósofos: (1) Odo Marquard, que pensa "a época da estranheza ante o mundo" discutindo a possibilidade de surgimento de um sujeito pós-histórico: “que convoca à presença do poder o escape de sua presença totalizadora, à seguridade uma vida de risco, à ordem urbana a indefinição do terrain vague"(MARQUARD apud SOLÀ-MORALES, 2002, p. 190), refletindo certa indistinção entre as ações estéticas e éticas no mundo; (2) Julia Kristeva, que, em Estrangeiros à nós mesmos, discute a condição de estrangeirismo na vida pública das sociedades, colocando, a partir do tema do Estranho de Freud, que "a estranheza dos homens e das mulheres contemporâneos é a estranheza ante eles mesmos, sua radical impossibilidade de se encontrar, de se localizar, de assumir sua interioridade como identidade" (KRISTEVA apud SOLÀ-MORALES, 2002, p. 190).

Traspondo esta discussão para o dispositivo muro, penso que ao considerar o estranhamento como uma categoria estética (VIDLER, 2006, p. 8) que produz subjetividades na cidade, ligadas ao risco, à impossibilidade de assumir algo fixo internamente; e que opera com a noção de alteridade, embaçando os limites entre o Eu e o Outro, entre o real e o irreal, podem ser construídos caminhos de desvio deste regime de estriamento que o congela em seu caráter de limite e produzir alisamentos, isto é, operar em um regime "onde os pontos estão subordinados ao trajeto [e onde] o trajeto que provoca a parada"(DELEUZE; GUATTARI, 2017, p. 197).

Assim, discutirei a deambulação enquanto errância que parece operar movida por um fluxo intenso entre o estranhamento, o corpo e a cidade, embaçando limites entre o real e o sonho, entre o "Eu" e os "Outros" urbanos. 


\subsection{Do caminhar entre o deambular: embaçando limites}

A utilização do caminhar como uma ação estética foi realizada pela primeira vez pelos dadaístas. A ação nos jardins da igreja de Saint-Julien-LePauvre, no ano de 1921 em Paris, ficou conhecida por marcar o deslocamento da crítica dadaísta para um vazio na cidade. A caminhada foi realizada pelo grupo Jean Crotti, Georges D’Esparbès, André Breton, Geroges Rigaud, Paul Éluard, Georges Ribemont-Dessaignes, Benjamin Péret, Théodore Fraenkel, Louis Aragon, Tristan Tzara e Philippe Soupault - e foi divulgada antecipadamente pela imprensa para os que quisessem conhecer o jardim da igreja. Careri diz:

[...] ready-made urbano realizado em Saint-Julien-le-Pauvre [...] a primeira operação simbólica que atribuiu valor estético ao vazio e não a um objeto. O dadá deixou de levar um objeto banal ao espaço da arte e passou a levar arte - na pessoa e nos corpos dos artistas dadá que compunham - a um lugar banal da cidade (CARERI, 2015, p. 75).

Esta ação teve como mote principal a crítica engendrada pelos dadaístas à arte que, de maneira breve, estaria ligada ao próprio seu próprio papel, enquanto instância crítica, colocando de forma irônica uma paixão pelo banal, pelo cotidiano, pelo ilógico como uma espécie de negação aos movimentos progressistas e otimistas então presentes nas vanguardas artísticas. Tendo este fator em vista, é possível identificar nesta ação seu caráter revolucionário no simples ato de conseguirem, conscientemente, realizá-la.

O registro principal da caminhada foi uma fotografia dos artistas no local em que eles, conscientes daquilo que estavam fazendo, isto é, especificamente nada, embora tenham lido textos do dicionário Larousse, tenham dado presentes a quem passava e tentado fazer com que as pessoas descessem a rua ao lado da Igreja. Este fato mostra certa postura dadá diante da não realização das outras caminhadas que tinham sido programadas, pois "ter realizado aquela ação naquele lugar tinha o valor de realizá-la na cidade inteira" (id., 2016, p. 77).

O lugar escolhido foi um jardim aparentemente abandonado desta igreja, em pleno Quartier Latin - no centro da cidade de Paris -, fato que, segundo Careri, mesmo não sabendo qual dos artistas que escolheu o local, parecia ser familiar a algum deles. Sendo assim, ao ser experienciado através desta 
caminhada, abriu a possibilidade de discussão acerca da busca de certo estranhamento em realidades urbanas familiares.

Mesmo ao levar em conta certa indagação de Careri, podemos perceber um primeiro "arrastamento". Ao entrar em contato com certa busca de estranhamento na cidade e, no entanto, não realizar mais nenhuma caminhada urbana, alguns artistas dadaístas como André Breton e Louis Aragon começam a entrar em uma zona de transição, em uma condição Entre, quando conectam-se intensamente com a obra de Freud, sobretudo no que se refere à descoberta do inconsciente. Há, neste momento, um desdobramento da crítica dadaísta e, assim, desta suposta busca por tornar estranha uma realidade familiar, para uma associação direta com o universo dos sonhos, da fantasia, da repressão, da pulsão de morte e muitos outros temas que a descoberta do inconsciente freudiano apresentava. A partir deste período em que haviam indefinições e incertezas sobre o que os artistas iriam produzir, Breton, Aragon e outros artistas iniciam o movimento surrealista ${ }^{3}$.

As deambulações surrealistas foram a primeira transposição direta da noção de inconsciente para caminhadas nas periferias urbanas (id., 2015, p. 78). Ao assumir o caminhar como um meio de expressão artística, construíram atravessamentos entre inconsciente, corpo e cidade, sobretudo através das noções de estranhamento e estrangeirismo fundamentais para esta discussão sobre o embaçamento de limites.

Sobre esta prática, Careri define:

A deambulação - termo que traz consigo a própria essência da desorientação e do abandono no inconsciente - desenvolve-se entre bosques, campos, sendeiros e pequenos aglomerados rurais. [...] A deambulação é um chegar caminhando a um estado de hipnose, a uma desorientadora perda de controle, é um medium através do qual se entra em contato com a parte inconsciente do território (ibid., p. 78-80, grifo do autor).

Quando Careri faz esta consideração, ele se refere sobretudo às deambulações realizadas pelos surrealistas. Este momento do início do século XX em que as cidades, sobretudo a cidade de Paris, sofriam grandes obras de modernização urbana após a Primeira Guerra Mundial, as deambulações surgiam

\footnotetext{
3 "Ao que parece, foi um puro acaso que recentemente trouxe à luz uma parte do mundo intelectual, a meu ver, a mais importante, e da qual se afetava não querer saber. Agradeça-se isso às descobertas de Freud. Com a fé nestas descobertas desenha-se afinal uma corrente de opinião, graças a qual o explorador humano poderá levar mais longe suas investigações, pois que autorizado a não ter só em conta as realidades sumárias. Talvez esteja a imaginação a ponto de retomar seus direitos" cf. BRETON, 1924.
} 
como uma reação de viés intensamente provocativo a estes movimentos produtivos da cidade.

Walter Benjamin em Surrealismo: o último instantâneo da inteligência europeia, complexifica os ideais do "movimento" levantando o seu caráter revolucionário para a época como uma reação de "pessimismo integral" ao choque da Primeira Guerra Mundial através das energias da embriaguez: "Em todos os seus livros e iniciativas, a proposta surrealista tende ao mesmo fim: mobilizar para a revolução as energias da embriaguez. Podemos dizer que é essa a sua tarefa mais autêntica" (BENJAMIN, 2014, p.33).

Há nestas observações dois pontos importantes que é possível inferir: (1) este "pessimismo integral" a que o autor se refere, ao que parece gerado através do estranhamento daquilo que é produtivo na modernidade urbana, no entanto, é exatamente com este estranhamento que os surrealistas produziam; (2) estas "energias da embriaguez" que se vinculam diretamente com certa vontade de fuga da cidade moderna e imersão no desconhecido do inconsciente estariam diretamente ligadas ao que Benjamin chama de "iluminação profana" e que Jacques traduz como:

[...] a própria experiência surrealista, a partir da embriaguez de sentidos, do embaralhamento entre realidade e imaginação, entre vigília e sonho, entre banal e super-real, que seria sempre experiência, e não teoria, e que se daria como os êxtases, não os religiosos ou alucinógenos, mas sim como uma iluminação profana, de inspiração materialista e antropológica (JACQUES, 2014, p. 129).

Ao colocar a experiência surrealista nestes termos, a meu ver, Jacques fornece um contorno intensamente corporal e, por isso, profanatório (id., 2010, p. 110) para a noção de inconsciente freudiana. Verificamos tal afirmação quando ele diz:

[...] a investigação mais apaixonada da embriaguez produzida pelo haxixe nos ensina menos sobre o pensamento (que é um narcótico eminente) que a iluminação profana do pensamento pode ensinar-nos sobre a embriaguez do haxixe. O homem que lê, que pensa, que espera, que se dedica à flanerie, pertence, do mesmo modo que o fumador de ópio, o sonhador e o ébrio, à galeria dos iluminados. E são iluminados

\footnotetext{
${ }^{4}$ (...) onde estão os pressupostos da revolução? Na transformação das opiniões ou na transformação das relações externas? Os surrealistas se aproximam cada vez mais de uma resposta comunista a esta pergunta. O que significa: pessimismo integral. Sem exceção. Desconfiança acerca do destino da literatura, desconfiança acerca do destino da liberdade, desconfiança acerca do destino da humanidade europeia, e principalmente, desconfiança, desconfiança e desconfiança com relação a qualquer forma de entendimento mútuo: entre as classes, entre os povos, entre os indivíduos. Cf. BENJAMIN, 2014, p. 34.
} 
mais profanos. Para não falar da mais terrível das drogas - nós mesmos - que tomamos quando estamos sós (BENJAMIN, 2014, p. 33).

Considerando isto, percebo que a noção de inconsciente começa a ganhar, para Benjamin, uma dimensão intensamente corporal e urbana importante no campo da arte, na medida em que as formas de acesso aos movimentos do inconsciente, que eram as substâncias alucinógenas, podem ser "trocadas", no caso dele, pela fâanerie (flanâncias, conforme Jacques), mas, no caso dos surrealistas, pelas deambulações.

Assim, os surrealistas tendiam a realizar estas práticas em lugares afastados dos centros urbanos, nos subúrbios, sobretudo de Paris, onde, para os artistas, seria possível entrar em contato com "a parte inconsciente do território", isto é, com as áreas desconhecidas, estranhas à cidade, como uma atitude de "pessimismo integral", como Benjamin diz, frente a esta realidade de modernização urbana do início do século XX. No entanto, existiam também as deambulações que aconteciam dentro das cidades, trazendo a possibilidade de reconhecer este inconsciente do território em áreas urbanas:

Os errantes que fizeram deambulações não estavam mais, como nas flanâncias, embriagados pela experiência e pelo choque da multidão nas ruas. Eles provocam a multidão, a devoram, entram nas passagens, se tornam passagens; como o trapeiro, recolhem os trapos, sobras, restos da cidade, e se embriagam com a própria fugacidade moderna, com a fugaz-cidade moderna. As passagens explicitam esse estado intermediário, a passagem entre antiguidade e modernidade, que tanto fascinava os surrealistas. Não se trata de forma alguma de nostalgia do antigo, pois a potência de estranhamento do cotidiano [...] reside exatamente em seu estado de eminente desaparecimento (JACQUES, 2014, p. 139).

É possível perceber que estas práticas pressupunham ou partiam da noção de inconsciente freudiano, mas que estavam intensamente implicadas pela noção de "estranhamento do cotidiano" ou de certo "estrangeirismo", como uma espécie de condição na qual seria possível ampliar, construir ou "devorar" outras formas de apreensão e conhecimento do espaço urbano. Estranhar o produtivo e, nesta condição, produzir.

Jacques relaciona esta incorporação do estranhamento como uma espécie de categoria estética em que este tipo de errância opera a uma espécie de postura "etnográfica surrealista" urbana e diz:

Os errantes realizam uma aproximação entre uma postura etnográfica, ou melhor, antropológica [...] e a cidade; poderíamos pensar em [...] uma postura 
"etnográfica surrealista" urbana. Trata-se efetivamente de uma etnografia voraz, faminta, insaciável. Nota-se que a alteridade, o estrangeiro, o estranho, o Outro, não está mais somente longe, em sociedades ditas primitivas ou exóticas: pode estar bem próximo, no meio das multidões anônimas, andando pelas ruas das grandes cidades modernas (ibid., p. 124).

Ao mesmo tempo, reconhece que os primeiros surrealistas realizavam uma espécie de "etnologia às avessas" (ibid., p. 124), no sentido de que, ao invés de tornar familiar aquilo que se apresenta como estranho, buscavam tornar o cotidiano familiar no estranho, no Outro, através de suas deambulações. No entanto, sem certa pretensão de encaixá-los como uma prática antropológica ou etnográfica, entrando assim em meandros científicos sobre as definições disciplinares, Jacques aponta para a possibilidade de reconhecer certa "sensibilidade etnográfica voraz" (ibid., p. 125) nestas práticas como forma de colocar sua potência enquanto ferramenta de crítica urbana.

Assim, é possível pensar que, se por um lado, perceber que o Estranho está bem próximo, por outro, esta proximidade gera uma postura "etnográfica surreal" produtiva, na medida em que constrói outras relações com a cidade através dos sonhos, dos movimentos do inconsciente sempre vinculadas ou afetadas com os "Outros" na cidade.

As narrativas destas experiências de alteridade urbana, que são as deambulações, eram montadas principalmente através do método da escrita automática.

Podemos perceber estas montagens em dois livros marcantes do grupo: (1) Nadja (1928) de André Breton, em que o narrador-personagem funde-se com a cidade de Paris ao escrever sobre sua busca onírica e apaixonada por Nadja, uma personagem criada em sonho; e (2) Camponês de Paris (1926), de Louis Aragon, em que o narrador-personagem nos fala da entrada ou do encontro onírico de um camponês com a cidade de Paris em processo de modernização, trazendo em sua escrita o entrincamento intenso entre sonho e realidade.

Já no Brasil do início do século XX, especificamente final dos anos 1920 e início dos anos 1930, o movimento de antropofagia cultural, sobretudo através de Oswald de Andrade, apresenta alinhamentos importantes a se considerar nesta discussão com o pensamento surrealista. Jacques diz:

[...] no Manifesto Antropófago[...] Oswald de Andrade deve [a sua leitura de Freud] uma das passagens mais importantes de seu texto, uma síntese surrealista, 
poderíamos dizer: "Antropofagia. A transformação do Totem em Tabu" [...] Em outra passagem, o surrealismo é claramente citado: já tínhamos a língua surrealista. A edade de ouro. Catiti Catiti, Imara Notiá, Notiá Imara, Ipejú. (JACQUES, 2014, p. 108)

Realizando uma citação às avessas do texto Totem e Tabu (1912) de Freud, como um questionamento provocador sobre as influências estrangeiras na arte brasileira, Oswald de Andrade reivindicava através deste Manifesto a construção do que seria este processo de antropofagia cultural.

Este diálogo entre os surrealistas e os artistas do movimento antropofagia cultural (JACQUES, 2014, p. 108) apresenta alguns caminhos que a noção de inconsciente e, por desdobramento, a de estranhamento tomaram no campo da arte brasileira. Este momento de troca, de mistura entre práticas artísticas configura um segundo "arrastamento" nesta investigação: a relevância das deambulações realizadas pelo artista Flávio de Carvalho, ligado a Oswald de Andrade e a este movimento.

Flávio de Carvalho conheceu os artistas surrealistas parisienses em seus anos de estudo fora do país (ibid., p. 110) e realizou uma série de deambulações em cidades brasileiras, sendo a mais relevante para esta discussão a Experiência n2, em 1931, publicada no mesmo ano como livro, Experiência n2: Uma possível teoria e uma experiência, que se tratava de uma deambulação no sentido contrário a uma procissão de Corpus Christi na cidade de São Paulo.

$\mathrm{O}$ artista entra em uma procissão católica e começa a caminhar no sentido contrário à procissão, vestindo um chapéu, ao contrário de todos os "fiéis" que acompanhavam o sentido de fluxo do evento. Logo o artista, que tinha um interesse provocativo, gera um incômodo na multidão, que cresce na forma de protestos. Ao construir esta narrativa, o artista faz descrições de viés etnográfico sobre a situação criada. Ele diz:

Os protestos aumentavam. A multidão me comprimia: o ambiente estava pesado e hostil. Segui meu caminho como pude, apertado e cutucado, já agressivamente. Com dificuldade conseguia passar; os homens não se arredavam um dedo, e era obrigado a empurrá-los docilmente. As mulheres da assistência permaneciam passivas, tanto quanto me foi possível observar. Meu estado já era de agitação. Eu percebia claramente que a minha presença indesejável não poderia ser aturada por muito tempo, e apesar dos protestos irritantes que ecoavam ao meu ouvido como uma ameaça crescente, conservei meu chapéu na cabeça e procurei manter uma aparência de calma (CARVALHO, 2001, p. 20). 
É possível perceber na narrativa de Flávio de Carvalho a sua abertura para os movimentos particulares da multidão e sobretudo para o afeto psicológico que estes geravam no seu corpo. Tal escrita era atravessada pela prática da escrita automática e livre associação de ideias (JACQUES, 2014, p. 120) utilizada pelos surrealistas como uma espécie de fluxo produtivo do inconsciente

Esta experiência, que se desdobrou na prisão temporária do artista e posteriormente em uma notícia de jornal, produziu uma série de reflexões do artista acerca do tema das multidões, fazendo-o pensar na necessidade de criação de uma nova disciplina, uma "psicoetnografia", isto é, uma psicologia das multidões para analisar estes tipos de experiência estética.

A partir desta experiência deambulatória de Flávio de Carvalho, profundamente vinculada ao encontro afetivo com as multidões urbanas (JACQUES, 2014, p. 115), penso que é possível considerar um dispositivo multidão e perceber a potência de atualização que este deambular carrega a partir da geração de uma condição Entre, que provoca os limites que a própria multidão imputa à sua experiência corporal. Movimentar-se no sentido contrário à multidão configura-se como uma montagem de zonas de desestabilização, de atrito, de imprevisibilidades dentro do meio, arrastando suas margens e adquirindo velocidades singulares. No entanto, toda esta condição é gerada, sobretudo, pelo estranhamento.

Esta categoria estética que move conteúdos do inconsciente e promove um deslizamento perceptivo-mental entre o real e o irreal, como Vidler coloca, me parece configurar-se como "motor" da deambulação realizada por Flávio de Carvalho. Ela move todas as produções que foram desdobradas pela multidão, como é possível perceber em sua narrativa, sendo provocada tanto nas pessoas quanto no próprio artista. Uma experiência de alteridade que, ao operar nas linhas de fuga do dispositivo multidão, expõe as relações entre suas linhas de estratificação (a fé dos fieis, os modos de caminhar na procissão, as vestimentas) e de atualização (todas as produções que foram geradas a partir da errância do artista).

Neste sentido, a deambulação incorpora o estranhamento como uma categoria estética capaz de produzir outras narrativas urbanas e, assim, gerar a partir de suas linhas de fuga outras linhas de força (outras formas de "Poder") nos 
dispositivos urbanos. No caso de Flávio de Carvalho, no dispositivo multidão, neste caso aqui estudado, no dispositivo muro do ramal ferroviário Santa Cruz.

Este muro configura um limite e estratos bem definidos e, mesmo sendo invisibilizado enquanto dispositivo, é familiar à vida cotidiana nos subúrbios e zona oeste carioca. Está vinculado a um movimento de expansão no território, de desenvolvimento longitudinal como uma extensão da própria ferrovia.

Neste sentido, a prática da deambulação parece ser uma forma de produzir outros movimentos nestes locais, através de sua operação pelo estranhamento. Sua capacidade de gerar deslizamentos de percepção, de embaçamento entre o real e o irreal, de ir contra os movimentos hegemônicos, através de uma experiência materialista e antropológica, como coloca Benjamin na noção de "iluminação profana", parece ser a forma de engendrar atualizações nestes limites rígidos.

A busca de um tensionamento da familiaridade de tais muros através da deambulação configura-se como uma operação na condição Entre: é uma via de apreensão e compreensão que opera a partir da alteridade, gerada pelo estranhamento, num espaço estabelecido Entre termos, isto é, num espaço de movimento entre os muros e a rua. Tal condição aponta, como veremos, para estes lugares desviando-se de sensações de certeza, de ordem - dentro/fora, horizontal/vertical etc. -, tão intrínsecas a estes limites, e incorporam outras como imprevisibilidade, abandono e fluidez. Neste caso, a narrativa que será apresentada configura-se como uma escrita afetiva e poética à situação de limite deste muro e guarda potência para geração de outras possibilidades de experimentação urbana, assim como faz o estrangeiro para Didi-Huberman:

O estrangeiro, assim como a estranheza, tem como efeito lançar uma dúvida sobre toda realidade familiar. Trata-se, a partir deste questionamento, de recompor a imaginação de outras relações possíveis na própria imanência dessa realidade. É ainda isto, distanciar: fazer aparecer toda coisa como estranha, como estrangeira, depois tirar disto um campo de possibilidades inauditas (DIDI-HUBERMAN, 2017b, p. 67, grifo meu). 


\subsection{Muros do Estranho: atualizações no Engenho de Dentro}

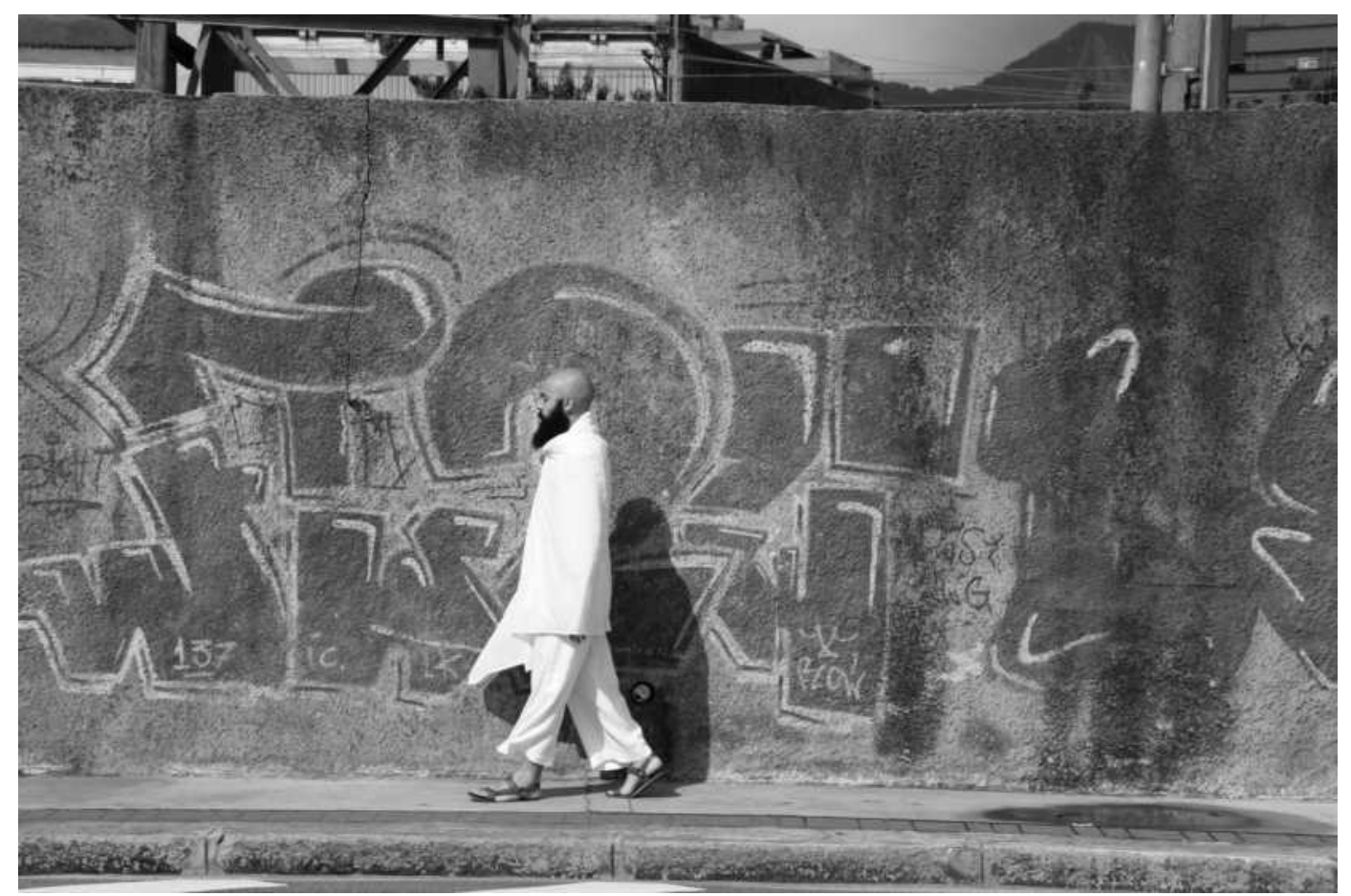

Figura 6. Deambular no meio. Engenho de Dentro, Rio de Janeiro.

Frio. Lençol. Alívio. Enrolá-lo em mim: um aviso do vento. Como se eu precisasse colocar mais uma casca no corpo, só que moldada por ele. Não entendo bem, mas como o vento sempre me traz bons caminhos, segui. Identidade em casa. Rua.

Passo a mão na barba, na careca, de branco e um lençol enrolado no corpo. Por aqui as pessoas me conhecem. Como será que irão reagir? Mas o vento me lembra que está comigo, assim não preciso me preocupar desta forma com os outros, somente estar aberto, assim como o lençol que se desenrola do meu corpo e quer voar. Ele parece me lembrar que a reação dos outros aconteceria também em mim. Paz. Seguir.

Mulher segurando a mão de uma criança, olha para frente, me vê e, séria, continua olhando para o final da rua. O seu olhar é de quem não poderia olhar de frente para mim. A criança, ao contrário, aponta o dedo e se mexe em minha direção. Recebê-la. Mulher puxa o braço da criança e continua olhando para o final da rua. Produzir contato. Con-ta-to. Com-tato. Parei e virei meu corpo em direção à criança que já tinha passado da minha posição.

Chôro. Puxão no braço e “vamos, Rodrigo!”. 
Virar, esperar um pouco para ver se a mulher irá parar com a criança.

Costas e nada.

Percebi logo que a minha presença por aqui soa inquietante, mas continuo aberto ao contato. Logo a primeira buzina, seguida de um grito. O carro é vermelho, mas passou rápido e não consegui discernir o que foi dito, embora o grito possa ser ouvido por quem estava na esquina da rua. Vermelho e grito. Calor do susto misturado com o frio que o vento logo me lembra.

Enrolar o lençol. Atravessar a rua.

Passos dados e outras buzinas dadas. Dessa vez não se permitiram expor a voz na cidade, colocar-se através da voz. Preferiram a máquina.

Ainda impactado com o grito anterior. O barulho da cidade impacta no ritmo com que as pessoas andam. "A rua que eu acreditava que fosse capaz de imprimir à vida giros surpreendentes, a rua com suas inquietações e seus olhares, era o meu verdadeiro elemento: nela eu recebia, como em nenhum outro lugar, o vento da eventualidade (tradução minha)" ${ }^{, 5}$. Rua. Modernizar. Moderno a custo de que? Vejo poucas pessoas, mas que não sentem o chão. Seguem o fluxo mental e o corpo responde. Automatismo do corpo.

Acelerar o movimento levemente torto, como se eu tivesse, ainda, que dar conta do grito que me foi dirigido a poucos minutos. O lençol, no entanto, ajuda e acolhe meu desconforto.

Som dos trens. Ferrovia e o corpo no eixo da calçada estreita. Pensei em colocarme à disposição dos muros que caminham ao longo desta calçada e lhes perguntar quais eram suas revoltas. Não pode ser possível que estar fadado à disciplina do alheio seja algo fácil.

Passo a passo vou descobrindo como, eu senti.

A proximidade com a via de carros é muito grande e a possibilidade de andar normalmente fica mais difícil. Velocidade alta, vento forte, o lençol me lembra disso a todo tempo, como se ele estivesse tentando me dizer algo. Percebo que era algo sobre equilíbrio.

\footnotetext{
5 "La rue, que je croyais capable de livrer à ma vie ses suprenant détour, la rue avec ses inquietudes et ses regards, étais mon veritable élément: j’y prenais comme nulle part ailleurs le vent de l'éventuel" Cf. BRETON, 1969, p. 11.
} 
Pergunta: Como diante desta rapidez e fluidez pode um corpo se equilibrar? Meio metro de calçada, meu corpo e o fluxo intenso de carros às dez horas da manhã de uma quinta-feira. Quem pensou nisso?

Parar e Respirar.

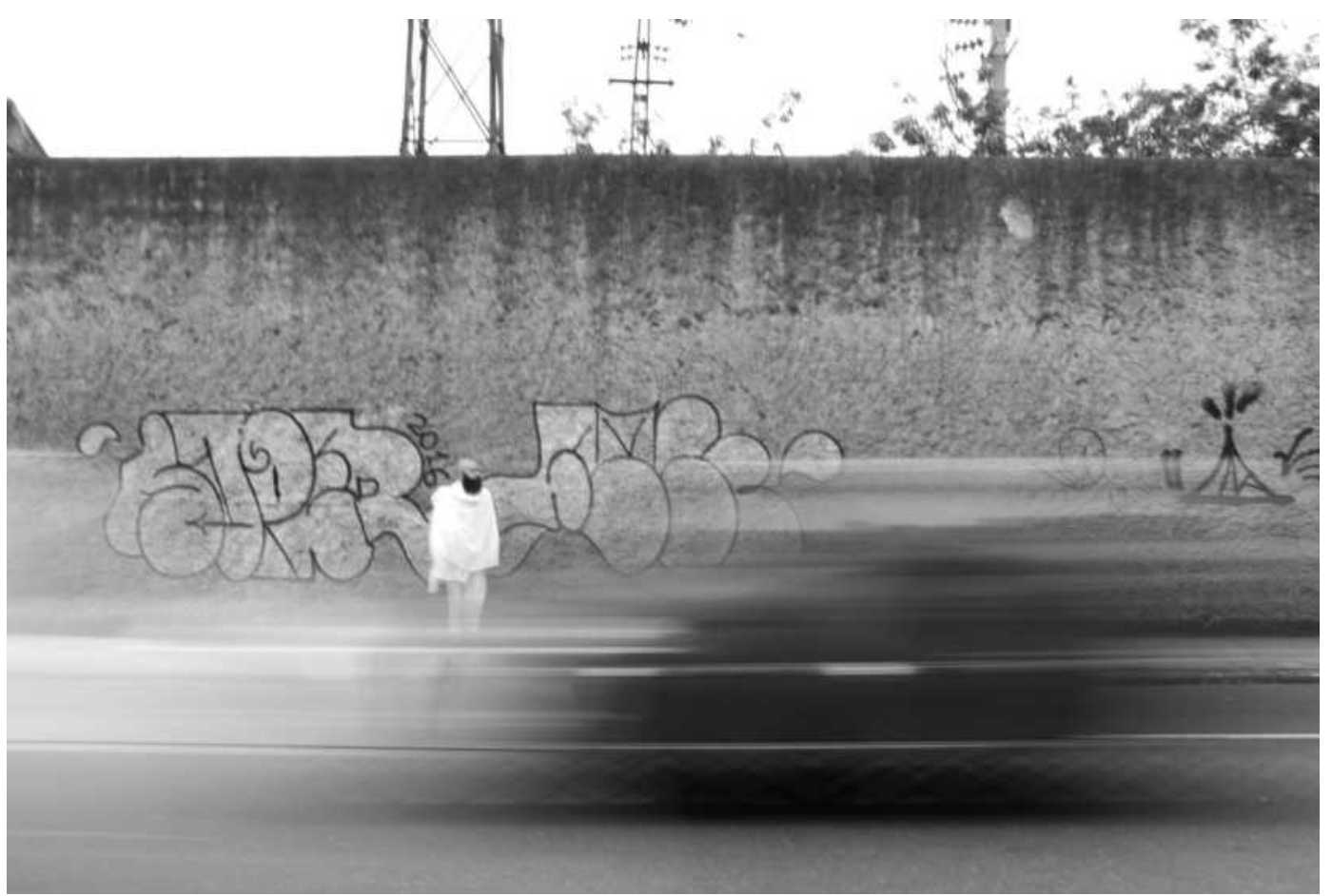

Figura 7. Deambulação e fluxos. Engenho de Dentro, Rio de Janeiro.

Respirar este ar que vinha do movimento de carros foi a forma de dar conta do meu corpo neste lugar. Vir do movimento. "[...] pensar e ser são uma só e mesma coisa. Ou antes, o movimento não é imagem do pensamento sem ser também matéria do ser”6. É nele que a vida se dá, que a vida acontece. É nele que nos encontramos com nós mesmos. Alívio de respirar para engolir todo este movimento cego pelas narinas.

Exatamente assim recebo uma buzina mais longa e um braço para fora quase nos meus olhos. Carro sem cor. Muro de carros, carros murados fluindo à frente. "Soleiras [...] ainda podem ser encontradas nos subúrbios e na natureza; na cidade elas são esquecidas. Algo desta sensibilidade, delineia uma série de observações sobre a cidade contemporânea $[\ldots]^{7}$. Aferir a percepção para o que escapa na cidade. Quantas pessoas estão passando por aqui agora? Quantas histórias parecem estar muradas neste movimento incessante de motores, capuz e pneus?

\footnotetext{
${ }^{6}$ Cf. DELEUZE, 1992, p. 54.

${ }^{7}$ Cf. VIDLER, 1992, p. 184.
} 
Adquirir um olho para as transições, para aquilo que se faz presente depois que já se foi. Soleiras. A buzina e o braço de fora já foram há muito tempo.

O braço me mostrou certo relaxamento, certa tranquilidade, mas, novamente, há uma ausência de voz, através da presença de uma máquina. "Nas máquinas desejantes tudo funciona ao mesmo tempo, mas nos hiatos, nas panes e nas falhas, nas intermitências e nos curtos-circuitos, nas distâncias e nos despedaçamentos, numa soma que nunca reúne suas partes num todo" ${ }^{\Perp}$. Desmontar qualquer possibilidade de discernimento entre o que é expressão e o que é conteúdo dos agenciamentos ou dispositivos com os quais me relaciono a todo tempo. Desterritorializar o visível e o enunciável, misturá-los, atuar sobre linhas de fuga. Não sei se a buzina quis me caçoar ou quis dizer que estava me vendo. Seu som me veio, certamente, como uma grande interrogação.

Respirar. Dar passadas.

O movimento dos carros que passam logo ao meu lado convoca uma caminhada mais lenta. Capturar esse muro de fluxo. Diminuo o tempo.

Uma pessoa vem ao longe. Chinelo, bermuda preta, camisa verde, boné. Seu ritmo já me diz que não quer contato. Meu corpo enrijece por dentro, mas o lençol permite que eu continue a receber o vento: olhe nos olhos dele. Assim o fiz.

Passo a passo me aproximo do rapaz, que logo viu que eu o observava nos olhos. Ele para, olha para o outro lado da rua, reconhece a possibilidade de atravessar entre os carros e corre levemente para chegar do outro lado. Um segundo de contato visual e fuga ao encontro.

Recebi tal ação. Senti meu estômago enrijecido e continuei dando passos para a frente, lentamente.

Ver através. Através do fluxo de carros é possível ver um espaço amplo: galpões, rampas, bicicletas, corridas. Sensação de que atravessar a rua seria equivalente a atravessar um mar. O fluxo de carros embaça a percepção e é possível conectarme com um movimento maior de pessoas e atividades do outro lado da rua. Chegar na estação. O Estádio. Ferro. Branco. Seguir.

Outra mulher segurando a mão de uma criança.

Afetar. Afeto. Produzir o afeto, continuando a caminhar lentamente.

Ela está apontando para mim e me mostrando para a criança.

\footnotetext{
${ }^{8}$ Cf. DELEUZE apud ZOURABICHVILI, 2004, p. 65.
} 
“Olha Mateus, olha lá!”. Ela repete “Olha, filho! Olha!”.

Pela primeira vez me senti visto, mas não durou muito. A mulher retira da bolsa um celular e começa a me filmar. Uma mão filma, a outra segura a criança. "No espetáculo, uma parte do mundo se representa diante do mundo e lhe é superior. O espetáculo nada mais é que a linguagem comum dessa separação. O que liga os espectadores é apenas uma ligação irreversível com o próprio centro que os mantêm isolados. O espetáculo reúne o separado, mas o reúne como separado".9 $\mathrm{O}$ culto às imagens. Passeio. Turismo. Evento. Tive esta sensação, pois pude me ver na tela daquele celular, mas não nos olhos daquela criança.

Corpo enrijecido. Olhar para a criança.

A criança não riu. E mesmo com o entusiasmo da mãe, continuava sem reação. Me senti visto por três segundos, achei que estivesse andando, mas estava parado há um tempo no mesmo lugar.

Respirar. Continuar.

“Em cinco minutos, partirá trem para Deodoro da plataforma 4, linha D. Atenção com o espaço entre o trem e a plataforma". Uma gravação. Gravar a ação que se repete ao longo do dia se direcionando a milhares de pessoas, entrava pelos meus ouvidos. Dispositivos acionados para informar e disciplinar os fluxos. Sua expressão e seu conteúdo estão definidas, territorializadas. Mas que territorialização é esta? Havia três homens: um segura a escada, outro estica o fio e segura uma enxada e o terceiro em cima da escada emassa uma marquise. Todos os três olharam na minha direção, viraram o rosto novamente e riram entre si. Emassar a marquise é o objetivo. Objetivação da vida. Objetificação da vida. Me senti objeto de graça. “A territorialização é o ato do ritmo tornado expressivo, ou componentes de meios tornados qualitativos"10. Que territorialização é esta? “Territorializar” é, para Deleuze e para Guattari, sedimentar, estratificar, estriar funções, ideias, percepções, fluxos. Ali é possível saber o que é expressão e o que é o conteúdo das coisas, exatamente como acolhi esta situação: o riso que prosseguiu o olhar para mim, era um estranhamento diante da minha presença que se manifestou na forma de graça, de chacota para eles. No entanto, nada feito para mim, em minha direção. Tudo feito entre e para eles. Tudo para eles. E, assim, me dei conta de que havia um muro entre nós. Que territorialização é esta?

\footnotetext{
${ }^{9}$ Cf. DEBORD, 2016, p. 23.

${ }^{10}$ Cf. DELEUZE apud ZOURABICHVILI, 2004, p. 45.
} 
Frio. Me dei conta novamente quando o lençol se desenrolou do meu corpo. Pude perceber a rigidez do meu corpo quando o vento bateu e eu já conseguia ficar de pé sem balançar tanto com a força dos carros passando ainda próxima ao meu corpo. Enrolei novamente o lençol. Vento.

Fechar os olhos, apoiar uma mão nos muros e a outra no ar.

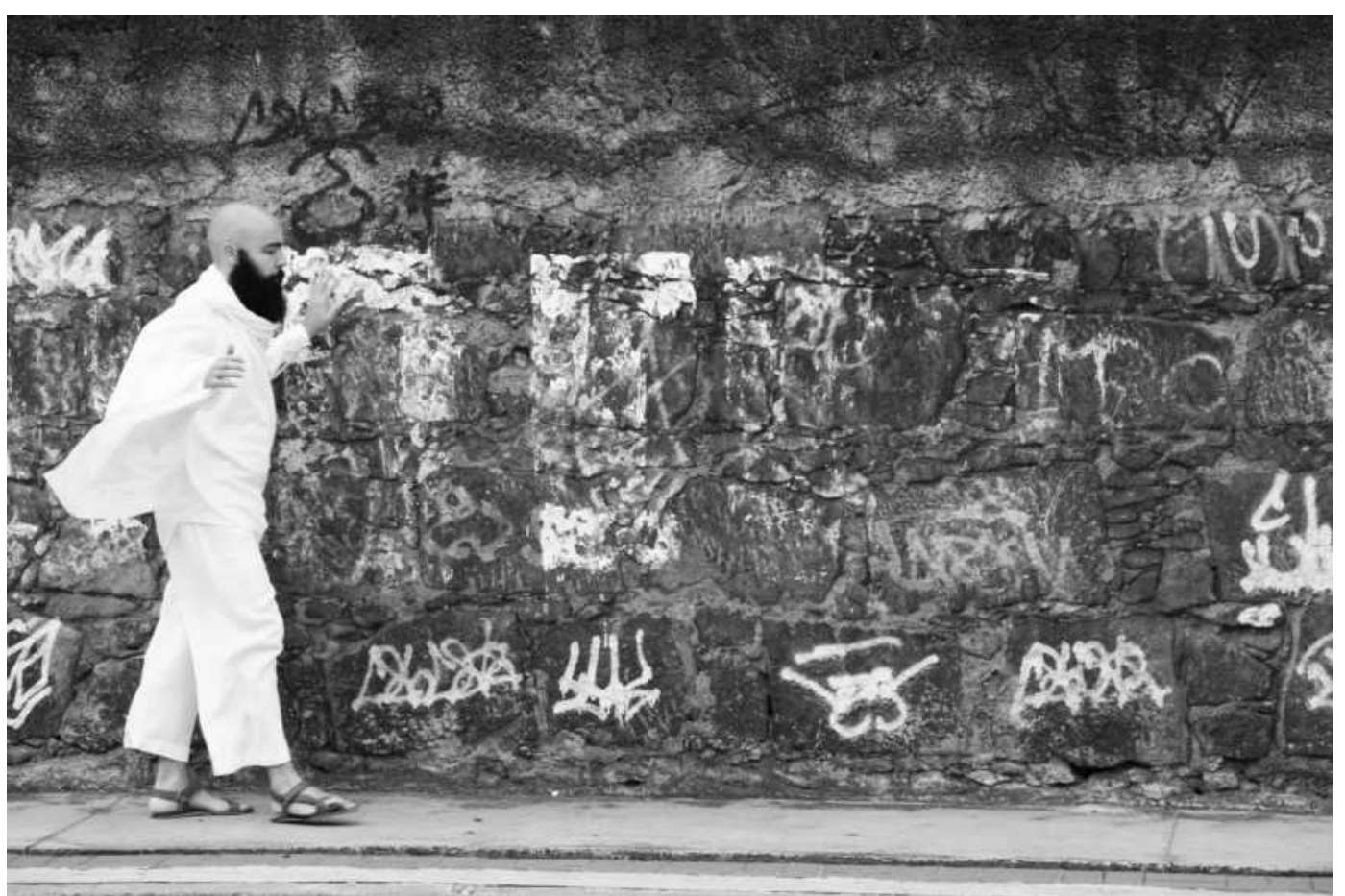

Figura 8. Deambulação na terceira margem. Engenho de Dentro, Rio de Janeiro.

Experimentar o fluxo de carros e os muros com a ponta dos dedos aconteceu no meu corpo como um teste de equilíbrio. Me sentindo enrijecido com todos os muros que me deparei ao longo do caminho, me senti como uma ponte: firme, porém aberto aos fluxos que vêm de uma margem e de outra. Ou melhor, como o leito de um rio, uma terceira margem, arrastando as duas margens pelas quais atravessa. "Sofri o grave frio dos medos [...] Sei que agora é tarde e temo abreviar com a vida nos rasos do mundo. Mas, então, ao menos, que, no artigo da morte, peguem em mim e me depositem numa canoinha de nada, dessa água que não para de longas beiras: e, eu, rio abaixo, rio a fora, rio adentro - o rio"11.

Perceber o fio tênue que as conecta, mas que precisava de um canal visível. Rio. Estar aberto aos vínculos energéticos do espaço e as possibilidades estéticas que eles possibilitam. Rio. Assim me coloquei. Rio.

Como eu poderia descrever essa sensação?

\footnotetext{
${ }^{11}$ Cf. ROSA, 1994, p. 413.
} 
Rio eu, como Guimarães Rosa, no meio de um rio. Eu e o rio. Eu-rio.

Olhos fechados e o corpo aberto arrastando os muros deslizantes no corpo como um ato de misericórdia por sua condição de impenetrabilidade. O lençol fazia com que o meu corpo realizasse esta ação, liberando a rigidez, a secura e certa familiaridade existente sobre estas energias, através de sua possibilidade de ir com o vento e tornar-se outra coisa a todo segundo. Arrastar estes dois "muros" com as mãos. Um duplo murado. "O duplo foi originalmente uma garantia contra o desaparecimento do $\mathrm{Eu}[\ldots] \mathrm{Na}$ cultura do antigo Egito, ele impulsionou a arte de construir uma imagem do morto em material duradouro. Mas essas concepções surgiram no terreno do ilimitado amor a si próprio, do narcisismo primário [...] e com a superação desta fase, o duplo tem o seu sinal invertido: de garantia de sobrevivência passa a inquietante mensageiro da morte"12. Fluxo impenetrável de carros de um lado, fluxo impenetrável de pedras do outro. Seria aquele duplo uma mensagem da morte de seu outro? Seriam estes, dois de um mesmo?

Continuo como parte desse duplo. A terceira margem que o arrasta. Abro os olhos. Ninguém me vê.

Pessoas passavam do outro lado da rua, mas pareciam flutuar nas calçadas seguindo o fluxo de seus pensamentos e desejos. Ao que parece este "duplo" está em constante movimento, pois os muros parecem estar em muitas coisas, se desdobrando, invadindo corpos.

Assumindo o deslocamento deste duplo para as coisas e pessoas, recusei a visão novamente e segui a mensagem:

Virar de costas, encostar a testa nele.

\footnotetext{
${ }^{12}$ Cf. FREUD, 2010, p. 352.
} 


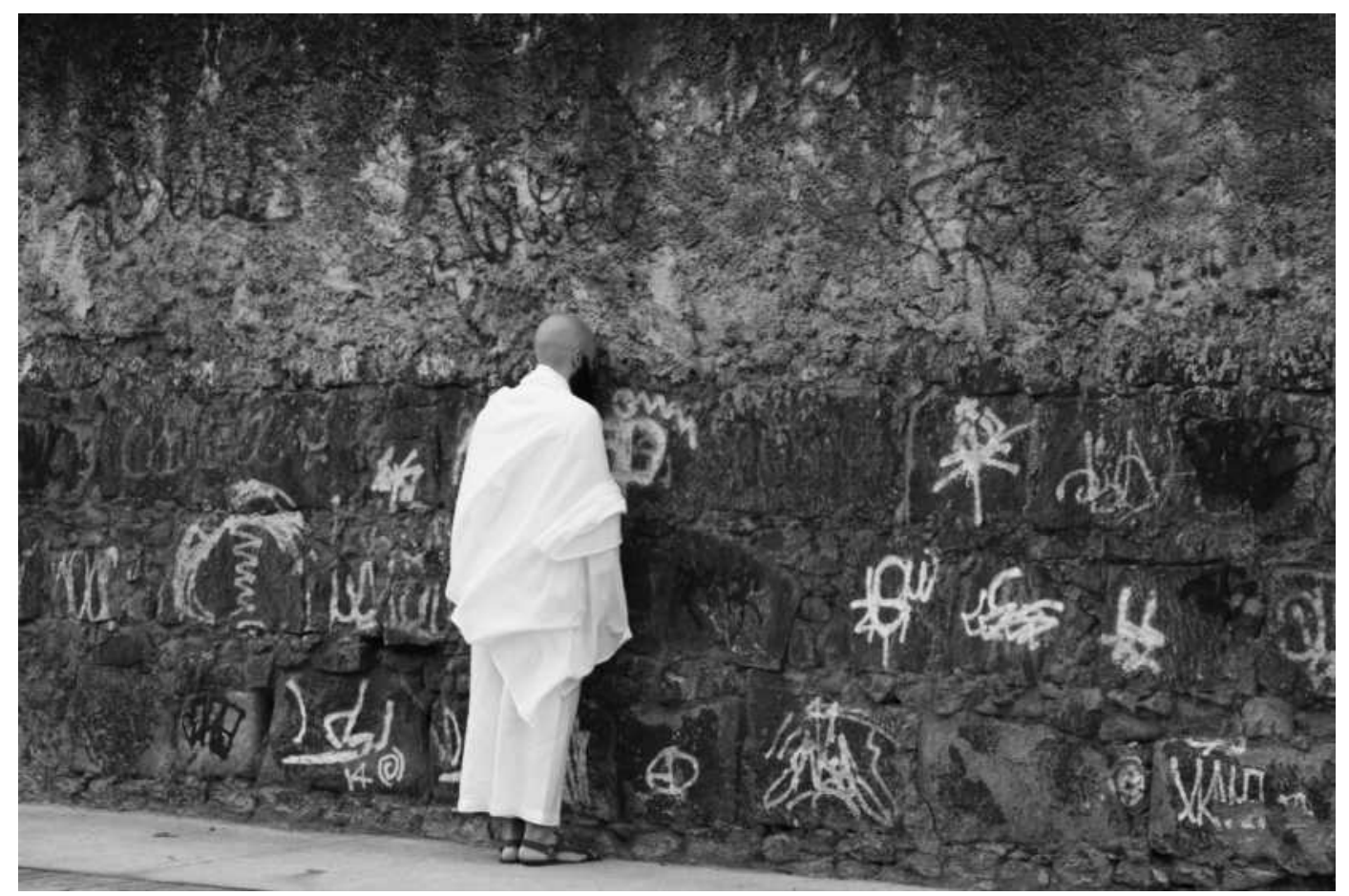

Figura 9. Cascas do deambular. Engenho de Dentro, Rio de Janeiro.

Passar um tempo enxergando por outras vias.

Desta forma eu consegui sentir que o enrijecimento do meu corpo era fruto dos fluxos, forças e energias que me atravessaram. Sentia a testa arranhar no concreto, mas meu corpo entendia aquele registro. Pude sentir as muitas cascas que foram produzidas ao longo deste percurso de afeto murado, de muros deslizantes. "A casca não é menos verdadeira que o tronco. É inclusive pela casca que a árvore, se me atrevo a dizer, se exprime. Em todo caso, apresenta-se a nós. Aparece de aparição, e não apenas de aparência. A casca é irregular, descontínua, acidentada. Aqui ela se agarra à árvore, ali se desfaz e cai em nossas mãos. Ela é a impureza que advém das coisas em si. Enuncia a impureza - a contingência, a variedade, a exuberância, a relatividade - de toda coisa. Mantém-se em algum lugar na interface de aparência fugas e de uma inscrição sobrevivente. Ou então designa, precisamente, a aparência inscrita, a fugacidade sobrevivente de nossas próprias decisões de vida, de nossas experiências sofridas ou promovidas"13 Estou próximo de Didi-Huberman: as cascas dizem tanto quanto os troncos. Marcas. Tempo. Intempéries. Unhas de animais.

Mas que em determinado momento saem e podem ser quebradas, desmontadas, deslocadas ou virar terra novamente. Meu corpo, casca grossa, precisava de atrito

\footnotetext{
${ }^{13}$ Cf. DIDI-HUBERMAN, 2017, p. 71.
} 
para rachar e poder ser descascado ou virar terra novamente. Continuar a pisar no caminho. Arrastar-me pelo muro.

Outras buzinas vieram em minha direção, não sei bem se começavam muito antes de passar por mim, mas na minha frente elas alcançavam seu auge. Umas três eu pude contar. A calçada tinha espaço para passar só mais uma pessoa, mas teria que se arrastar no meu corpo para seguir. $O$ vento novamente me trouxe orientações: Abaixe, coloque o lençol sobre você e espere.

Assim o fiz.

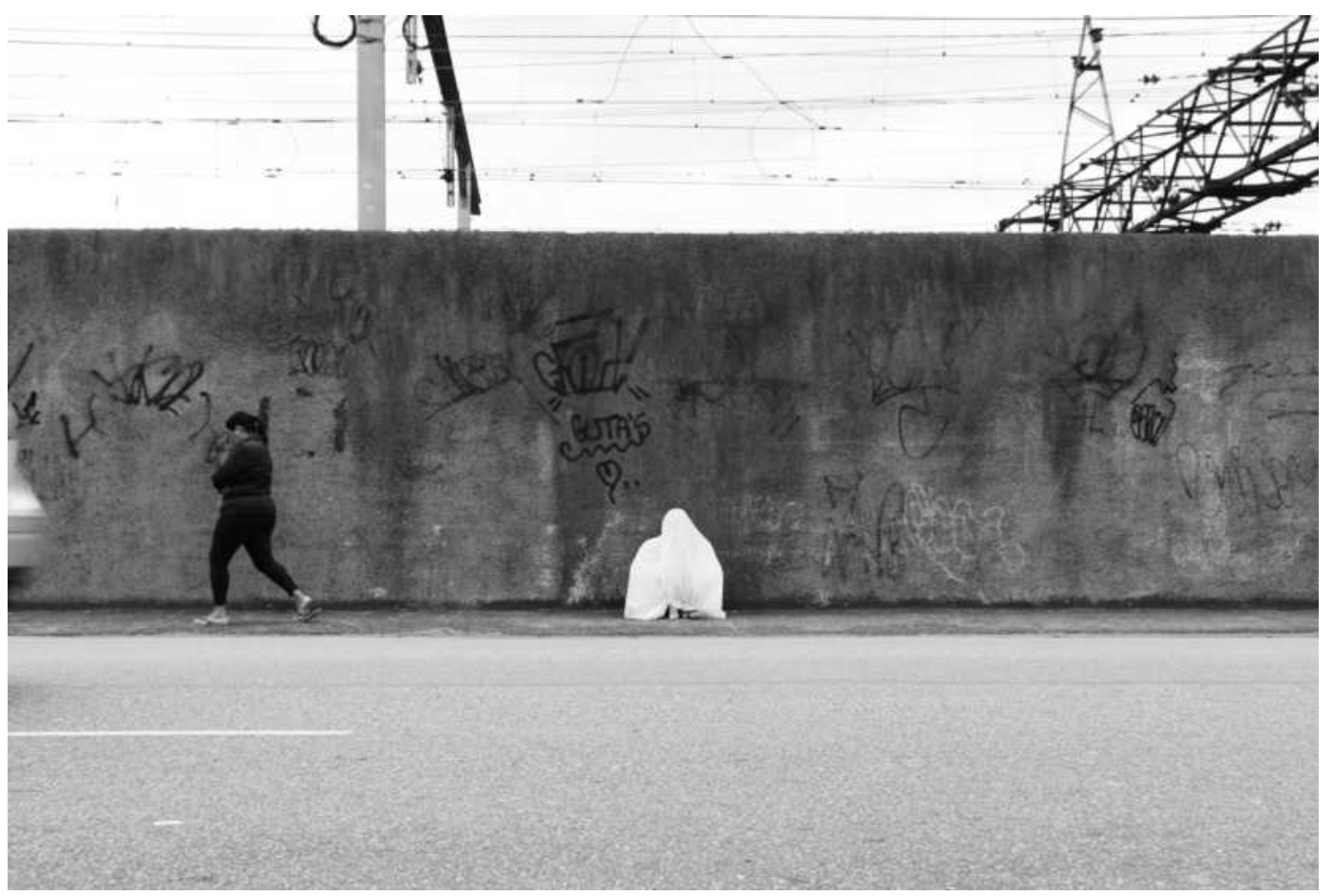

Figura 10. Deambulação e o ventre. Engenho de Dentro, Rio de Janeiro.

Logo entendi: abaixar neste espaço é impedir a passagem. Não seria mais possível qualquer pessoa passar sem me pular, desviar de mim ou pedir licença. $O$ contato era inevitável. Abaixar e me cobrir com o lençol. Medo. Alívio. Inquietação. Conforto.

Uma espécie de ventre materno.

"Para algumas pessoas, a ideia de ser enterrada viva por engano é a mais inquietante de todas. Mas a psicanálise nos ensina que essa apavorante fantasia é apenas a transformação de uma outra, que originalmente nada tinha de pavorosa, e era mesmo sustentada por uma certa lascívia: a fantasia de viver no ventre 
materno" $" 14$. O medo da clausura, de espaços que provocam de alguma forma esta sensação de retorno ao primeiro espaço ocupado por nós.

Neste momento, cobrir o corpo com este pedaço de tecido branco fino me levou para lá. Meu corpo duro, cheio de afetos encascados, sendo arrastado para baixo de uma superfície acolhedora, maleável, flutuante, que ao mesmo tempo, embaçava a minha visão sobre a cidade, e me alimentava dos nutrientes necessários para absorver a impenetrabilidade, a rigidez e a secura dos muros que eu vinha atravessando, só com o seu ventar, sua adaptabilidade aos fluxos e forças deste lugar. Um útero urbano.

Nestas condições, me senti um estrangeiro em casa. Protegido e alimentado por um lençol e inteiramente submetido, moldado e invadido pelos movimentos mudos da cidade. Fiquei alguns minutos nesta posição, neste útero, sentindo o que aconteceria.

Pessoas cruzaram por mim, indo para a rua e continuando no sentido desejado.

Vultos e titubeios. Titubear. Ti-tu-be-ar. Estar com dúvidas sobre que caminhos seguir.

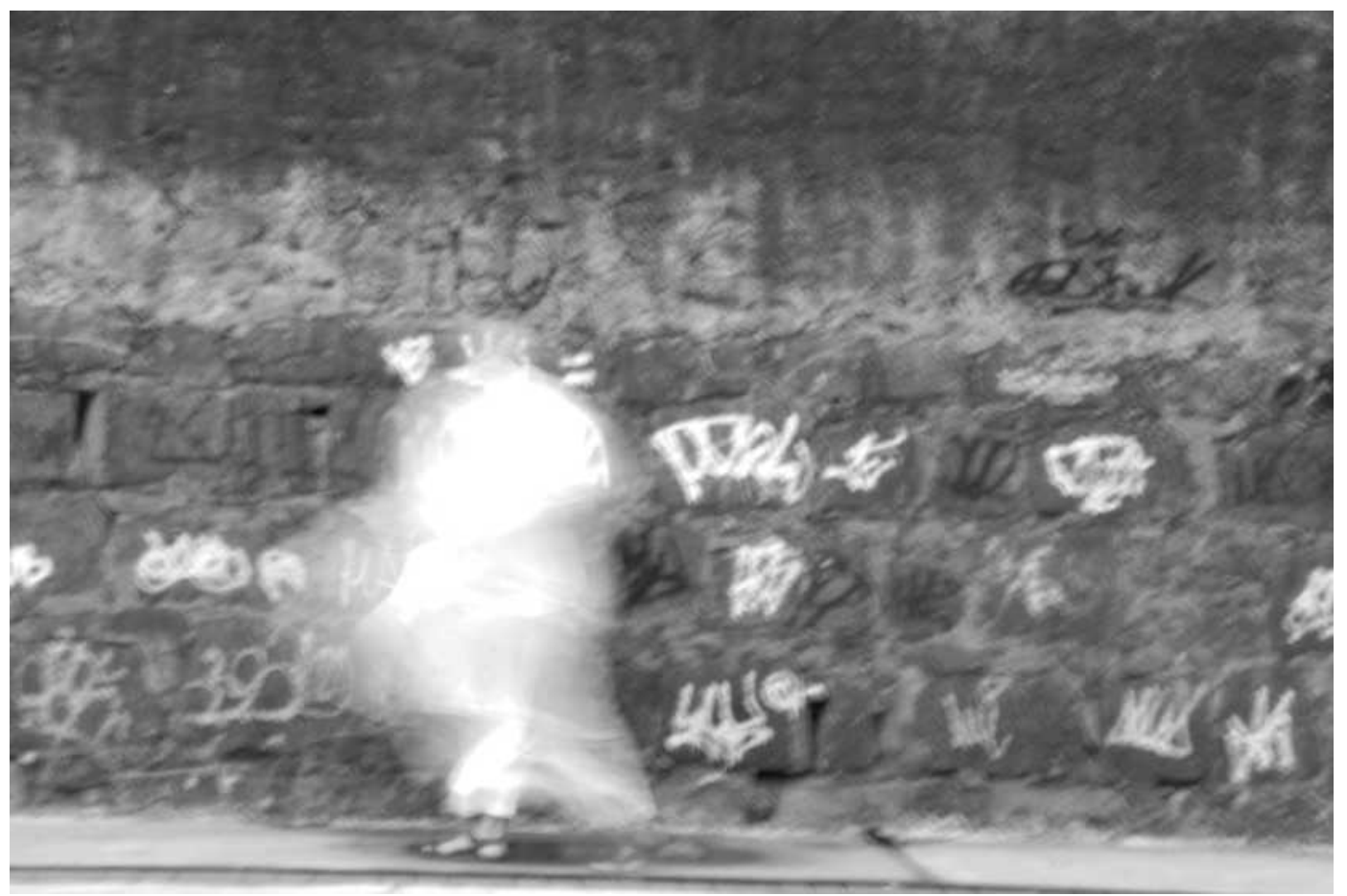

Figura 11. Movimentos do deambular. Engenho de Dentro, Rio de Janeiro.

Era isto: lançar dúvidas. Dúvidas que brotariam nas relações entre o meu deambular e os muitos muros que aparecem e escapam no segundo seguinte.

\footnotetext{
${ }^{14}$ Cf. FREUD, 2010, p. 364.
} 
Relações, re(l)ações familiares que foram vividas a partir do estranhamento e acolhidas assim. Pensei que Muros do Estranho podem estar em muitos outros lugares...dentro e fora e dentro e fora deste corpo...

O lençol saiu da minha cabeça e já voaria com o vento.

Segurei-o no ar e pensei que, sem se despedir, talvez ele quisesse construir mais um muro urbano e escapar no segundo seguinte.

Preferi estar em dúvida sobre suas vontades e enrolei-o novamente no pescoço. Quantos muros podemos embaçar juntos?

Lenvantar e continuar e continuar e continuar. 


\section{Restos}

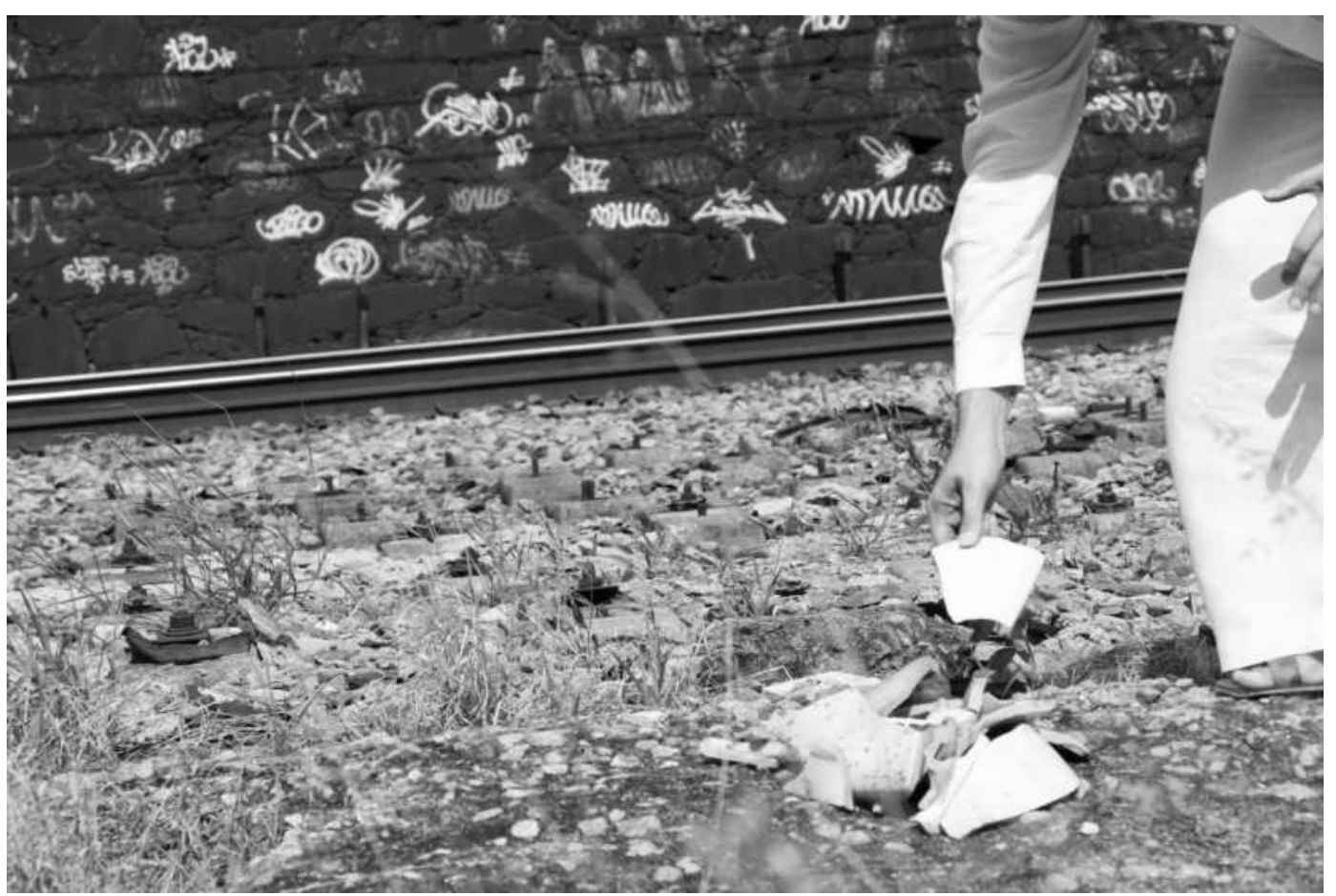

Figura 12. Deriva entre muros e trilhos do ramal ferroviário Santa Cruz. Engenho Novo, Rio de Janeiro.

Ao contrário das falenas que se consomem com a chama, os pirilampos do inferno são pobres "moscas de fogo" - fireflies, como se chamam em língua inglesa os nossos vagalumes - que sofrem em seu próprio corpo uma eterna e mesquinha queimadura. Plínio, o Antigo, inquietou-se, outrora, com uma espécie de mosca chamada pyrallis ou pyrotocon, que só podia voar no fogo: "Enquanto ela está no fogo, ela vive; quando seu voo a afasta dele um pouco mais, ela morre". Assim, a vida dos vaga-lumes parecerá estranha e inquietante, como se fosse feita da matéria sobrevivente - luminescente, mas pálida e fraca, muitas vezes esverdeada - dos fantasmas. Fogos enfraquecidos ou almas errantes. Não nos espantemos de que o voo incerto dos vagalumes, à noite, faça suspeitar de algo como uma reunião de espectros em miniatura, seres bizarros com mais, ou menos, boas intenções ( DIDI-HUBERMAN, 2014, p. 13).

\subsection{Atento a sobrevivências}

Ao realizar viagens de trem no ramal ferroviário Santa Cruz, é possível identificar a condição de invisibilidade dos espaços entre os muros e os trilhos do trem. O movimento da ferrovia opera no regime de estriamento deleuze/guattariano, isto é, onde os pontos prevalecem sobre as linhas, sendo que tais linhas, segundo os autores, têm uma natureza dimensional ou métrica: "o que cobre o espaço estriado [...] é o céu como medida, e as qualidades visuais 
mensuráveis que derivam dele" (DELEUZE; GUATTARI, 2017, p. 198). Este regime, ao que parece, constrói uma relação de distanciamento em relação aos espaços urbanos que são atravessados ao realizar tais viagens, na medida em que tais viagens são movidas pelos pontos de parada e não pelo percurso entre os pontos. Este fato, no entanto, não exclui a possibilidade de reconhecer certos "alisamentos" nestes locais, como por exemplo: os vendedores ambulantes no trem, os músicos de rua que ali trabalham, os jogos de carta e as rodas de samba no interior dos vagões, os tombos com as frenagens inesperadas, etc.

No entanto, a relação que se cria com o espaço externo imediato a este percurso é sobretudo uma espécie de contemplação visual - por vezes comprometida pelo aumento da velocidade dos trens - que acontece especialmente quando passam por locais mais altos ou com uma visão ampliada do território. Este fenômeno gerado por este regime de estriamento, a meu ver, fortalece a invisibilidade que determinados espaços entre estes muros e a ferrovia apresentam, e expõem uma maneira de entender o modo com que as linhas de estratificação do dispositivo muro vêm se construindo. Sobre este processo de "formação de estratos", Deleuze e Guattari dizem:

Um estrato apresenta, evidentemente, formas e substâncias muito diversas, códigos e meios variados. Portanto, possuí a um só tempo Tipos de organização formal e Modos de desenvolvimento substancial diferentes que o subdividem em paraestratos e epistratos [...] (DELEUZE; GUATTARI, 2017, p. 230).

Os espaços entre os muros e a ferrovia incorporam este processo de estratificação, gerando certa unidade de composição para estes locais que apresentam tipos de organização formal e modos de desenvolvimento substancial específicos de áreas abandonadas da cidade, de áreas invisibilizadas por fatores diversos. No sentido de entender estes estratos por outro viés, relaciono-os à noção de terrain vague discutida por Solà-Morales:

São lugares aparentemente esquecidos, onde parece predominar a memória do passado sobre a do presente. São lugares obsoletos nos que somente valores residuais parecem se manter apesar de sua completa desafeição da atividade da cidade. São, em definitiva, lugares externos, estranhos, que ficam fora dos circuitos, das estruturas produtivas (SOLÀ-MORALES, 2002, p. 187). 


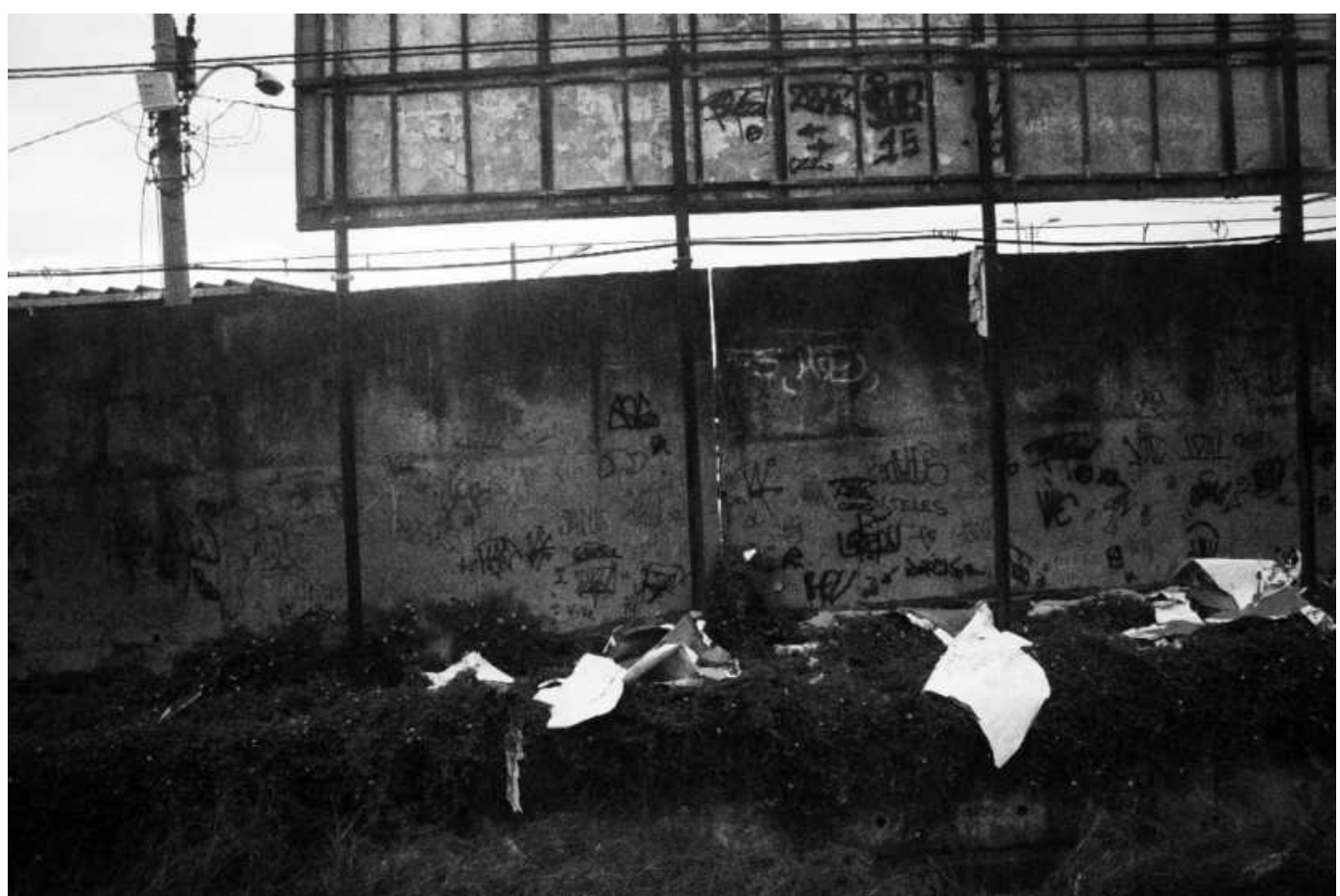

Figura 13. Restos em Deodoro, Rio de Janeiro.

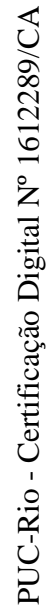

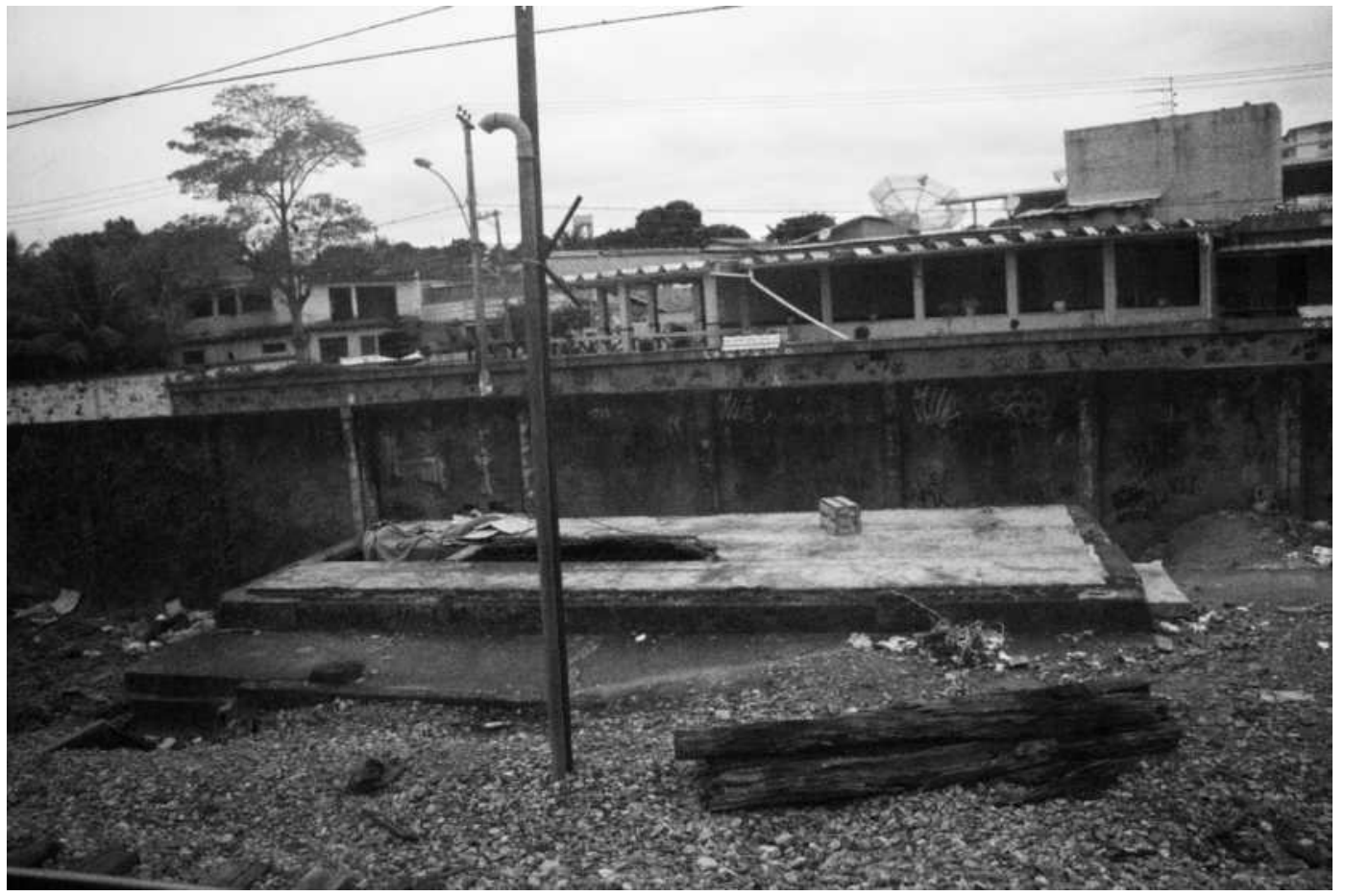

Figura 14. Restos em Madureira, Rio de Janeiro. 


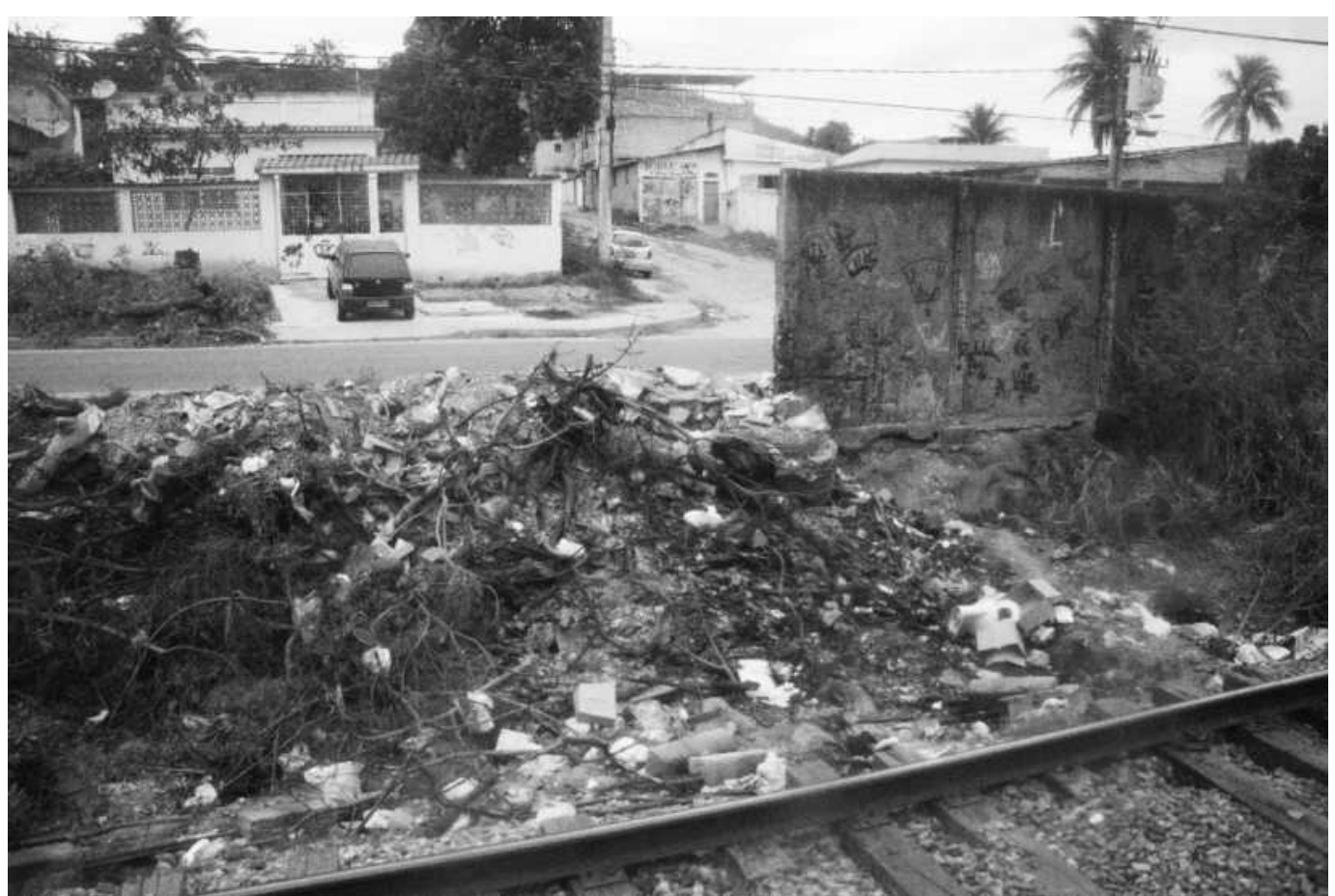

Figura 15. Restos em Magalhães Bastos, Rio de Janeiro.

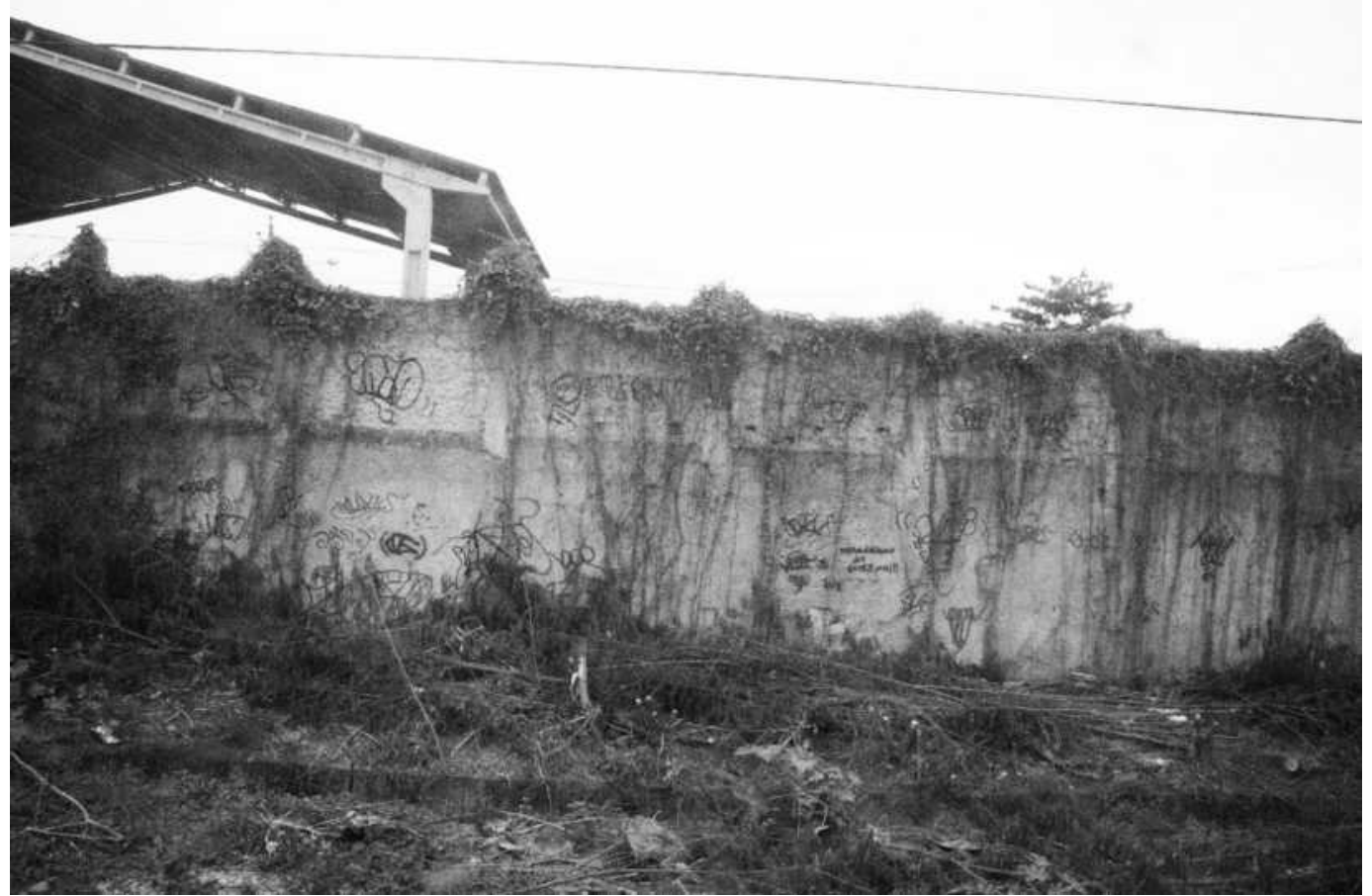

Figura 16. Restos em Bangu, Rio de Janeiro.

É possível reconhecer que há diversas situações ao longo do ramal ferroviário Santa Cruz em que de fato acontecem estes espaços entre muros e ferrovia que operam majoritariamente segundo a lógica do abandono, dos restos de um tempo passado. Tais espaços configuram-se como parte constitutiva do dispositivo muro, na medida em que afetam e são afetados diretamente pelo 
discurso do controle e proteção da ferrovia que os fortalecem como tais. No entanto, simultaneamente, Solà-Morales coloca um outro viés de abordagem para estes locais:

A relação entre a ausência de uso, de atividade, e o sentido de liberdade, de expectativa, é fundamental para entender a potência evocativa que os terrain vague das cidades tem na percepção da mesma nos últimos anos. Vazio, portanto, como ausência, mas também como promessa, como encontro, como espaço do possível, expectativa (ibid., p. 187).

Ao entendê-los desta maneira, o autor permite certa subversão deste discurso hegemônico sobre o muro. Possibilita tirar partido da invisibilidade destes espaços - que de certa maneira estão "mortos" para cidade, pois são locais em que "não se vê", "não se fala" e "não se passa" - como forma de encontrar sua potência crítica, e, assim, desdobrar novas experiências, atualizações no dispositivo muro.

É possível, a partir desta abordagem, levantar duas questões importantes: como falar sobre a condição de "resto", de "restante", de "restar" nestes locais? Seria possível construir uma experiência nestes locais que protagonize exatamente este "restar", não somente de coisas, mas também de pessoas que, ao serem encontrados, sentidos, vividos, podem sobreviver?

Penso assim que a noção de sobrevivência pode ajudar a construir desdobramentos para estas questões. Jacques reflete sobre esta noção dialogando com Aby Warburg, Benjamin e Didi-Huberman, e diz:

\begin{abstract}
Nachleben, aqui traduzido por "sobrevivência" - em alguns textos, encontra-se "vida póstuma" ou sobrevida -, seria um processo de transmissão, de transformação, de recepção e também de como a memória, sobretudo a involuntária (proustiana) ou inconsciente (freudiana) opera nestes processos. Trata-se de uma forma de presença ou de "herança" [...] de um tempo que ainda sobrevive, mesmo que em breves lampejos mneumônicos, em outro tempo. Um tipo de anacronismo pautado na questão da memória [...] (JACQUES, 2018, p. 211).
\end{abstract}

Para falar sobre esta noção, Jacques se remete ao Atlas Mnemosyne (1929) de Aby Warburg: tratava-se de um conjunto de painéis que tinham milhares de fotografias que eram montadas, desmontadas e remontadas ao longo de sua pesquisa. Este conjunto de imagens heterogêneas - de obras de arte, de detalhes de obras, imagens cosmográficas, cartografias, mapas, etc. - levantavam exatamente articulações complexas entre os temas da memória e da história, pois 
operam a partir dos processos de montagem-desmontagem-remontagem, isto é, tem como método a noção de montagem.

A questão principal que se coloca a partir deste Atlas de Warburg é, segundo Jacques, "aquilo que ele chamou de Nachleben der Antike, um tipo de sobrevivência - um tipo de "vida" que ressurge em outra época, algo que permanece vivo na memória e assombra épocas posteriores" (JACQUES, 2018, p. 210). Esta noção ajuda a construir, ou melhor a abrir um entendimento destes restos como sobrevivências, como pedaços da vida cotidiana que foram descartados, mas que podem fazer emergir memórias involuntárias, como nos sonhos, operando de forma fragmentária, não-linear e anacrônica.

Walter Benjamin traz uma contribuição fundamental para o pensamento sobre montagem, ligado exatamente a esta questão das sobrevivências: primeiramente em seu livro Rua de Mão Única ${ }^{15}$, em que monta mais de setenta fragmentos de narrativas baseadas em uma flanância sua ao longo de uma rua de mão única em Berlim. Em seguida, na compilação de milhares de fragmentos de textos, citações e imagens próprias, frutos de suas flanâncias pelas galerias de Paris no início do século XX e publicada no livro Passagens ${ }^{16}$. Em ambas as obras, o autor opera a partir do método de montagem, mas neste último ele diz:

Método deste trabalho: montagem literária. Não tenho nada a dizer. Somente a mostrar. Não surrupiarei coisas valiosas, nem me apropriarei de formulações espirituosas. Porém, os farrapos, os resíduos: não quero inventariá-los, e sim fazerlhes justiça da única maneira possível: utilizando-os. (BENJAMIN, 2006, p. 502)

Os "farrapos" da cidade são, para Benjamin e Warburg, possibilidades de engendramento de atualizações nas formas de construir a história, escovando-a à contrapelo" (id., 2014, p. 244-245), na medida em que constroem suas narrativas partindo da perspectiva dos restos, dos "vencidos" e não dos "vencedores" da história. Tal posicionamento gerado por esta prática de montagem gera uma discussão sobre as sobrevivências que se desdobra por vários campos. Como diz Didi-Huberman:

Teologicamente falando - já que Benjamin também falou esta língua - significa que não há redenção futura sem a exegese dos textos mais antigos [...] Psicologicamente falando [...] não há desejo sem o trabalho da memória, não há futuro sem reconfiguração do passado [...] Politicamente falando [...] não há força

\footnotetext{
${ }^{15}$ Do original Einbahnstrasse publicado no ano de 1928.

${ }^{16}$ Do original Das Passagen Werk publicado no ano de 1982.
} 
revolucionária sem remontagem dos lugares genealógicos, sem rupturas e reurdiduras dos laços de filiação [...] (DIDI-HUBERMAN, 2016).

Transpondo esta discussão para o dispositivo muro, penso que este entendimento da potência dos restos, através da noção de sobrevivências pode configurar novas formas de "Saber" e "Poder" acerca destes muros, pois darão protagonismo ao que é invisibilizado por eles, expondo, mesmo que em lampejos frágeis de luz, as condições políticas de sua construção. A quem interessaria, por exemplo, blindar com os muros todo o trecho atravessado pelo ramal ferroviário Santa Cruz?

Como Didi-Huberman diz, em Sobrevivência dos vagalumes (2014), acerca da potência que os lampejos de luz frágil e tremeluzente dos vagalumes da história têm de remontar a hegemonia na construção historiográfica das cidades contemporâneas. Mesmo aparentemente extintos nas grandes cidades, os vagalumes ainda podem ser vistos em locais onde a cidade encontra uma relação mais fluida com a natureza, funcionando como matéria sobrevivente ao fogo que lampeja em seus próprios corpos. Neste trabalho, a atenção aos restos, enquanto matéria sobrevivente ao tempo, poderá remontar afetos a partir das memórias produzidas por meio da errância, no entanto, operando na busca de produzir "alisamentos", isto é, onde a linha (o percurso) prevalece sobre os pontos (as sobrevivências). As linhas no regime de alisamento deleuze/guattariano são de natureza direcional, sendo "ocupada por acontecimentos [...] muito mais do que por coisas formadas e percebidas. É um espaço de afetos, mais do que de propriedades" (DELEUZE; GUATTARI, 2017, p. 198). Desta forma, a atenção às sobrevivências será subordinada a estes acontecimentos e afetos produzidos nos percursos errantes nestes locais.

Assim, discutirei a deriva enquanto errância que parece ter um modo de operação que parte de uma postura ativa sobre estes espaços entre muros e a ferrovia, aberto ao acaso e atento às sobrevivências, sem inventariá-las, como possivelmente fariam as deambulações, mas utilizando-as, como sugere Benjamin, de forma a produzir outros sentidos a partir deste encontro.

\subsection{Do deambular entre o derivar: ativando restos}

A utilização das deambulações pelos artistas surrealistas e pelo artista brasileiro Flávio de Carvalho no movimento antropofagia cultural no Brasil 
guarda potência para a discussão acerca de críticas urbanas geradas a partir de uma busca de estranhamento nas cidades. Para além desta potência produtiva que verifico no embaçamento de limites, de barreiras, é possível pensar na conexão que estas práticas possuem com os restos, chamados por alguns de resíduos da cidade. $\mathrm{O}$ artista brasileiro diz:

A sensibilidade do homem é, precisamente, os ossos do mundo organizados em coleção [...] O homem que vive no seu mundo, mas raramente se dá o trabalho de examinar o mundo em que vive. Um exame dos objetos do mundo e das coisas encontradas no correr da vida, não somente desperta nova sensibilidade no indivíduo, e que antes se achava adormecida, mas também estabelece uma ligação anímica maior entre o indivíduo e o objeto examinado [...] Sem dúvida, por ironia natural, as recordações da história se congregam nos resíduos abandonados pelo homem e não destruídos [...] (CARVALHO, 2014, p. 52-53).

Neste sentido, é possível inferir que o artista entende os resíduos, que neste trabalho são chamados de restos, como sobrevivências, pois além deste reconhecimento da necessidade de exame e coleta dos "ossos do mundo", ele insiste em falar destes resíduos como uma "memória do não acabado" (JACQUES, 2014, p. 122). E é exatamente a partir desta "coleção de sobrevivências" que podem ser estabelecidas outras relações entre corpo e objetos, sendo, no limite, certa reconstrução da relação com a cidade em si.

Ao identificar esta postura de Flávio de Carvalho diante das sobrevivências é possível localizar uma primeira zona Entre, um primeiro "arrastamento": reconhecendo a necessidade de estabelecer uma "ligação anímica maior entre o indivíduo e o objeto examinado", é possível reconhecer no artista certa tendência a inventariar tais restos. Sendo assim, Flávio de Carvalho deixou o caminho aberto ao desenvolvimento de práticas urbanas que construíssem uma relação de utilização com tais sobrevivências, a partir de uma postura mais ativa, na construção com a cidade. A deriva surge, assim, décadas depois, como uma prática situacionista que arrasta esta questão atrelada às deambulações, desdobrando-a para as possibilidades que se abriam no contexto das grandes cidades, sobretudo de Paris dos anos 1960.

A deriva foi criada e utilizada como uma prática urbana a partir de final dos anos 1950 pelo grupo dos situacionistas. Ao retomar o caminhar como uma ação estética e instigados pelas provocações realizadas através das deambulações surrealistas, o grupo assume esta errância como uma possibilidade de 
atravessamento, a meu ver, entre a cidade preexistente e os múltiplos afetos que seus espaços podem gerar. Neste sentido, Guy Debord define:

A deriva se apresenta como uma técnica de passagem rápida por ambiências variadas. O conceito de deriva está indissoluvelmente ligado ao reconhecimento de natureza psicogeográfica, e a afirmação de um comportamento lúdicoconstrutivo, o que o torna absolutamente oposto às tradicionais noções de viagem e passeio (DEBORD, 2003, p. 87)

Para iniciar esta discussão, podemos ver que há uma ligação intrínseca da deriva com o estudo da psicogeografia, que também é definida pelo autor como o "estudo dos efeitos exatos do meio geográfico, conscientemente planejados ou não, que agem diretamente sobre o comportamento afetivo dos indivíduos" (DEBORD, 2003, p. 65).

Tendo em vista estas duas definições, podemos dizer que a deriva, enquanto prática da psicogeografia, se encontra intrinsecamente vinculada à crítica urbana realizada pelo grupo situacionista no final dos anos 1950 e início dos anos 1960, ao processo de espetacularização das cidades ${ }^{17}$.

Esta discussão sobre os processos de formação de uma "cultura do espetáculo" foi iniciada por Debord em A Sociedade do Espetáculo ${ }^{18}$, em que constrói uma reflexão crítica sobre os movimentos da sociedade capitalista. Debord diz:

O espetáculo na sociedade corresponde a uma fabricação concreta da alienação [...] A alienação do espectador em favor do objeto contemplado (o que resulta de sua própria atividade inconsciente) se expressa assim: quanto mais ele contempla, menos vive [...] É por isso que o espectador não se sente em casa em lugar algum, pois o espetáculo está em toda parte" (DEBORD, 2016, p. 24).

É possível perceber o tom denunciativo com que Debord discorria sobre esta noção de espetáculo, pois estava intensamente influenciado pela energia dos movimentos de esquerda, que, neste período, organizavam-se na Europa e culminaram com os múltiplos eventos de Maio de 1968. Tendo esta noção de espetáculo em vista, a crítica urbana situacionista era direcionada, sobretudo, ao pensamento do urbanismo modernista, hegemônico nesta época, que operava numa lógica racional e funcional, tendo-a como pilar de sua construção enquanto

\footnotetext{
17 “a irônica crítica urbana situacionista parece ainda tão atual exatamente por ter atacado, dentro do contexto europeu dos anos 1950-60, os primórdios dessa nova espetacularização contemporânea" Cf. JACQUES, 2003, p. 14.

${ }^{18}$ Do título original La Société du Spetacle: Comentaires sur la société du spetacle publicada em 1967.
} 
disciplina. Assumiam, assim, um viés intensamente político na sua construção enquanto grupo.

Neste sentido, os situacionistas, que tinham como membros Guy Debord, Asger Jorn, Constant, Gilles Ivain, Christian Dotremont, dentre outros, estavam mobilizados contra esta lógica do urbanismo que predominava nas grandes cidades do Pós-Guerra e propunham o urbanismo unitário (UU), definido como uma noção que:

[...] Opõe-se ao espetáculo passivo, típico de nossa cultura, no qual a organização do espetáculo se estende de forma tanto mais escandalosa visto que o homem pode cada vez mais interferir de várias maneiras. Enquanto hoje as cidades se oferecem como um lamentável espetáculo, um anexo de museu para turistas que passeiam em ônibus envidraçados, o UU vê o meio urbano como um terreno de jogo do qual se participa. O urbanismo unitário não está separado do atual terreno das cidades. É formado a partir deste terreno e das construções existentes. Deve tanto explorar os cenários atuais, pela afirmação de um espaço urbano lúdico tal como a deriva o reconhece, como construir outros, totalmente inéditos [...] O urbanismo unitário não aceita a fixação das cidades no tempo (TEXTO COLETIVO, 1954, p. 100).

Identifico nesta colocação de Debord aspectos importantes a serem discutidos da crítica situacionista. O primeiro deles se refere a esta ação no terreno atual das cidades. Nas deambulações há esta ação, no sentido de que elas são afetadas pelos fluxos e forças produzidos no ambiente urbano. No entanto, elas acontecem com o intuito central de engoli-lo, de negá-lo, de embaçar tais movimentos de atualização, que nele acontecem, através de um modo de operar maquinado pela embriaguez dos sentidos e pelo estranhamento. Nas derivas identifico um reposicionamento no que se refere a este modo: elas permitem o reconhecimento afetivo de oportunidades para construir novos cenários, conforme eles colocam "totalmente inéditos", utilizando-se destes preexistentes na cidade. Não há a intenção de negar, como na deambulação, trata-se exatamente da possibilidade de abertura para outras relações entre os corpos e objetos, para os devires e possibilidades de produção ativa e lúdica de novas situações urbanas.

O outro aspecto se refere à "não aceitação" da fixação das cidades no tempo. Nas deambulações identifico esta postura operando na chave da inserção dos movimentos do inconsciente que acontecem na cidade e, em si mesmo, através do estranhamento. A “agenda" deambulatória está vinculada à produção de embriaguez com o movimento da cidade provocada pelo estranhamento e pela fugacidade (JACQUES, 2014, p. 139). Nas derivas, há novamente um 
reposicionamento frente a este aspecto: há um movimento de abertura aos afetos que a cidade promove, no entanto como forma estudá-la, de entender de que forma suas sobrevivências poderiam construir situações novas no ambiente urbano.

Tendo em vista estes aspectos, que mostram como estas duas errâncias lidam de forma diferente com questões que partem de uma mesma matriz crítica, há um reconhecimento de duas noções, desenvolvidas pelos situacionistas e importantes para entender a maneira de se relacionar com as sobrevivências: a participação e o jogo.

Primeiramente, a noção de participação estava, no caso dos situacionistas, vinculada à ideia de construção de situações. Segundo Jacques, "o pensamento urbano-situacionista seria então baseado na ideia de participação e de revolução da vida cotidiana através da construção de situações" (JACQUES, 2014, p. 219). Esta construção de situações seria a possibilidade de uma transformação revolucionária da vida cotidiana nas cidades, expurgando o caráter disciplinador e funcionalista que o urbanismo e o planejamento urbano vinham imputando às cidades.

Sobre a noção de jogo, é possível identificar, a partir da fala de Debord no texto de abertura da revista Internacional Situacionista, Relatório sobre a construção de situações, a sua relevância para o pensamento situacionista, assim, para a prática da Deriva:

Nossa ação sobre o comportamento, ligada a outros aspectos desejáveis de uma revolução de costumes, pode ser definida sumariamente pela invenção de jogos de novo teor. O objetivo mais geral deve ser de ampliar a parte não medíocre da vida, de diminuir-lhe ao máximo momentos nulos. [...] O jogo situacionista se distingue do conceito clássico de jogo pela negação radical de aspectos lúdicos da competição e de se separação da citada corrente. Ao contrário, o jogo situacionista não aparece distinto de uma escolha moral, que é a opção por tudo o que garante o futuro reino da liberdade e do jogo (DEBORD, 2003, p. 55-56).

O teor revolucionário que o jogo traz para os situacionistas ajuda a identificar a potência que a deriva possui para pensar possibilidades de atualização a partir dos restos ao longo destes muros do ramal ferroviário Santa Cruz. Na medida em que parte do pressuposto de uma ação revolucionária sobre os costumes, sobre os "comportamentos" hegemônicos, traduzo-a como uma ação em direção ao reconhecimento de sobrevivências e, uma vez encontradas, produzir formas de jogo para ativação das mesmas. 
Quando me refiro a esta produção de formas de jogo, entendo que isto pode se dar, sobretudo, na construção das narrativas das derivas realizadas. O jogo pressupõe a montagem de determinadas "regras" que, uma vez feitas, possibilitam a ação de jogar. Assim como apontava Benjamin quando entendia que o problema da experiência urbana não estava em sua efetuação na cidade em si, mas sim em sua transmissão, os situacionistas transpunham estas noções de participação e jogo para suas narrativas a partir de mapas cartográficos, realizados como cartografias subjetivas, afetivas, fragmentos de texto, desenhos, citações e indicações. Tais narrativas tinham o objetivo de aproximar-se, ao máximo, dos afetos e "alisamentos" que a deriva mobiliza.

É possível perceber estes mapas cartográficos em duas obras mais conhecidas: A primeira é The Naked City, illustration de l'hypothése des plaques tournantes (1957) de Debord:

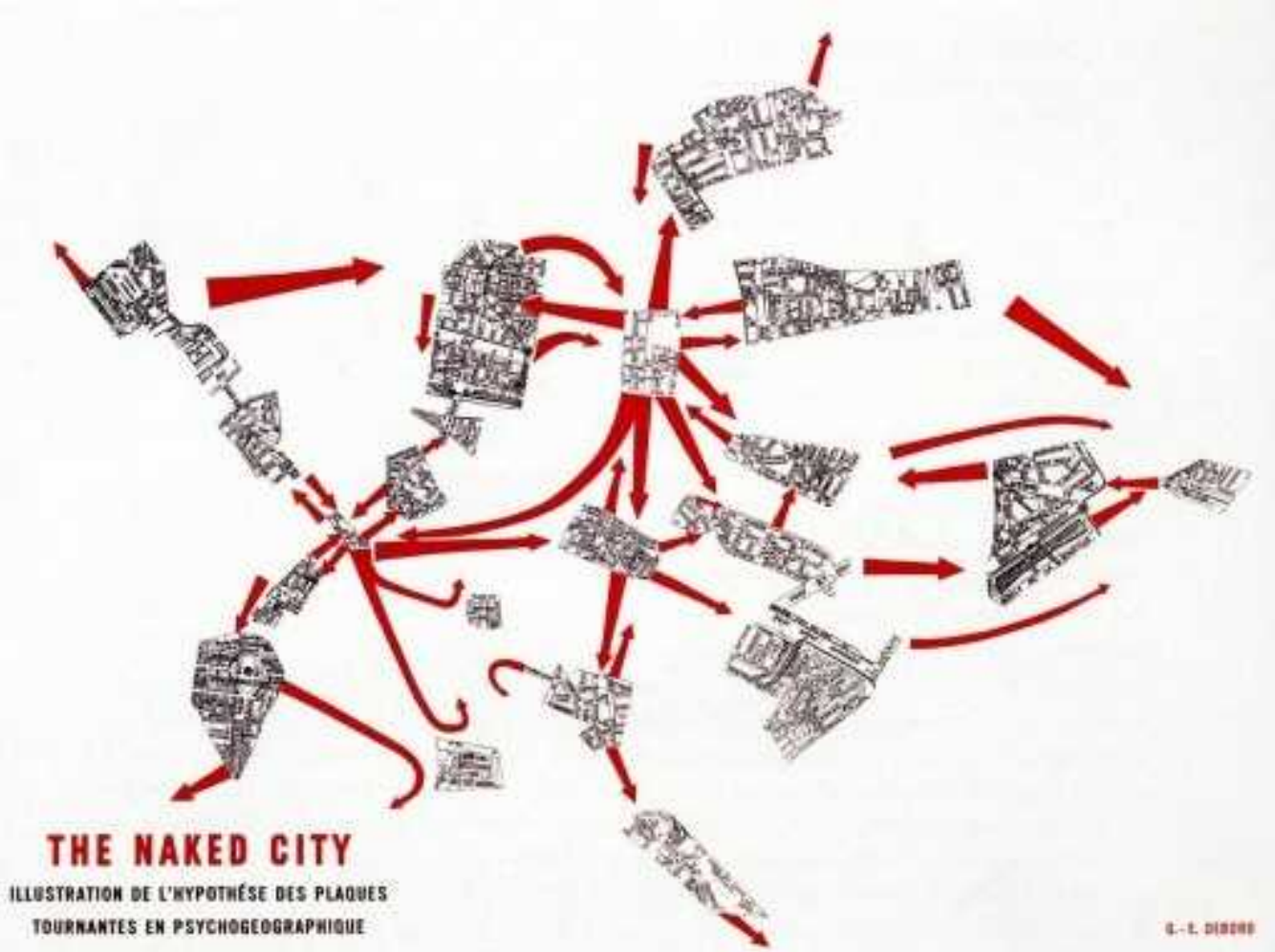

Figura 17. The Naked city, illustration de l'hypothése des plaques tournantes de Guy Debord, 1957.

Estes fragmentos são áreas da cidade de Paris que foram recortadas de um mapa de acordo com os efeitos psicogeográficos que foram gerados durante a deriva, independentemente de suas definições enquanto bairros ou regiões administrativas. Assim, foram localizados de forma que pudessem ser mostradas 
as suas ligações afetivas, seus níveis de intensidade, que são representadas através dos diferentes tamanhos de setas vermelhas.

Existe, a meu ver, notoriamente, uma ligação com a ideia de "alisamento" do espaço de Deleuze e Guattari. Este mapa cartográfico poderia se expandir ao infinito, importando, sobretudo, as setas que conectam estes fragmentos, que são as linhas de natureza direcional do espaço liso deleuze/guattariano, seus trajetos e suas intensidades.

A segunda é o Map of Venise (1957) de Ralph Rumney, que é uma fotocolagem fruto de Derivas de Ralph Rumney na cidade de Veneza:

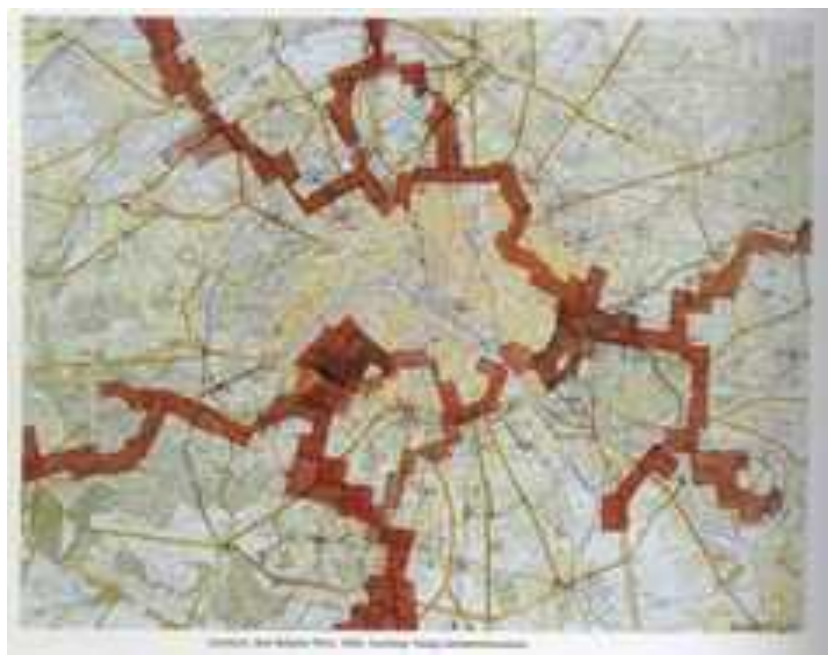

Figura 18. Map of Venise de Ralph Rumney, 1957.

Neste caso, o modo de cartografar foi marcando com diferentes intensidades as ambiências atravessadas na errância. Tal prática mostra o "alisamento" do mapa da cidade de Veneza na medida em que conecta espaços que não se conectam fisicamente, mas afetivamente, fazendo com que infinitas possibilidades possam surgir, a depender de que prática a experiencie.

Já no Brasil, a reverberação destas ideias situacionistas nos apresenta um outro "arrastamento" através da prática Delirium Ambulatorium e de sua associação à obra Parangolés do artista Helio Oiticica.

O artista realizou o Delirium Ambulatorium em inúmeras cidades, sobretudo no Rio de Janeiro. Esta expressão já atravessava as conversas e cartas que o artista tinha com seus amigos, principalmente quando começou a frequentar as periferias do Rio de Janeiro - em especial o morro da Mangueira - quase diariamente. Oiticica diz: 
Eu descobri o seguinte, a relação com a rua com o que eu faço é uma coisa que eu sintetizo na ideia de DELIRIUM AMBULATORIUM. O negócio assim de andar pelas ruas é uma coisa que, a meu ver, me alimenta muito e eu encontro. $\mathrm{Na}$ realidade, a minha volta ao Brasil foi uma espécie de encontro mítico com as ruas do Rio, um encontro mítico já desmitificado. Antes dos anos 60, foi a construção da mitificação da rua, mitificação da dança, da Mangueira. Agora é um processo de desmitificação, junto com a mitificação, uma coisa vem junto da outra (OITICICA apud JACQUES, 2014, p.176).

É possível perceber que esta prática era entendida pelo artista como a construção de uma experiência de alteridade urbana. Os processos de mitificação e desmitificação da rua, da dança e da Mangueira, que passaram pelo fato de o artista ter sido passista da Escola de Samba desta comunidade, tornar-se amigo dos bandidos míticos da época e explorar este local tão mítico para a cidade, podem ser entendidos como uma construção de aberturas para os devires urbanos, para outras formas de experimentação corporal da cidade, sobretudo nas suas interlocuções com o corpo e as sobrevivências que eram encontradas nestes percursos erráticos.

Jacques diz que o artista praticava derivas e caminhadas criativas na cidade (JACQUES, 2014, p. 174). No entanto, é possível reconhecer dois aspectos do Delirium Ambulatorium que misturam tanto a prática de deambulações quanto a de derivas: (1) sua identificação com uma condição corporal de estranhamento, de deslocamento muitas vezes para os movimentos inconscientes do corpo, assumindo um viés "etnográfico surrealista" em suas anotações ao errar pela cidade; (2) sua postura clara de inserção, de participação, sobretudo na comunidade da Mangueira, construindo situações, cartografias subjetivas e afetivas de forma a abrir-se para a produção de devires neste ambiente urbano.

Este tipo de errância urbana, que se encontra em uma condição Entre a deambulação e a deriva, que fez o artista refletir sobre estes corpos que ocupavam as zonas de subúrbio da cidade, as escolas de samba; eram os corpos do improviso, do descontrole, do delírio e do prazer, fato que resultou em sua obra Parangolés. O artista montava inúmeras capas com tecidos em tamanhos diversos, como fragmentos, restos encontrados, que qualquer pessoa poderia vestir e circular pelo ambiente urbano. As noções de participação e jogo são intrínsecas à obra, uma vez que o importante era vesti-la e experimentá-la da forma que quisesse. Jacques, ao investigar a arquitetura das favelas através da obra do 
$\operatorname{artista}^{19}$, levanta a noção de fragmento como forma de construir uma reflexão acerca dos Parangolés. Ela diz, "o fragmento constitui um mundo à parte, um sistema autônomo difícil de ser captado, mas não totalmente fechado em si: o que o cerca é transponível, porque inacabado. Um paradoxo” (id., 2003, p. 46).

Ao incorporar o paradoxo como um nó fundamental para pensarmos a complexidade destas experiências corporais urbanas, Oiticica não somente expõe as linhas de estratificação que compõem os múltiplos dispositivos urbanos nos quais atua (como a favela, as ruas, os ônibus, os museus, etc.), mas sobretudo mostra as linhas de atualização que podem ser criadas neles através da forma com que constrói suas narrativas (corporais e literárias): abertas às incompletudes, ao que as sobrevivências encontradas nos trajetos podem produzir de reflexão sobre a cidade e, intensamente, transponíveis a outros modos de experimentação urbana.

Transpondo esta discussão para o dispositivo muro do ramal ferroviário Santa Cruz, penso que é possível reconhecer nesta prática do artista a potência de geração de outras linhas de força neste dispositivo através do ato de construir as narrativas e, desta forma, produzir suas atualizações.

Este muro configura estratos bem definidos no interior da ferrovia que produzem espaços restantes, restos urbanos. Mesmo que ele seja invisibilizado enquanto dispositivo, sua capacidade de aprisionamento, de corte de fluxos urbanos, de manutenção do abandono é flagrante quando percebo mais atentamente estes locais. Neste sentido, a prática da deriva, entendida com todos os seus arrastamentos da deambulação, parece ser uma forma de produzir outros movimentos nestes locais, através de sua operação de construção afetiva, participativa e lúdica com as sobrevivências encontradas no espaço urbano. Sua capacidade de abrir-se aos fluxos e forças do espaço atentando-se para o que os afetos por estas sobrevivências podem construir, mesmo que em pequenos e trêmulos lampejos, parece ser uma forma de engendrar atualizações neste dispositivo muro.

A busca de uma problematização da função de proteção de tais muros através da deriva, configura-se como uma operação na condição Entre: é uma via de apreensão e compreensão que opera a partir da alteridade, gerada pelo afeto e ativação de sobrevivências, num espaço estabelecido Entre termos, isto é, num

\footnotetext{
${ }^{19}$ A autora realiza esta pesquisa em seu livro Estética da Ginga: A arquitetura das favelas através da obra de Hélio Oiticica.
} 
espaço de movimento entre os muros e a ferrovia. Neste caso, a narrativa que será apresentada se configura como outra escrita afetiva e poética, que desdobra a situação de enclausuramento que o limite deste muro gera aos espaços internos a ferrovia, entendendo-a como uma via de luta, mesmo que surda, por novas luminosidades ao longo destes muros, como diz Ana Clara Torres Ribeiro:

Existem, no presente, uma nova efervescência e um novo ativismo que, mesmo inoculados pela ação dominante, admitem diferentes apropriações e outros sentidos. Afinal, não se interfere gratuitamente no tecido urbano. Aparecem novas luminosidades [...] que modificam cenas, cenários, cenografias e personagens. Essas luminosidades correspondem a uma luta surda por virar acontecimento, que cada vez mais se articula à luta pela sobrevivência. Por que desconhecer essa luta surda e a força do acontecimento? (RIBEIRO, 2010, p. 39)

\subsection{Restos sobreviventes: atualizações no Engenho Novo}

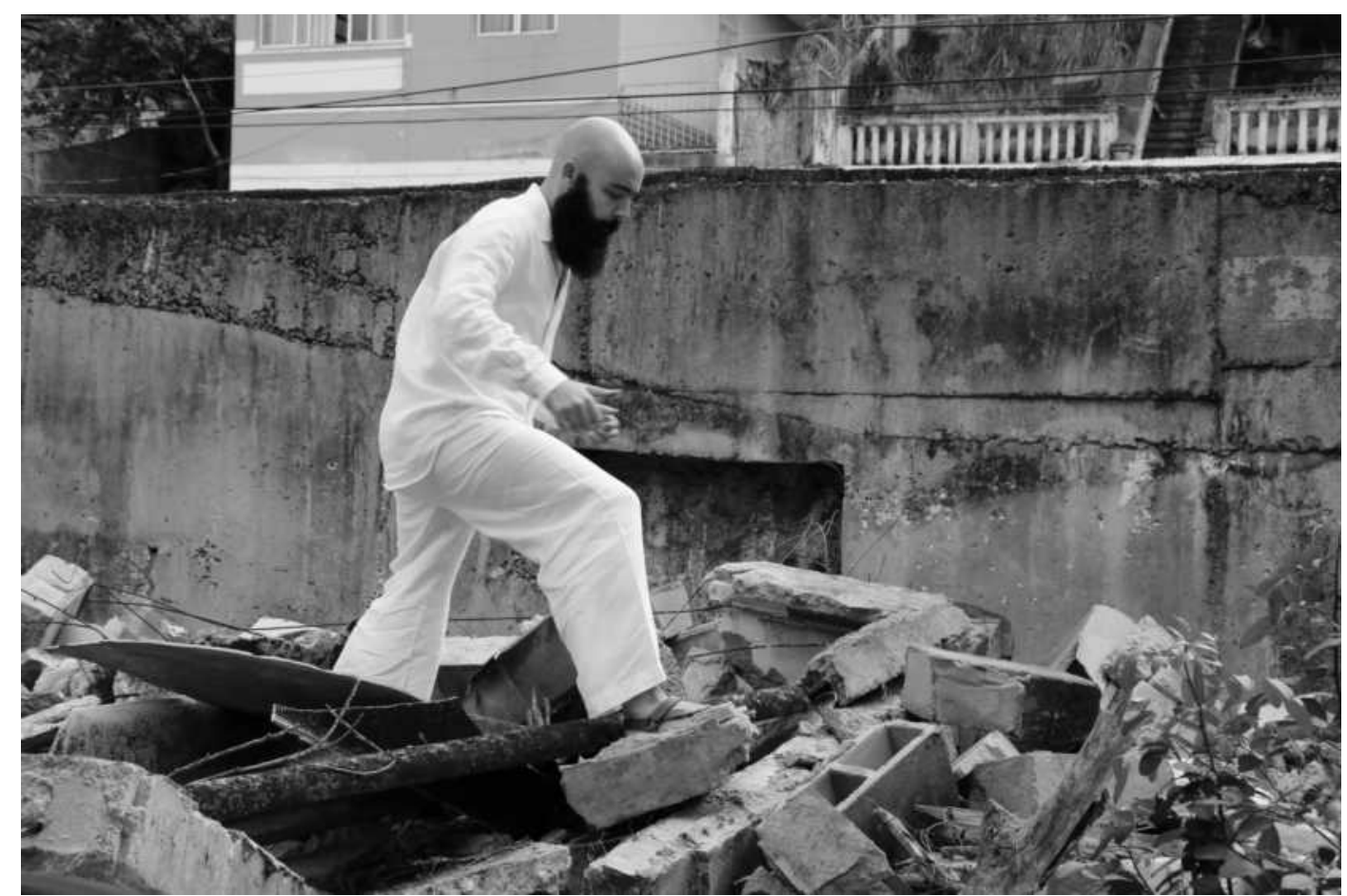

Figura 19. Derivar no meio. Engenho Novo, Rio de Janeiro.

Pensei antes de pisar na calçada de frente à minha casa que a sandália que calcei estava levemente larga. Será que iria aguentar todo o percurso? No segundo seguinte, senti que ela, com certeza, sabe mais dos meus caminhos do que a minha mente poderia formular, pois me acompanha por toda a cidade, sente todo o resto, buraco, desnível, poça d’água, poeira, diretamente em sua superfície. Adapta-se e 
arrasta consigo todos estes contatos. Voltei logo a estar bem com a sua forma de sobreviver nos meus pés: leve, flexível e resistente assim como todos os elementos que pisa. Pisar. Mover.

Curiosamente, eram estas palavras que me moviam ao colocar-me próximo aos muros do ramal Santa Cruz.

Leveza, flexibilidade e resistência.

Uma produção afetiva diante do que o muro provoca nestes trechos da cidade. Meu corpo convoca as energias do vento em busca de luzes trêmulas, como DidiHuberman, por dentro dele, vagalumes escondidos nas florestas muradas da ferrovia. "É um tempo em que os conselheiros pérfidos estão em plena glória luminosa, enquanto os resistentes de todos os tipos, ativos ou passivos, se transformam em vagalumes fugidios tentando se fazer tão discretos quanto possível, continuando a emitir seus sinais [...] Quanto às lucciole [pequenas luzes], elas tentam escapar como podem à ameaça, à condenação que a partir de então atinge sua existência" 20 .

Na dúvida. Por onde seguir?

Pegar o trem.

Assim o fiz.

Entrar no trem.

Naturalmente fui para a porta e meu olhar fixou-se na janela, onde é possível ver os muros por dentro da ferrovia. Como eu poderia evitar o pensamento de derivar nestes espaços? Eles chamavam-me.

Engenho Novo. O Novo. Parecia-me novo mesmo. Sentia como novo. Experimentar seus cacos, seus quebrados, a exposição de suas entranhas, de seu "des-engenho".

A plataforma estava vazia e a oportunidade de pular nos trilhos se deu.

Invadir a ferrovia.

Correr em direção aos espaços que margeiam o muro.

Antes de continuar, pensei em Solà-Morales: "Exteriores mentais no interior físico" ${ }^{21}$. E ainda em suas bordas, parei e me vi diante de outros tempos, fato que me fez segurar o corpo e respirá-los. Entrar em contato.

\footnotetext{
${ }^{20}$ Cf. DIDI-HUBERMAN, 2014, p. 17.

${ }^{21}$ Cf. SOLÀ-MORALES, 2002, p. 188.
} 
Espaço amplo, o sol batia no rosto como se dissesse que eu precisaria de luz, fogo e calor para enxergar as pequenas luzes deste espaço.

Ofuscação. Brilhar. Solar. O sol. Suor.

Esperar as nuvens.

"à ordem uma vida de risco"22. Alguns trens passavam pelas minhas costas anunciando movimentos de risco, de corte e fuga.

O muro desliza como guarda e proteção destes espaços de anacronia na cidade. Como pode não ser também isto? Como ele continua de pé? Como sobrevive? Minha mente voa observando o muro que se encontra ao fundo destes espaços. O que é sobreviver nestes locais? Perguntas que me invadem e me fazem agachar, pegar o papel e o lápis que levei comigo no bolso e no primeiro pedaço de concreto, escrever:

Seleção das ações de sobrevivência:

Separar - Juntar

Desconectar - Conectar

Cortar - Colar

Impedir - Deixar

Limitar - Permitir

Esconder - Encontrar

Travar - Expor

Segurar - Soltar

Aprisionar - Libertar

Fechar - Abrir

Esquecer - Lembrar

Descartar - Usar

Romper - Fluir

Rasgar - Unir

A partir desta escrita senti por onde partir. Sol. Como peças ou gatilhos para a construção de situações de jogo, evocando a produção de memórias inconscientes a partir do que seria encontrado no caminho, estas ações vieram.

Vento. Nuvens. Nuvens-alívio. E o vento me deu sinal: Sair da borda.

${ }^{22}$ Idem, ibid. 
O caminho não estava traçado previamente, segui por cima de escombros que me fizeram encontrar um mar de ferragens, arames farpados e ferros retorcidos.

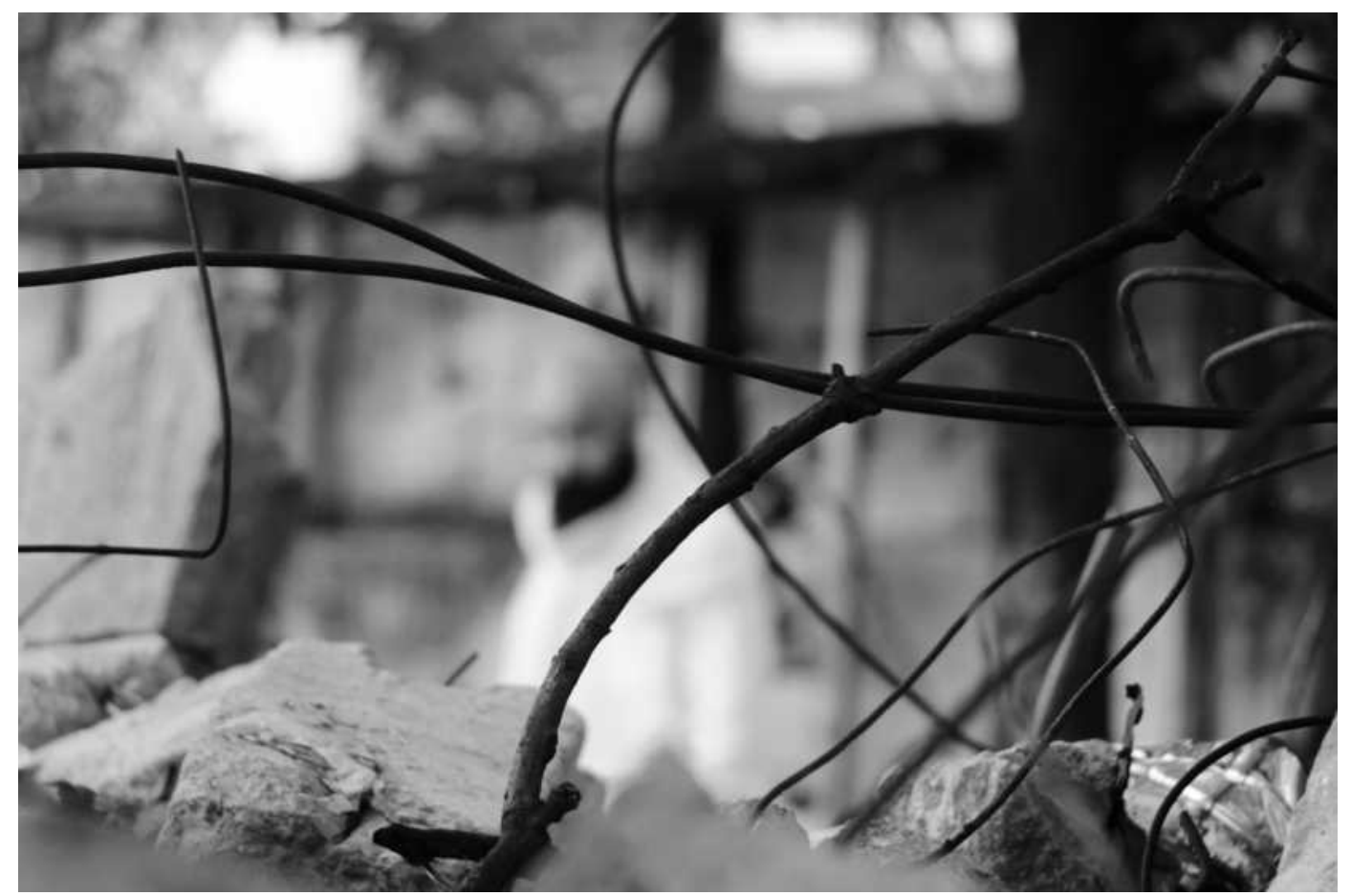

Figura 20. Vergalhões. Engenho Novo, Rio de Janeiro.

Descobri que estavam vivos. Arranhão. Perna. Um aviso de que queriam ser vistos.

Dobrar no espaço. Dobras do espaço. O espaço dobra quando eles arrastam entre si as pedras, o ar e os ferros em um contorcionismo infinito que o meu corpo reproduz para se equilibrar em cima dos escombros. Seriam estas as belas entranhas daquele que a esconde da cidade? É tanto movimento que o sangue tinha que aparecer. $\mathrm{O}$ espaço me feriu como o corpo o estava ferindo. E aonde estaria o sangue dele?

$\mathrm{Eu}$ estava no próprio sangue, neste mar de restos murados pulsando outras temporalidades a serem navegadas. Com o arranhão ardendo, me senti vivo e ultrapassei a montanha de escombros.

Um portão. Vou ao seu encontro.

Muros feitos de restos de passagens que um dia foram ativas. Agora: uma corrente e um cadeado.

Muros de pé, acorrentados.

Pensei em quantas correntes nos amarram a certos modos de existência, que nos impedem de transitar, de se afetar e mudar com este afeto. 
Estas correntes me levaram para este lugar, para a urgência de reposicionamento do meu corpo através de táticas que quebrem os cadeados, que assumam o conflito. Não quero correntes e, assim, disputo por suas quebras.

Viro para o lado e vejo um objeto afundado na terra.

Desenterrar: encher de ar.

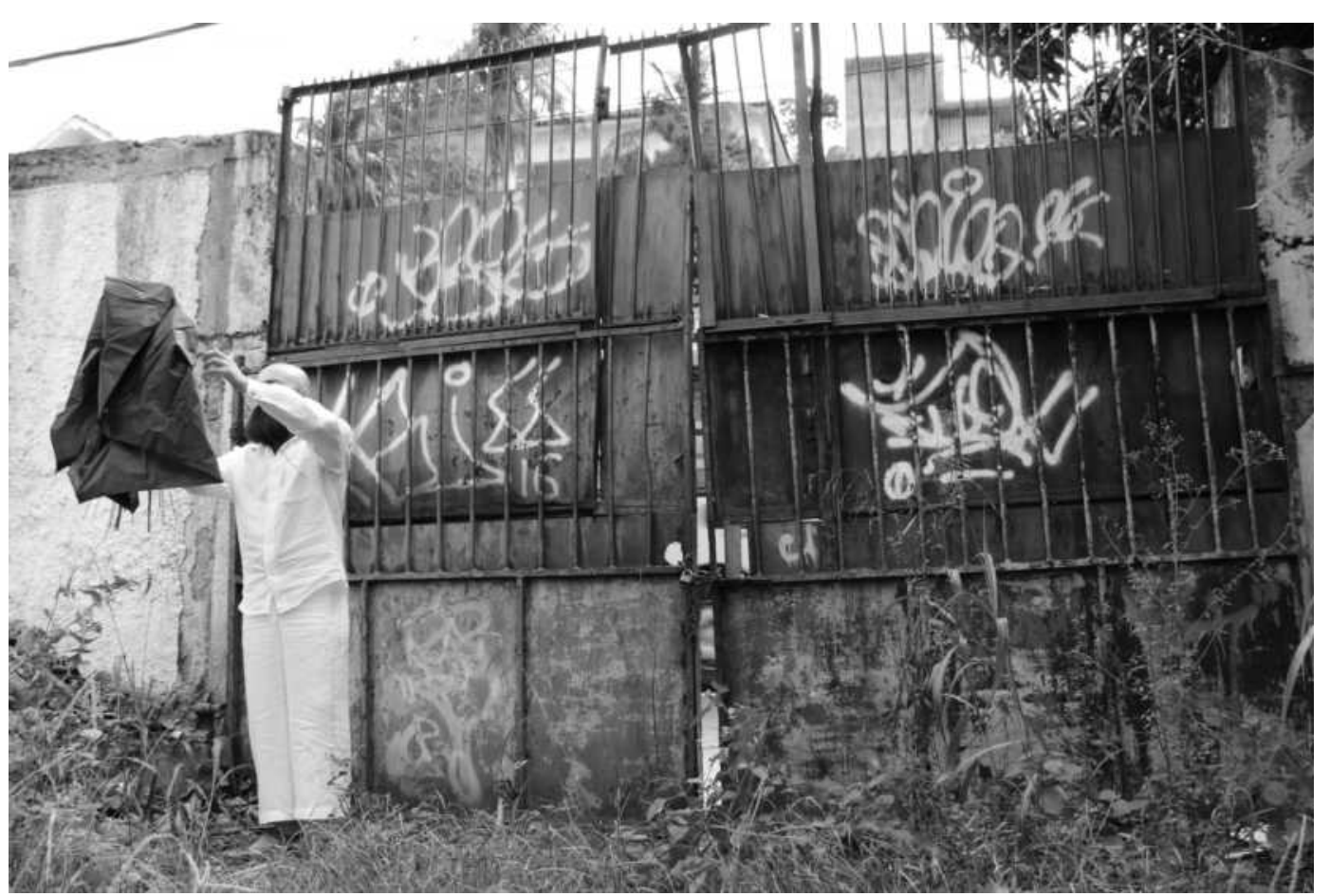

Figura 21. Guarda-chuva. Engenho Novo, Rio de Janeiro.

Ele abriu-se e me fez perceber que eu estava com sede. Nuvens. Cinza. Azulado.

Quantos deste poderiam estar por ali? Será que ainda funcionava?

Muros não protegem da chuva, nem do vento, nem da lama.

Talvez essa fosse a razão de ele estar ali, jogado na terra, apreendendo dela as energias telúricas da resistência, da transformação.

Percebi que para apreender mais deste chão, poderia experimentá-lo de outras formas. 


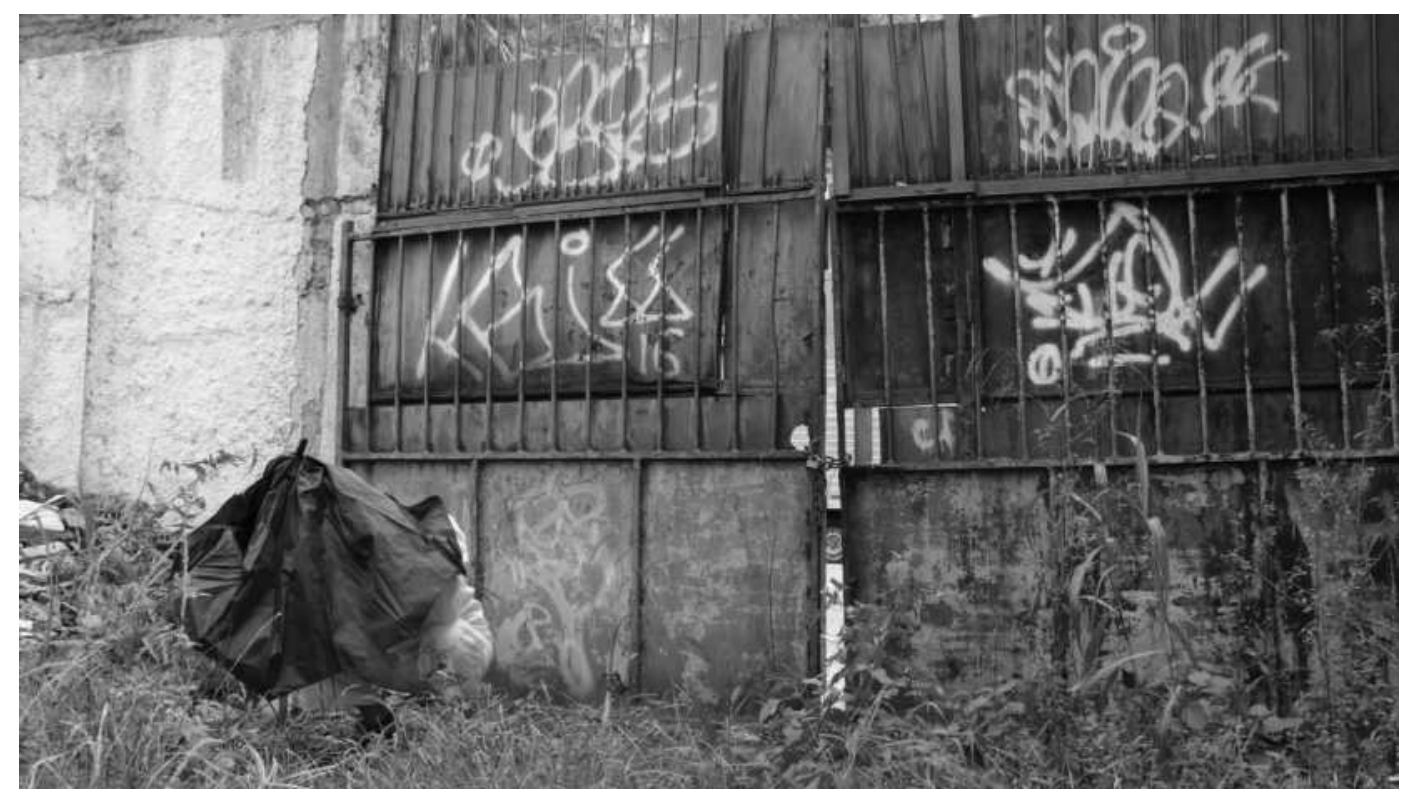

Figura 22. Escurecendo o chão. Engenho Novo, Rio de Janeiro.

Ver a grama nascendo ao lado de tamanho impedimento que os muros causam é vê-lo guardando vida. Olhar para o chão sob esta cobertura: escurecer.

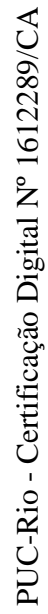

Sentia que estas sobrevivências me mostrariam algo sobre o paradeiro dos vagalumes. Neste canto, foi possível ter acolhimento, sentir que o ar se encontrava com a terra e com a água que me faltava na boca. Guarda-chuva que ainda cheira a água. Será que os muros guardariam água em algum lugar ou são só pedra, concreto e ferro seco?

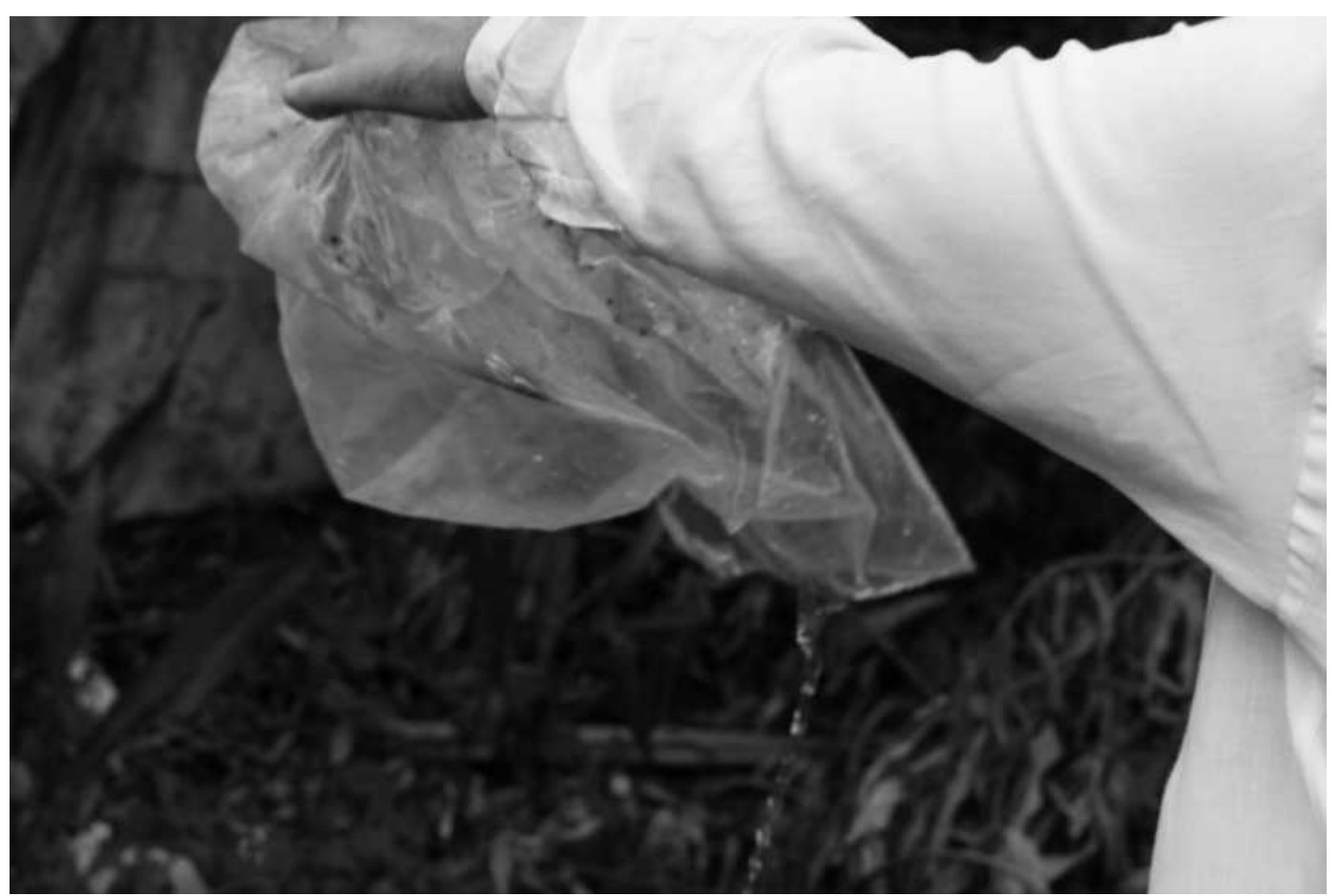

Figura 23. Saco plástico. Engenho Novo, Rio de Janeiro. 
Água acumulada em sacos plásticos presos na terra murada para mim também é muro. Achei água nos muros e o jogo é libertá-las. Água presa me faz mal.

Assim o fiz.

Conectado com o vento. Continuar a caminhar próximo ao muro.

Os trens passavam em tempos ritmados nestes locais, lembrando que eu estava em territórios de risco. No entanto, exatamente este risco alimentava o meu desejo de estar ali. Aprendi com a minha sandália a sentir melhor os movimentos do chão e com o guarda-chuva, a aferir a minha visão para as pequenas luzes movimentando-se pela terra.

Sigo leve.

O tropeçar é como dar-se conta da presença do vazio no e do corpo, e de sua completa infantilidade. Como o titubear. É uma espécie de lançamento de dúvida no caminho. "O interessante da lógica fragmentária é precisamente a problematização pela dúvida. Não há qualquer possibilidade, nem interesse, de se buscar uma lógica unitária. A questão também é temporal, diz respeito a uma ordem incompleta e mutável, mas o inacabado, a ausência de um conjunto, de uma totalidade, também incita a exploração, à descoberta, o que os fragmentos têm de incompleto, de inacabado, possibilita também outras associações, em particular a partir do intervalo (o vazio que os separa) entre eles"23.

Aprendi isto passando mais rápido sobre raízes de árvores e descobrindo uma estrutura de madeira que deitava neste local.

\footnotetext{
${ }^{23}$ Cf. JACQUES, 2015, p. 52.
} 


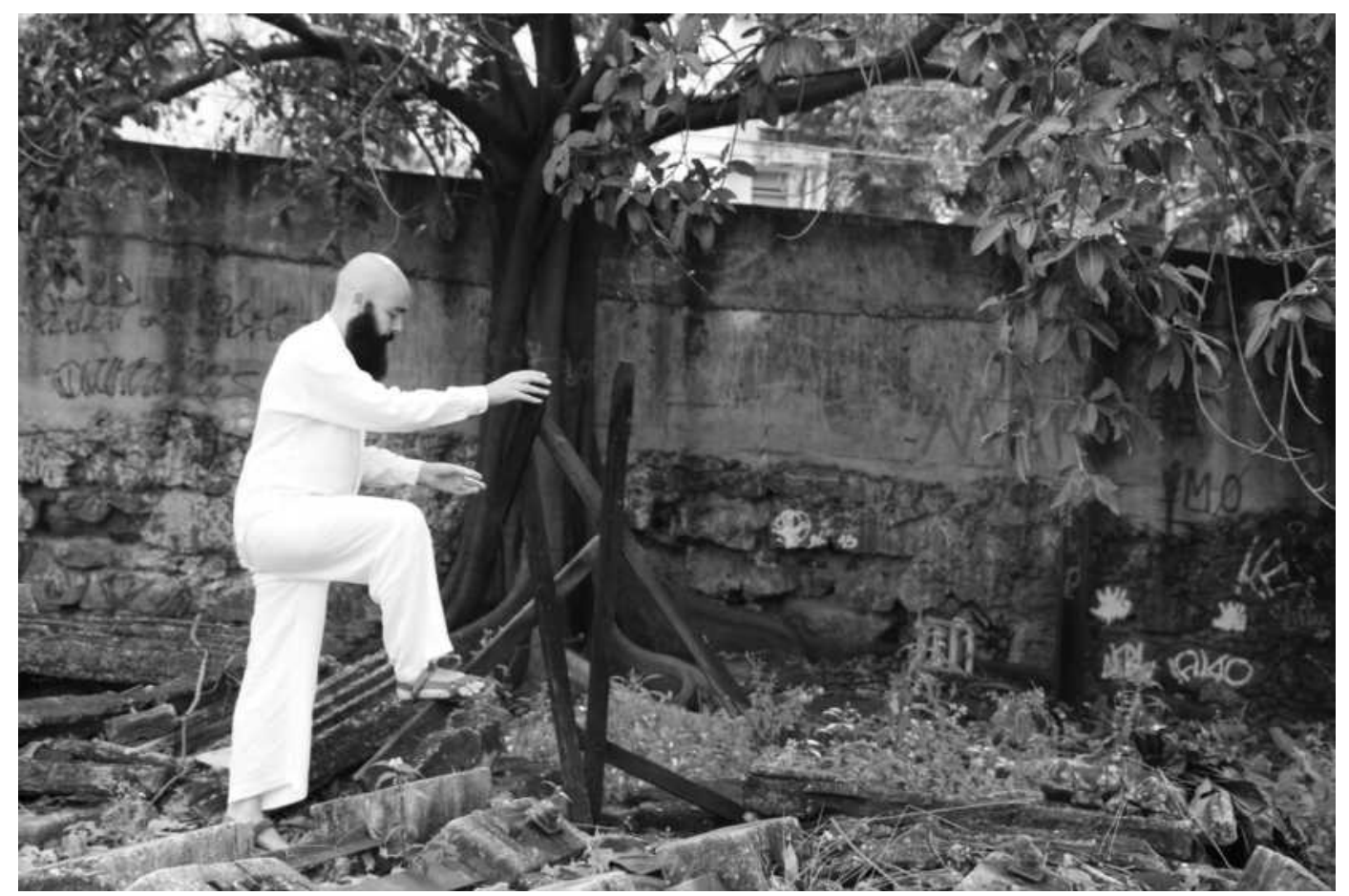

Figura 24. Estruturas de madeira, Engenho Novo, Rio de Janeiro.

Madeira. Calor. Nós.

Estava abafado mesmo, mas a madeira, mesmo estando húmida, trouxe-me esta sensação.

A dobra que esta estrutura provocava no espaço ao ser levantada me fez pensar em como, na medida em que eu me desloco para entender a estrutura, o espaço a invade. E esta só existe enquanto objeto nesta experiência de deslocamento. "Se o futuro é ultrapassado e fora de moda, então estive no futuro. Estive em um planeta que tinha desenhado sobre ele, um mapa de Passaic, e um mapa bastante imperfeito [...] A qualquer momento meus pés estavam aptos a cair através do chão de papelão. Estou convencido de que o futuro está perdido em algum lugar nos depósitos de lixo do passado não histórico [...] o tempo transforma as metáforas em coisas e as guarda em depósitos frios ou em playgrounds celestiais dos subúrbios" (traduzido por mim) ${ }^{24}$.

Me senti desta forma com esta estrutura de madeira, só que o futuro não apontava para lugar algum, estou produzindo-o.

\footnotetext{
24 "If the future is "out of date" and "oldfashioned" then I had been in the future. I had been on a planet that had a map of Passaic drawn over it, and a rather imperfect map $t$ that. At any moment my feet were apt to fall through the cardboard ground. I am convinced that the future is lost somewhere in the dumps of the non-historical past [...] Time turns metaphors into things, and stacks them up in cold rooms or places them in the celestial playgrounds in the suburbs" Cf. SMITHSON, 1996, p. 73-74, grifo do autor.
} 
Joelhos bambeando. Levantá-la. Sentir seus detalhes. Encontrar suas temporalidades. Expor suas fragilidades de sustentação.

Quais seriam as fragilidades destes muros?

Mais uma vez, o vento: são estas, nas suas mãos. Deixar no chão. Seguir.

Olhei uma última vez, pensei na fragilidade e na potência dos vagalumes e deixei a estrutura no chão.

Tinha sede e o tempo fechou.

Engoli a saliva.

Joelhos, braços e pescoço. Bambear. Leveza.

Olhar aferido aos detalhes.

Deixei-me levar pela relva que iria para perto do muro e avistei algumas coisas:

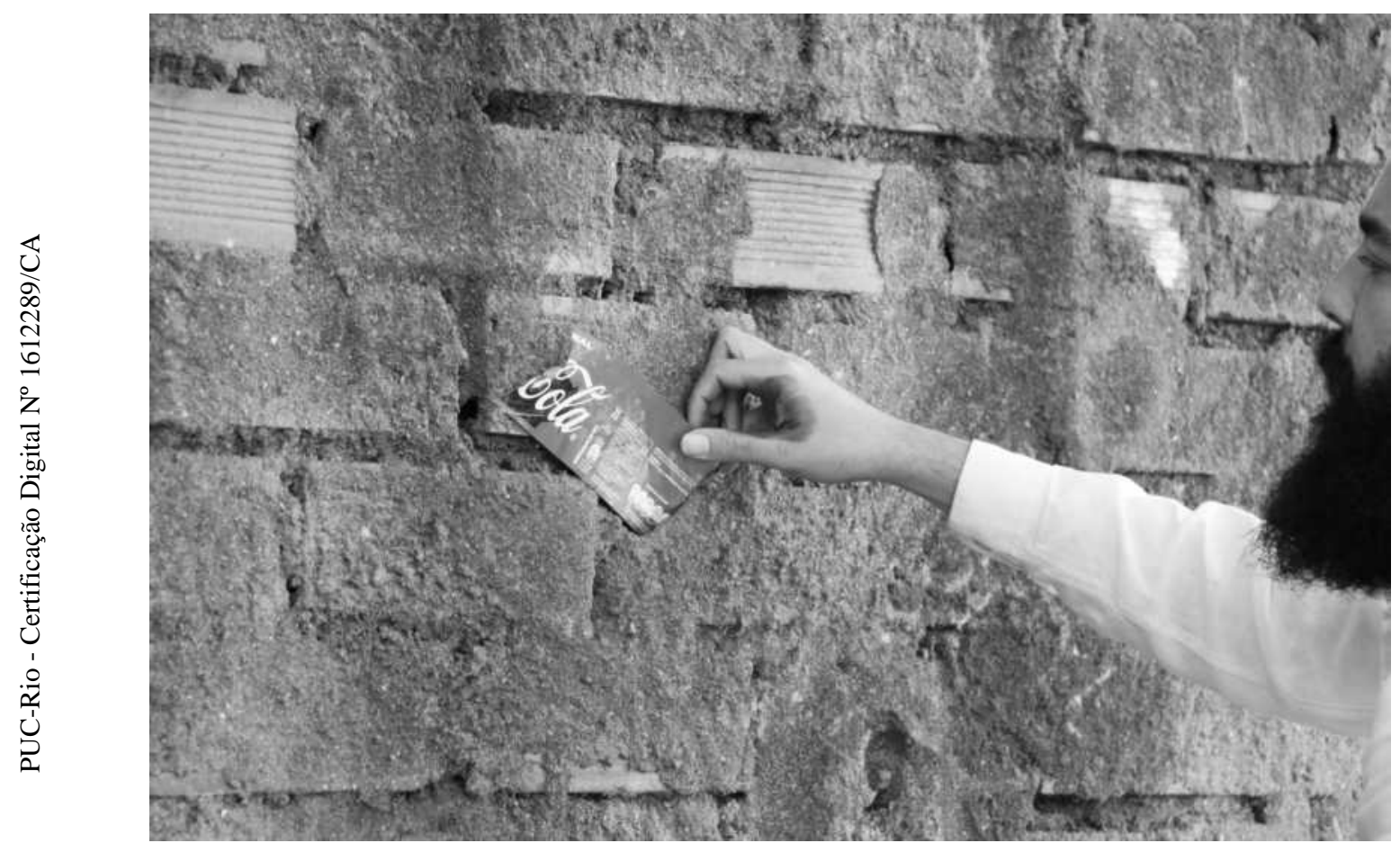

Figura 25. Embalagem de Coca-cola, Engenho Novo, Rio de Janeiro.

Coca-cola: expurga as bactérias do corpo. Limpa e mata o corpo. Minha vontade foi de colar a embalagem nos muros, devolver à sua concretude o poder de expurgação inerente ao líquido industrializado, mas não das bactérias do corpo, e sim de seu controle. Controlar. C-o-n-t-r-o-1-a-r. D-C-o-n-t-r-olar. Des-C-o-n-t-ro-l-a-r. Descontrolar. 


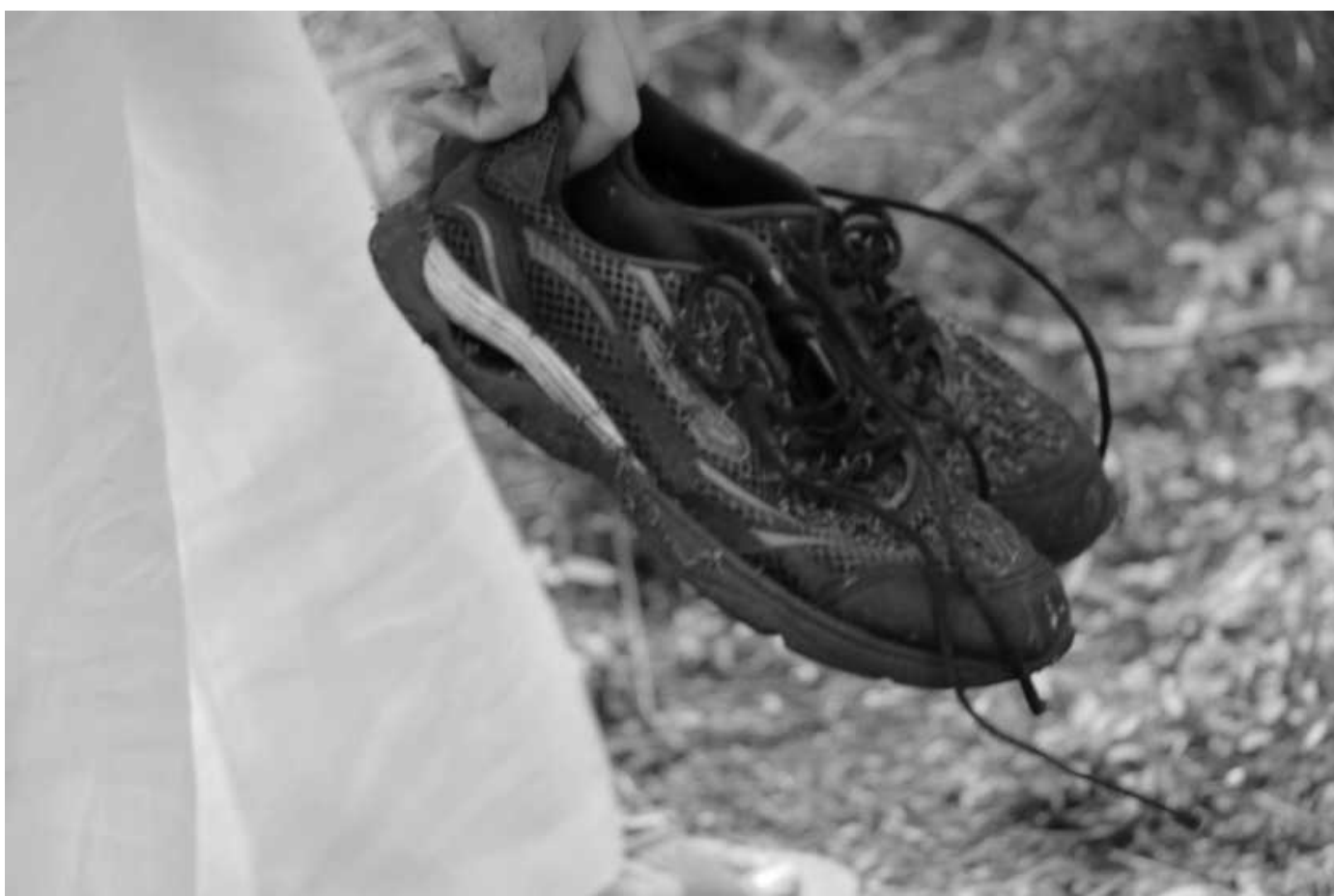

Figura 26. Tênis, Engenho Novo, Rio de Janeiro.

Um par de tênis: esconde o corpo das bactérias. Protege e mata o corpo. Minha vontade era de juntar os dois e mostrar a sua inutilidade. Lembrei na hora da minha sandália e em como ela permitia que os meus pés se machucassem. As cascas de árvore que Didi-Huberman recolheu em Birkenau eram machucadas pelo tempo, inteiramente marcadas, e isto as fazia vivas. A lógica da proteção produz isolamentos, encastelamentos e assepsias na cidade.

O par de tênis é muro, pois reproduz, mesmo que precariamente, esta lógica e isto afetava o meu coração e os meus pés.

Caminhar. Ouvir o vento: deixá-los e seguir.

Entendi que estes espaços merecem o cuidado a partir da lentidão. "[...] espaço esconde, em seus cantos escuros e margens esquecidas, todos os objetos de medo e fobia que retornaram com tanta insistência para assombrar a imaginação daqueles que tentaram colocar o espaço para proteger sua saúde e felicidade" 25 . Debord definia a deriva como uma prática de passagem rápida por ambientes variados e, mesmo que possa ser em determinados momentos, a lentidão é parte intrínseca de sua efetuação.

O cuidado com estes espaços era atravessado por esta noção.

\footnotetext{
${ }^{25}$ Cf. VIDLER, 1992, p. 167.
} 
Cada vez mais o entorno escurecia e o desejo de jogar com sobrevivências aumentava. Cadê a ferrovia? Tonteira.

Tive sede. Leandro, que estava comigo, me deu água.

Uns passos adiante, um brilho na terra seca, sedimentada. Porque brilharia?

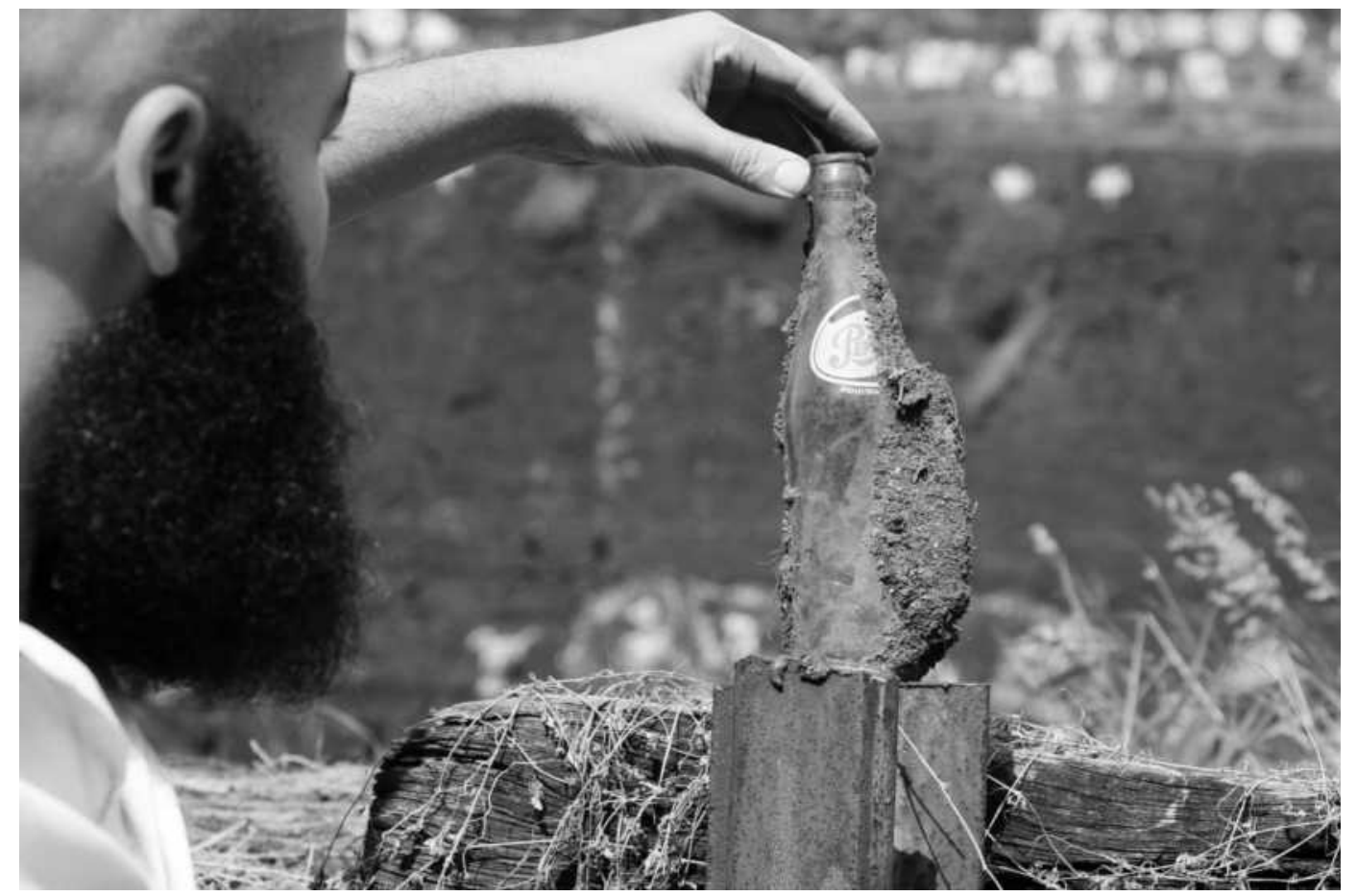

Figura 27. Garrafa de Pepsi, Engenho Novo, Rio de Janeiro.

Vagalumes mostrando-se a mim.

Quantas histórias cabem nestes muros?

Esta garrafa mostrou-me que para saber melhor é preciso pisar no chão de terra, sentir a terra, quase virar terra. "[...] é impossível evitar o pensamento lamacento quando se trata de projetos de terra [...] A mente e a terra encontram-se em um processo constante de erosão: rios mentais derrubam encostas abstratas, ondas cerebrais desgastam rochedos do pensamento, ideias se decompõem em pedras de desconhecimento, e cristalizações conceituais desmoronam em resíduos arenosos de razão" 26 .

Aqui, me pareceu impossível evitar o pensamento fragmentado ao encontrar a garrafa de Pepsi. Jacques diz que o fragmento arrasta o paradoxo de ser um sistema autônomo, mas não totalmente fechado em si, o que o cerca é transponível, inacabado.

Me peguei achando e juntando inacabados e reencontrando memórias.

\footnotetext{
${ }^{26}$ Cf. SMITHSON, 2006, p. 182.
} 
Da terra seca ao ar.

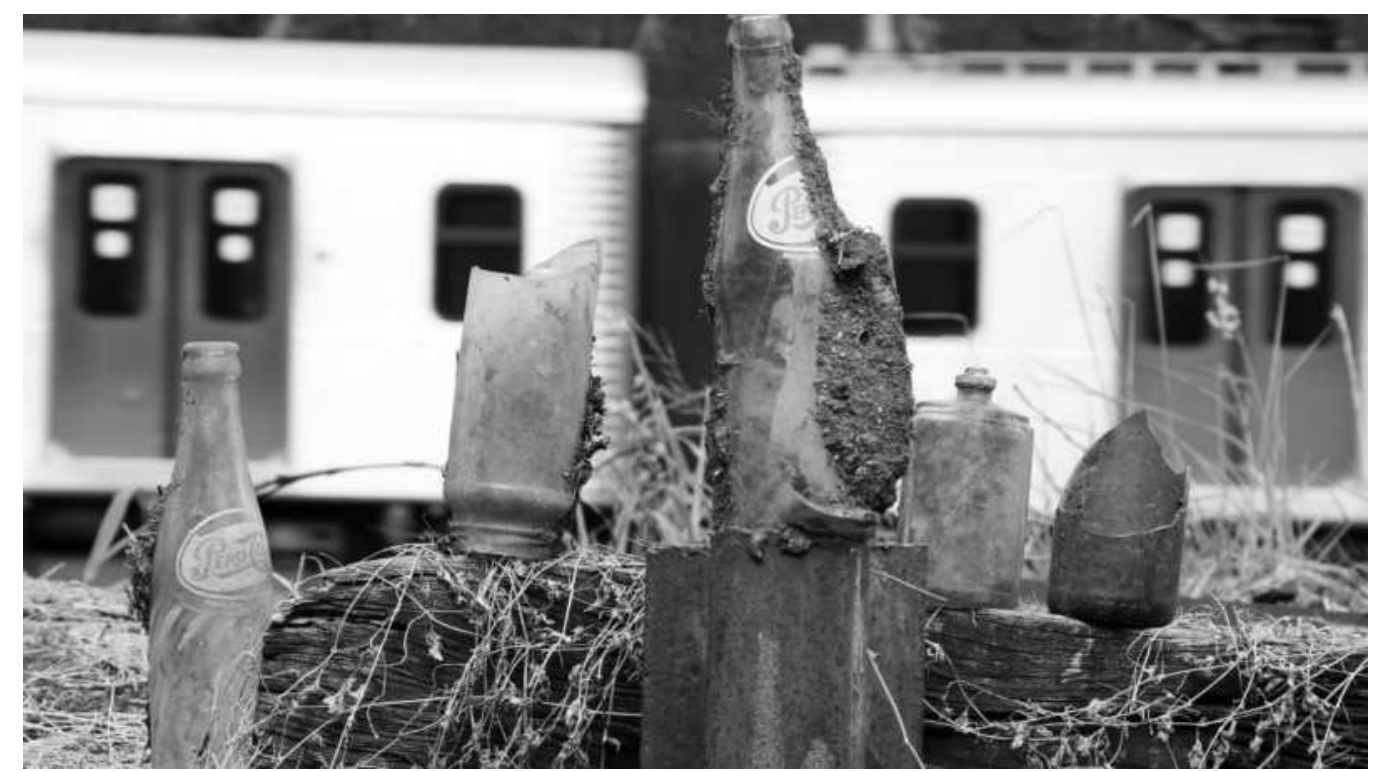

Figura 28. Copos e garrafas de vidro, Engenho Novo, Rio de Janeiro.

O vento os derrubaria logo depois, e isto me faria bem. Mais restos sobreviventes de muro a serem vividos. No entanto, pensei em como os restos escondidos nestes locais discursam sobre formas de sobrevivência a situações de enclausuramento geradas por estes muros. Duas delas: (1) Saber misturar-se a terra, encontrar movimento na sedimentação, mover os estratos, produzir devires tirando partido do esquecimento, do abandono e da inutilidade. (2) Saber misturar-se ao vento, abrir-se para os encontros inesperados, para os devires do território, e encontrar, nos esbarrões do percurso, outras memórias.

Suor. Leveza. Continuar. 


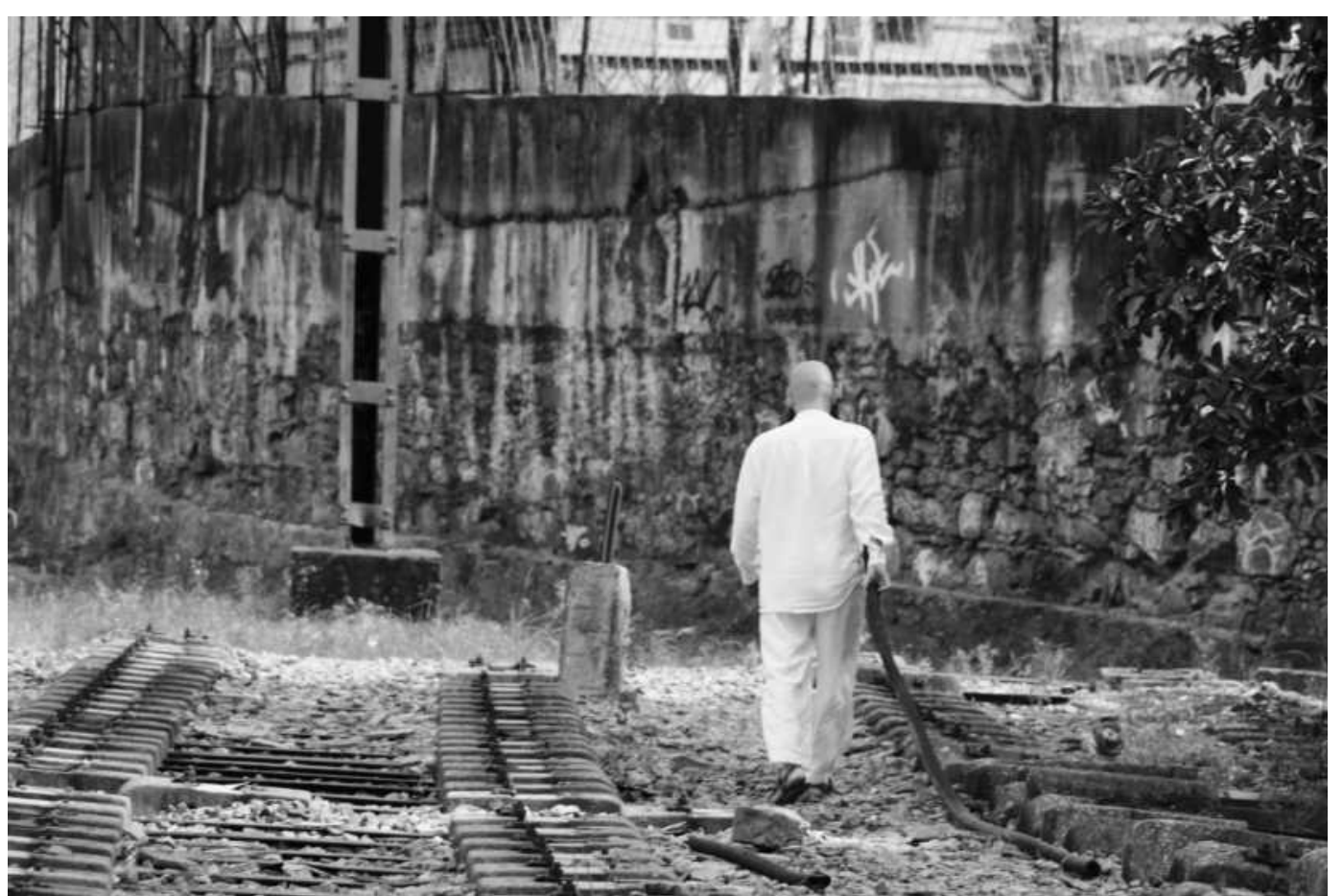

Figura 29. Cabo de borracha, Engenho Novo, Rio de Janeiro.

Linha férrea e outra linha:

Borracha no meio do chão de pedra.

Conforto guardado pelo muro do ramal Santa Cruz. Com o corpo bambo, fragmentando-se com o afeto pelos restos encontrados, senti que ele me traria outros encontros.

Aproximei-me do muro. Meus olhos e a mão que estava solta buscava o conforto da borracha nas pedras que construíam o muro. Dois trens passavam, simultaneamente, atrás de mim, lembrando do risco em que eu estava imerso naquele lugar. Fato que, novamente, alimentou o desejo de estar ali.

Quero o risco.

Deitar no risco.

Encontrei o nicho emborrachado dos muros e o fiz encontrar com a linha de borracha. Emborrachar.

Encontro perfeito.

É possível encontrar o conforto do macio na pedra? E a dureza da pedra na borracha?

O chamado foi feito.

Deitar para testar. 


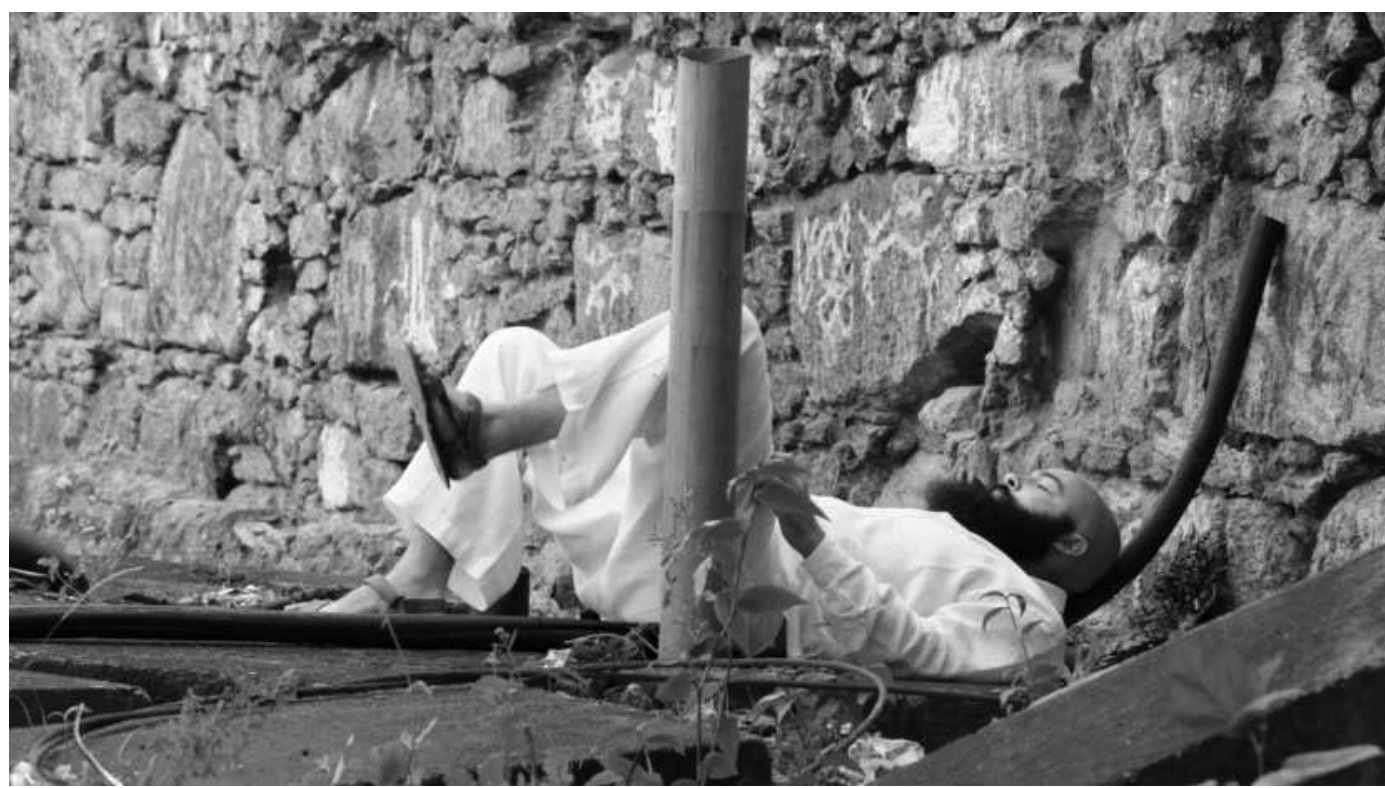

Figura 30. Produzindo vibrações, Engenho Novo, Rio de Janeiro.

Testar com as costas e cabeça. Jogo de equilíbrio. Produzir o encontro. Fechar os olhos.

Deitar-se no elemento emborrachado como forma de sentir as pulsações da terra e dos muros. Meus pés precisavam de ar, minhas costas e cabeça precisavam de terra. Sem sentir, a borracha foi uma mediadora, um dispositivo dentro do dispositivo muro, que me fez sentir suas vibrações. Alguns trens passaram e pude sentir suas reverberações energéticas desde o início da coluna ao topo da cabeça. Abri os olhos por um momento e tive noção da concretude que estes muros carregam. Fechei os olhos novamente.

As ondas energéticas que vêm do movimento dos trens são absorvidas por esta matéria. "É assim que para a ciência nômade, a matéria nunca é uma matéria preparada, portanto homogeneizada, mas é essencialmente portadora de singularidades (que constituem uma forma de conteúdo)". ${ }^{27}$

Me dei conta de que estes muros guardam em sua constituição toda esta força e estes fluxos que passam diariamente neste ramal ferroviário; alimentam-se disto, não à toa continuam erguidos. Uma estratificação energética do dispositivo.

Por outro lado, esta mesma energia se materializa nos restos ali encontrados, fornecendo-lhes potência disruptiva, uma vez que podem expor as condições restantes, as condições de inutilidade, de abandono deste muro, enquanto dispositivo urbano.

\footnotetext{
${ }^{27}$ Cf. DELEUZE; GUATTARI, 2017, p. 37.
} 
Abrir os olhos novamente. Levantar.

Ao caminhar pela borda da ferrovia, me dei conta de que tinha ficado bastante tempo deitado. O corpo precisava deste momento de experimentação sem os pés. Com os olhos aferidos para as pequenas luzes destes locais, encontro um elemento que me levou para outros lugares e pessoas.

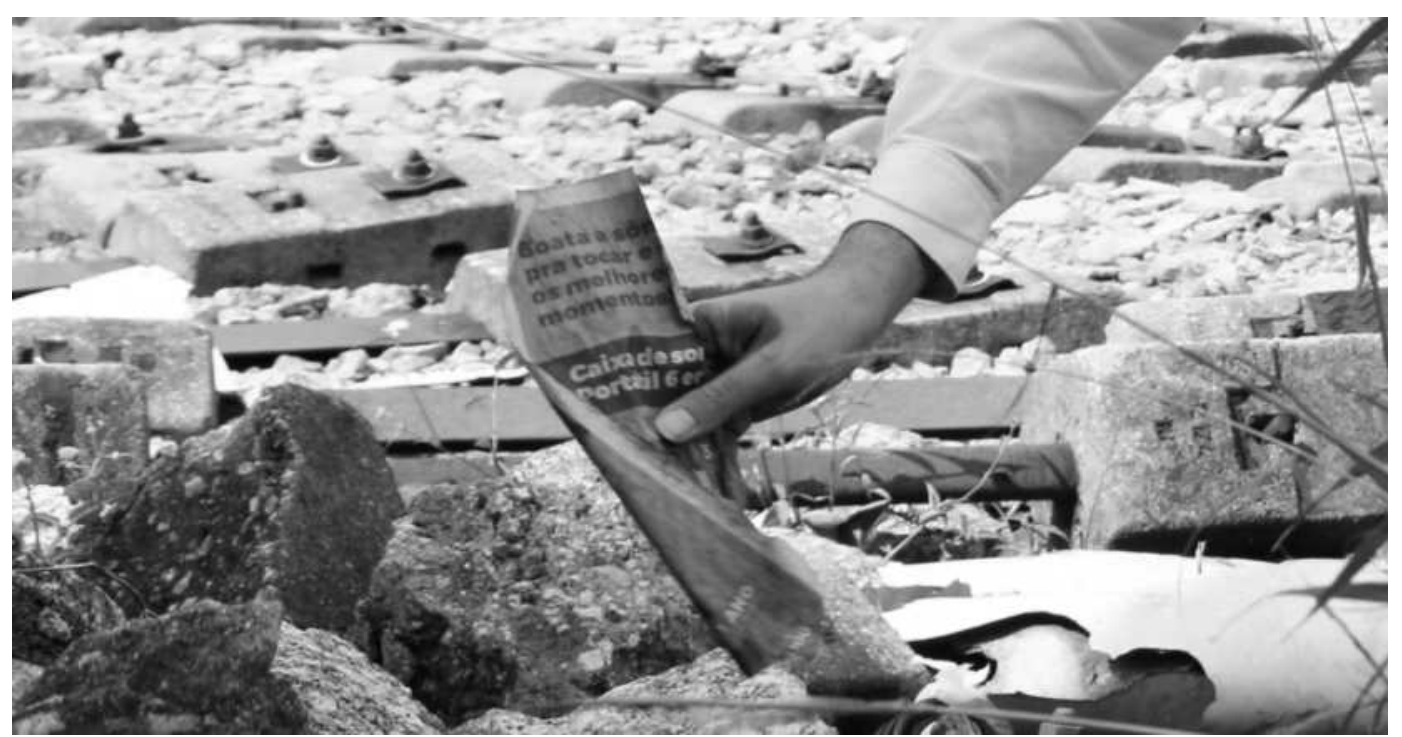

Figura 31. Jornal, Engenho Novo, Rio de Janeiro.

Rasgar a possibilidade de comunicação. Parece-me ser também uma forma de decretar a morte do pensamento. Jornal popular, rasgado.

Pensei, inevitavelmente, que estava vendo os muros de frente: resto de comunicação popular cortada, em frangalhos.

Estes muros poderiam querer voltar à sua impenetrabilidade, inviolabilidade, mas os restos, enquanto sobrevivências, não permitiam.

Deixei o resto de jornal fluir, libertei-o ao vento.

Alguns passos adiante e lembrei-me do arranhão que o arame me fez. 


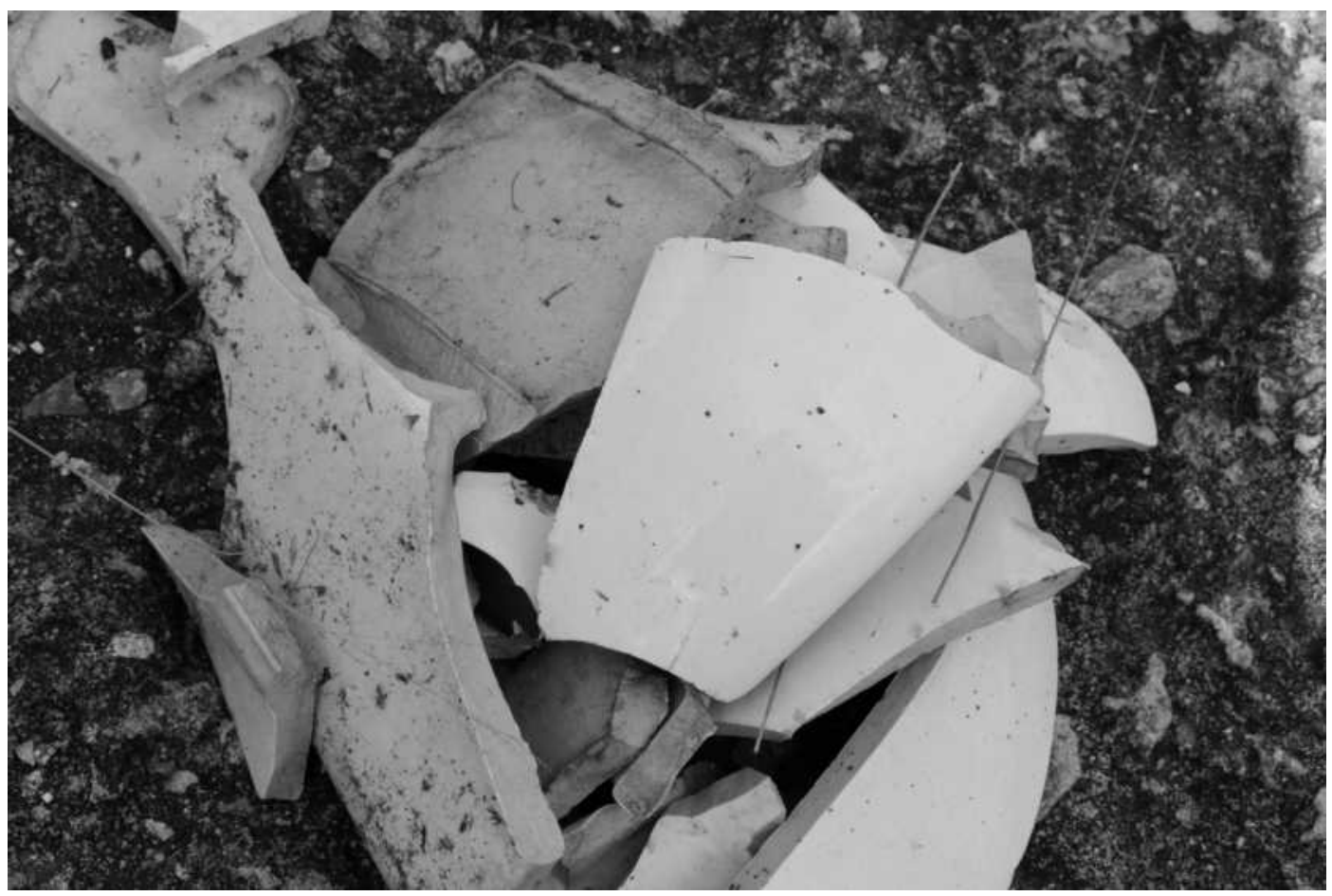

Figura 32. Cacos de louça, Engenho Novo, Rio de Janeiro.

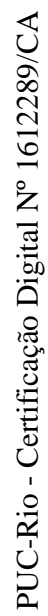

Os cacos não paravam de aparecer. Ao olhar em volta localizei vários fragmentos.

Separados. Não hesitei em juntá-los. O jogo. Jogar. Cortar. Os cortes me disseram algo sobre a intensidade da força que os fez estar daquele jeito.

Foram aniquilados.

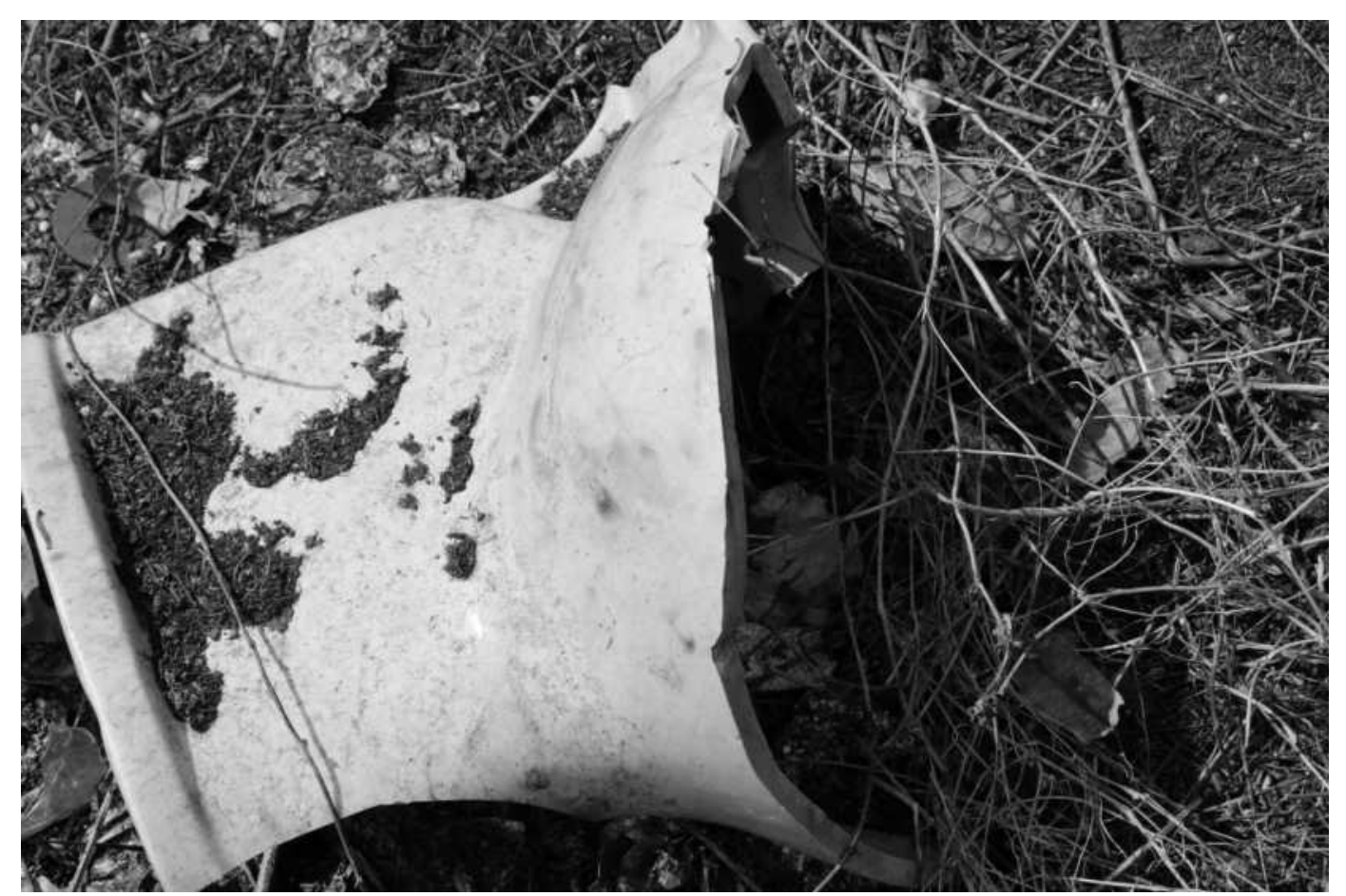

Figura 33. Vaso de louça, Engenho Novo, Rio de Janeiro. 
Logo entendi: quebrar para inutilizar. E minhas mãos sentiam a liberdade do arremesso para quebrar o vaso e com ele a liberdade do inútil. Jacques fala sobre a potência presente nas errâncias urbanas exatamente por produzirem táticas desviacionistas. Achar um vaso, achar os muros. Quebrar um vaso, quebrar os muros. Soou no meu pensamento como uma força guardada por dentro dos galhos secos que invadiam a peça aniquilada. E tudo isto na superfície das coisas.

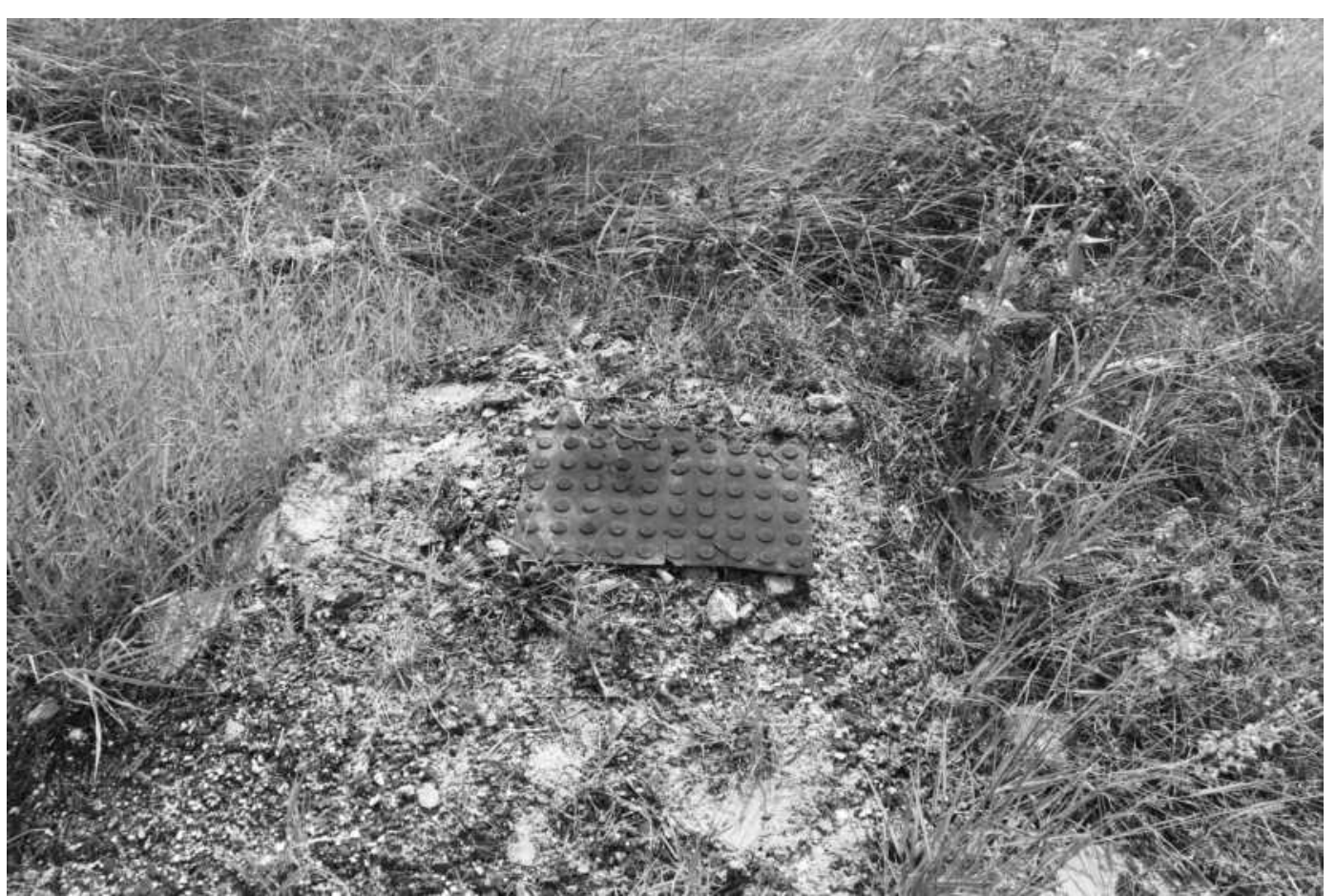

Figura 34. Piso antiderrapante, Engenho Novo, Rio de Janeiro.

Encontrar dinâmicas da ordem e do progresso sendo engolidas pela terra seca desta superfície expõe a potência disruptiva que o tempo tem sobre as lógicas de proteção e controle urbano. Amassar. Cobrir.

Um piso de borracha é engolido pelo tempo, pela terra. Sua retidão não cabe aqui, é desmontada pela abertura e liberdade da superfície natural.

Inteiramente à disposição desta superfície, o sol volta a aparecer, mas antes de lançar seus raios mais potentes ao meu corpo, meu olhar, aferido à escuridão, encontra sua última sobrevivência. 


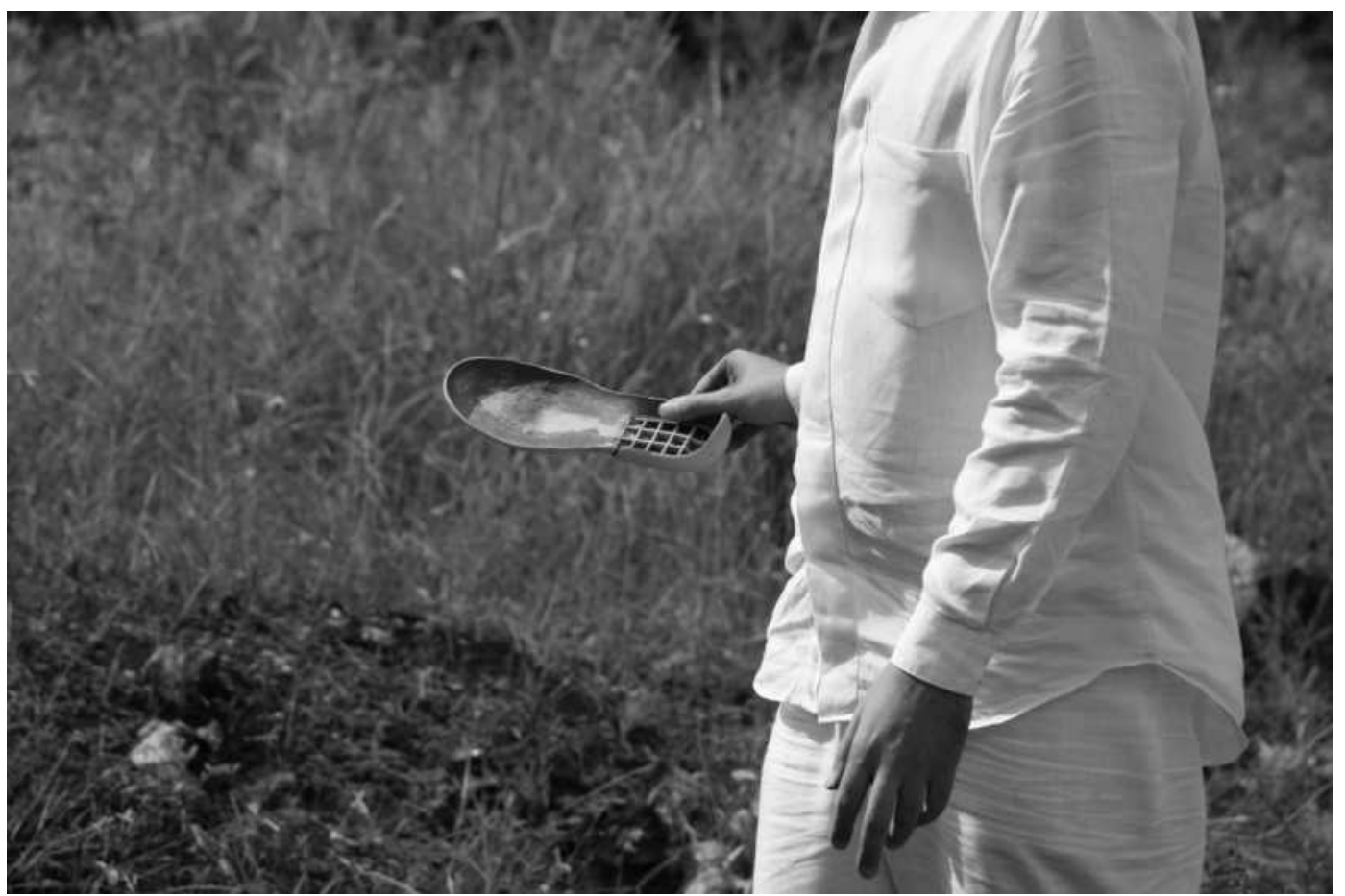

Figura 35. Palmilha, Engenho Novo, Rio de Janeiro.

Pés soados da deriva e uma palmilha.

As minhas sandálias, permitiam leveza, flexibilidade e resistência. A palmilha me fez ir além: permite leveza, flexibilidade e liberdade.

Resistência sem liberdade não faz sentido para o caminhar.

Neste momento, os muros poderiam ser tudo, menos resistência.

Refleti sobre a potência que uma palmilha abandonada, quando encontrada, tem como ferramenta de crítica. Quantas palmilhas poderiam ser ali encontradas? Os muros também são estes restos e seus devires acontecem nestes encontros inesperados.

Sentindo o movimento das superfícies da pele, percebi que o vento soava mais forte que antes: tire uma sandália e coloque o pé nela.

Assim o fiz. 


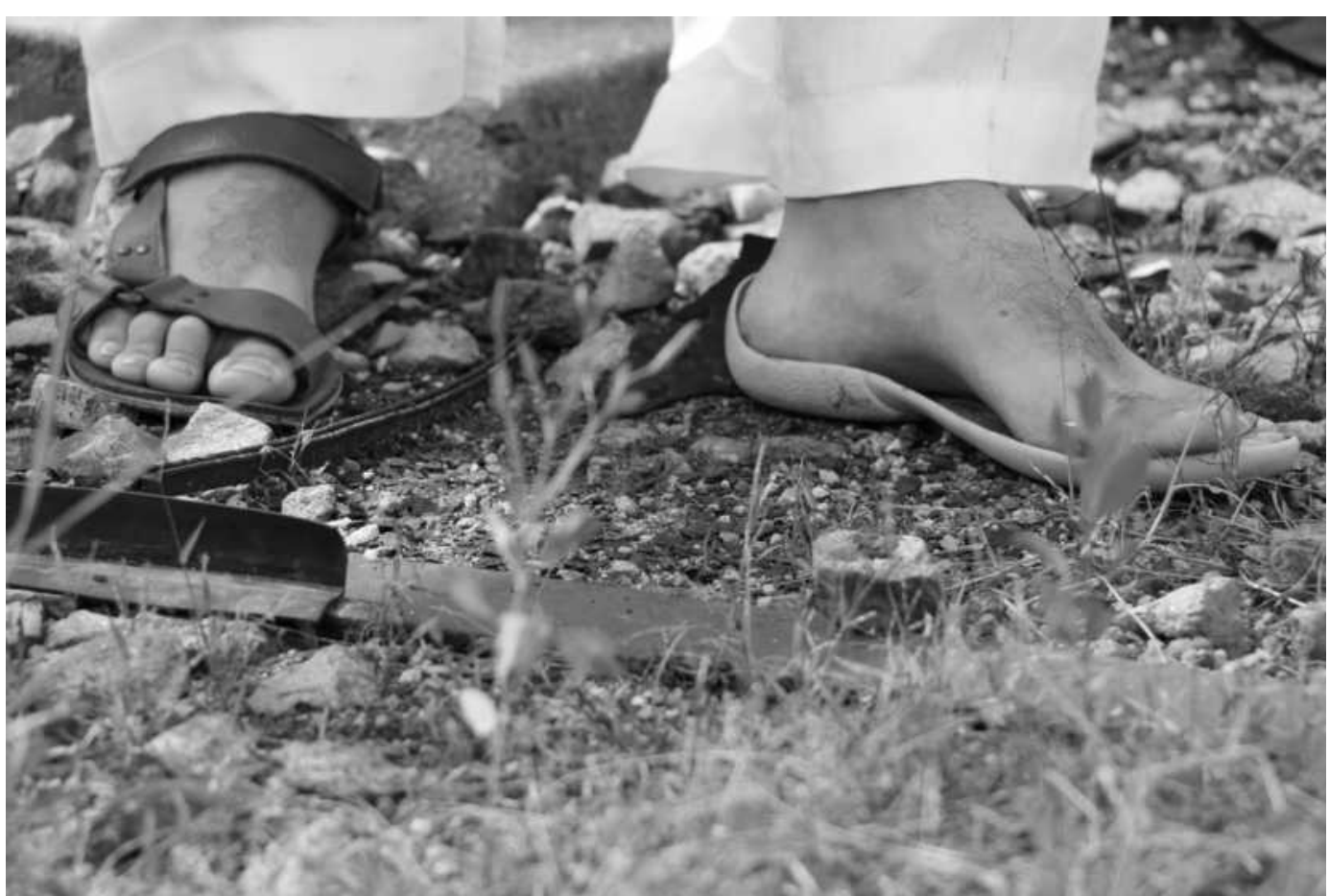

Figura 36. Descobrindo os pés, Engenho Novo, Rio de Janeiro.

Um ritual de passagem para a liberdade se iniciava.

Não segurei um minuto e retirei a outra sandália, colocando os pés no chão.

Como não fiz isto antes? Era outro lugar.

Despir-se das proteções do corpo, a meu ver, é parte do programa da deriva. Colocar-se à disposição do vento, seguir os devires de forma que os afetos se deem, desdobrem-se, produzam-se.

O caminhar instaurado foi absolutamente outro.

Sem bamboleios, incorporei os restos na estrutura do corpo e segui pelas bordas da ferrovia, enxergando os muros de longe. Seus restos não me deixaram enxergalo da mesma forma, com a mesma imponência ou impenetrabilidade antes sedimentada.

Como novas luminosidades nestes espaços escuros, elas engendram, como coloca Ribeiro, uma luta surda por virar acontecimento, que cada vez mais está articulada com uma luta por sobrevivência ${ }^{28}$.

Me pergunto, junto com Ribeiro, porque desconhecer esta luta surda e a força do acontecimento?

Descalço e leve, continuei a seguir pelas bordas da ferrovia e avistei de longe a materialização desta pergunta em cinco palavras:

\footnotetext{
${ }^{28}$ Cf. RIBEIRO, 2010, p. 39.
} 
Bermuda,

Chinelo,

Boné,

Bigode,

Vassouras.

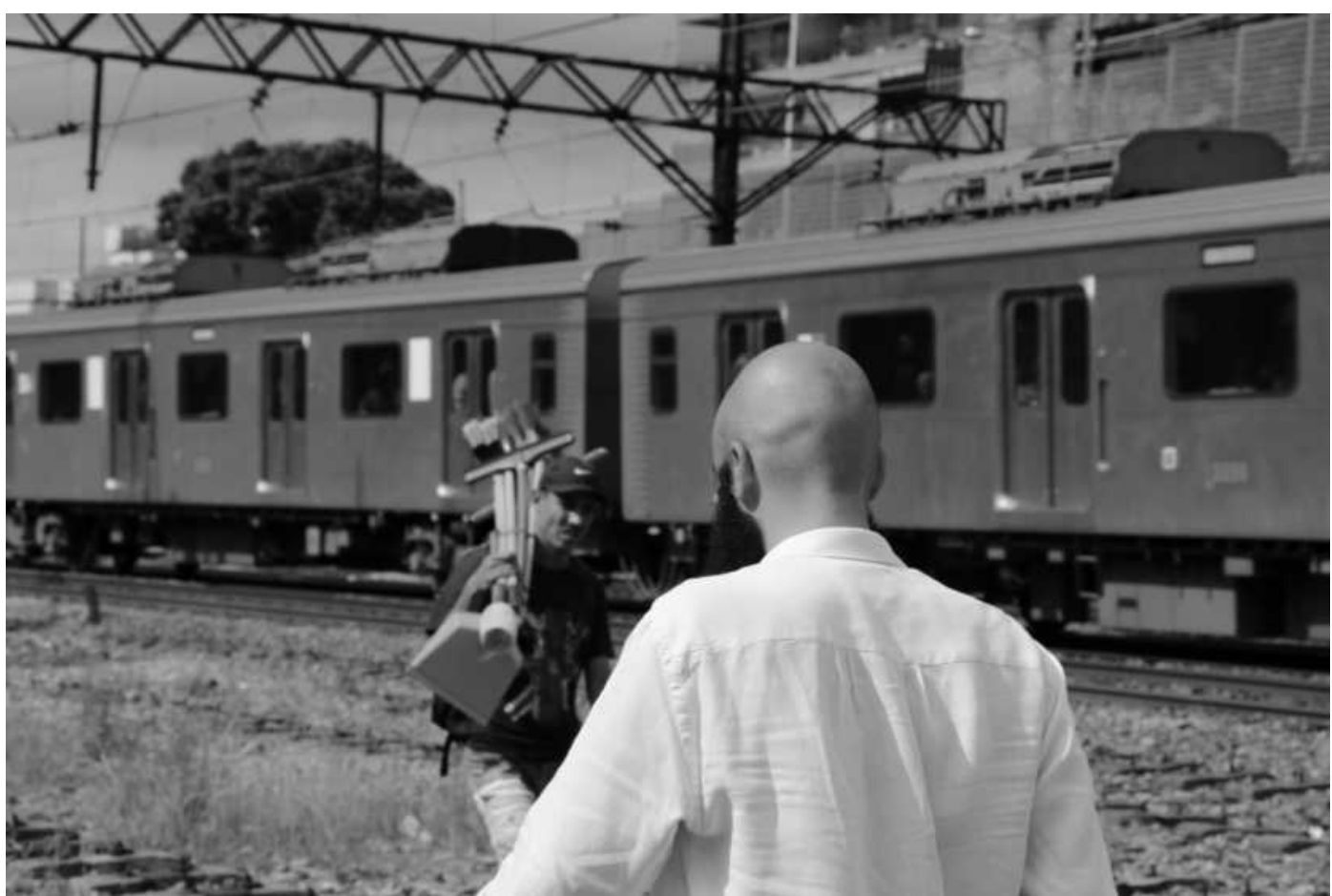

Figura 37. Homem carregando vassouras, Engenho Novo, Rio de Janeiro.

O vento, meu mensageiro fiel, soprou e eu ouvi: Sorrir e continuar e continuar e continuar. 


\section{Furos}

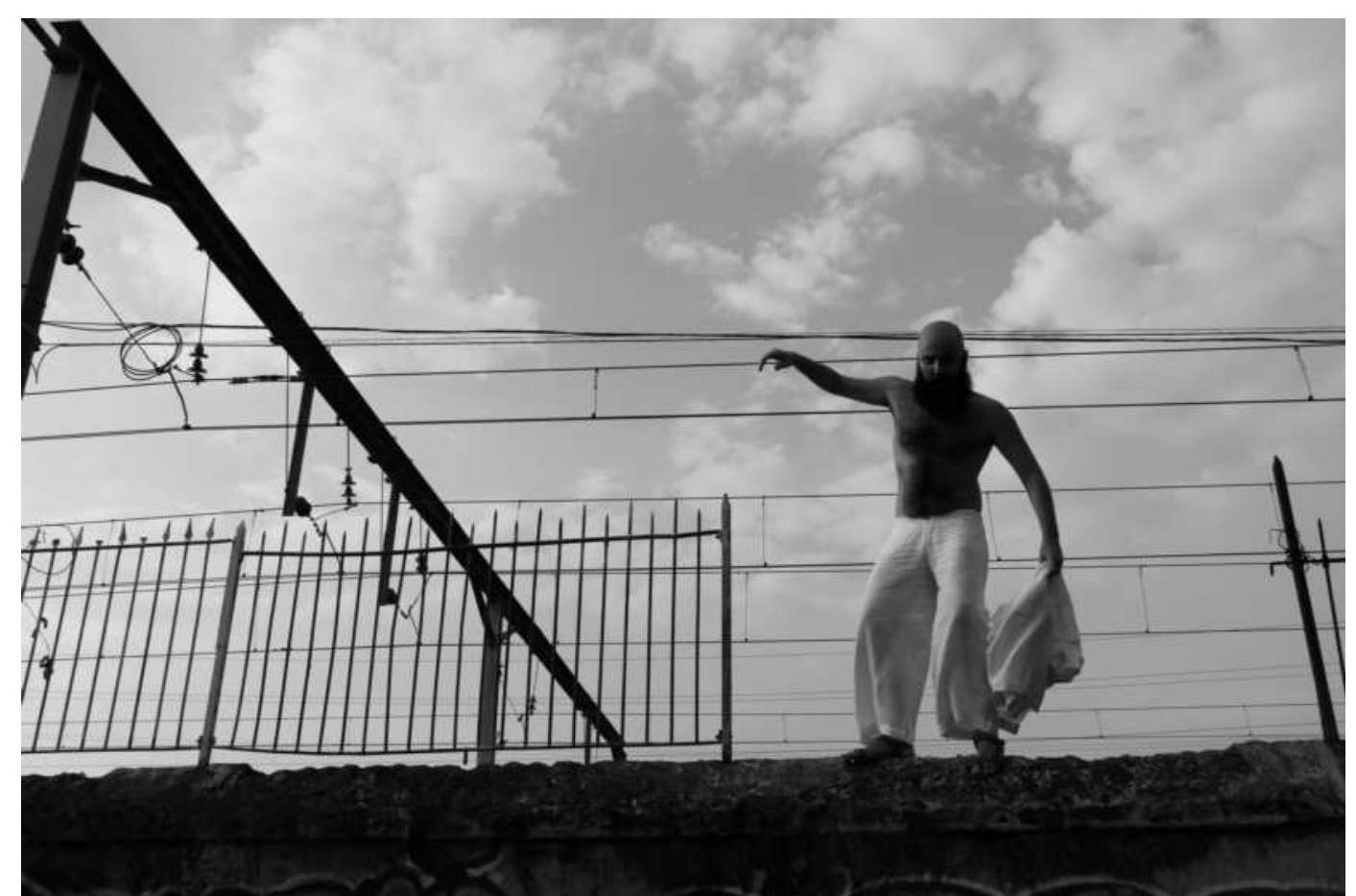

Figura 38. Transurbância através dos muros do ramal ferroviário Santa Cruz, Encantado, Rio de Janeiro.

A encruzilhada [...] é o lugar das incertezas, das veredas e do espanto de se perceber que viver pressupõe o risco das escolhas. Para onde caminhar? A encruzilhada desconforta; esse é o seu fascínio. O que dizemos dessa história toda é que em nossas vidas nós mesmos encantamos. Há que se praticar o rito; pedimos licença ao invisível e seguimos como herdeiros miúdos do espírito humano, fazendo do espanto o fio condutor da sorte. Nós que somos das encruzilhadas desconfiamos é daqueles do caminho reto. (SIMAS; RUFINO, 2018, p. 24)

\subsection{Imerso em encruzilhadas}

Ao olhar para os muros do ramal ferroviário Santa Cruz, especialmente do Morro da Mangueira em direção à zona oeste, é possível identificar uma série de furos em sua estrutura física. 


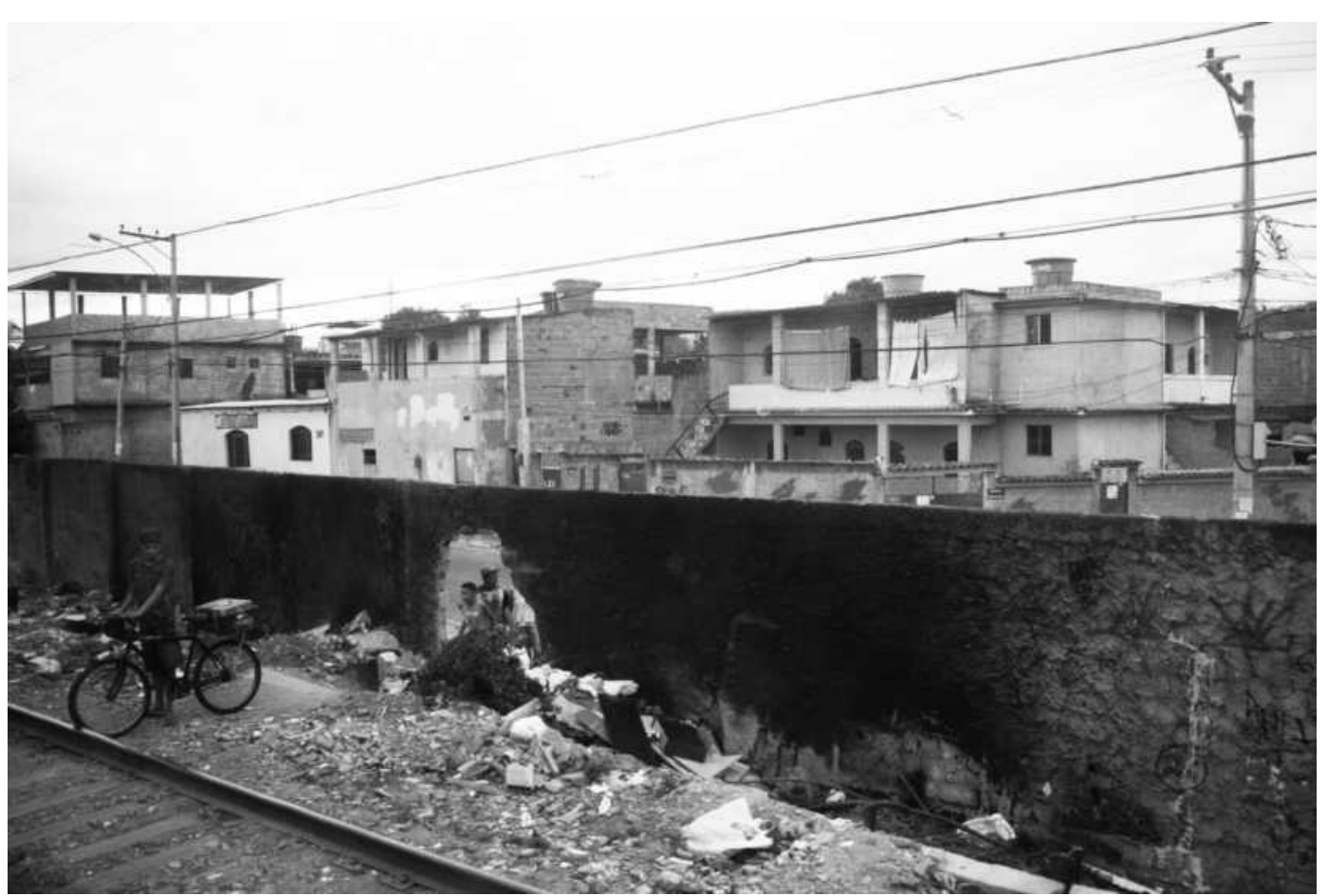

Figura 39. Furo de passagem em Magalhães Bastos, Rio de Janeiro.

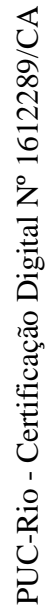

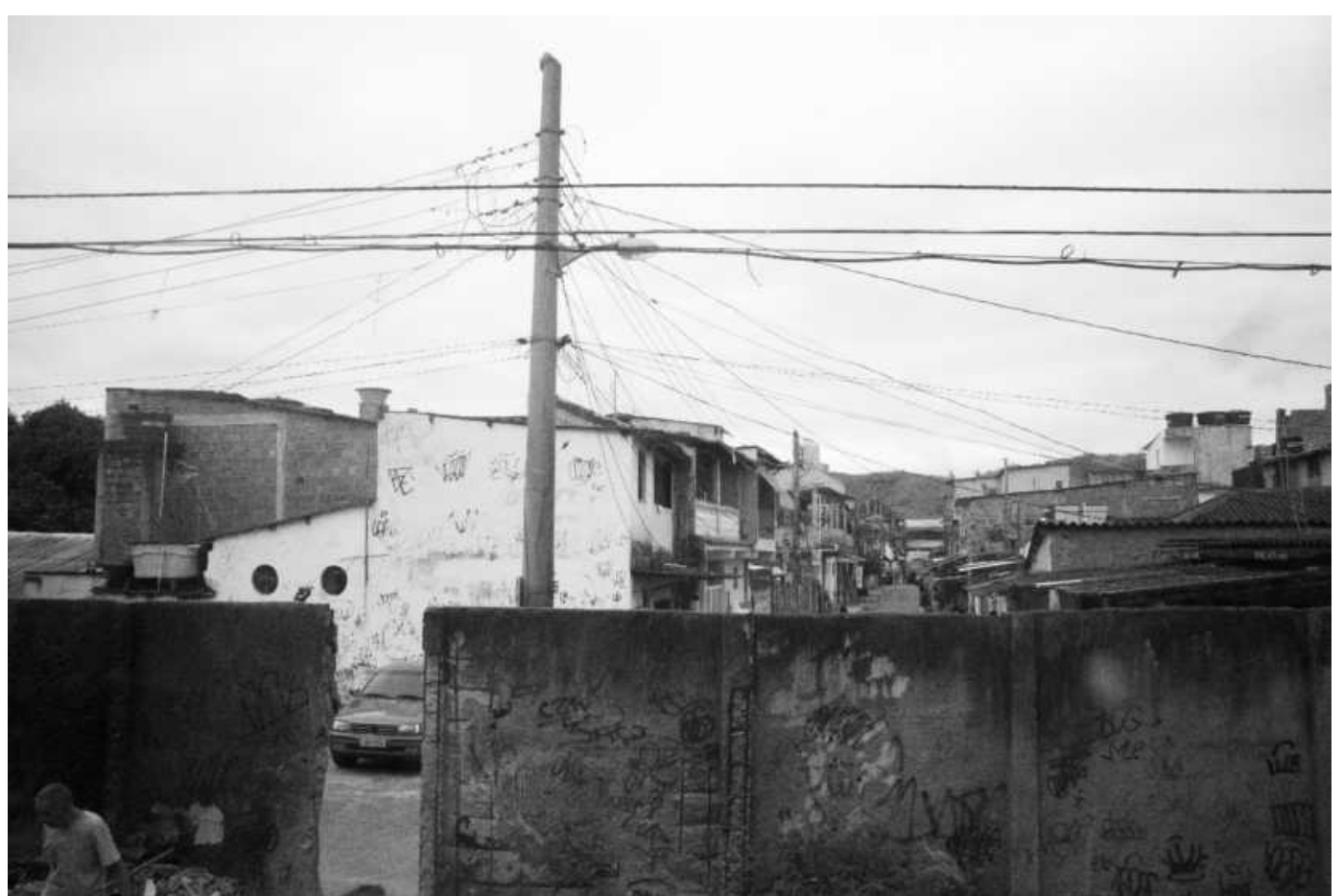

Figura 41. Furo em Bangu, Rio de Janeiro. 


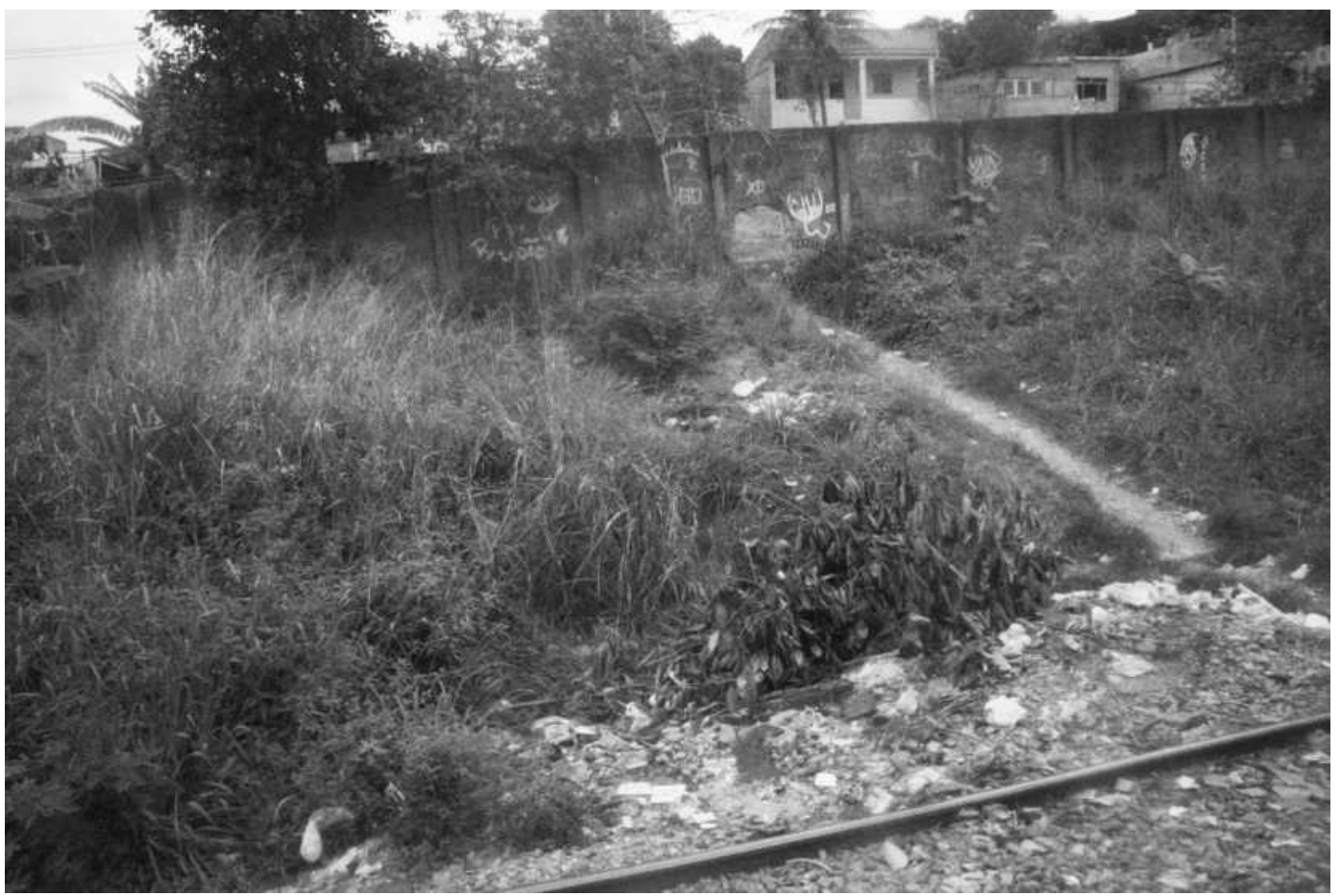

Figura 40. Furo em Campo Grande, Rio de Janeiro.

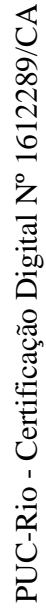

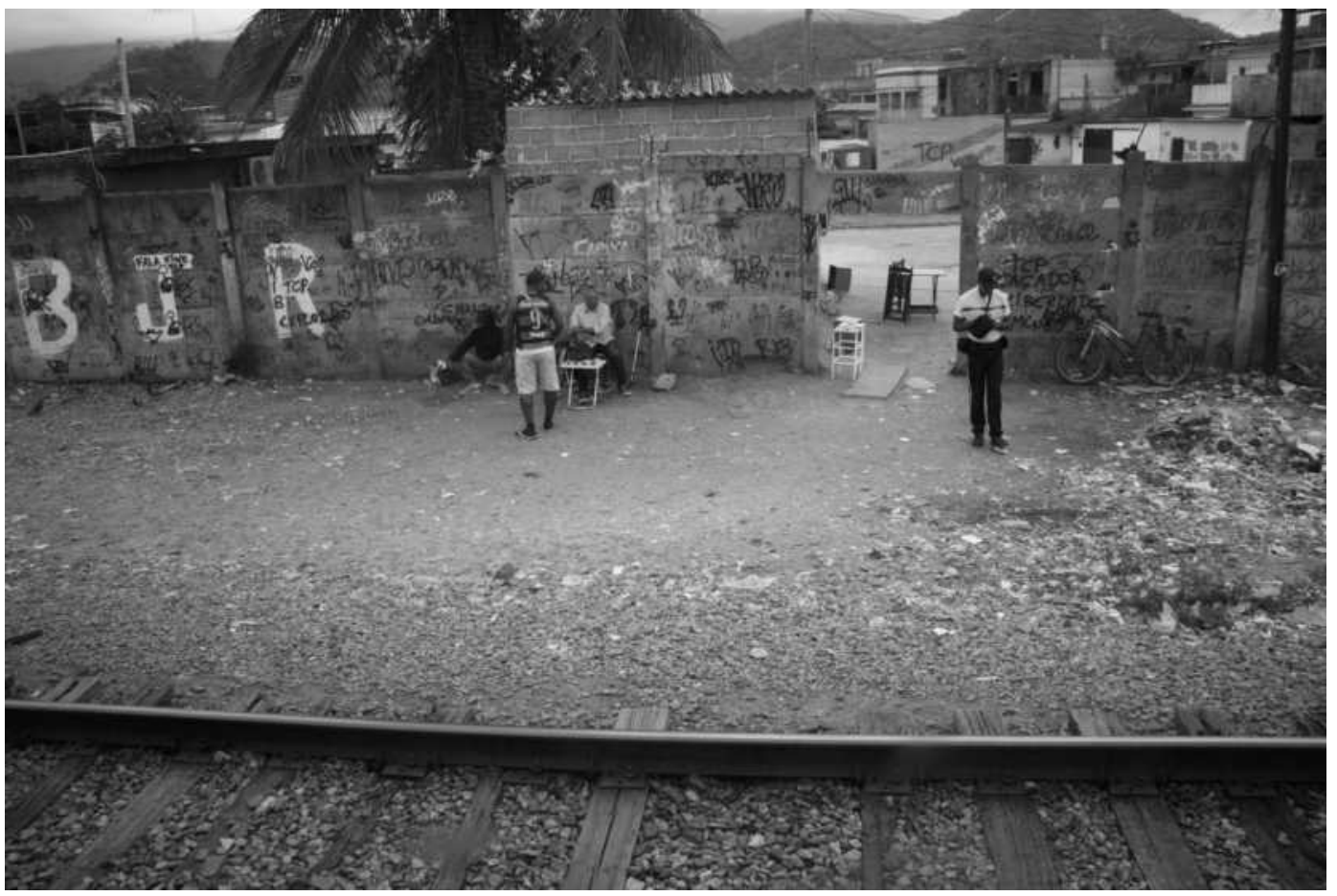

Figura 41. Furo em Santíssimo, Rio de Janeiro. 


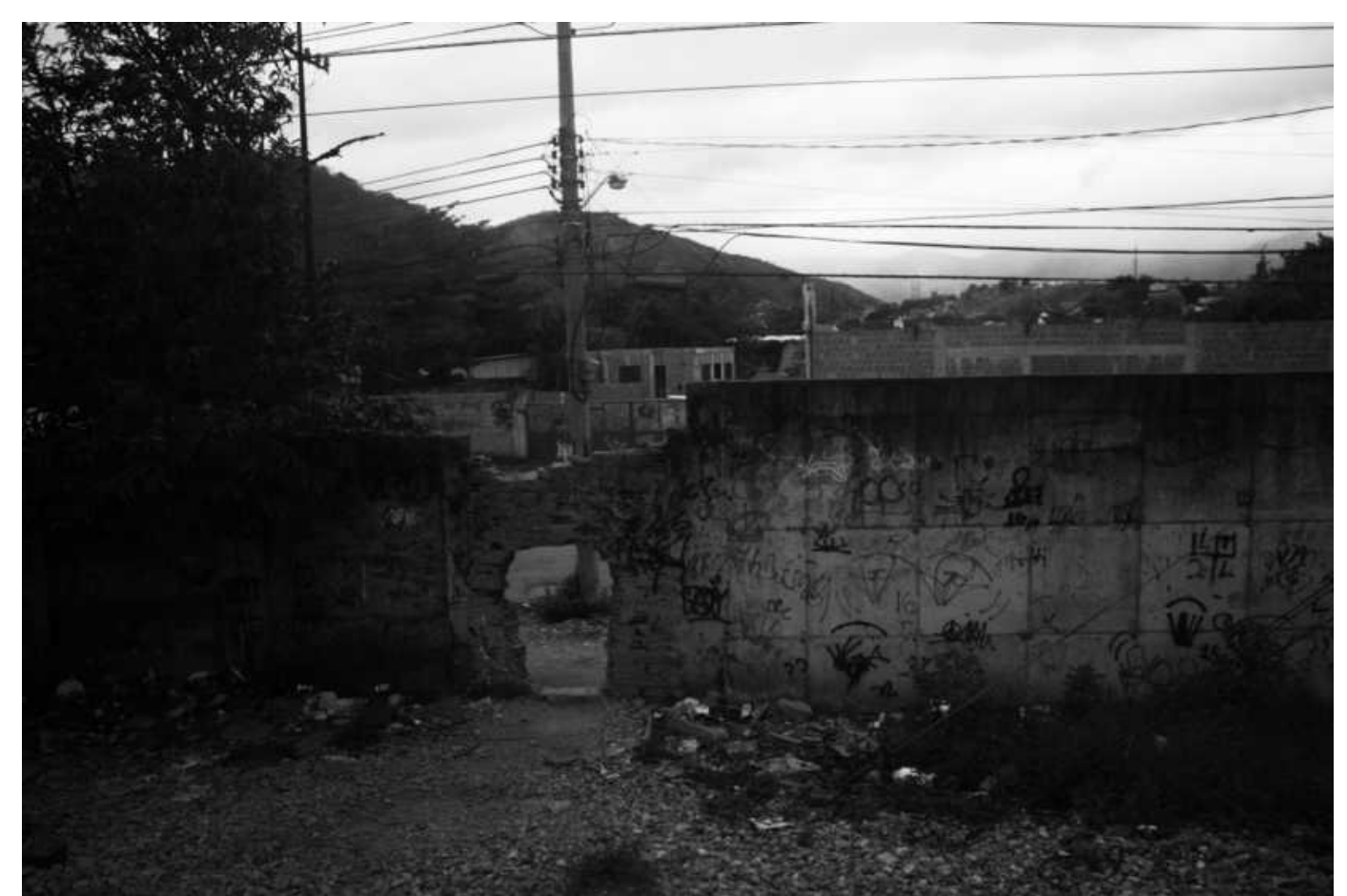

Figura 42. Furo em Senador Camará, Rio de Janeiro.

Estas imagens apresentam uma lógica de ruptura que se repete com maior intensidade na medida em que o ramal se desenvolve para dentro do subúrbio e zona oeste do Rio de Janeiro, sendo a maior parte dos furos efetuados por uma questão funcional de atravessamento. Estes rompimentos colocam em discussão o entrelaçamento do liso e do estriado deleuze/guattariano, especialmente no que se refere à questão colocada pelos autores, da "superfície" ou do "espaço". No espaço estriado, "fecha-se uma superfície a ser repartida segundo intervalos determinados, conforme cortes assinalados; no liso, 'distribui-se' num espaço aberto, conforme frequências e ao longo dos percursos" (DELEUZE; GUATTARI, 2017, p. 200, grifo dos autores).

Tais furos, parecem estar entre o liso e o estriado, pois ao mesmo tempo que se configuram como passagens, atravessamentos funcionais, parecem acontecer de maneira não prevista, sem medida, por uma liberdade dos fluxos, dos percursos.

No ramal ferroviário Santa Cruz, o interesse nas estações de parada como pontos de atravessamento se intensificou diante dos últimos grandes eventos que a cidade abrigou, a Copa do Mundo em 2014 e o Jogos Olímpicos em 2016, fato que possibilitou a modernização de muitas estações, principalmente ao longo deste ramal ferroviário, como: São Cristóvão, Maracanã, Engenho de Dentro e Deodoro. Já as zonas entre estações, onde os muros em questão acontecem, 
continuaram mantendo suas características, sobretudo, a de invisibilidade. Sendo assim, a produção destas rupturas possui, comumente, certa vinculação às ideias de ilegalidade, de medo, de insegurança e de arranjo precário, especialmente, porque se encontram, na maioria dos casos, em zonas de instabilidade social.

Tal fato fortalece a ideia de que estes furos, mesmo tendo função de atravessamento de pessoas - fato que os conecta com o espaço estriado - têm em sua construção alisamentos, isto é, são efetuados com algum nível de subordinação aos percursos espontâneos realizados fora dele. No entanto, esta identificação de um imbricamento mais claro entre o liso e o estriado não se afasta de uma aproximação com o que Deleuze e Guattari colocam como parte de um processo de estratificação:

Os estratos têm uma grande mobilidade. Um estrato é sempre capaz de servir de substrato a outro, ou de percutir um outro, independentemente de uma ordem evolutiva. Sobretudo entre dois estratos ou duas divisões de estratos produzem-se fenômenos de interestratos: transcodificações e passagens de meio, misturas. Os ritmos remetem a esses movimentos interestáticos, que são, igualmente, atos de estratificação (DELEUZE; GUATTARI, 2017, p. 230).

Os furos lá existentes funcionam como passagens de meio, como ligações interestáticas, na medida em que mantêm suas características de funcionalidade, em sua maioria. No entanto, tal movimento de ruptura destes limites desperta especial curiosidade, pois configura-se, em si, como uma ação urbana de risco, que flagra um desejo de maior liberdade de fluxos na cidade. Denotam certa expectativa de outros caminhos para além destes muros, fato que se alinha com o que Solà-Morales discute em terrain vague sobre as reverberações nas subjetividades urbanas:

Estrangeiros a nossa própria pátria, estranhos em nossa cidade, o habitante da metrópole sente os espaços não dominados pela arquitetura como reflexo de sua própria inseguridade [...] que, em sua posição externa ao sistema urbano, de poder, de atividade, constituem uma expressão física de seu temor e inseguridade, mas também uma expectativa do outro, do alternativo, do utópico, do porvir (SOLÀ-MORALES, 2002, p. 188).

Ao considerar isto, penso que é possível reconhecer a potência que estes atravessamentos têm, em si, pois são movimentos de ruptura com o limite dado pelos muros. No entanto, pergunto-me a respeito de certa tendência ao estriamento de tais furos, de um tênue congelamento de sua potência crítica quando se "rendem" apenas à função do atravessar. Tal fato me leva a questionar 
sua real potência enquanto prática de atualização nos dispositivos, pois tende a priorizar os pontos de chegada e partida em detrimento da abertura às múltiplas possibilidades dos percursos (como faria em um espaço liso). Assim, delineio uma questão importante: Como pensar um outro "furar" no dispositivo muro do ramal ferroviário Santa Cruz?

Penso que existe a possibilidade de pensar este outro "furar" através da noção de encruzilhada.

Luis Antônio Simas e Luiz Rufino constroem um conceito de encruzilhada como uma alternativa às abordagens que, segundo os autores, partem de visões de mundo que empobrecem complexidades urbanas (SIMAS; RUFINO, 2018, p. 11). Tal conceito está intrinsecamente relacionado com o fenômeno que os autores nomeiam de culturas de síncope (SIMAS; RUFINO, 2018, p. 18): são aquelas que sobrevivem, historicamente, nas frestas e vielas da cidade, nos vazios entre os espaços de poder hegemônico. A síncope "é uma alteração inesperada no ritmo [...] rompe com a constância, quebra a sequência previsível e proporciona uma sensação de vazio que logo é preenchida de forma inesperada" (SIMAS; RUFINO, 2018, p. 18).

Para os autores, alguns exemplos deste tipo de cultura são o samba, o candomblé, a umbanda, o jongo, a capoeira, os blocos de carnaval, que sobrevivem e reexistem no tempo, sobretudo por sua capacidade de negociar, de driblar as forças de poder que tentam, historicamente, extingui-los. Exatamente por construírem tal capacidade de negociação, conectam-se com este movimento de síncope, que não se pode prever ou precisar suas direções.

Assim, o conceito de encruzilhada se constitui como uma abordagem de apreensão e compreensão destas culturas de síncope abandonando perspectivas generalizantes e partindo para outras, como Simas e Rufino definem:

A encruzilhada é o tempo e o espaço aonde se desferem os contragolpes do homem comum. Lá se joga o punhal de ponta para cima, para que o mesmo caia de ponta para baixo. Os giros, dribles, negaças e virações são mais que necessários. Desobediência e inconformismo são também fundamentais para a produção de uma certa "cisma epistêmica" que favoreça a tática de deseducação (SIMAS; RUFINO, 2018, p. 20, grifo meu).

É possível perceber dois aspectos importantes nesta abordagem da encruzilhada: (1) a operação por tática de deseducação, que, a meu ver, pode ser conectada com a noção de tática desviatória, pois, ambas buscam desmontar 
modos de pensamento e ação das forças hegemônicas; (2) a operação a partir da imersão nos movimentos, especialmente os imprevisíveis, acolhe os "giros", os “dribles", as "virações”, presentes nestas culturas de síncope, como potência para gerar outros modos de experimentar o espaço urbano.

Existe um terceiro aspecto fundamental para o entendimento desta abordagem: o de encantamento (SIMAS; RUFINO, 2018, p. 17). Tal aspecto é construído ao reconhecer a encruzilhada como um lugar em que rituais de oferta a deuses e a seres mitológicos foram e são feitos como forma de buscar outros caminhos através do contato com uma dimensão "mágica", energética e invisível da vida. Rituais de busca pela "sorte", pela "abertura aos bons caminhos". O encantamento torna-se, assim, uma ação que possibilita a transformação do sentido concreto das coisas, objetos e comidas que são oferecidas para um sentido outro: de energias, de fluxos e de forças que eles podem convocar.

Sendo assim, entendo a encruzilhada, no limite, como a possibilidade de encantar as síncopes na concretude da cidade através da magia de seus fluxos desconhecidos e imprevisíveis.

Transpondo estes conceitos para o dispositivo muro do ramal ferroviário Santa Cruz, penso que, primeiramente, o entendimento de síncope guarda potência para pensar, de uma outra forma, os vazios entre os "plenos" (CARERI, 2017, p. 18) deste muro: como possibilidades de drible, de desvio inesperado. Em seguida, penso que tais síncopes, associadas a uma abertura ao encantamento dos fluxos que as geram, podem, por fim, produzir encruzilhadas. Tais modos de operar abrem a possibilidade de retirar certa "obrigatoriedade" do atravessar e, assim, produzir atualizações por meio deste outro "furar" no dispositivo muro.

Ao considerar que esta ação acontecerá a partir dos espaços que margeiam o muro, destes estratos, há um atravessamento possível desta noção com a questão posta por Solà-Morales, quando se pergunta a respeito da possibilidade de uma postura crítica diante dos terrain vagues, apontando claramente um caminho de ação:

Sem dúvidas, através da atenção às continuidades. Mas não da continuidade da cidade planejada, eficaz e legitimada, mas todo o contrário, através de uma escuta atenta dos fluxos, das energias, dos ritmos que o passar do tempo e a perda dos limites tem estabelecido (SOLÀ-MORALES, 2002, p. 192, grifo meu). 
Penso que esta proposição de Solà-Morales de uma ação através das continuidades deixa clara a conexão com o modo de operar do conceito de encruzilhada: a abertura aos fluxos, às energias e, especialmente, aos ritmos, porém não os previamente estabelecidos como se produz em um regime de estriamento, mas, sobretudo, aqueles imprevisíveis, os de síncope, que são produzidos no inesperado dos caminhos. Desta forma, abre-se a possibilidade de discutir este conceito enquanto potencial produtor de alisamentos no dispositivo muro do ramal ferroviário Santa Cruz.

Diante destas considerações, entendo que para produzir encruzilhadas é preciso antes produzir as síncopes em que elas se dariam, os vazios entre "plenos" destes muros e abrir-se para a dimensão do encantamento.

Assim, discutirei a transurbância enquanto errância que possui um modo de operação que se aproxima dos conceitos de síncope e encruzilhada: permite o atravessamento de territórios, seguindo fluxos e energias, invadindo-os por meio de um reconhecimento, nos locais que percorre, de possibilidades de ruptura de limites através do movimento em si e da capacidade de parar e de construir alianças imprevisíveis com o meio.

\subsection{Do derivar entre o transurbar: encantando furos}

A deriva é uma errância que arrasta algumas características e questões colocadas pelas deambulações: (1) uma relação com os movimentos do inconsciente no corpo, atualizando-o para uma relação ativa com a cidade; (2) a atenção para os restos como sobrevivências, atualizando-a de seu aspecto colecionador para um lúdico-construtivo; (3) a busca por um estranhamento daquilo que é familiar, atualizando certo pessimismo para uma ideia de participação.

Tendo este "arrastamento" em vista, há aspectos da deriva que foram desdobrados por Careri, em seu livro Caminhar e Parar (2017), em que reúne diversos textos das errâncias que praticam, as transurbâncias.

O grupo Stalker, organizado pelo autor, iniciou suas errâncias na década de 1990, mais precisamente em outubro de 1995, sendo a primeira ação chamada de Stalker através dos territórios atuais, quando o grupo atravessou diversas zonas abandonadas do subúrbio de Roma. Careri, ao falar sobre estes percursos 
errantes, define: “a transurbância é - como tinha sido o percurso errático - uma espécie de pré-arquitetura da paisagem contemporânea” (CARERI, 2013, p. 31).

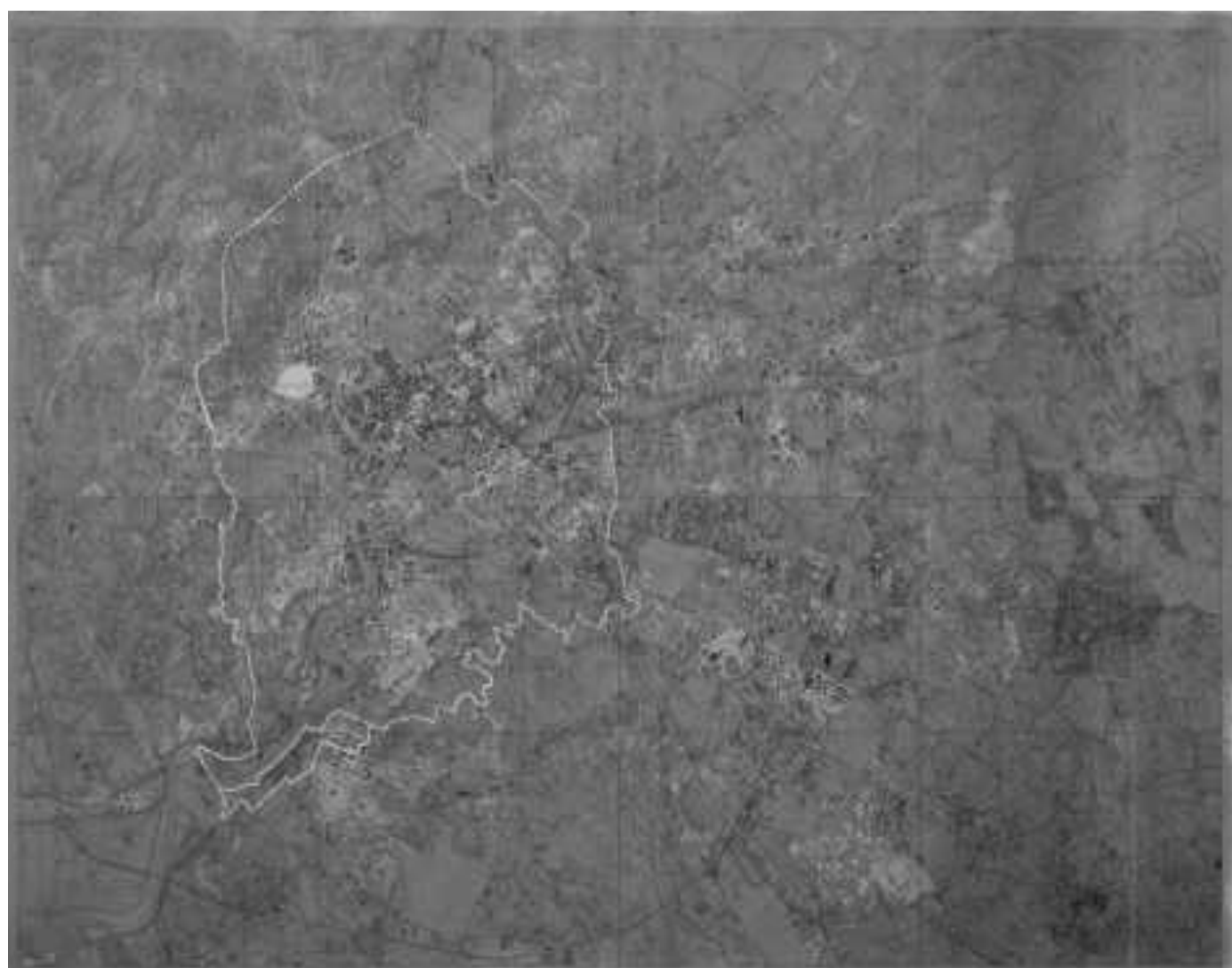

Figura 43. Mapa da ação "Stalkers através dos territórios atuais" realizada pelo grupo Stalker.

Ao colocar esta errância nestes termos, como uma espécie de leitura e escrita da paisagem, existe um primeiro ponto que assume protagonismo nas reflexões engendradas pelo autor: o vazio das cidades. Tal aproximação com este tema é feita inicialmente através do conceito de zona, em que se estabelece um diálogo com o filme Stalker (1980) de Andrei Tarkóvski, no sentido de dar certo delineamento teórico ao modo com que as relações estabelecidas com os vazios dos espaços percorridos se dava (CARERI, 2017, p. 13).

No filme em questão, a zona configura-se como uma espécie de território flutuante que, mesmo em face de uma suposta aterrisagem extraterrestre, que resulta em um rígido controle de suas bordas, encontra na zona interior lugares e caminhos expansivos de forma natural e não planejada. Neste espaço, a figura do Stalker, personagem que conduz as pessoas a esta zona, assume papeis importantes: (1) conhecer suas entradas, suas frestas de penetração, suas trilhas secretas; (2) conduzir a ruptura dos limites da zona; (3) experimentar esta paisagem em seu devir contínuo a partir da construção de táticas específicas, ou 
melhor, de rituais que permitem não somente atravessá-la, mas, sobretudo, estar aberto para receber suas mensagens e "ser digno daquilo que acontece" (CARERI, 2017, p. 14$)^{29}$ durante o caminho.

Desta forma, penso que o sentido de vazio para a transurbância assume um viés específico: é construído não como uma ausência, mas como uma presença de possibilidades, fluxos, forças e singularidades a serem vividas. É nele que se pode produzir a potência dos lugares.

Assim, diante da identificação destes papeis do Stalker, intrinsecamente vinculados ao sentido de vazio para esta errância, há dois aspectos que posso inferir: (1) o valor que se dá ao processo. Priorizar o que experiência tem de singular e múltiplo em termos sensoriais e perceptivos ao longo de sua construção, secundarizando o objetivo pelo qual os errantes resolveram realizar tal intento. Um abrir-se para os devires do espaço; (2) o valor dado ao desconhecido. Entrar na zona, invadir seus limites desconhecendo inteiramente o espaço. Um abrir-se para as possibilidades (infinitas) de experiência.

Partindo disto, penso que existe uma aproximação possível destes aspectos com a noção de encruzilhada, pois, ao considerá-la como um tempo e um espaço de movimento e de encantamento, é possível realizar uma articulação com a questão do processo e do desconhecido, respectivamente. Reconheço, sobretudo no filme de Tarkóvski, uma clara abertura para uma dimensão "mágica" da experiência: a crença na possível presença de extraterrestres, nos sons que surgem da natureza e transformam o percurso, nas armadilhas feitas por "outros seres", na busca por um "quarto do desejo", etc. Pensando desta forma, a constituição destes valores do Stalker pode ser entendida como uma ligação com as possibilidades de encantamento através do percurso.

Tendo esta consideração em vista, identifico um outro "arrastamento": ao abrir-se para esta espécie de dimensão "mágica" da experiência, a transurbância transpõe a abertura aos fluxos e aos acasos promovida na prática da deriva para sua possível potência de encantamento.

\footnotetext{
${ }^{29}$ Parece haver uma convergência entre o pensamento de Careri e de Gilles Deleuze quando o filósofo nos fala sobre sua noção de moral: "Ou a moral não tem sentido nenhum ou então é isto que ela quer dizer, ela não tem nada além disso a dizer: não ser indigno daquilo que nos acontece" Cf. DELEUZE, 2013, p. 151.
} 
Assim sendo, existe um outro aspecto desta errância que ajuda a entender os desdobramentos que a diferenciam da deriva: o reconhecimento de uma relação importante com a ação de parar.

Careri diz que "procura-se construir uma ponte entre o caminhar e o parar, entre o ir e o ficar - quem sabe entre o nômade e o sedentário [...] uma pausa em um percurso que não pode parar" (CARERI, 2017, p. 7). Tal afirmação funcionaria como um momento de abertura para possibilidades de reflexão sobre a experiência e torna-se ação fundamental neste processo de retomada de posições, de reconhecimento das possíveis alianças com o território e de certo cuidado com os lugares que possivelmente podem ser atravessados.

Estas alianças com o meio (CARERI, 2017, p. 16-17), possibilitam o reconhecimento de vazios entre os limites que definem as zonas experienciadas. Atravessando-os pela abordagem de Simas e Rufino, penso que eles se configuram como síncopes, pois são, como dito, as possibilidades de negociação, de drible inesperado no espaço. Assim, saber parar, estabelecer possíveis alianças e produzir as síncopes nos vazios se constitui como parte de um processo de encantamento deste percurso, na medida em que são os momentos de incerteza, de indefinição do caminho a seguir, mas também de expectativa, do que pode devir dos fluxos da experiência.

Já no Brasil, podemos identificar, sobretudo no campo da arte contemporânea, a utilização de errâncias por diversos artistas. ${ }^{30}$ Tendo a diversidade destas práticas artísticas em vista, reconheço em uma delas similaridades com a transurbância. Similaridades estas que guardam potência para provocar um terceiro "arrastamento": o trabalho Notícias de América (2011), do artista Paulo Nazareth.

Este trabalho tem uma duração de mais de um ano. Trata-se de uma pesquisa de campo (MAZZUCHELLI, 2012, p. 16.) que consiste em uma travessia por toda a América Latina a pé. Sua ascendência indígena, italiana e africana, desdobra-se em uma questão racial que se torna mote de muitos de seus trabalhos - como Cabelo (2006), Dente de Elefante (2007), Cara de Índio (2007) - no entanto, o artista tem no caminhar uma ação fundamental de crítica sobre o território. Nazareth diz:

\footnotetext{
${ }^{30}$ Cf. SOMMER, 2015.
} 
Meu conceito de pátria todos os dias se expande... nascido no Brasil sou latinoamericano, sendo latino-americano sou também mexicano... sou parte de cada terra por onde pisaram meus pés... não há como separar estas terras com uma linha imaginária chamada fronteira... talvez seja por isso que levantaram o muro ao norte: uma tentativa de impedir que o México siga sendo México para dentro dos Estados Unidos (NAZARETH, 2012, p. 93).

A questão que interessa se refere ao tensionamento da noção de limite, de fronteira, sobretudo por meio do caminhar. A forma com que o artista se deixa levar pelo devir, por esta constante produção de diferença dos locais sobre as quais caminha parece ser a chave para flagrar certa confusão identitária dos territórios, zonas de incerteza, inclusive de si mesmo, conforme coloca Janaina Melo:

[o artista] empreende no tempo da caminhada um certo grau de absoluto. Entrecruza pedaços de objetos, textos e imagens para, a partir deles, compor narrativas e situações. O que importa no processo não é necessariamente o resultado - objeto ou trabalho de arte original - mas a busca pela desorganização das coisas, das pessoas e de si mesmo (MELO, 2012, p. 120, grifo meu).

Como forma de mostrar este processo, Nazareth constrói textos, fotografias, recolhe objetos, fragmentos de seus percursos, que montam, desmontam e remontam narrativas. Por vezes posiciona-se ou posiciona elementos em locais imprevisíveis e improváveis, que tendem a tensionar os limites dos territórios atravessados pelo artista ao longo desta trajetória pela América.

Tal modo de operação de Nazareth conecta-se diretamente com o valor ao processo e ao desconhecido, que identifico na transurbância. O processo de busca por uma desorganização das coisas, das pessoas e, assim, de si mesmo, pode ser vinculado à abertura ao que o caminho, em si, pode trazer à experiência e, desta forma, enxerga o desconhecido dos devires, que daí se desdobram como potência de atualização destas zonas. Além disto, parece-me que este trabalho assume a complexidade gerada pelos arrastamentos que a transurbância faz da deriva, pois está aberto às confusões de identidade (estranhamento), atento aos fragmentos (sobrevivências) e imerso em táticas de movimento imprevisível ou de deseducação (encruzilhadas).

Para além desta convergência importante entre a prática de Nazareth e a de Careri - fundamental para entendê-las como ações que praticam o percurso como forma de arte e, assim, de crítica -, penso que as relações estabelecidas nestas errâncias realizam dois movimentos fundamentais para a discussão sobre as 
transurbâncias enquanto prática de atualização em dispositivos: elas expõem suas linhas de estratificação na medida em que produz síncopes no espaço, dribles, desvios que tensionam suas formas de experiência mais tradicionais. Tal produção cria linhas de atualização, isto é, produz um outro "furar" nestes territórios. Um "furar" encantado, que valoriza o que pode ser produzido de encantamento por meio de dimensões desconhecidas e fluxos imprevisíveis do caminho. Apropriando-me das palavras de Simas e Rufino, seriam Furos de Encruzilhada.

Transpondo esta discussão para o dispositivo muro do ramal ferroviário Santa Cruz, penso que é possível reconhecer nestas práticas a potência para gerar outras linhas de força através do ato de construir as narrativas e, desta forma, produzir suas atualizações.

Os furos engendrados hoje no muro da ferrovia configuram "fenômenos de interestratos", falando nos termos de Deleuze e Guattari. Mesmo que exista algo neles de espontâneo, que alisa estes estratos urbanos, há uma tendência ao regime de estriamento, que, por sua vez, opera a partir do medo e da insegurança de passar em tais locais e põe em questão a potência real de liberdade que estes furos possuem. Neste sentido, a prática da transurbância, entendida com todos os seus arrastamentos da deriva, parece ser uma forma de produzir outros movimentos através de sua operação por encruzilhadas nas síncopes do dispositivo muro do ramal ferroviário Santa Cruz.

A busca de uma esgarçamento do caráter funcional de tais furos através da transurbância, por fim, configura-se como uma operação na condição Entre: é uma via de apreensão e compreensão que opera a partir da alteridade, gerada no afeto pelo desconhecido e pelo encantamento das encruzilhadas, num espaço estabelecido Entre termos, isto é, num espaço de movimento que dribla os limites destes muros, nas suas síncopes. Neste caso, a narrativa que será apresentada, configura-se como uma terceira escrita afetiva e poética que pode ser entendida, no limite, como uma busca por racionalidades alternativas, como diz Ana Clara Torres Ribeiro:

Indo um pouco adiante, pergunto se o julgamento veloz, propício à leitura instantânea da vida urbana, criaria obstáculos à interpretação dos mediadores e das mediações, posicionados entre ação social e espaço herdado, que costuram, com fios tênues e tentativos, fraturas e feridas produzidas pela ação dominante. Uma costura que possibilitaria a corporificação de racionalidades alternativas (RIBEIRO, 2010, p. 30, grifo meu). 


\subsection{Furos de Encruzilhada: atualizações no Encantado}

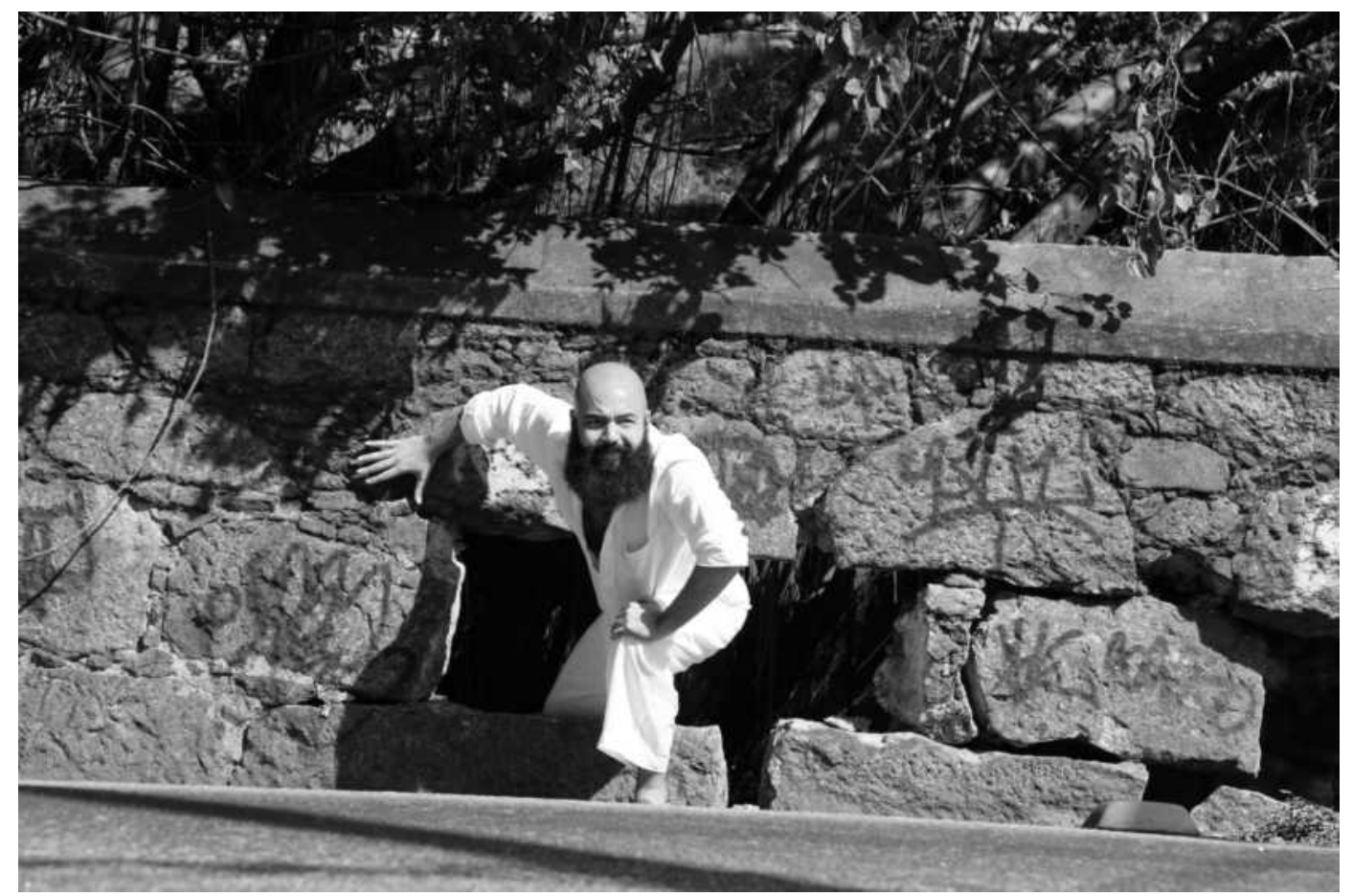

Figura 44. Transurbar no meio, Encantado, Rio de Janeiro.

Suor, dureza e cerveja.

Estas foram as primeiras palavras que vieram à minha cabeça ao cruzar a primeira esquina. Abri alguns botões da minha camisa, pois o sol me lembrava que os terreiros suburbanos do Rio de Janeiro precisam de ações de despressurização, de drible diante das energias que os incendeiam por dentro.

Encantado é o nome do bairro. En-can-ta-do. Encantado.

Uma fala embolada me veio aos ouvidos. Percebo que há uma discussão no bar. De um lado, um homem embriagado, a mim familiar, do outro, homens que aparentemente o caçoavam. A mim soou claro que os segredos do Encantado residiam na energia que aquelas falas emboladas carregam. Diante do conjunto de palavras que não conseguiam ser pronunciadas corretamente, entendi a mensagem do homem. Ele procurava liberdade para estar como quisesse.

Energia e força do encantamento incorporada nas ruas.

Encantados acontecem, para Simas e Rufino, nas encruzilhadas.

Sabendo disto, segui em direção à ferrovia à procura destas falas emboladas, destas encruzilhadas. 
O trânsito intenso. Nestas margens ferroviárias o fluxo de carros é uma espécie de relógio. É de manhã. Parei no sinal de trânsito ao lado da ferrovia. Me detive com a torre de energia do ramal e com o espaço gerado em sua base, concretada aos muros.

Uma possibilidade de síncope.

Um convite ao risco do vazio em um local que me era familiar, mas não explorado desta forma. Olhando de longe, era possível perceber seu apoio estrutural, formando uma rampa onde era possível se aproximar dos muros e, assim, desta síncope.

Sinal verde. O suor descia pelas costas. Estava calor e eu queria movimento.

Sinal vermelho. Ainda parado, ouvi o soar do vento: atravesse, dá para entrar lá.

Sem hesitar, fui em direção ao beco que me levava ao alcance do que queria.

A certeza de que eu iria pular sem problemas se desfez na primeira pisada na rampa de concreto. Pés tortos. Desequilíbrio. Pedra. Pedrar na mão.

Parei e, inevitavelmente, pensei, junto com Careri, sobre a importância de serem construídas alianças no meio. Saber construir alianças laterais e de superfície como forma de apoio, de incorporação de forças.

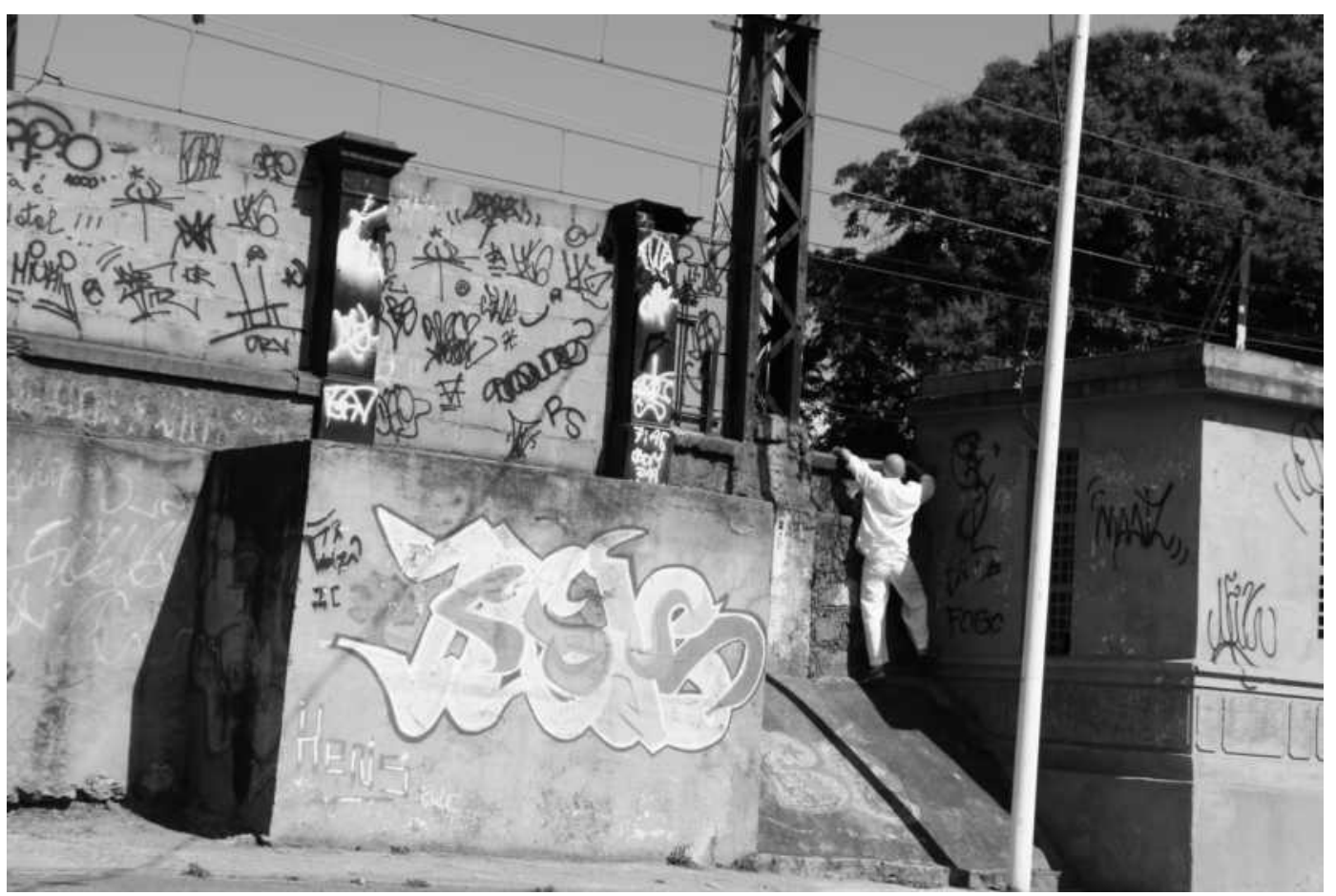

Figura 45. Alianças de apoio no transurbar, Encantado, Rio de Janeiro. 
O vento me acompanhando: segure na parede, apoie na janela ao seu lado para conseguir chegar ao muro.

Apoie no muro.

Ali, pude sentir o foco de um dos incêndios aos quais os subúrbios estão submetidos. Minhas mãos sentiram na quentura das pedras a intensidade da energia de transmutação guardada neste elemento urbano. Fechei os olhos por um momento e me perguntei: quanto de fogo estes muros guardam?

Fogo é onde abrem-se as possibilidades de encantamento, de transmutação, de incorporação de forças.

Encostar meu peito no muro.

Logo percebo que o tempo do movimento que eu fazia não é o tempo do vento, mas o tempo do fogo.

Preciso ir mais rápido.

Fogo que queima a mão, queima o braço, queima o peito, só não queima os pés, pois as sandálias me protegem. Arfar. Peito arfa. Trilho. Vento. Céu. Consegui.

Respirar.

Do outro lado, curiosamente, pude perceber que o som do fluxo de veículos já não era o mesmo. Certa paz, misturada com uma inquietação que foi arrastada pela "quase queda" diante da quentura dos muros. Misturas acontecendo no meu corpo.

Como estes espaços arrastam este fogo, sentido a pouco?

Logo a resposta: um trem passou a menos de dois metros de mim e me fez cair no chão. Mão no chão. Suor na ponta do nariz e esperar grudado à irregularidade seca e afiada das pedras que cobrem o chão.

O medo, no entanto, não se instaurou no meu coração.

Minha mente voou e pensei em como a deseducação diante do comportamento socialmente aceito, hegemônico por aqui, aparece enquanto potência com diferentes caras em pensadores que arrasto comigo: o acontecimento, a errância, a encruzilhada.

Utilizadas aqui, estas diferentes caras permitem que os "incêndios" causados pelos muros na cidade deslizem através deles, atravessem-nos. Fogo.

Embora o trem já estivesse passado, permaneci deitado com a mente nestes pensadores. A incorporação de uma ação de risco diante de situações urbanas como esta é um arrastamento transversal deste fogo que queima as calçadas, ruas, 
casas e, sobretudo, os sujeitos que transitam ao longo do ramal ferroviário Santa Cruz. Sol. Suor. Calor. Abrir encruzilhadas.

Levantei, respirei o ar seco e empedrado destes locais e atravessei a ferrovia.

A vontade de parar no meio dos trilhos de trem foi grande, pois ali residia a fonte de todo o estriamento gerado pelo ramal. A lógica de deslocamento, de otimização do percurso.

Rodar no meio do ramal e olhar para cima por alguns segundos.

Percebi que este poderia ser um dos lugares mais calmos da cidade.

O sol, aqui no meio, tem uma brisa para atenuar seu efeito, uma vista ampla do subúrbio carioca e possibilidades de encontrar sombras a poucos metros.

Pela primeira vez, me dei conta do vazio no qual estava inserido. Na verdade, penso que o produzi, na medida em que me abri ao afeto por ele. Atravessei-o e ele me atravessou.

Por alguns minutos nenhum trem passou e eu, ainda um pouco tonto e suando, fui em direção a outra margem.

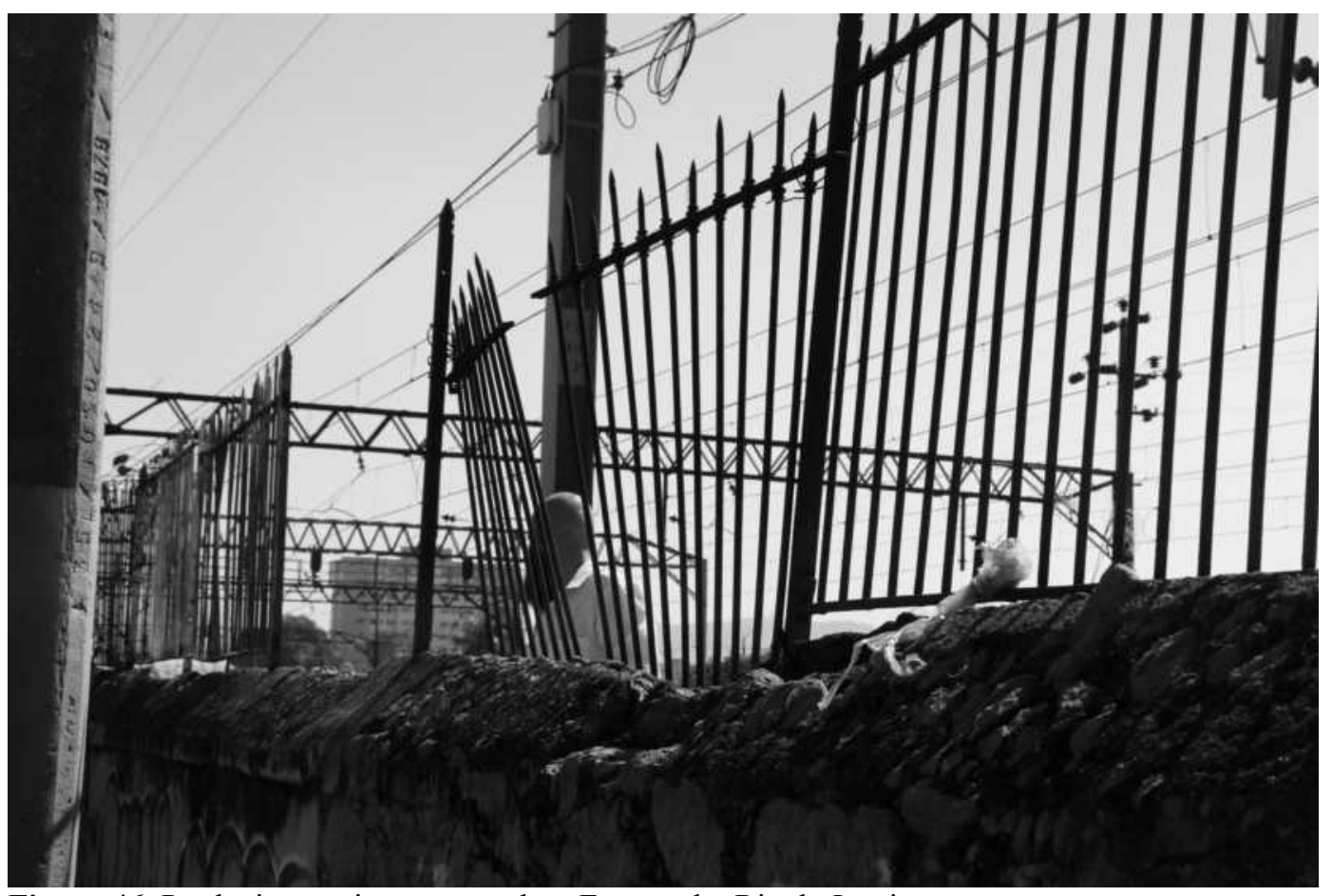

Figura 46. Produzir o vazio no transurbar, Encantado, Rio de Janeiro.

Existem possibilidades de parar na cidade.

Mas fiquei impressionado com a quantidade de pessoas que, mesmo paradas, passam diariamente neste local sem conhecê-lo. Via de longe as cabeças nas 
janelas olhando adestradas para o Rio de Janeiro desdobrando-se a seus olhos. Elas não conhecem a tranquilidade deste lugar.

Logo, outra mensagem: Apoiar e subir no muro.

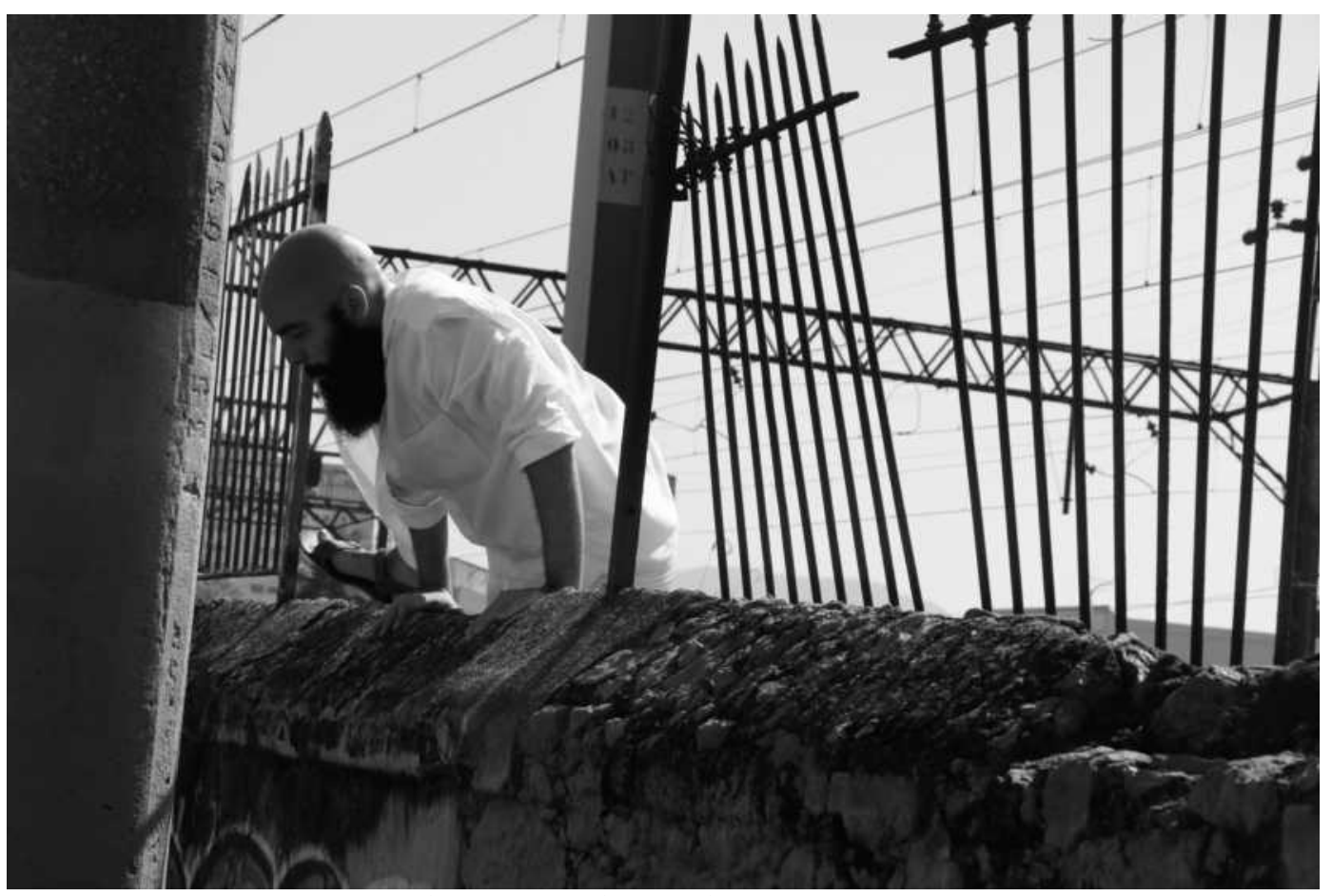

Figura 47. Vertigem no transurbar, Encantado, Rio de Janeiro.

Imediatamente, outro corpo se instaurou. $\mathrm{O}$ equilíbrio dos órgãos que no minuto anterior estavam garantidos, foram explodidos, pois ao olhar o lado externo vi que a altura era maior do que a interna.

Vertigem. Balancear, tremer, suar, rastejar e sorrir. Conheci estas ações, em ordens diversas ao longo de alguns segundos. Que segurança é essa agora, Daniel? Por um instante pensei em descer, mas o desejo de ficar nesta síncope e alimentar o fogo que passava pela sola das minhas sandálias era maior.

Como as pessoas não experimentam estes espaços daqui? 


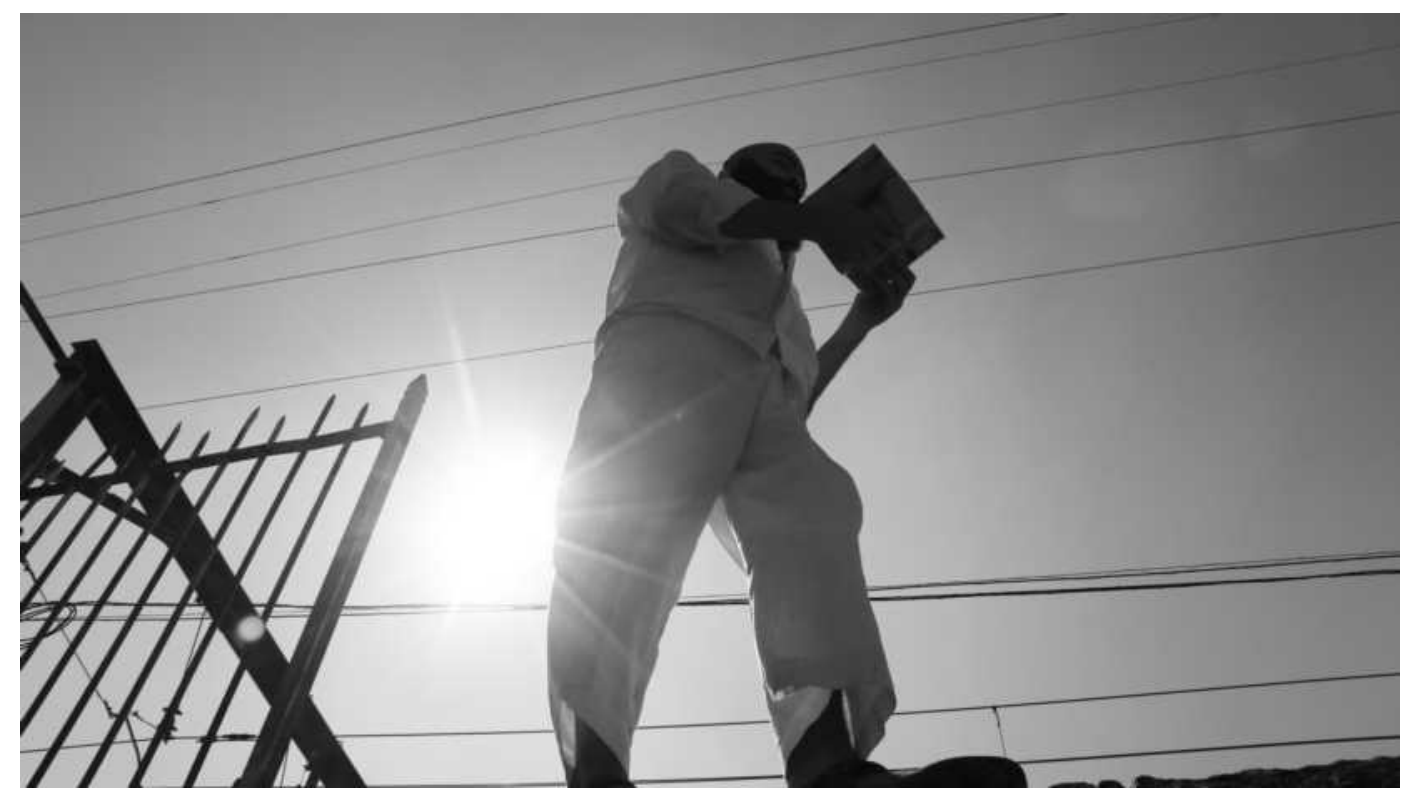

Figura 48. Embolando falas no transurbar, Encantado, Rio de Janeiro.

Lembrei-me das falas emboladas proferidas pelo homem embriagado na esquina em que passei e de sua potência de mobilização e produção de energias.

Pedi ao Leandro, que estava comigo em silêncio, um livro: Corpocidade: debates, ações e articulações.

Ler trechos aleatórios, sem se apoiar, eu ouvi.

“Página quarenta e oito [...] substituir a interpretação pela experimentação [...] como estrato, o corpo informa e comunica sensorialmente imagens [...] o $\mathrm{CsO}$ promove desarticulação no conjunto de estratos [...] Ruptura a-significante; Acontecimento". 31

As palavras saiam da minha boca junto com o fogo que queimava meu estômago na tentativa de me adaptar à energia do vento que me atravessava por inteiro. Que corpo é esse que não suporta o desequilíbrio? Experimentar outros corpos. Devolvi o livro e fiquei pensando sobre como estar de pé nas síncopes destes muros expõe as condições de disciplina a que meu corpo está sujeito na cidade. Quantos muros me são impostos?

Desequilibrar, sincopar, bambear, eventualmente, cair, são possibilidades que emergem da experimentação dos furos e me possibilitavam localizar estes muros. Nos pés, no pescoço, na cintura, na cabeça. Produzir encruzilhada. Lutar por acontecimento. Abrir-se para o encantamento. Para a magia.

\footnotetext{
${ }^{31}$ Cf. MAGNAVITA, 2010, p. 48
} 


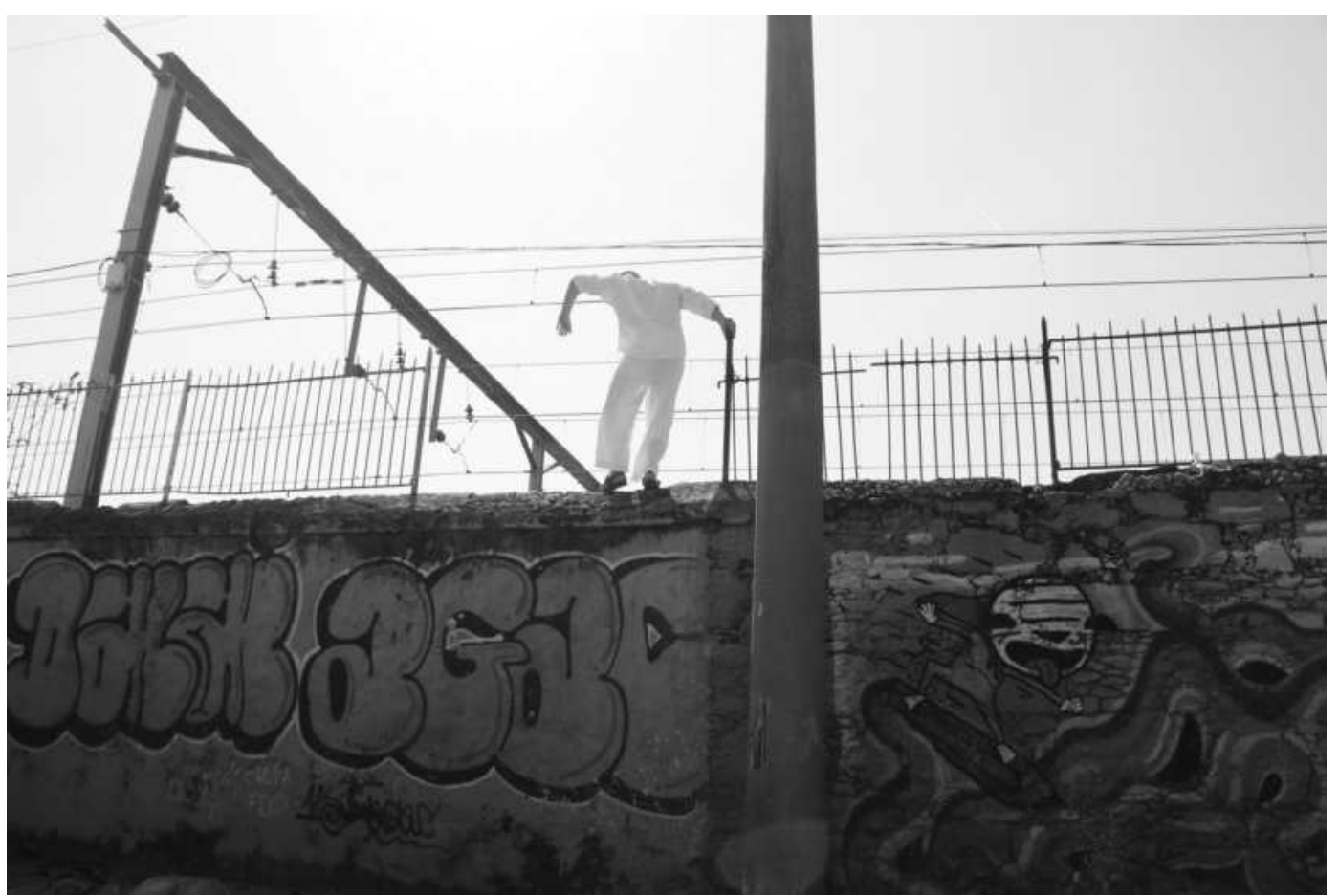

Figura 49. Experimentando desequilíbrios, Encantado, Rio de Janeiro.

Tentei virar o corpo para sentir o vento bater de frente ao meu rosto que pingava de suor.

Vi restos trêmulos abaixo do muro e percebi que não os tinha visto quando subi. Cacos de vidro, madeiras quebradas, lagartos correndo, relva invadindo.

A relva invade, nasce do meio, brota como eu sentia brotar meu corpo em síncope, em negociação com o vento.

Mover. Ver a relva.

Novamente, parar e fazer alianças com o meio. A relva em movimento falava do meu corpo e das possibilidades que só poderiam ser faladas quando experimentadas. Como ela, eu me colocava por dentro do vento, aliando-me em diferentes pontos desse muro.

"Cuidado para não se machucar, rapaz! Aí tem um monte de caco de vidro, um monte de entulho". Ao lado tinha uma oficina de carros e o homem falou comigo, preocupado. Não respondi. Leandro não respondeu. Mas aquela frase ficou ressoando na minha mente, "cuidado para não se machucar... cuidado para não se machucar...”. A lógica da proteção novamente se fazendo presente.

Me perguntei: o que seria cuidar neste local? Fazer alianças com a lógica de proteção não me parecia ser um caminho de resposta. Cuidar tinha a ver com lançar-se nestes vazios, nestes riscos; permitir os tropeços, os arranhões e tombos, experimentá-lo a partir de dentro; transformar isto em festa. 
Sentia isto na garganta, mas a voz não saiu.

Precisei lançar-me no vazio em busca deste cuidado.

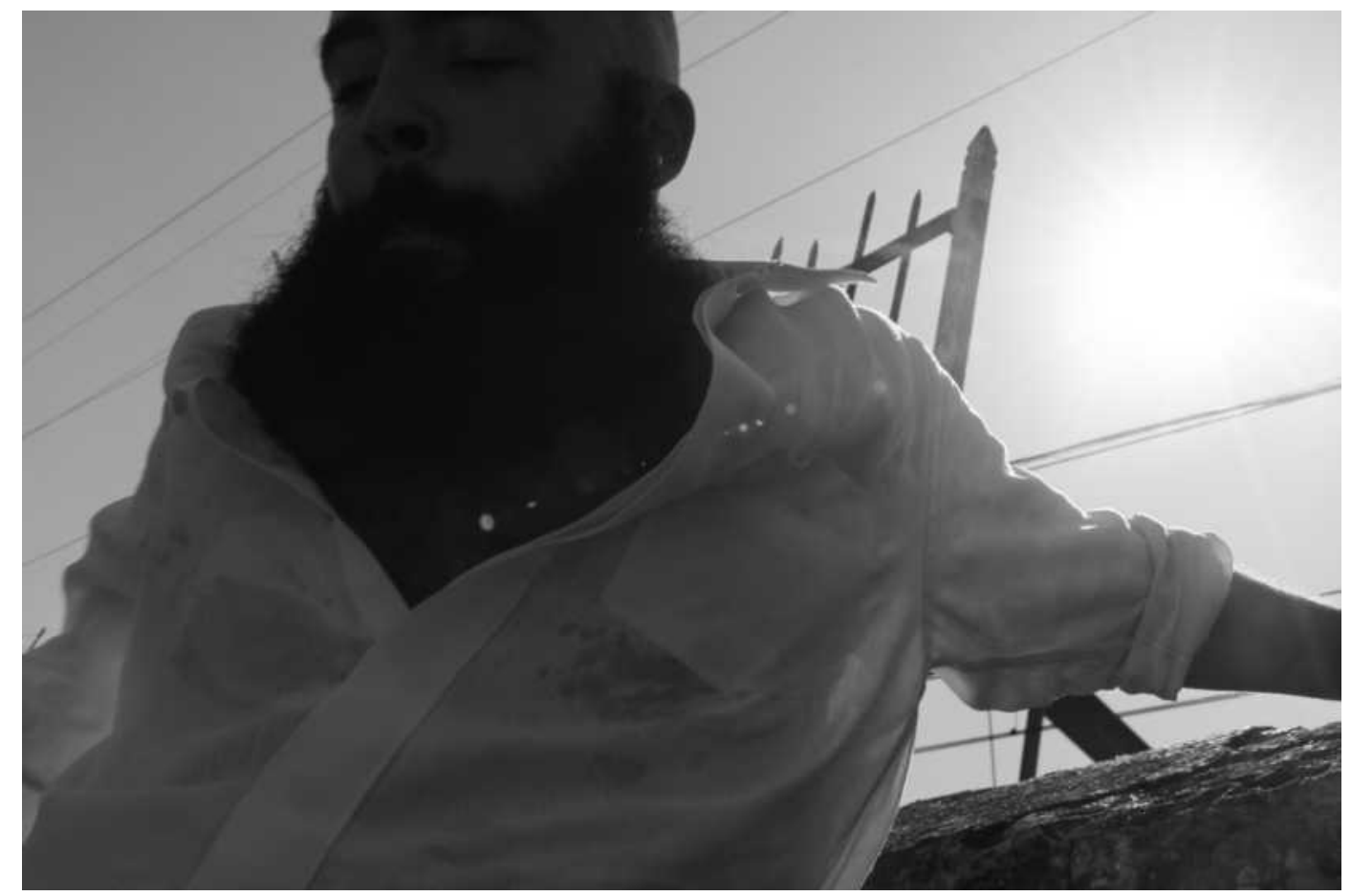

Figura 50. Lançando o corpo no vazio, Encantado, Rio de Janeiro.

A busca por falas emboladas foi bem-sucedida, pois percebi que no Encantado elas manifestavam-se nos bares.

Homens de repente embolando-se e rindo na calçada, quando eu percebi que para além dos tacos, mesas de sinuca, xadrez, não sei muito bem, era tudo sobre a diversão. Nada que foi dito, foi entendido. Não precisava. O conjunto de sons emitidos e corpos em movimento convocou a energia.

Tem momentos em que os muros somem e dão lugar a casas, bares, oficinas... Do lado de fora os acontecimentos são expostos, as energias convocadas e experimentadas, mas despertou-me curiosidade pensar em como acontecem os encontros entre estes lugares e o muro que acabei de encantar.

A parede de fundos do bar que eu passava era tomada de informações: bebidas, copos, santos, flores. Não evitava mostrar que por trás daquilo estavam os fundos, a cozinha, a área de serviço, o que, comumente, não poderia aparecer para a rua. Estavam de costas para os muros.

Os muros eram fundos.

Muros-fundos. 
Percebi o quão fundidos estes muros estavam a estas casas, invisíveis para todos. Como ver os muros virado de costas?

Me senti vivo, no entanto, sem o desejo de virar as costas para os muros, queria olhá-lo de frente, experimentá-lo enquanto mediador das minhas relações com o espaço.

A sede aumentou, mas me guiei pela mensagem: seguir contra os carros. Depois subir no muro.

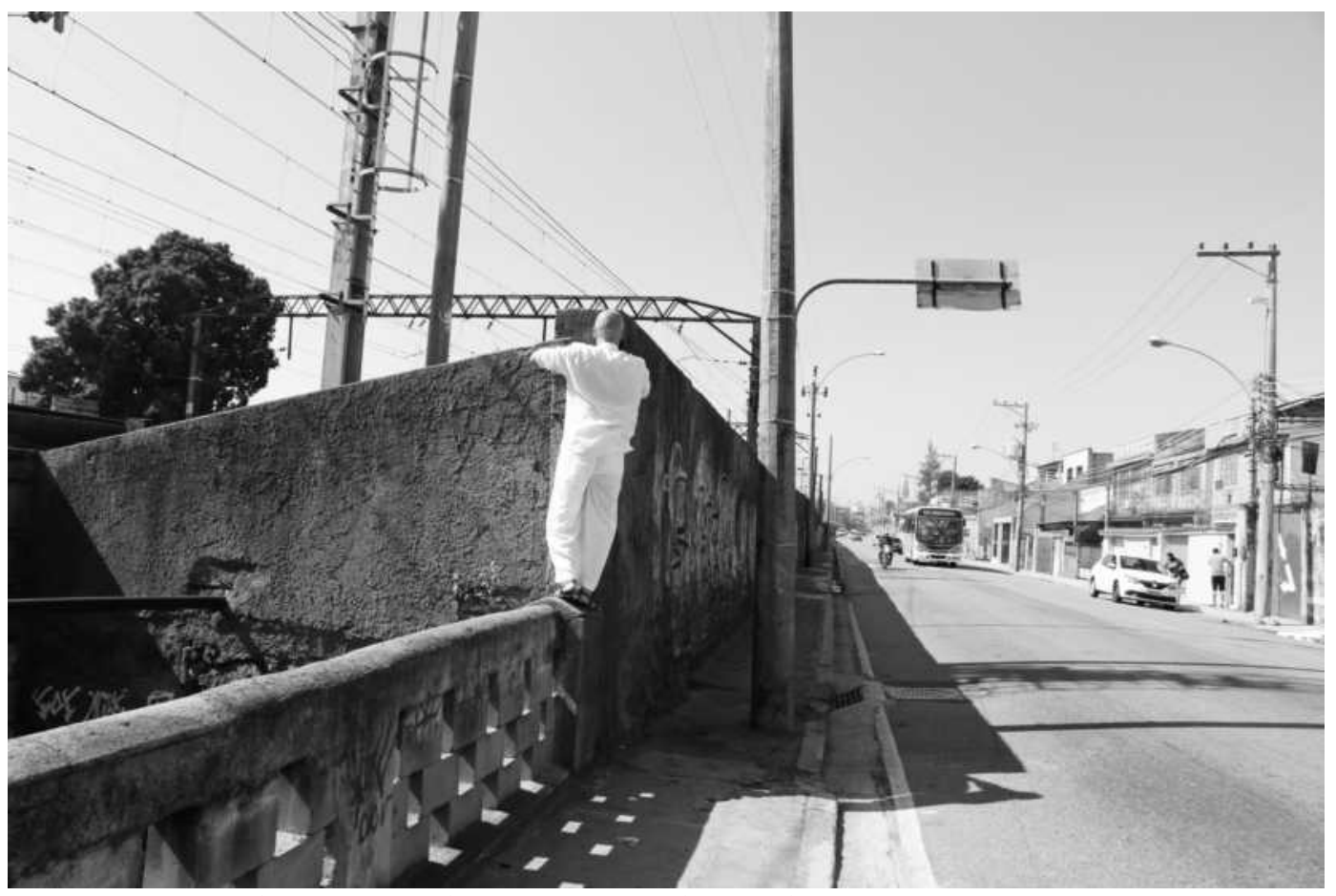

Figura 51. Imitando os estratos do muro, Encantado, Rio de Janeiro.

Logo uma possibilidade.

Subi e logo abaixo dos meus pés senti água. Um rio atravessava, lento e cinza, pelos fundos da ferrovia. Água que fura, é furada por territórios e não sai ilesa. Arrasta, é arrastada e mostra estes arrastamentos nos seus tons de cinza. Fluir.

Me peguei pensando sobre estes cinzas em mim, pois virei a cabeça e eu estava ereto, com o corpo colado nos muros. O fogo queimava pela blusa, mas o corpo pedia esta aproximação.

De quantos cinzas eram feitos estes muros?

Imitar os estratos, como diz Deleuze ${ }^{32}$, faz parte da construção de um corpo que desliza das significâncias e interpretações em direção às experimentações. Me vi

\footnotetext{
${ }^{32}$ Cf. DELEUZE apud MAGNAVITA, 2010, p. 49.
} 
experimentando este corpo duro, seco e fixo, e percebendo a minha capacidade de resistência ao calor.

Faz sentido a insistência no fixo?

Meus pensamentos já tinham voado a muitos lugares enquanto estava ali experimentando este outro corpo.

Parar. Num percurso que não para.

Fluxo de carros de um lado, o ritmo dos trens passando do outro e meus cinzas internos trazendo suas nebulosas do movimento.

Quando me vi estava no chão pisando na direção do vento junto com pedaços do muro que vieram comigo. Minhas mãos arrancaram partes do muro.

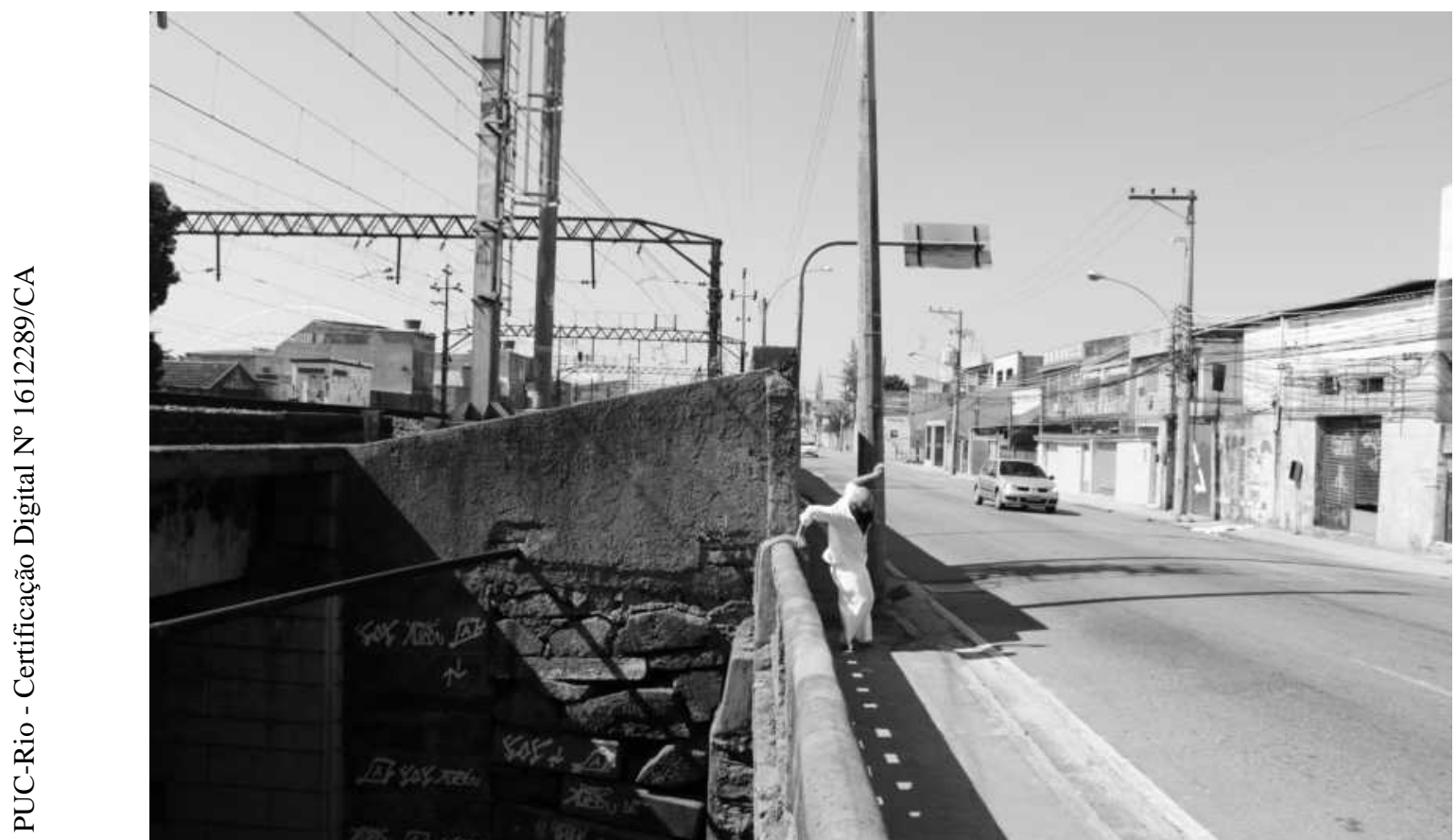

Figura 52. Seguindo o fluxo da rua, Encantado, Rio de Janeiro.

Novamente a pergunta: vale a insistência no fixo?

O devir, enquanto expressão do desejo, insiste em dizer, a todo momento, que não. Os cinzas destes muros não ficavam somente nas pinturas, pichações, propagandas de jogo de búzios que acontecem ao longo de seus percursos na cidade e sobrepõem-se à sua materialidade.

As pedras que vieram junto comigo mostravam este devir.

Expunham o quanto ele pode ser afetado, violado, quebrado. No entanto, flagram a ausência de abertura a este tipo de afeto, antirregras, anti-imposições.

Exatamente por isto, a ideia de ausência de movimento dos muros expressa no discurso do muro enquanto limite, barreira, experimentada durante a vida, não 
fazia mais sentido para mim e se refletia agora em um movimento intenso de sensações antilimites no meu corpo.

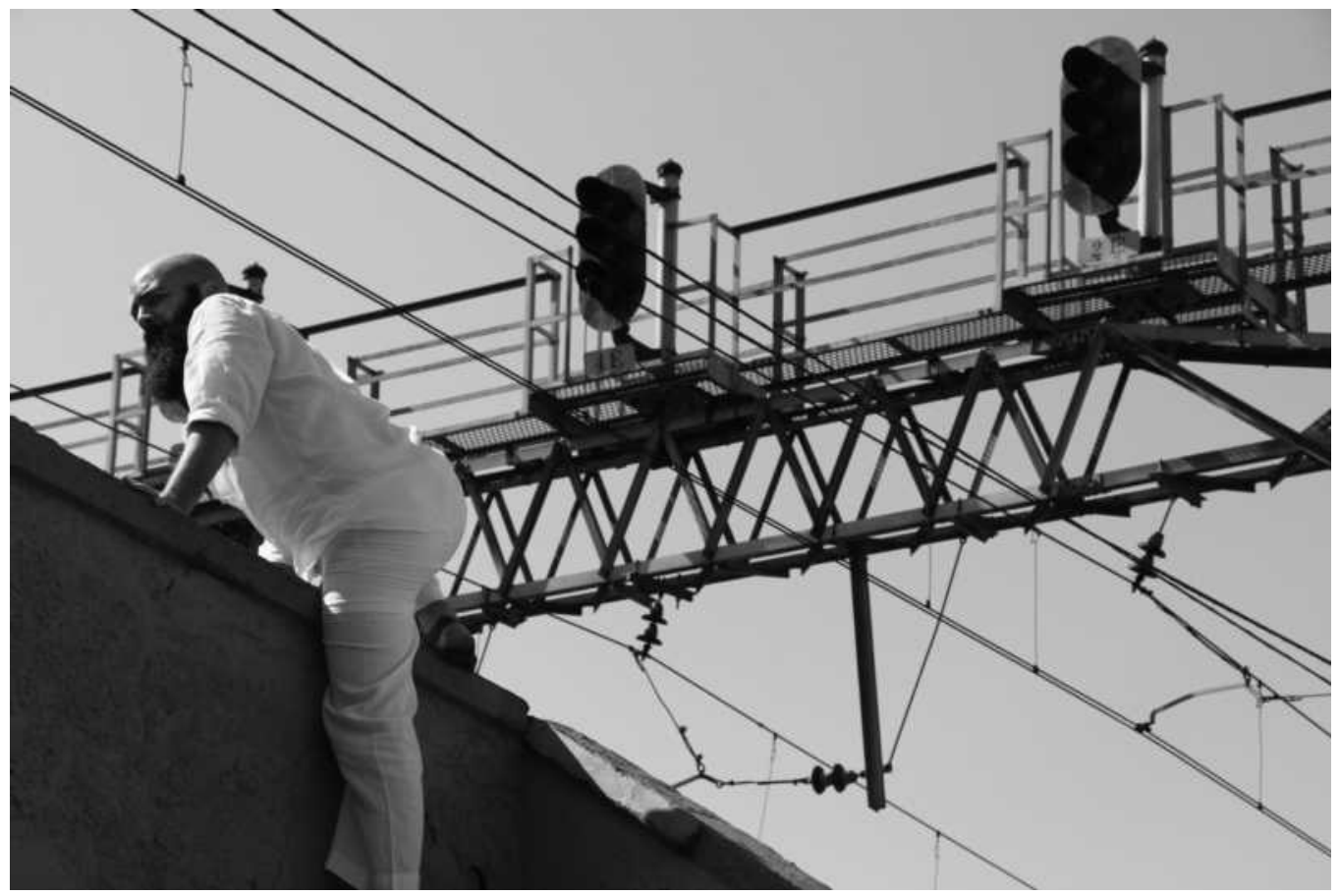

Figura 53. Produzindo uma síncope, Encantado, Rio de Janeiro.

Como pensar que os muros são fixos sem pensar assim sobre mim mesmo?

Pendurar a perna. Metade-Metade. Metá-metá.

O desejo de furar os muros que invadia o meu corpo por inteiro.

Este movimento acontece por dentro dos muros na cidade? Em que medida este furar, sentido pelo meu corpo, não é convocado por estes muros? Quanto deles pede, clama por ser furado?

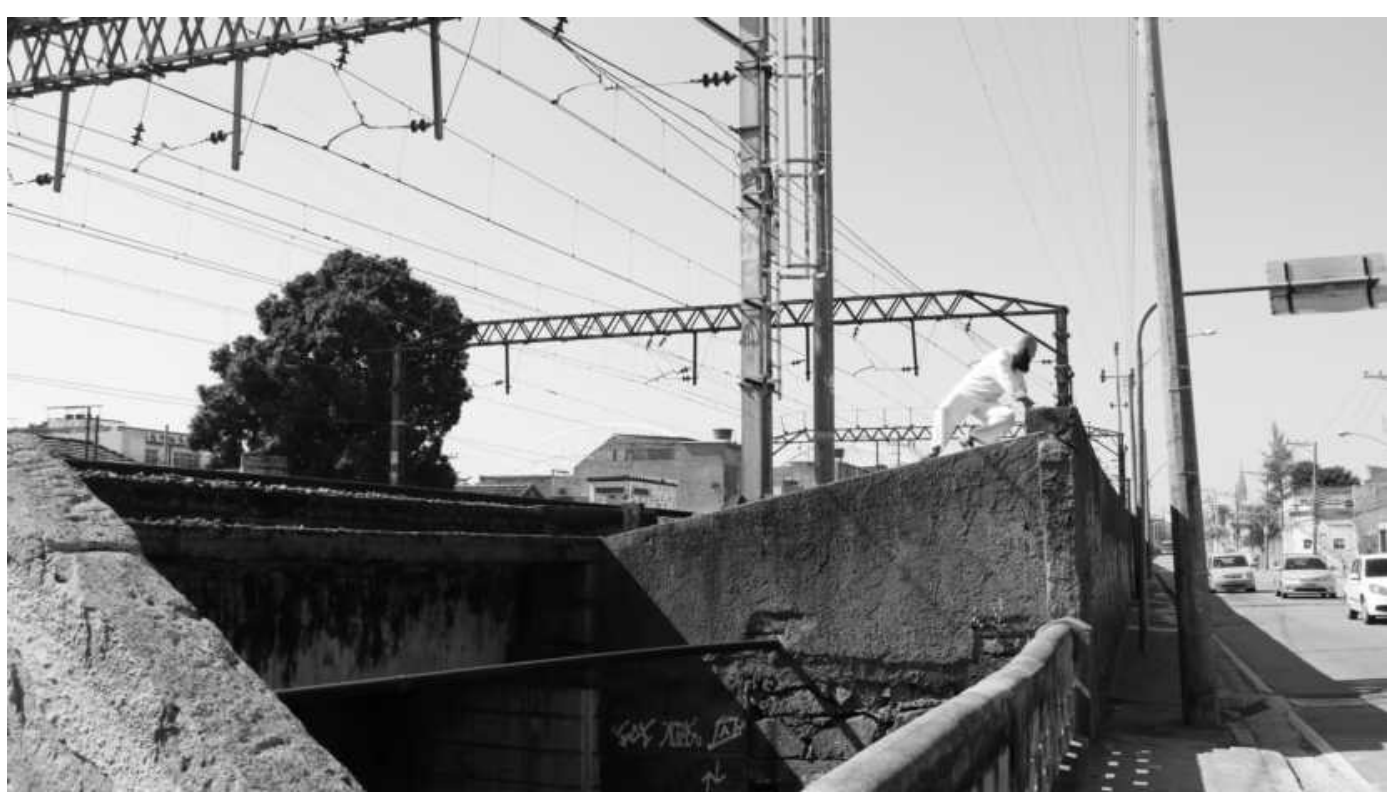

Figura 56. Agachamento e desequilíbrio, Encantado, Rio de Janeiro. 
A experiência de alteridade traça cada palavra destas perguntas. Sentir com o outro abre a possibilidade de entendê-lo a partir de outras bases.

Conseguir encontrar as síncopes, as possibilidades de drible para furá-lo e deixar o fogo fluir.

Várias ações brotavam: Agachar e rastejar pelo muro. Expor seus desvios e desequilíbrios. Meu suor misturava-se e arrastava os muros na minha blusa e corpo. Levantar os braços e mostrar vulnerabilidade nesta posição.

$\mathrm{O} \mathrm{Ka}{ }^{33}$, espírito da errância eterna, expõe a condição de movimento eterno na qual os nômades estão sujeitos.

Buzinas. Vontade de rir.

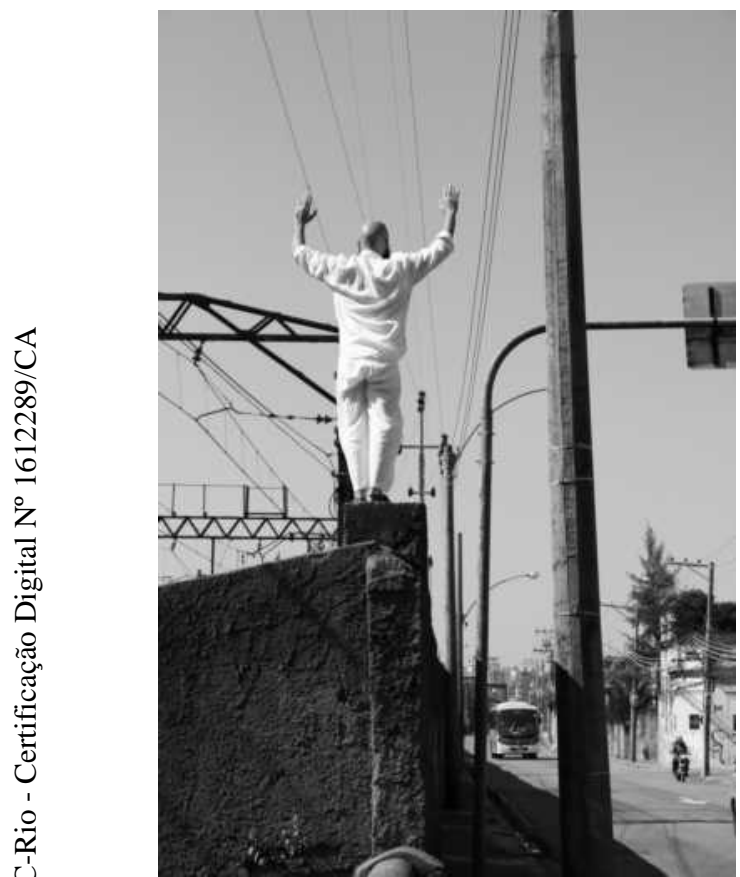

Figura 54. Símbolo da errância [Ka], Encantado, Rio de Janeiro.

Passo a passo, os muros iam me contando através de seu fogo nos meus pés, seus desejos de movimento.

Apontar para outras direções.

Driblar a retidão alterando o ritmo dos pés.

Girar com o vento.

Arriscar o tombo.

${ }^{33}$ Cf. CARERI, 2016, p. 59. 


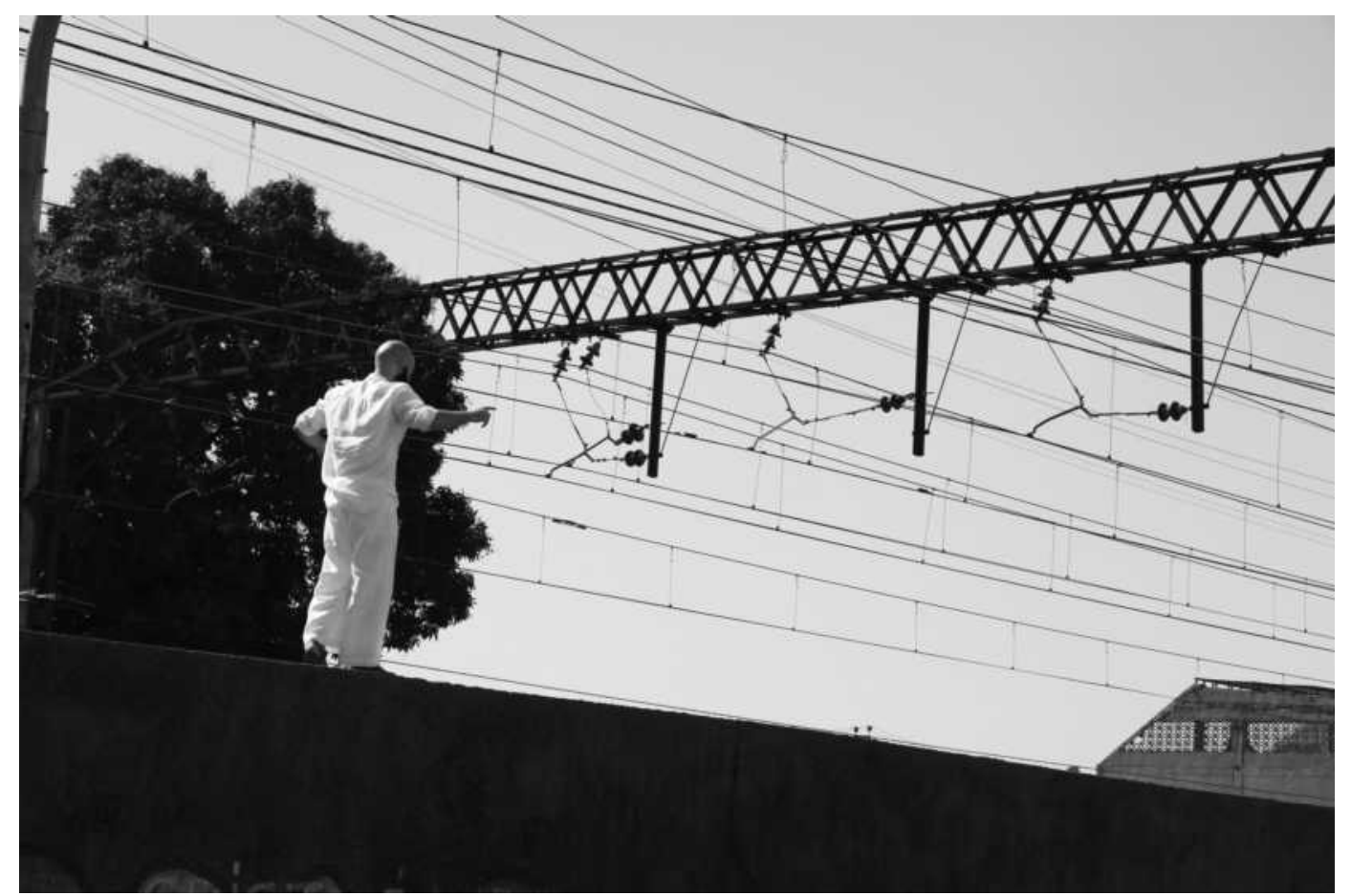

Figura 55. Arriscando outros ritmos, Encantado, Rio de Janeiro.

Logo, outra síncope.

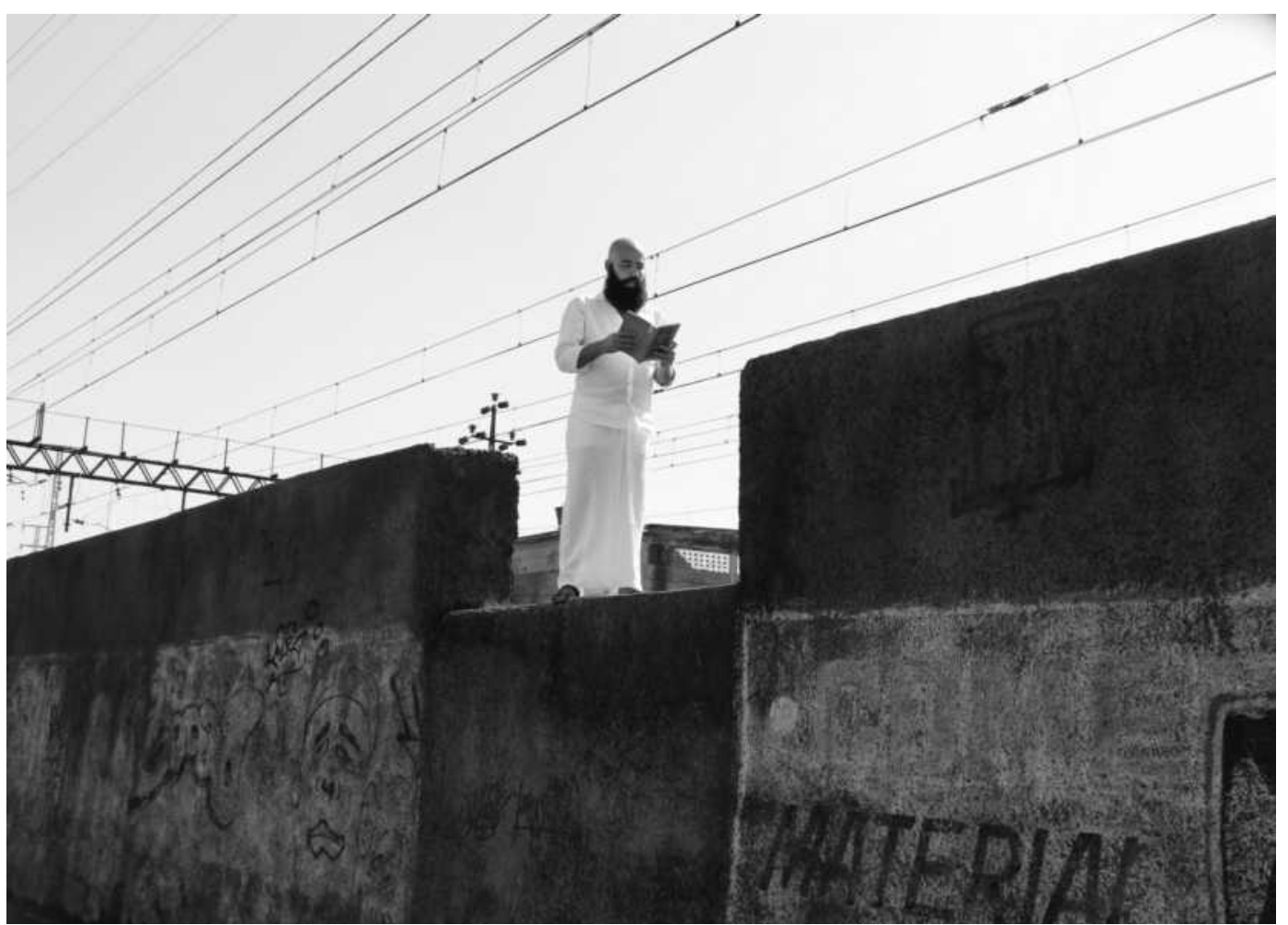

Figura 56. Palavras ao vento, Encantado, Rio de Janeiro.

$\mathrm{O}$ calor dos muros ignorava o couro das minhas sandálias e não pude evitar me expor a mais uma de suas encruzilhadas.

Pedi ao Leandro, que me acompanhava de longe, um livro. Recebi Fogo no mato de Simas e Rufino. 
Ler as palavras aleatoriamente para o grande vazio que me cercava, eu ouvi.

Mas na primeira frase não consegui evitar ler a sequência:

"Exu matou o pássaro ontem com a pedra que atirou hoje. A pedra lançada, as pedras trazidas, pedras que fundamentam os segredos das bandas de lá, as pedras que invocam saberes ancestrais e sustentam os chãos e os axés dos terreiros de cá. As pedras encantadas nos ritos de sacrifício dos corpos emanam energia vital. As pedras que fundamentam as invenções dos terreiros encantam-se a partir dos corpos. Assim, firmamos o ponto! O corpo, suporte de saberes e memórias, é também terreiro. O corpo é também um tempo/espaço aonde o saber é praticado. O corpo terreiro ao praticar seus saberes nas mais variadas formas de inventar o cotidiano, reinventa a vida e o mundo em forma de terreiros."34

Simas e Rufino diziam e eu repetia.

Não ouvi, de fato, uma palavra do que eu disse, mas as falas emboladas desemaranharam-se do meu corpo e me fizeram entender a presença dos muros enquanto terreiros.

Reinventá-los a partir da experiência errante era colocá-los como mediadores encantados, que aparecem e desaparecem para além de sua concretude, pois são também os fluxos que os cercam.

Incorporam-se em coisas e pessoas abertas ou não à sua presença.

Meu corpo, enquanto terreiro, incorporava estes fluxos e se permitia fluir para além dos limites colocados por estes muros.

À propósito, que limites?

\footnotetext{
${ }^{34}$ Cf. SIMAS; RUFINO, 2018, p. 53.
} 


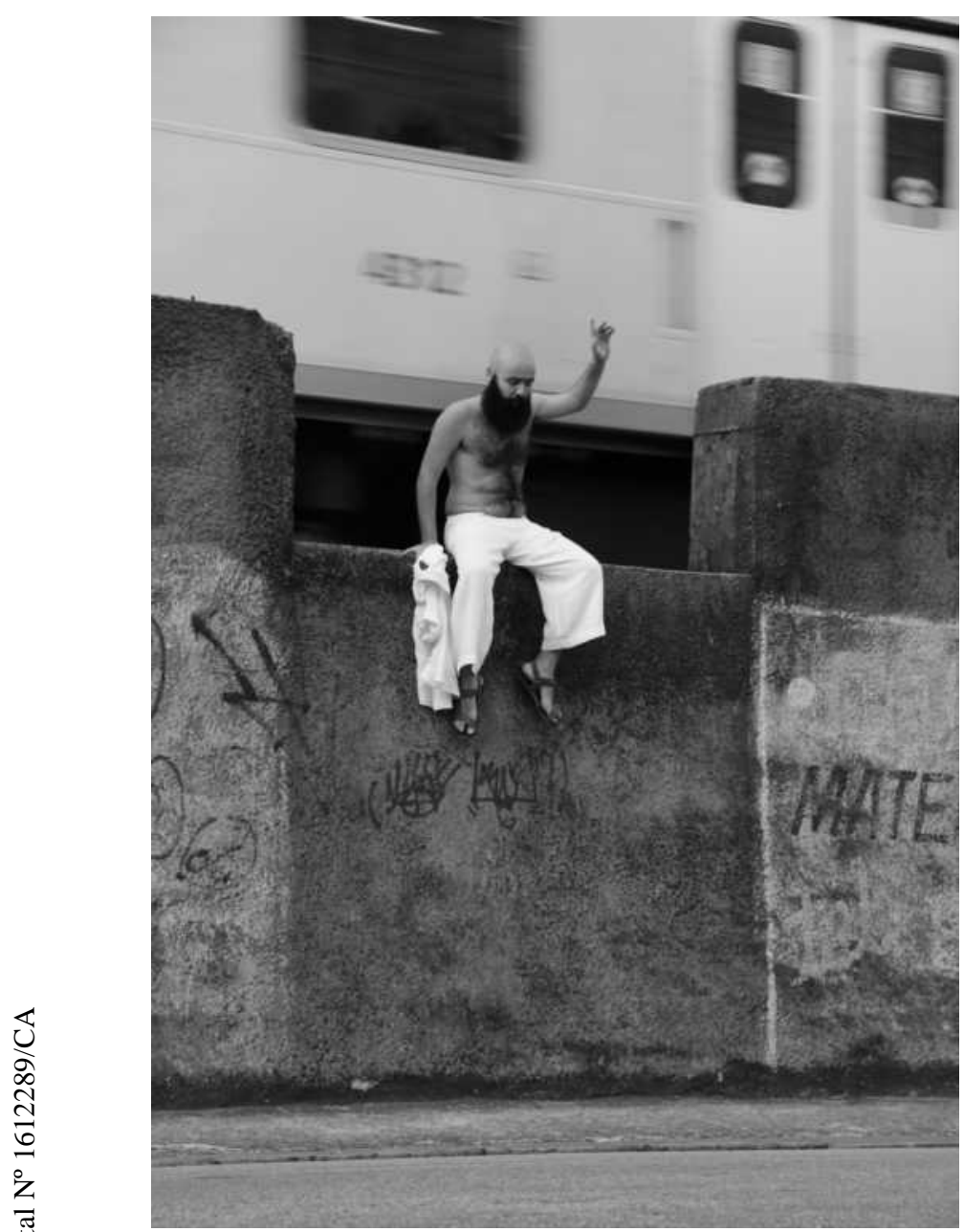

Figura 57. Fluxos à pele, Encantado, Rio de Janeiro.

Experimentar o risco se mostrou como a forma de criar e imergir em encruzilhadas. Sentir o encantamento dos fluxos.

O trem vinha e eu queria senti-lo na pele, sem proteção. Virar os limites para a banda do invisível, da magia do vento.

Deixar as cascas à mostra para a movimento, como estes muros fazem e não se percebe.

Expor suas condições de abertura aos Furos de Encruzilhada, a este furar encantado, de drible, de imprevisibilidade, que o reinventa enquanto presença na cidade.

O risco passava com leveza nas costas. $\mathrm{O}$ encantamento como sorriso nos lábios.

Levantei a mão para sentir na ponta dos dedos a força que meu corpo absorvia naquele momento só pelo fato de reexistir naquela síncope do espaço urbano. Como diz Ribeiro, a possibilidade de costurar, com fios tênues e tentativos, fraturas e feridas urbanas abre a possibilidade de gerar racionalidades alternativas. A ação em si, me pareceu caminhar neste sentido. 
Costurar fraturas urbanas através do erro, do risco, do vento, do encantamento e da poesia, em suma, um lançar-se, com afeto, no desconhecido.

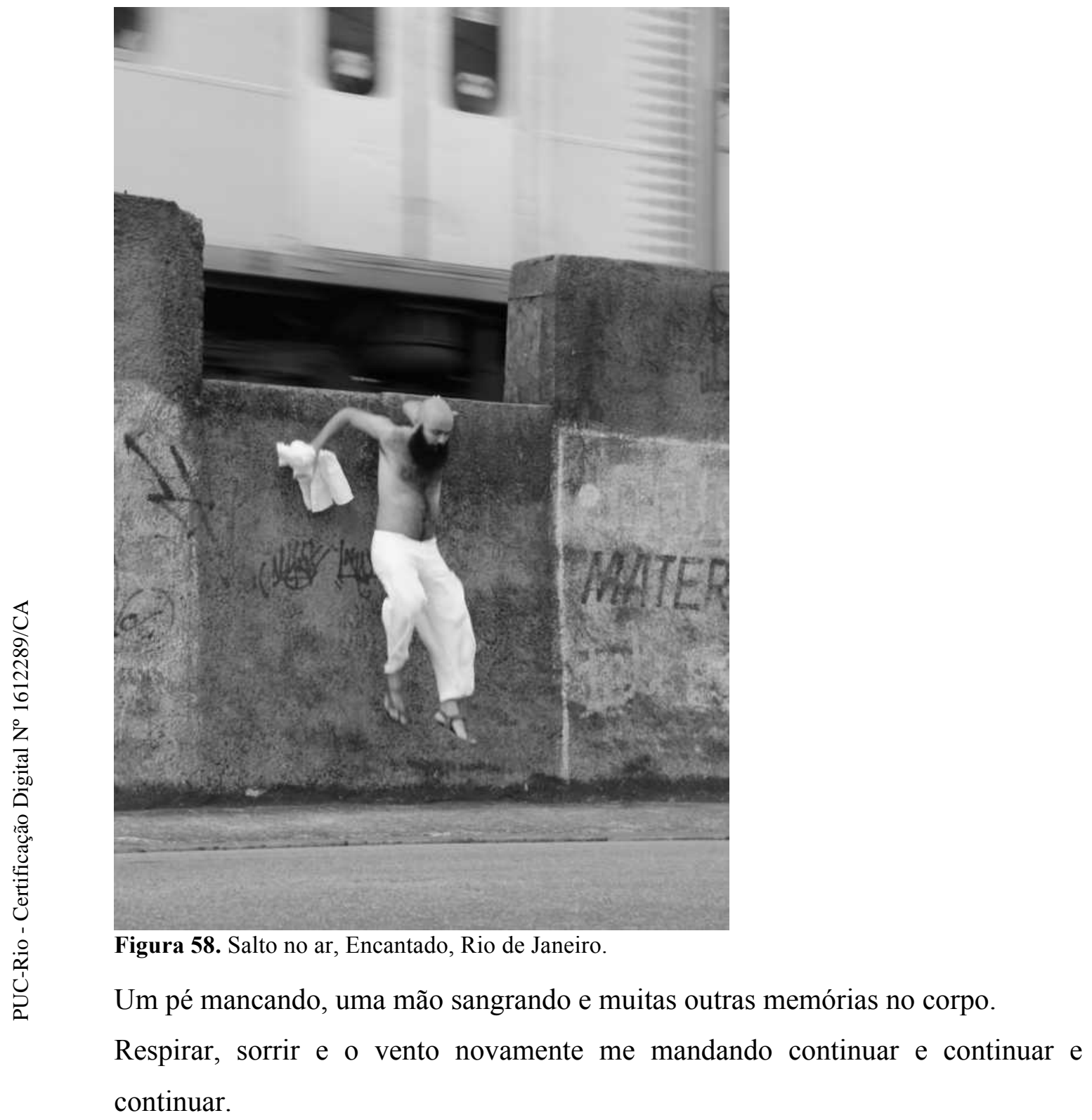




\section{Considerações Finais: sobre a condição Entre}

Persegui neste trabalho um caminho que busca um desvio à condição de limite que me foi imposta por este muro como morador destas margens do ramal ferroviário Santa Cruz. Imergir em uma condição Entre, foi uma forma de tentar encontrar outro modo de apreensão e compreensão deste dispositivo, que saísse de certo "conformismo" com a sua presença na cidade.

As errâncias, apresentadas aqui através de narrativas, foram o meio através do qual foi possível imergir no Entre nestas margens ferroviárias, apreender, compreender e produzir, mesmo que temporariamente, um pouco de suas complexidades. Assim, colocarei alguns pontos que, por hora, podem ser enunciados a partir desta experiência.

Estar nesta condição Entre foi possível sobretudo pela produção de alteridade que as errâncias promovem. Cidade e corpo tornam-se linhas de um mesmo novelo, afetando-se, atravessando-se a todo tempo. É uma experiência que permite uma relação de afeto maior com tudo que se movimenta, que escapa, porém não cessa de construir presença na cidade. Com esta abertura ao afeto, pude apreender e compreender a constante produção de diferença e as singularidades que dela derivam em mim e na cidade, mostrando que este muro pode ser muito mais do que sua forma.

Escrever sobre, ou melhor, com esta experiência me trouxe uma percepção do quão importante torna-se a identificação do lugar do narrador neste processo. No Entre não é possível estar isento às linhas de força dos dispositivos a que pertencemos e nos quais agimos; estamos Entre eles e influenciando diretamente em seu modo de operação. Assim, a experiência de alteridade, que tento transpor às narrativas, permitiu que eu ocupasse e desocupasse este lugar de protagonismo, deixando fluir outras vozes da cidade e permitindo que sua complexidade apareça.

Percebo que a discussão sobre os dispositivos tem um elemento chave que direciona seus modos de funcionamento: o discurso a eles associado. Ao sobrepor a minha experiência como morador destas margens ferroviárias com o discurso do controle e da proteção, historicamente atrelado aos muros, foi possível entender que há linhas de força sustentando as relações de invisibilidade, de medo, de 
insegurança e abandono que são construídas em relação a eles. Sendo assim, a produção destas narrativas aqui apresentadas atua na composição de outras linhas de força no dispositivo que buscam se desviar das estratificações geradas pelas forças hegemônicas e apontar caminhos de atualização. É possível identificar alguns deles a partir desta experiência:

Nas linhas de visibilidade, percebo que o muro perde seu caráter de invisibilidade e ganha materializações, tanto no que se refere à percepção de sua própria forma, quanto, e especialmente, na percepção de suas projeções ou incorporações em pessoas e coisas imediatas a eles. A abertura ao estranhamento mostra o quão estranhamente familiar pode se tornar um corpo que erra nestes estratos tão bem definidos da cidade, mas que parecem não existir e como esta ação traz o muro, enquanto limite e enquanto projeção ou incorporação, para um regime de luz.

A atenção para as sobrevivências guardadas por este muro, o faz ser visto a partir daquilo que esconde, que separa, que quebra, lançando lampejos, através destes restos, às formas hegemônicas, unitárias e homogêneas de vê-los. A imersão em encruzilhadas produzidas neste muro, apresentam outras possibilidades de "furar" a noção de limite e de vê-lo enquanto continuidade, abrindo-o para o movimento e para sua dimensão de encantamento através dos fluxos desconhecidos que o atravessam.

Nas linhas de enunciação ocorre um deslocamento das narrativas hegemônicas que produzem formas de falar deste muro reduzindo-o à ferrovia, isto é, invisibilizando-o enquanto dispositivo urbano e atrelando a ele o caráter funcional de proteção e controle do sistema ferroviário. As cartografias afetivas instauram-se neste dispositivo e falam com ele a partir das relações de afeto e devir geradas na experiência errática. Falar a partir do estranhamento do muro produzido na deambulação e mostrá-lo acontecendo em pessoas e coisas é mostrar um outro "murar" na cidade que vai além de sua concretude, é expor este muro em devir. Encontrar sobrevivências nos restos guardados por este muro por meio da deriva é conseguir falar através do que é abandonado, inutilizado e esquecido por ele e não através de sua força enquanto elemento de controle e proteção. Conseguir falar deste muro através das encruzilhadas produzidas nas transurbâncias é falar de sua potência de encantamento dos fluxos imprevisíveis 
através dos furos que podem nele ser produzidos, em detrimento de valorizar seu caráter de impedimento, de separação e corte na cidade.

Nas linhas de subjetividade deste dispositivo é possível perceber o atravessamento direto com as três primeiras linhas aqui colocadas. A experiência errática possibilitou uma construção provisória e singular do que Solà-Morales, juntamente com Odo Marquard, aponta como sujeito pós-histórico, aquele que convoca o risco, a estranheza diante do mundo e de si mesmo. Entretanto, um fato importante de se dizer é que este sujeito não se constrói na errância em si, mas, sobretudo, no processo de produção de suas narrativas. É um "si-mesmo" (DELEUZE, O que é um dispositivo?), como diz Deleuze, que não está dado e nem se encerra, mas dobra as linhas de força do dispositivo abrindo nele, conforme dito, possibilidades de experimentação. Neste processo é possível construir algumas linhas desse sujeito, materializá-las provisoriamente como feito acima. No entanto, ele está em constante processo de mudança e não se encerra nestas narrativas.

Neste sentido, os Muros, os Restos e os Furos funcionaram como linhas de relações em que a condição Entre pôde ser estabelecida. São relações entre as três dimensões foucaultianas o "Saber", o "Poder" e os "processos de subjetividade" que no dispositivo muro não são encerradas, são mantidas em aberto para outros (infinitos) arranjos, para outras (infinitas) alianças. Estar Entre Muros, Restos e Furos constitui-se, assim, como um apontamento para a condição de abertura às múltiplas atualizações que estes muros podem ter, a depender de cada sujeito que quiser correr o risco de imergir neste meio urbano.

Ao considerar isto, é possível pensar que estas errâncias podem ser utilizadas como vias de apreensão e compreensão de muitos outros dispositivos urbanos.

O dispositivo ferrovia: como operam os regimes de visibilidade e de enunciação e de que forma as errâncias poderiam produzir atualizações na ferrovia? Em que medida os muros que acompanham a ferrovia contribuem para uma relação de invisibilidade de longos trechos urbanos? Faz sentido ter muros, mesmo que precários, onde já se pode atravessar a pé a ferrovia? Sendo a ferrovia um meio importante de deslocamento na cidade, como outras relações de controle e proteção podem ser estabelecidas? Faz sentido ter controle nestas margens? Até que ponto? 
O dispositivo rodovia: como operam os regimes de visibilidade e de enunciação nas rodovias que são margeadas por muros urbanos? Em que medida a sensação de medo e insegurança, presentes nestas errâncias, constroem subjetividades nestas rodovias muradas? O que a lentidão, a desorientação e a incorporação das errâncias pode mostrar sobre o movimento da rodovia?

O dispositivo calçada: as errâncias revelam muito deste chão, deste terreno em que se pisa e mal se nota. Como podemos atualizar as calçadas? É um meio de experimentação em aberto.

São infinitos os dispositivos que podem ser experienciados e disputados através das narrativas urbanas, sobretudo, as errantes, que os desterritorializam por dentro, desmontando estruturas que, na contemporaneidade, carecem de movimento para acolher o diferente, as diferenças, que, por sua vez, não cessam de acontecer.

Diante desta constatação, penso que a condição Entre - este movimento do meio que nos atravessa e nos emaranha com a cidade, seus dispositivos e suas diferenças - associada às errâncias - estas experiências estéticas de alteridade e vias de apreensão e compreensão da complexidade urbana - colocam a oportunidade de se pensar outros modos de apreender, compreender e construir, no limite, a Paisagem, este grande Entre que nos move.

Alguns movimentos, ações, sensações, sobrevivências, projeções, percepções: um convite aberto ao "perder-se" pelo mundo.

| vento | encantar | murar | cascas | reagir | contato | produzir contato | embarulhar | equilibrar | parar | respirar | movimento-matéria do ser | estranhamento | alisar | escapar | forçar | transitar | deseducar | maquinar | afetar-se | desterritorializar | abandonar | terceira margem | produção do duplo | enrijecer | medo | útero urbano | restar | leveza | flexibilidade | fluxos | resistência | vaga-lumes | laços | quebrar des-engenhos | exteriores mentais | risco | corte | sobreviver | situações de jogo | 
transmutar | memória inconsciente | fugacidade | vazio | dobras | sangrar o espaço | ferir | correntes | cadeados | táticas de desvio | esvair-se | águas muradas | desenterrar | tropeçar | expurgar | coca-cola | tênis | arrastar | cobrir | proteger | pensamento lamacento | enclausurar | deitar | produzir vibrações | jornal | comunicar | descalçar | vaso | palmilha | fragmento | dar nós | falas emboladas | encruzilhadas | construir alianças | costurar fraturas | fios tênues | sorrir | mancar | subir | mediadores encantados | corpo terreiro | girar | arriscar | ler para o vazio | agachar | rastejar | voar | furar | deixar fluir | abrir encruzilhadas | cair | iluminação profana | rodar | olhar para cima | ouvir | estrangeiros | ler sem apoio | cuidar | cinzas | imitar estratos | anti-limites | sincopar | bambear | titubear | continuar | convocar energias $\mid$ fogo | escurecer $\mid$ relvar | vertigem | nuvens | libertar | sambar | 


\section{Referências bibliográficas}

A ABREU, M. O Rio de Janeiro no século XIX: da cidade colonial à cidade capitalista. In: Evolução Urbana do Rio de Janeiro. Rio de Janeiro: Instituto Pereira Passos, 2010, p. 35-59.

ARAGON, L. O camponês de Paris. São Paulo: Imago, 1996.

BENJAMIN, W. O Narrador: considerações sobre a obra de Nikolai Leskov. In: Walter Benjamin Obras escolhidas I: magia e técnica, arte e política. São Paulo: Editora Brasiliense, 2014, p. 213-240.

europeia. In: - O Surrealismo. O último instantâneo da inteligência $\begin{array}{ll}\text { europeia. In: } & \text { Walter Benjamin Obras escolhidas I: magia } \\ \text { e técnica, arte e política. São Paulo: Editora Brasiliense, 2014, p. 21-36 }\end{array}$

. Rua de Mão Única. Belo Horizonte: UFMG, 2009. Passagens. $1^{\text {a }}$ reimpressão. São Paulo: UFMG, 2007.

BRITO, F. D.; JACQUES, P. B. (Org.). Corpocidade debates, ações e articulações. Salvador: Edufba, 2010.

urbanos. Salvador: Edufba, 2017.

(Org.). Corpocidade gestos Le pas perdus. Paris: Gallimard, 1969.

BRETON, A. Nadja. São Paulo: Cosac Naify, 2007.

BRETON, Andre. Manifesto Surrealista. The Marxist internet archive. Transcrito por Alexandre Linares, 1924. Disponível em: < http://www.dominiopublico.gov.br/pesquisa/DetalheObraForm.do?select_a ction=\&co_obra=2320>. Acesso em: 14 ago. 2018

CARVALHO, F.R. A experiência. In: Experiência n2: realizada sobre uma procissão de Corpus-Christi. Uma possível teoria e uma experiência. Rio de Janeiro: Editora Nau, 2001. p. 11-50.

As ruínas do mundo. In: mundo. Campinas: Editora da Unicamp, 2014. p. 51-64. Os ossos do CARERI, F. Caminhar e Parar. São Paulo: Gustavo Gili, 2017.

Paulo: Gustavo Gili, 2013.

Walkscapes: o caminhar como prática estética. São

CERTEAU, M. Estratégias e táticas. In: cotidiano. Petrópolis: Editora Vozes, 1998. p. 97-103.

A invenção do 
DEBORD, G. A Sociedade do Espetáculo: comentários sobre a sociedade do espetáculo. Rio de Janeiro: Contraponto, 2017.

. Relatório sobre a construção de situações e sobre as condições de organização e de ação da tendência situacionista internacional. In: JACQUES, P.B. (Org.). Apologia da Deriva: Escritos Situacionistas sobre a cidade. Rio de Janeiro: Casa da Palavra, 2003, p. 43-59.

Teoria da Deriva. In: JACQUES, P.B. (Org.). Apologia da Deriva: Escritos Situacionistas sobre a cidade. Rio de Janeiro: Casa da Palavra, 2003, p. 87-91.

DELEUZE, G. Segunda Série de Paradoxos: Dos Efeitos de Superfície. In: 2011, p. 5-12. . Lógica do Sentido. São Paulo: Editora Perspectiva,

DELEUZE, G; GUATTARI, F. Mil platôs: capitalismo e esquizofrenia. Vol. 5. São Paulo: Editora 34, 2017.

As máquinas desejantes. In:

Imago, 1976. p. 15-71.

O Anti-Édipo. Rio de Janeiro: Editora

O que é a filosofia? São Paulo: Editora

34, 1992.

DELEUZE, G. O que é um dispositivo? Tradução de Wanderson Flor do Nascimento, . Disponível em:

<https://pt.scribd.com/doc/65715889/Deleuze-O-que-e-um-dispositivo>.

Acesso em 14 ago. 2018.

DIDI-HUBERMAN, G. Cascas. São Paulo: Editora 34, 2017.

Estranheza. In:

Quando as

imagens tomam posição: $\mathbf{O}$ olho da história I. Belo Horizonte: UFMG, 2017b. p. 64-70.

Infernos? In:

Sobrevivência

dos vaga-lumes. Belo Horizonte. UFMG, 2014, p.11-38.

DIDI-HUBERMAN, G. Remontar, Remontagem (do tempo). Revista Etincelle, Ircan, Centro pompidou traduzido por Milene Migliano, 2016, Caderno de leituras n. 47. Disponível em: www.chaodafeira.com. Acesso em: 14 ago. 2018.

DRUMMOND, W; JACQUES, P. B. (Org.). Memória Narração História: Experiências metodológicas para compreensão da complexidade da cidade contemporânea. Salvador: Edufba, 2015. 
FOUCAULT, M. Sobre a História da Sexualidade. In:

Microfísica do Poder. Rio de Janeiro: Graal, 2000. p. 243-276.

FREUD, S. 1970. O Inquietante. In: História de uma neurose infantil: ("o homem dos lobos"), além do princípio do prazer e outros textos (1917-1920). Vol. 14. São Paulo: Companhia das letras, 2010. p. 329-376.

JACQUES, P.B. Introdução. In: Apologia da Deriva: Escritos Situacionistas sobre a cidade. Rio de Janeiro: Casa da Palavra, 2003. p.13-30.

Estética da ginga: a arquitetura das favelas através da obra de Hélio Oiticica. Rio de Janeiro: Casa da Palavra, 2003.

Elogio aos errantes. Salvador: Edufba, 2014.

- Montagem urbana: uma forma de conhecimento das cidades e do urbanismo. In: BRITTO, F.B; JACQUES, P.B. (Org.). Experiências metodológicas para compreensão e apreensão da cidade contemporânea IV. Memória Narração História. Salvador: Edufba, 2015. p. 47-83.

Pensar por Montagens. In: JACQUES, P.B; PEREIRA, M.S. (Org.). Nebulosas do Pensamento Urbanístico. Salvador: Edufba, 2018. p. 209-234.

LINS, A. J. P. S. Ferrovia e segregação espacial no subúrbio: Quintino Bocaiúva, Rio de Janeiro. In: OLIVEIRA, M.P; FERNANDES, N.N. (Orgs.). 150 anos de subúrbio carioca. Rio de Janeiro: Editora Eduff e Lamparina, 2010. p. 138-160.

MAZZURELLI, K. Sobre Marfins, Dentes, Ossos: uma breve introdução ao trabalho de Paulo Nazareth. In: Nazareth, P. Paulo Nazareth - Arte contemporânea. Rio de Janeiro: Editora Cobogó, 2012.

MELO, J. Caminhos e conversas de viagem. In: Nazareth, Paulo. Paulo Nazareth - Arte contemporânea. Rio de Janeiro: Editora Cobogó, 2012.

NAZARETH, P. In: Paulo Nazareth - Arte contemporânea. Rio de Janeiro: Editora Cobogó, 2012.

RIBEIRO, A. C. T. Dança dos Sentidos: na busca de alguns gestos. In: BRITO, F. D.; JACQUES, P. B. (Org.). Corpocidade debates, ações e articulações. Salvador: Edufba, 2010. p. 24-41.

MAGNAVITA, P. R. A cidade exige, conclama, exorta: construa seu corpo sem órgãos. In: BRITO, F. D.; JACQUES, P. B. (org.). Corpocidade debates, ações e articulações. Salvador: Edufba, 2010, p. 44-56 
ROSA, G. A terceira Margem do Rio. In: Ficção completa:

Volume II. Rio de Janeiro: Nova Aguilar, 1994. p. 409-413.

RUFINO, L.; SIMAS, L. A. Fogo no Mato: a ciência encantada das macumbas. Rio de Janeiro: Editora Mórula, 2018.

SMITHSON, R. A tour of the monuments of Passaic, New Jersey. In. Flam, J. (Ed.). Robert Smithson: the collected writings. Berkeley: University of California Press, 1996. p.68-74.

Uma sedimentação da mente: projetos de terra. In:

Ferreira, Gloria; Cotrim, Cecila. (Org.) Escritos de Artistas - anos 60/70. Rio de Janeiro: Jorge Zahar, 2006, p.182-197.

SOLÀ-MORALES, I. Territorios. Barcelona: Gustavo Gilli. 2002.

SOMMER, M. (Org.). Práticas contemporâneas do Mover-se. Rio de Janeiro: Editora Circuito, 2015.

TARKOVSKI, A. Stalker. Direção: Andrei Tarkovski. Roteiro: Andrei Tarkovski, Arkadi e Boris Strugatski. Direção de Arte: A Merkúlov. Intérpretes: Anatoli Solonitsyn, Alexandr Kaidanovski, Nicolái Grinko, Alissa Freindikh, Natasha Abramova. Fotografia: Aleksandr Kniajinski. Música: Eduard Artemiev, Ravel, Beethoven. Edição: Ludmila Feignova. Produção: Mosfilm. Continental Home Video. 1979. DVD (134 min).

VIDLER, A. The architectural uncanny. Cambrige: MIT Press, 1992.

VIDLER, A. Uma teoria sobre o estranhamento familiar. In: NESBITT, K. (Org.). Uma nova agenda para a arquitetura. Antologia teórica 19651995. São Paulo: Cosac Naify, 2015, p. 617-622.

ZOURABICHIVILI, F. O vocabulário de Deleuze. Traduzido por André Telles. Rio de Janeiro: Editora Relume-Dumará, 2004. 


\section{Anexo: outros fragmentos errantes}

Sobre equilíbrio. A presença é dura quando se olha de frente. É difícil olhar de frente, mas quando eu nasci me colocaram de frente. Um corpo duro. Corpo que se acostuma a ser assim. Séculos sendo assim. Mas inquieta a alma me imaginar sempre desta forma. Ficar ao seu lado e me dar conta de que tal dureza jamais será alcançada aqui, onde eu sinto as coisas. Nem quero, claro. Quero caminhar ao seu lado: buscar a falta, a ausência, o vazio, o que desequilibra. Buscar meu sonho de movimento, que é presença. Buscar, buscar, buscar.

Sobre cascas. Estou cercado de vento, rodas, motores, pedra, concreto. Caminhar entre isto. Turbilhão de forças. Insisto: caminhar entre isto. Arrastar forças e deixar-se levar pela força do vento. Arranhão. Dor silenciosa. Continuar a caminhar arranhado. $\mathrm{O}$ vento que leva o corpo, sussurra seus segredos e seca o sangue. De quantas cascas eu sou feito? Sou pele que sangra também? O vento que leva o corpo é amigo e seca o sangue. Quanto tempo demora para secar seu sangue? O meu vai com o vento.

Companheiro caminhante. Vem junto do ombro, se arrastando junto do ombro. Vira o olho e aparece. Como é longe pra vir até aqui! Você sabe disso... mas continue sério, ouvindo e absorvendo essa mensagem. Arrastando-se junto do ombro. Estranho. Eu sei que você ouve, tanto sei que às vezes você some, como uma resposta ao lamento da sua presença assustadoramente presente. Que some e depois aparece, depois some de novo, depois aparece. Caminhar sério me cansa. Absorver as forças do entorno. Sumir. Aparecer.

Sobre encantamentos. A sua envergadura no espaço é grande. Enverga tanto que cai. Desmonta. Controle desmontado para dar conta do tempo que invade. Desviar desdobra o caminho, sabia? Toma o tempo, o tempo toma, toma o corpo, cadê você? Vento, medo e coluna arranhada. Está aqui. Parar. Respirar. Focar: pisa, caminha em ritmo sequenciado para achar uma fuga ou uma referência. Eu conhecia aquele desvio da torre de energia. Conhecia a propaganda de jogo de 
búzios inscrita nela. Ela aparecia de vez em quando. Era encantada. Caminhar encantado, caminhar no encantado.

O que é ter/ser uma sombra? Arrastão. Do lado de dentro, colado nele vi o arrastão: controle, secção, corte, separação, proteção. De quem? Da Luz. Arrastão da memória na sola dos pés. Caminhar. Medo. Caminhar na sombra. Entrar no arrastão e sair da luz. Lembro da passagem com cheiro de mijo aqui embaixo. Caminhar, caminhar, caminhar. Naturalizar a prisão. Arrastar a prisão no corpo. Flutuar. Sumir com os muros que sumiram. Flutuar, caminhar, soltar, soltar, soltar no vento que invade o nariz. Rebelião da prisão no corpo. Socar o muro.

Sobrepondo concretos. Estrato do estranho. Arqueologia do controle. Vem por cima, depois por cima e outro por cima, pra ta(m)par. Não pode ver. Não pode passar. Não pode cruzar. Não pode quebrar. Não pode. Não, não, não. Aí vem um por cima do outro. As mãos vêm pelo lado disso sentir o tempo, a temperatura. Sentir caminhando, tocando muro e chão. Onde isso vai parar? Onde eu vou parar? Estrato do controle infinito que dá calor nas mãos. Correr. Aumentar o fogo e queimar o estrato, misturá-lo. Mistura alquímica de concreto, mãos e memória. Esquecer o controle.

Sobrepondo tijolos. Intimidade. Fundos. Caminhar lentamente. Intimidade outra: virada de costas. Fundos lentos; costas como cestos de vime cheios de insegurança, fragilidades e medos guardados. Intimidade outra: exposta e murada. Suor escorre nas costas muradas de pele e expostas ao arrepio do vento. Suor seca. Vento leva. Leva, leva, lava de vento. Continuar a caminhar.

Sobrepondo pedras. Ódio ao capricho: tentar desencaixar uma unidade da outra. Desencaixar andando sobre os buracos, sobre as faltas. Faltas, faltas, faltas imensas. Ódio a esse capricho. Caminhar pulando. Joelho. Entortar o joelho caminhando. Desrebuscar o corpo. Medo. Medo. Descolocar os pés, um após o outro. Descolocar para seguir na superfície. Para que serve colocar uma ao lado, em cima, encaixada na outra? Colocar eterno de controle. Ódio ao capricho para controlar, erguer. Caminhar, sentir a superfície desregulada. Desregular os corpos, desregular o pensamento. Desregular o pensamento. 
Basculantes de alumínio: janelas nebulosas. Embaçar a vista. Embaçar a visão. Caminhar com vontade de comer. Banho. Condicionador. Será? Fome. Ovo? Boca que sente falta de alguma coisa. Sem nome. Corpo que sente falta de vazio. Chuveiro? Fome. Embaçar o estômago. Embaçar a vista. Enxergar. Desejo de comer. Caminhar.

Perder-se. Flagrar uma presença monumental. Esticar o braço e colocar a palma da mão no muro. Olhar pra cima e ver o céu. Olhar para o lado e ver o muro. Olhar para o outro e ver o muro. Olhar para trás e ver os trilhos. Caminhar. Medo. Caminhar. Olhar para frente. Conheço estas pedras. Medo. Acho que conheço estas pedras. Medo. Sentir o vento. Seguir o vento.

Um celular e um capuz. Conectar mundos invisíveis. Acessá-los. A fala e a não fala da boca. Aproximar a boca do celular. Avisar. Ação de conexão. Estado de alerta, ou de brincadeira. Medo. Medo. Medo. Medo. Tecnologia: servir à possibilidade de saltear na realidade, saltear da realidade, saltear entre tempos, saltear entre coisas e saltear entre situações. Medo no pulmão. Outro que esconde, cobre formas, deixa rastros de feições no rosto. Sobreviver. Produzir rastros. Provocar incertezas. Provocar, provocar, provocar o corpo. Correr. Corro. Medo. Tropeço. Medo e corrida. Perigo.

Sobre cegueira. Abertura de mundo. Mãos, ar, pés, pedras, terra. Ar, ar, ar nas narinas, no pulmão. Tentar caminhar. Parar. Sentir as energias pulsarem no corpo. Tentar caminhar. Ombros trêmulos. Caminhar devagar, sentir o vento chegar. Abrir os caminhos. Maravilha de libertação.

Sobre platôs. Tilintar das pedras toma o silêncio. Pisar, pisar de novo, pisar de novo. Lembrar da precisão geométrica dos pés. Carne que ganha vida ao tocar este caminho. Pedra. Sente, entorta, força e torna. Fazer circular o sangue. Passo a passo. Do passo a carne viva junto à pedreira desmontada em miúdos no chão. Ritmo tilintado é o ritmo do coração. Voltar a bater. Rebater. Refazer. Refazer-se a cada som, deixar ecoar as intensidades diferentes. Pedras deitadas. Quintal da Ana. Pisar a carne emadeirada que as atravessam. Inchar, espalhar e continuar 
engordando essas peças, não aquelas. Perna bamba. Joelho. Cuidado. Mãos naquelas que parecem tranquilas em seus pesos. Jogar o peso do corpo para cima delas. Conforto. Finalmente conforto.

A toca da ratazana. Pisar nas certezas, certezas, certezas. Rua atravessada por certezas. Carros que correm, casas que abrigam, calçadas que sustentam, muros que controlam. Coisas para outras. Rua de coisas iluminadas por certezas. Cansaço. Caminhar cansado. Caminhar lentamente. Aproveitar o ritmo lento. Pisar devagar. Impacto de motor na orelha. Fumaça. Aceleração. Acelerar a ação. Correr cansado. Parar. O caminhão me pegou de surpresa. Os ratos mudam a dinâmica da rua: não pisam, deslizam e se entocam. Entocar, entocar o corpo num bar. Ver uma janela, pular a janela.

Arame farpado. Possibilidade de se cortar. Evitar. Evitar. Levitar. Será que dá? Entorta o corpo como fruto de maculação divinatória. Entorta. Violar a unidade. Abrir a pele ao afeto. Desunificar o corpo. Desconjuntar. Desconjuntar o inviolável. É mais alto. Corpo que segue emaranhado e aberto ao corte da farpa. Ansiedade na barriga. Dor de barriga. Achar os pontos do corpo que cortam o espaço, suas angulações de corte, suas ferrugens, seus tempos. Fisgar o espaço, absorver seu sangue na pele.

Cerceamento: um colete amarelo. Caminhar no cinza. Muros cinzas. Ver amarelo. Aqui pode passar, ele deixa. Ele oficializa. Trem: agachar e explodir. Correr para o controle institucionalizado no furo. Estranho. Todos vão passar, eu também. Misturar, vem de lá, vem de cá. Cruzar. Olhares, vozes: barba grande. Diminuir o ritmo, cruzar andando.

Linhas de ferro. Caminhar e não caber na estrutura da retidão. Perceber a movimentação do corpo. Corpo que movimenta. Desequilibrar no trilho do trem. Escorregar o pé. Não ficar por muito tempo. Medo de cair. Pé. Trilho. Pé-trilho. Trilho do pé. Sair do trilho. Corpo que sai do trilho. Ao lado do trilho. (Des)trilhar ao lado, mesmo sem comungar em tempo, sem comungar em corpo. Trilho que se abre em dois, que se abre em três, que se abre em dez, que se abre em campo. 
Chão. Pedaço de trilho. Pedras. Cama. Não caber na retidão da linha e restar no chão. Deixar nascer relva por cima. Esperança. Continuar.

O (des)conforto das roupas íntimas. Irreconhecíveis. Sujas, emboladas, rasgadas, no entanto exercendo sua potência de emaranhamento de tempos. Nesse emaranhado, parecem confortáveis. Roupa como aglomerado temporal, que insistimos em querer eliminar. Deixar ir, descartar, misturar, sujar, virar na terra, virar no esgoto, perder suas funções de cobertura, virar estrato. Entrega dos corpos ao (des)conforto. Aqui uma fisgada por baixo da calça me lembra o tempo das coisas na contemporaneidade. Mesmo com a fisgada, preciso continuar.

Casa e carrinhos de rolimã. Fragmentos remontados. Casa enquanto deslocamento e corpo enquanto dispositivo de (re)(1)ação. Corpocasa, se assim posso chamar. Abertura para outros corpos, corpos do intervalo, do arranjo, do improviso. Encaixe de peças que não se encaixam, testes de materialidades, porosidades e eficiências. Pega, testa e larga. Teste. Aprender a deixar os pedaços irem. Ir deixando a casa para trás, a todo tempo.

Madeiras e o coletivo. Apoiar, tocar, desviar, como se tudo aquilo fosse planejado. Muitas vezes é, outras não. Sempre juntas. Guardar posições e tempos diversos. Sentir o tempo dos tempos. Sedimentar, romper e ouvir os tempos. Coração que agrupa memória. Coração que não é unidade, mas agrupamento de singularidades mneumônicas e sangue. Limo, veios, nós, cortes. Vávulas. Outras válvulas. Troca de sangue. Escavações, buracos, vegetação. Entrar e sair distinta e livremente. Tesão de correr. Correr junto: dobrar e redobrar o corpo no vazio. Correr e dobrar junto.

Jogos de esquina. Aprender a trapacear. Trapacear e gargalhar. Ela quase caiu. Estava cheia de bolsa. Corpo que balança alcança o mais vazio. Caminhar com a garganta cheia de alegria de vazio. Pés atrás de pés, jogar o corpo. Mão que vira pé. Estrela. Capoeira. Trapaça na calçada. Trapacear a calçada que espera pés. Gargalhar. Voltar a caminhar. Olhares. Bolsas. Concentração. Lá, mas agora aqui. Caminhar, entrar, virar. Terra e pedra e uma mesa. Quatro homens juntos gargalhando. Cartas. Trapaça. Trapaçar. Ultrapassar. Graça. 
Uniformes, mochilas e silêncio. O caminhar como forma de chegar. Elas vão de uniforme para a escola, carregam mochilas e estão em silencio. Uniforme, mochilas, silêncio. Três elementos, muitos mundos por dentro. Corpos andando. Ritmo sincronizado como se fossem para um mesmo lugar, mas quantos lugares cabem neste caminho se infinitos mundos cabem em cada corpo? Rosas, Roxas e Azuis: mochilas: extensões do corpo. Mochilas: caminhos antiuniformes. Silêncio como cúmplice.

Telhados: a consagração do provisório. Bico de amianto afiado aponta para o céu. Terra, amianto, com terra e amianto e terra. Terra e amianto abaixo. Ondas parciais pelo meio. Recolocar funções. Titubear sua forma. Grito de misericórdia de suas funções. Meus pés tão aqui? Olhos que vêm ondas, ondas, Miralles, ondas. Ver. Flutuar e ver sopreposições. Abertura processual da obra. Canteiro como local de afeto. Quebras e fragmentos expostos, externados, externando novos caminhos de construção. Dentro, fora, no meio. Dobras. Provisoriedade.

Escorrega telúrico. Sondar, escutar, sentir, acolher as diversidades existentes no solo, medir os níveis de estabilidade da terra. Pensar ao contrário. Sondar, escutar, sentir, acolher os níveis de instabilidade, de descontrole, de imprevisibilidade, de diferença e repetição que o solo possui. Deslocamento, força da gravidade. Caminhar com potência telúrica. Meu corpo é barro, é terra. Desvio.

Chuva e cigarros. Caminhar e ver os vagalumes aparecerem. Sem formas, sem desejos claros. Mercúrio. Circular entre luz e sombra. Flutuar com muita sombra. Sentir a respiração. Água escorre no olho. Nas mãos. Sentir no nariz fumaças, depois luzes e chamas. Fumaças que chamam. Fumaças que avisam. Num sei. Continuo? Continua. Continuar a caminhar. Lentamente como elas. Tão parte da natureza e tão deslocadas de seus chamados. Insistir em flutuar. Insistir em flanar. Insistir na mágica dos avisos. Drama e potências contemporâneos.

Ferro concretado e cabanas. Marcas do tempo, acolhimento crescente. Abrigo torto, cheio de furos, mas que abrigo não tem furos? Falo desmontado, falo torto e enferrujado. Abaixo o menir! Acima a ponte inclinada para subir e pular, ou para 
entrar em baixo e sentar. Ainda há lugares que, mesmo em toda sua transitoriedade, pulsam uma ideia de acolhimento. Acolhimento contemporâneo do afeto, do devir, da transformação incessante das coisas em outras. Como cabanas de tecido que mudam de acordo com a intensidade do vento.

Varais. Estar aberto às intempéries, estar preso à linha da vida.

Cinzas ao vento. Tropeçar na alça de ferro fincada num buraco de concreto. Cair com as mãos nas pedras. Levantar a cabeça. Defumador? Cheiro de fumaça. Ansiedade. Querer descobrir de onde vem tal operação. Onde estou? Não conhecer o lugar da ação, mas sentir sua força através do cheiro. Cheiro e ardência nos olhos. Cinzas ao vento que se dispersam no ar, mas dão os sinais. Apontar os rastros de transformação. Voa, voo, venta, vento, eu vento, eu no vento. Cinzas, eu no vento espalhando notícias, sonhos e tempos de sofás, colchões e folhas encantadas. Espalhar.

Sobre esvair-se e fogueiras. Cobre, abafa, ascende, expande, transforma. Rituais de transformação bruta que conhecem as matas fáceis, esparsas. Suas marcas, seus índices, seus rastros aumentam a complexidade do espaço-tempo na medida em que nos transportam para lugares dos primórdios. Em paralelo nos lembram a necessidade fundamental de entender o que na verdade podemos também ser, enquanto corpo: cinza no vento.

Sobre incorporações. Medo e desejo de correr. Corre com a mão, com o olho, com o pulmão, mas o pé fica. Ele está vindo. Forças que vêm do campo: conjunto de afetos, conjunto de corpos. Medo. E vieram, tomaram e desmontaram os pés. Não pode correr, mas o pulmão corre. Não pode correr, mas o olho corre. Não pode correr, mas o coração corre. Agora pode caminhar. Caminhar como reação aos afetos que se movem dentro deste terreno. Afetos. Enunciações. Enunciações desta topia incontestável, meu corpo, em direção às utopias, os não-topos deste campo. O contrário também é verdadeiro. Pele que sente outro corpo. Pele que incorpora. Pele que expande. Inscrições no corpo do fluxo da vida. Medo. 
Passadas desritmadas. Desfazer o samba. Surdo. Surdo um. Desfazer. Desfazer a passada. Tirar o pé do chão, apoiar a mão. Chutar a pedra. Passar a perna. Pular. Ritmo de outro. Cuíca. Chora com lenço. Chora o rito mais alto. Continuar. Sorrir, Continuar.

Sopro do trovão. Silêncio, silêncio, silêncio. Ecoa de longe o som da brisa, que continua brisa, que vira vento, que vira vento, que vira breu. Medo ensurdecedor. Os olhos sentem no horizonte o sopro do que está prestes a chegar. Dá pra sentir a força, mesmo ainda de longe. Anúncio conhecido. Desconhecer meu corpo. Desconhecer o anúncio. Assombro e ânsia pelo porvir.

Sobre relâmpagos. Pular o muro. Limbo da vida, limbo do corpo, entrada a partir do choque. Medo. Força que passa, imprevisível e toma o corpo. Cresce da cabeça e se expande sem ritmo definido até os pés. Clarão de som e ferro em busca do chão; Enfim, Liberdade.

Suor nas mãos. Procurar o vazio, invadir o vazio. Primeira tática: encostar nas coisas para pegar impulso e levar a poeira no corpo. Segunda tática: improvisar/adaptar o corpo para invadir o vazio entre as coisas. Lançar o corpo no vazio e levar os muros no suor. Caminhar invadindo o vazio. Construir o corpo a partir das continuidades. Improvisar e continuar. Adaptar. Sentir as texturas dos cheios no suor. Sentir o vazio imprevisível no corpo. Continuar, continuar, continuar.

Sobre escuridão e acolhimento. $\mathrm{O}$ buraco é baixo. Medo. Para passar tem que se arrastar no chão. Peito no chão, peito que arrasta chão para o vazio. Caminhar lentamente e sorrir. Alegria. Casa no vazio, no deslocamento entre a mata. Silêncio, paz, brisa leve. Caminhar lentamente e pegar uma flor. Energia da planta gasta para se abrir ao vazio com seu sorriso mais forte. Caminhar entre a mata, caminhar arrastando o chão no peito; caminhar arrastando o medo, o chão no peito e o abrigo. Sorriso. Flor.

Invasões: algumas formas. Ele veio de casaco e mochila. Eles vinham de carro. Ele vinha de bicicleta. Ela vem com uma sacola. Elas vêm de mochilas nas costas 
e de carrinho. Eles vêm sem nada nas mãos. Objetivos, finalidades. Não, não. Eu não. Eu sigo. Eu desvio. Eu pulo. Eu quebro. Antiobjetivo. Escutar os fluxos. Seguir os fluxos. Pertencer aos fluxos. Arrastar a cidade no corpo. Invadir o vazio.

Na saída do ladrão. Como eu vim parar aqui? Loja de concertos mecânicos. Caminhar no calor. Ficar sem sombras, caminhar no sol, exposto. Contravento. Contraventa. Catavento. Travar o vento dos carros. Caminhar contra. Ombro de ferro. Muro baixo. Apoia, arranha o joelho e o peito. Sobe. Vento livre. Estrada aberta. Suor na cara o vento seca. Respirar. Sentar, pisar no cano e seguir. Caixa d’água. Não, não. Sorriso. Sombra. Caminhar. Alívio.

Reverências: abrir-se para o desconhecido. Falo erguido. Caminhar do falo. Caminhar falando. Falo ereto. Caminhar ereto. Ele corre ereto, deseja o território. Caminhar sem correr. Calma. Para passar tem que abaixar. Abaixar o tronco. Reverenciar o desconhecido. Medo. Tomar a benção do desconhecido. A benção! A benção! Tem que ajoelhar? Não. Caminhar, abaixar e entrar no desconhecido. Continuar.

Vácuo. Agachar na relva. Esperar. Ele está vindo. Respirar pelo nariz. Respirar pela coxa e sustentar. Apoiar a mão. Pertopertoperto, colado. Espremer o corpo contra o muro. Sufocar o corpo. Entrar no muro, sentir as costas no vento dos carros. Costas descoladas do corpo, atravessadas e coladas do outro lado do muro até ele terminar de passar. Corpo que fura o muro por força de sobrevivência. Preso e solto pela pressão. Agachar. Soltar os braços. Respirar. Quero água. Caminhar.

Monte no canto. Acertar o passo. Zumbido. Zumbido de carro. Barulho que treme a pele. Passar a loja, a casa, o bar, o muro. Parar, olhar e correr, subir, escorregar, sentar, apoiar, pular. Tem mais rato? Tem. Perigo. Trem: agachar e explodir. Respirar. Caminhar em paz. Ar, ar, ar.

Sobre trincheiras. Tênis apertado para continuar. Dor. Proteger os pés da dor, caminhar mais rápido. Pegar o vento, colocar nos pés. Tirar o peso. Pesa-cabeça. Pesa-ombro. Peso do vento nos pés. Parar. É calmo aqui. Será que tem água? 
Continuar. Caminhar. Trovão nos trilhos. Caminhar devagar. Estouro. Relâmpago. Passar pelo buraco na altura do joelho. Levar o susto, o peso para dentro do buraco. Levantar joelho passar a perna passando pela terra, passando pelos sacos. Estrume de cavalo. Energia de choque que vem da coluna. Azeda e intensa. Incorporar pela coluna. Jogar as pernas para frente. Aqui tem veneno de rato? Como pode? Pode, pode sim. Pode agir, pode romper a barreira. Caminhar rápido. Cabeça leve.

Ventos, anarquia e desmoronamentos. Desandar o caminho. Parar. Onde eu deixei meu celular? Medo. Procurar no bolso. Achar. Alívio. Caminhar, caminhar, caminhar. Trem: sem explosão. Corpo preparado para explosões. Peito aberto chamando o vazio. Caminhar, descaminhar, correr. Corrida: descaminhada do corpo em busca do desmoronamento do cheio. E desmorona mesmo. Desmorona o controle. Desmorona o concreto. Desmoronar para libertar e expor o tempo das coisas.

Frestas. Apertar, refazer as dimensões do tronco para passar. Alívio com a proximidade das coisas. Passar a cabeça. Alívio. Perto o calor aumenta, acelera o fluxo. Aperto. Aperto. Aperto no cruzo. Movimento apertado, rápido, acelerado. Pegar impulso para continuar. Cair em um pé só. Pular num pé só e gargalhar. 